\title{
Tire-Derived Geo-Cylinders and Polymer Products for Enhancing the Properties of Base/Sub base Materials in Pavement Systems
}

Justin Scott Smith

Structural Engineering Institute Graduate Student Chapter at WVU, jsmith41@mix.wvu.edu

Follow this and additional works at: https://researchrepository.wvu.edu/etd

Part of the Civil Engineering Commons, Construction Engineering and Management Commons, Geotechnical Engineering Commons, Structural Engineering Commons, and the Transportation

Engineering Commons

\section{Recommended Citation}

Smith, Justin Scott, "Tire-Derived Geo-Cylinders and Polymer Products for Enhancing the Properties of Base/Sub base Materials in Pavement Systems" (2018). Graduate Theses, Dissertations, and Problem Reports. 3681.

https://researchrepository.wvu.edu/etd/3681

This Thesis is protected by copyright and/or related rights. It has been brought to you by the The Research Repository @ WVU with permission from the rights-holder(s). You are free to use this Thesis in any way that is permitted by the copyright and related rights legislation that applies to your use. For other uses you must obtain permission from the rights-holder(s) directly, unless additional rights are indicated by a Creative Commons license in the record and/ or on the work itself. This Thesis has been accepted for inclusion in WVU Graduate Theses, Dissertations, and Problem Reports collection by an authorized administrator of The Research Repository @ WVU. For more information, please contact researchrepository@mail.wvu.edu. 


\title{
Tire-Derived Geo-Cylinders and Polymer Products for Enhancing the Properties of Base/Sub base Materials in Pavement Systems
}

\author{
Justin Smith \\ Thesis submitted to the \\ Benjamin M. Statler College of Engineering and Mineral Resources \\ at \\ West Virginia University \\ in partial fulfillment of the requirements \\ for the degree of \\ Master of Science \\ in \\ Civil and Environmental Engineering \\ PV Vijay, Ph.D., Chair \\ Radhey Sharma, Ph.D. \\ Gary Winn, Ph.D. \\ Department of Civil and Environmental Engineering
}

Morgantown, WV

2018

Keywords: base/sub base, geoweb, geogrid, mechanical concrete, confinement Copyright 2018 Justin Smith 


\title{
ABSTRACT \\ Tire-Derived Geo-Cylinders and Polymer Products for Enhancing the Properties of Base/Sub base Materials in Pavement Systems
}

\author{
Justin Smith
}

As a critical part of the transportation network, pavements offer a safe means for vehicular traffic. Pavements are subjected to many forms of stress during their service life, and they are susceptible to environment related cracking and failures. Failures can be attributed to poor subgrade, freezethaw variations, and fatigue under repetitive axle loadings. Reinforcement products such as tirederived geo-cylinders (TDGC) which make-up mechanical concrete and geo-polymers have been utilized in civil engineering practice, and this research aims to understand the potential life of tested pavement system components set at displacement limitations when reinforced with TDGCs and geo-polymers from exposure to various loading conditions.

In this study, research was performed on underlying materials of a pavement system, and this aided in examining suggested field implementation designs on the usage of tire-derived geo-cylinders (mechanical concrete) and geo-polymer cells filled with AASHTO \#57 aggregate to improve base/sub base strength. Alternative materials were examined when testing for confinement effects. The pavement reinforcement technologies strengthen the base/sub base and create a more stable platform for pavement systems through confinement effects. The mechanical concrete and geopolymers aid in distributing stresses from axle loads, and their use can lead to potential cost effectiveness, savings in material and labor, and sustainability. 


\section{ACKNOWLEDGEMENTS/DISCLAIMER}

I would like to express my sincere gratitude to my academic and research advisor, Dr. P.V. Vijay for his unstinted support and guidance during my Master of Science in Civil Engineering (MSCE) degree program. I would like to express my thanks to Dr. Gary Winn and Dr. Radhey Sharma, for serving as members of my AEC (Advisor and Examining Committee). I would also like to thank Mr. Samuel George Bonasso for his outstanding contributions and Mr. Jerry Nestor for his support in arranging lab testing, during my research. I would like to extend my appreciation to Justin Hayes of Foster Supply for material handling and Triad Engineering for the nuclear gauge testing.

Financial support from the WVDOH is greatly acknowledged. Input from Mr. Donny Williams and Mr. Mike Pumphrey during various stages of this work are appreciated. The views expressed in this report are that of the authors and WVDOH does not endorse any products and the views expressed herein are solely that of the authors.

I would like to take this opportunity to thank and dedicate this report to my family (Mr. Scott Smith, Mrs. Dina Smith, and my brother Mr. Lucas Smith) and friends for their support and encouragement throughout my journey in completing this study. 


\section{TABLE OF CONTENTS}

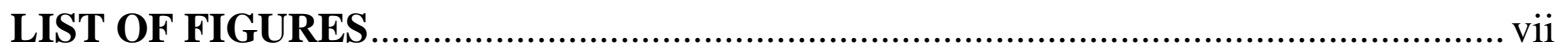

LIST OF TABLES ..............................................................................................

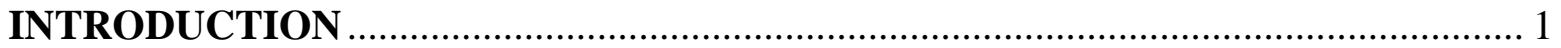

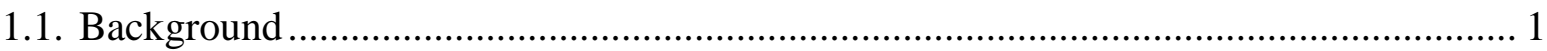

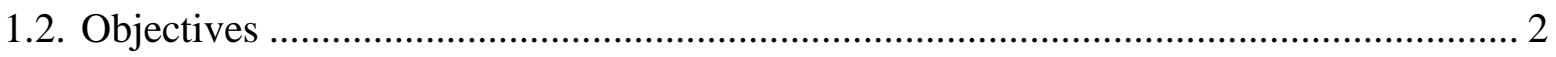

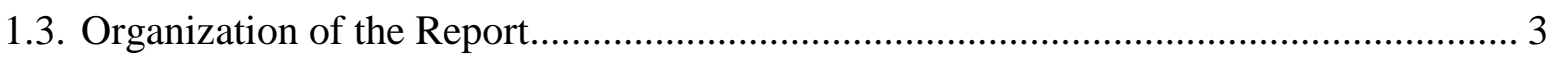

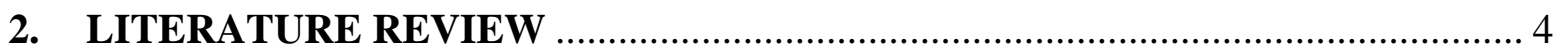

2.1. Base/Sub Base Enhancement Technologies ...................................................................... 4

2.1.1. An Investigation of the Interlayer Adhesion Strength between the Granular Base and Lightly Cemented Sub base and Its Influence on the Pavement Performance

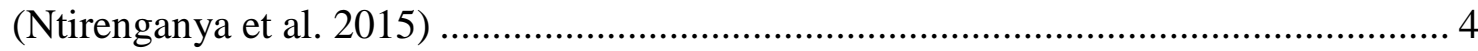

2.1.2. Behavior of Composite Pavement foundation Materials Subjected to Cyclic

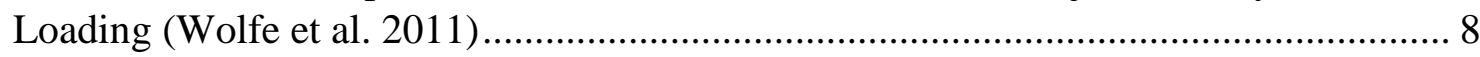

2.1.3. Mechanical Properties of Soil-RAP-Geopolymer for the Stabilization of Road Base/Sub Base (Adhikari et al. 2017) ....................................................................... 11

2.1.4. Evaluation of Structural Properties of Lime Stabilized Soils and Aggregates (Little, 1999) 12

2.1.5. Proposed Geoscientific Method for Determining Optimum Geosynthetics Embedment Location for Enhanced Performance of Geo-Structures (Mukabi, 2013) 15

2.1.6. A Study of Pavement Deformation Behavior of Geogrid-Reinforced Flexible Pavements Using Small Scale Accelerated Pavement Testing (Tang et al. 2011) ........ 17

2.1.7. Reinforcement of Pavements Over Expansive Clay Subgrades (Zornberg and Gupta, 2015) 20

2.1.8. Improvement of Pavement Foundation Response with Multi-Layers of Geocell

Reinforcement: Cyclic Plate Load Test (Khalaj et al. 2014)..... 23

2.1.9. Three Dimensional Cellular Confinement System Contribution to Structural Pavement Reinforcement (Kief and Rajagopal, 2008) 26

2.1.10. Advantages of Mechanical Concrete Road Over Conventional Road (Chakrey and

Pawar, 2015) 28

2.2. Conclusions. 31

3. MATERIALS AND TEST PROCEDURE …………...................................... 32

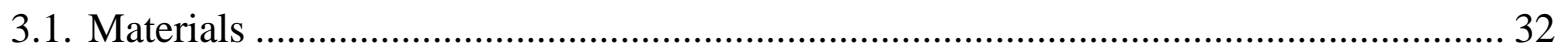

3.1.1. Lab Roadway Set-up ........................................................................................ 32

3.1.2 Laboratory Soil Testing ............................................................................................ 34 


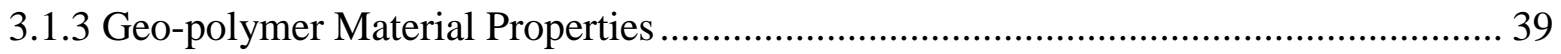

3.1.4 Recycled Tire (TDGC) Description and Properties ..................................................... 45

3.1.5 AASHTO \#57 Coarse Aggregate ........................................................................... 49

3.2. Laboratory Test Procedures ..................................................................................... 49

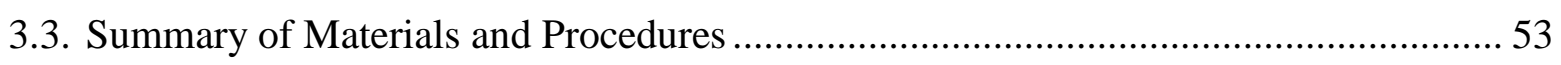

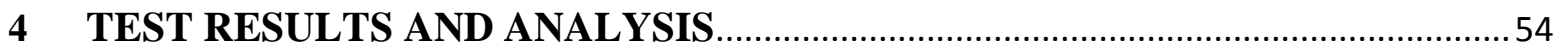

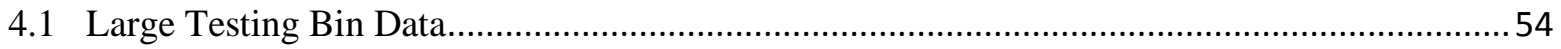

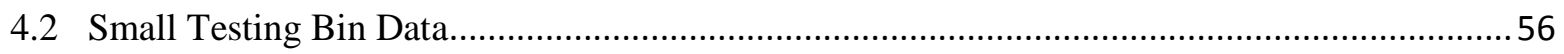

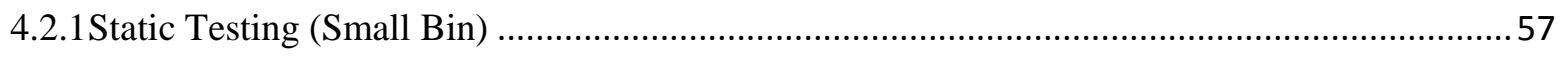

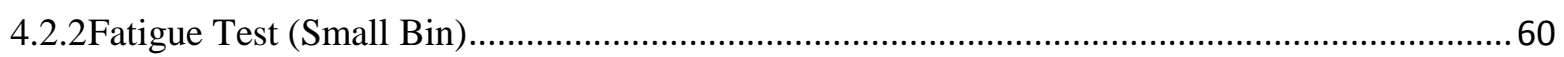

4.2.2.1 Low Load Range Case of 0.5-1.0 kip (1 million cycles) .................................................. 60

4.2.2.2 High Load Range Case of 1.0-4.0 kip (1 million cycles).................................................. 62

4.2.2.3 High Load Case (3 million cycles \& Post 3 million static tests)........................................64

4.2.2.4 Hot-Mix Asphalt (HMA) and Portland Cement Concrete (PCC) Slab Testing ...................66

4.3 Summary of Low Range and High Range Fatigue Load Tests .................................................6

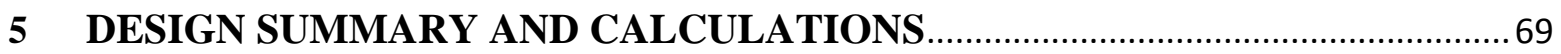

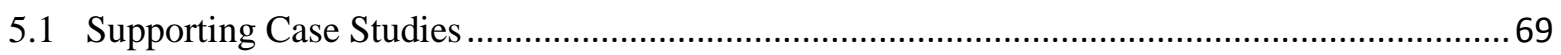

5.1.1Re-Construction of Major District Road in Nashik with StrataWeb, (Nashik, India) ...............69

5.1.2Doddridge County, WV Division of Highways Mechanical Concrete ${ }^{\circledR}$ Roadway Installation in

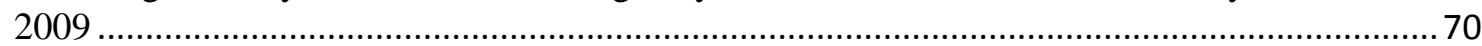

5.2 Flexible/Rigid Pavement Design Examples ..................................................................... 71

5.2.1 Proposed Flexible Pavement Design Example ..................................................................... 73

5.2.2Proposed Rigid Pavement Design Example …………………………………………...... 84

5.3 Cost Analysis for Conventional and Mechanical Concrete HMA Roadway Construction .........97

6 SUMMARY, CONCLUSIONS, AND FUTURE WORK …………………….........103

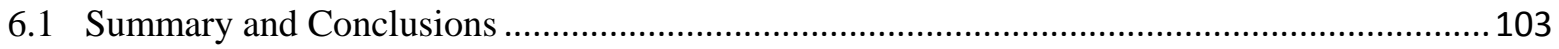

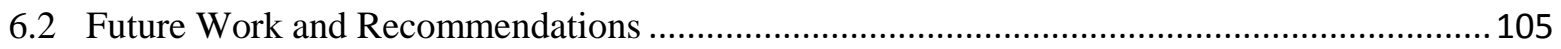

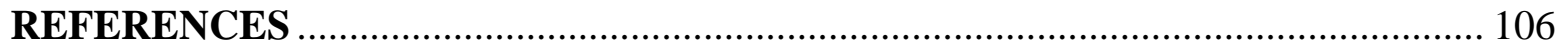

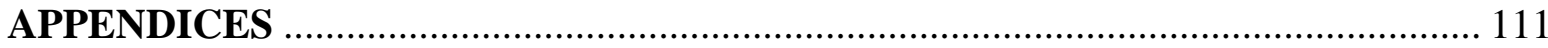

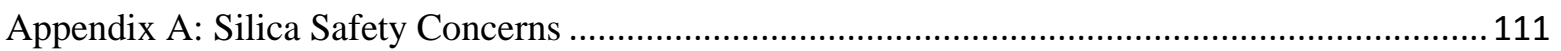

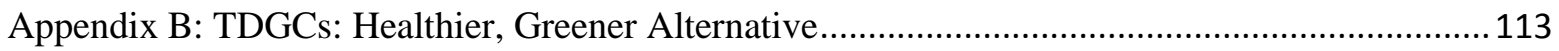

Appendix C: Confinement Testing TDGCs and Geo-Polymers.................................................. 114

C.1 TDGC and Geo-polymer Confinement Comparison and Bearing Capacity Calculation ..........114

C.1.1 Confinement Test Procedures …………………………………………………..... 115

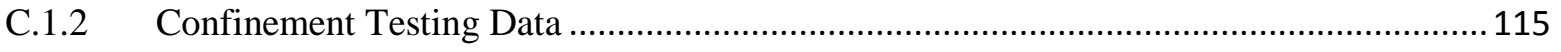


C.1.3 Bearing Capacity from Confinement ….................................................................. 117

C.1.4 Conclusion to TDGC and Geo-polymer Confinement Testing......................................120

C.2 Confinement Testing of Instrumented TDGC-S to Establish Poisson's Ratio ......................... 120

C.2.1 Confinement Testing Procedure for Instrumented TDGC-S ......................................... 120

C.2.2 Confinement Test Data for Instrumented TDGC-S .................................................... 121

C.2.3 Vertical and Horizontal Displacement Comparisons for AASHTO \#57 Aggregate, Sand,

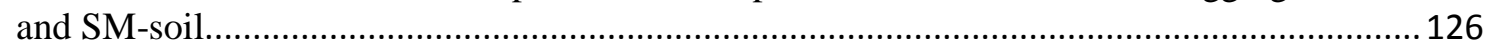

C.2.4 Instrumented Confinement Test Conclusions …........................................................ 129 


\section{LIST OF FIGURES}

FIGURE 1. 1 EXAMPLES OF PAVEMENT BASE/SUB BASE MATERIALS (A) GEO-WEB/CELLS (B) TIRE-DERIVED GEO-CYLINDERS

FIGURE 2. 1. CHARACTERIZATION OF RESEARCH MATERIALS (NTIRENGANYA ET AL. 2015) ............5

FIGURE 2. 2 PHOTOGRAPHIC ILLUSTRATION OF SPECIMEN SET UP IN THE SHEAR TRAC-III LOAD FRAME.

FIGURE 2.3 THE EFFECT OF THE NORMAL PRESSURE AND CTSB SURFACE CONDITION ON THE INTERLAYER SHEAR STRESS (NTIRENGANYA ET AL. 2015).

FIGURE 2. 4 SHEAR STRESS VERSUS HORIZONTAL DISPLACEMENT FOR INLAYER TESTS WITH 19MM MAXIMUM AGGREGATE SIZE(NTIRENGANYA ET AL. 2015) ...............................................

FIGURE 2. 5 SUMMARY OF RESILIENT MODULI FOR STABILIZED MATERIALS (WOLFE ET AL. 2011) DIAGRAM (ADHIKARI ET AL. 2017)...

FIGURE 2. 7 EFFECT OF VARIATION OF LOCATION OF GEOSYNTHETICS EMBEDMENT AND TYPE FOR; A) NON-STABILIZED SANDY BLACK COTTON SOIL (BCS) …............................................16

FIGURE 2. 8 SOIL SLURRY PUMPED UP ABOVE THE GEOGRID AND MIGRATED INTO THE AGGREGATES (TANG ET AL. 2011)

FIGURE 2.9 TYPICAL LONGITUDINAL CRACK DEVELOPED ON PAVEMENTS OVER EXPANSIVE CLAYS (ZORNBERG ET AL. 2015)....

FIGURE 2. 10 TYPICAL PAVEMENT CROSS-SECTION OF A LOW-VOLUME ROAD IN CENTRAL TEXAS USING REINFORCEMENT FOR MITIGATION OF CRACKS INDUCED BY EXPANSIVE SUBGRADES (ZORNBERG ET AL. 2015) .21

FIGURE 2. 11 SEPARATION OF LONGITUDINAL AND TRANSVERSE RIBS AT JUNCTIONS OF GEOGRID B AT LOCATION FM 1774 (ZORNBERG ET AL. 2015) .22

FIGURE 2. 12 SCHEMATIC CROSS-SECTION OF THE TEST SET-UP (NOT TO SCALE), "SPC 1", "SPC 2", AND "SPC 3" INDICATE THE LOCATION OF THREE SOIL PRESSURE CELLS (KHALAJ ET AL. 2014)

FIGURE 2. 13 COMPARISON BETWEEN UNREINFORCED AND IMPROVED GEOCELL-REINFORCED INSTALLATIONS FOR DIFFERENT LAYERS OF GEOCELLS (N) (KHALAJ ET AL. 2014) ...................25

FIGURE 2. 14 INSTALLATION AND INFILL OF THE GEOCELL (KIEF ET AL. 2008) ….............................27

FIGURE 2. 15 GRAPH OF LOADING RESULTS AS RECORDED BY PRESSURE CELLS DM2-DM3 (DYNAMIC-LEFT \& STATIC-RIGHT) (KIEF ET AL. 2008). .27

FIGURE 2. 16 (A) SHEAR PUNCHING WITH NO REINFORCEMENT (B) CONFINEMENT DECREASES PUNCHING AND INCREASES BEARING CAPACITY (KIEF ET AL. 2008)..........................................28

FIGURE 2. 17 GRAPHICAL REPRESENTATION OF ACTIVITY CHART (CHAKREY AND PAWAR, 2015)31

FIGURE 3. 1 LARGE BIN CONSTRUCTION (A) BUILT THE BIN'S FRAME (B) COVERING OF INTERIOR BIN SURFACE WITH POLYETHYLENE SHEETING (C) MOVING OF SOIL VIA SKID STEER (D) PLACEMENT OF SOIL IN THE TEST BIN (E) COMPACTED SOIL IN THREE 6-INCH LIFTS (F) PLACEMENT OF SEPARATION WOVEN GEOTEXTILE FABRIC ON THE SOIL SUBGRADE (G) PLACEMENT OF TDGCS (H) PLACEMENT OF AASHTO \#57 AGGREGATE AS INFILL FOR THE TDGCS (I) LEVELING OF THE AGGREGATE PRIOR TO TESTING.

FIGURE 3. 2 TEST BINS (A) LARGE (7'X12') BIN (B) SMALL (4'X6') BIN …….........................................34

FIGURE 3. 3 ATTERBERG LIMIT TESTING (A) MOISTURE CONTENT FOR SUBGRADE SOIL SPECIMEN USED IN THE TEST BINS (B) CASAGRANDE CUP AND FLAT GROOVING TOOL ............................35

FIGURE 3. 4 PLASTICITY CHART FOR IN-SITU SOIL, “A” LINE .............................................................35 
FIGURE 3. 5 SIEVE ANALYSIS LABORATORY DISPLAY OF EQUIPMENT (A) W.S. TYLER (RO-TAP) SIEVE SHAKER WITH SIEVES (B) MORTAR AND PESTLE ……......................................................

FIGURE 3. 6 GRAIN SIZE DISTRIBUTION OF SOIL USED IN LARGE AND SMALL TEST BIN TO REPRESENT PAVEMENT SUBGRADE 36

FIGURE 3. 7 SPECIFIC GRAVITY TESTING OF THE SUBGRADE SOIL SPECIMEN (A) PYCNOMETER USED FOR SOIL TESTING (B) AIR BEING WITHDRAWN FROM THE SOIL SPECIMEN....................37

FIGURE 3. 8 NUCLEAR GAUGE TESTING LOCATIONS (A) LARGE BIN TESTED LOCATIONS (B) SMALL BIN TESTED LOCATIONS....

$$
\text { SMALL BIN TESTED LOCATIONS....... }
$$

FIGURE 3. 9 NUCLEAR GAUGE TESTING OF SUBGRADE SOIL IN LARGE AND SMALL TEST BINS (A) OVERVIEW OF NUCLEAR GAUGE (B) NUCLEAR GAUGE TESTING IN THE CONSTRUCTED BINS

FIGURE 3. 10 SEPARATION WOVEN FABRIC (A) FABRIC USED ON TOP THE SUBGRADE FOR THE LARGE AND SMALL TEST BINS (B) A TDGC PLACED ON TOP OF THE SEPARATION WOVEN GEOTEXTILE FABRIC .38

FIGURE 3. 11 REINFORCEMENT WOVEN GEOTEXTILE UTILIZED FOR BASE/SUB BASE SUPPORT....40

FIGURE 3. 12 TENSILE TEST RESULTS OF THE WOVEN GEOTEXTILE SPECIMENS (A) LABORATORY SET-UP DURING TESTING (B) STRESS VS. STRAIN RELATIONSHIP.

FIGURE 3. 13 GEOGRID SPECIMEN UTILIZED FOR BASE/SUB BASE SUPPORT .....................................41

FIGURE 3. 14 TENSILE TEST RESULTS OF THE GEOGRID SPECIMENS (A) LABORATORY SET-UP DURING TESTING (B) STRESS VS. STRAIN RELATIONSHIP

FIGURE 3. 15 GEOWEB MATERIALS WITH VARYING DEPTHS (A) 6 INCH GEOWEB (B) 8 INCH GEOWEB (C) TENSILE TESTING OF HDPE GEOWEB STRIPS.

FIGURE 3. 16 TENSILE STRESS VS. STRAIN RELATIONSHIP FOR GEOWEB SPECIMENS ......................44

FIGURE 3.17 TIRE-DERIVED GEO-CYLINDERS (TDGC) (A) SMALL GEO-CYLINDER ( 16" DIAMETER), OR TDGC-S (B) LARGE GEO-CYLINDER ( 24” DIAMETER), OR TDGC . . .45

FIGURE 3. 18 TENSILE TESTING THE TDGC (A) TDGC CROSS SECTION (B) TDGC SPECIMEN IN TENSION . .46

FIGURE 3. 19 STRESS VS. STRAIN RELATIONSHIP FOR TENSILE TESTED TDGC SPECIMENS .............47

FIGURE 3. 20 TDGC SPECIMEN USED FOR COMPRESSION TESTING ......................................................47

FIGURE 3. 21 COMPRESSION TESTING OF THE TDGC SPECIMEN ……..................................................

FIGURE 3. 22 FAILED COMPRESSION SPECIMEN (A) TOP VIEW OF THE FAILED COMPRESSION TIRE SPECIMEN (B) BACK VIEW OF THE FAILED COMPRESSION SPECIMEN ...........................................48

FIGURE 3. 23 COMPRESSION STRESS VS. STRAIN GRAPH ..................................................................49

FIGURE 3. 24 SCHEMATIC OF TEST SET-UP FOR LARGE AND SMALL BIN TESTING WITH TIRE-

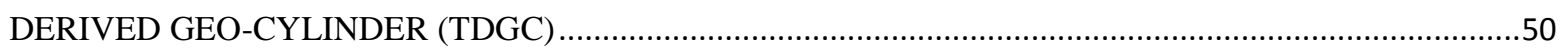

FIGURE 3. 25 PLATE SIZES (A) 24" (B) 15" (C) 12" (D) 10" X 20" ...........................................................52

FIGURE 3. 26 LOAD AREA FOR VEHICULAR TIRES (A) PLAN, OR TOP VIEW OF A LARGE TIRE (B) PLAN, OR TOP VIEW OF A DUALLY TIRE .............................................................................52

FIGURE 3. 27 REPRESENTATIVE PAVEMENT (ROADWAY) SECTION SET-UP (A) LARGE BIN, 7' X 12' (B) SMALL BIN, 4' X 6', . .53

FIGURE 4. 1 TDGC CONFIGURATIONS FOR LARGE BIN TESTING ......................................................54

FIGURE 4. 2 BASE/SUB BASE MODULI FOR 15” LOADING PLATE (LARGE TEST BIN)...........................56

FIGURE 4. 3 BASE/SUB BASE MODULI FOR 24” LOADING PLATE (LARGE TEST BIN)...........................56

FIGURE 4. 4 TESTING CONFIGURATIONS FOR STATIC TESTING IN THE SMALL BIN (A) FIVE SMALL TDGC-S OR 5 TDGC-S (B) OFFSET (C) TDGC (D) SMALL TDGC OR TDGC-S (E) TDGC-S FOOTPRINT USING 10"X20" PLATE (F) TDGC FOOTPRINT USING 10"X20" PLATE (G) GEOWEB - 6 INCH AND 8 INCH THICKNESS (H) WOVEN GEOTEXTILE (I) WOVEN GEOTEXTILE WITH GEOGRID (J) WOVEN GEOTEXTILE-GEOGRID-TDGC (K) BASE CONDITION WITH NO TDGC (L) SMALL TEST BIN 
FIGURE 4. 5 BASE/SUB BASE MODULI WITH RESPECT TO TIRE-DERIVED GEO-CYLINDER (MECHANICAL CONCRETE®) CONFIGURATIONS AND PLATE SIZES................................................58

FIGURE 4. 6 10”X 20" FOOTPRINT BASE/SUB BASE MODULI RESULT .......................................................59

FIGURE 4. 7 COMPARISON OF BASE/SUB BASE MODULI OF TDGCS AND GEOWEBS............................60

FIGURE 4. 8 (A) SMALL (4'X6') TEST BIN FATIGUE TESTS (B) DISPLACEMENTS FOR PAVEMENT SECTION WITH AND WITHOUT MECHANICAL CONCRETE SUBJECTED TO THE LOWER FATIGUE LOAD RANGE (0.5-1.0 KIP).

FIGURE 4. 9 INITIAL RESPONSES OF SPECIMENS EXPOSED TO LOADS OF 1-4 KIP...........................63

FIGURE 4. 10 GRAPHICAL TRENDS FOLLOWING INITIAL SETTLEMENT FOR LOADS OF 1-4 KIP.......64

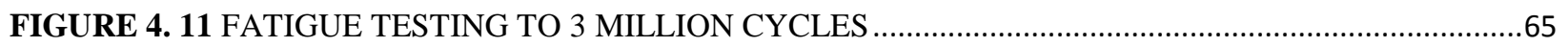

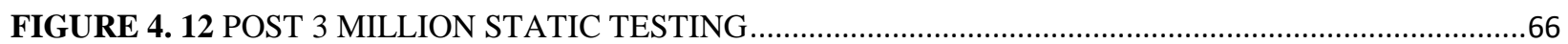

FIGURE 4. 13 ROADWAY SLABS (A) 11" CONCRETE (PCC) SLAB (B) 9" HOT-MIX ASPHALT (HMA)

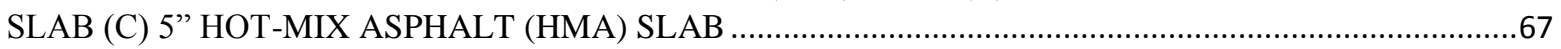

FIGURE 4. 14 DISPLACEMENTS OF EACH SLAB TYPE CORRESPONDING TO TDGC AND GEOWEB

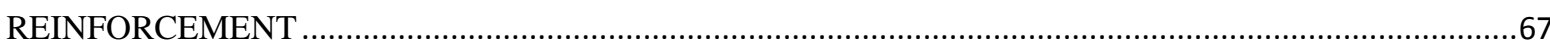

FIGURE 5. 1 (A) GEOWEB REINFORCED ROADWAY UNDER CONSTRUCTION (B) FINAL REINFORCED ROADWAY IN NASHIK, INDIA (STRATAWEB 2014)... . .70

FIGURE 5. 2 (A) MECHANICAL CONCRETE BASE IN DODDRIDGE COUNTY, WV (B) WEARING

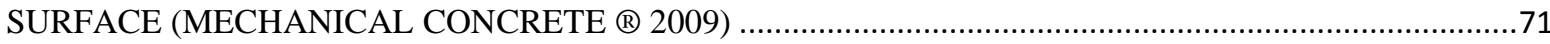

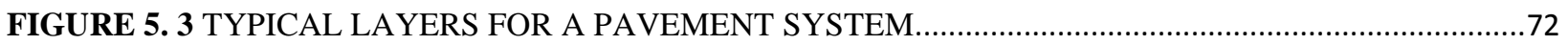

FIGURE 5. 4 STANDARD NORMAL VARIANT SELECTION FOR FLEXIBLE PAVEMENT .........................74

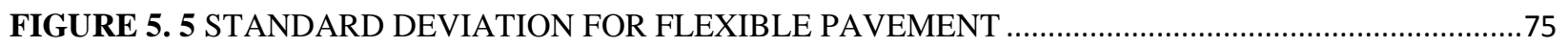

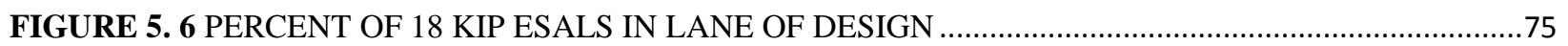

FIGURE 5. 7 QUALITY OF DRAINAGE ...........................................................................................

FIGURE 5. 8 MOISTURE EXPOSURE ON FLEXIBLE PAVEMENT STRUCTURES .......................................76

FIGURE 5.9 GRAPHS TO DETERMINE CBR AND STRUCTURAL COEFFICIENTS (A) VARIATION IN GRANULAR BASE LAYER COEFFICIENT $\left(\mathrm{A}_{2}\right)$ WITH VARIOUS BASE STRENGTH PARAMETERS

(B) VARIATION IN GRANULAR SUB BASE LAYER COEFFICIENT $\left(\mathrm{A}_{2}\right)$ WITH VARIOUS

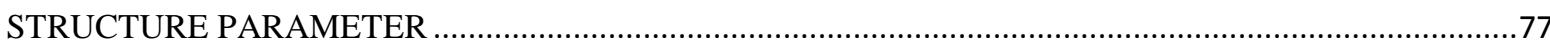

FIGURE 5. 10 CROSS SECTION OF STRUCTURAL NUMBER (SN) LAYERS AND DEPTHS IN A

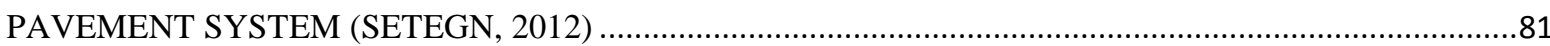

FIGURE 5. 11 NOMOGRAPH TO DETERMINE COMPOSITE MODULUS OF SUBGRADE REACTION $\left(\mathrm{K}_{\infty}\right)$

FIGURE 5. 12 LOSS OF SUPPORT VALUES FOR MATERIALS IN PAVEMENT DESIGN ………................87

FIGURE 5. 13 APPLICATION OF LS TO SOLVE FOR THE EFFECTIVE MODULUS OF SUBGRADE

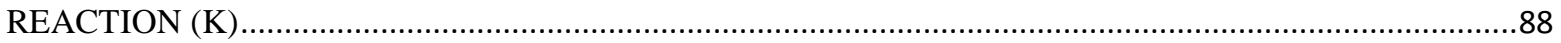

FIGURE 5. 14 STANDARD NORMAL VARIANT FOR RIGID PAVEMENT DESIGN ……...........................89

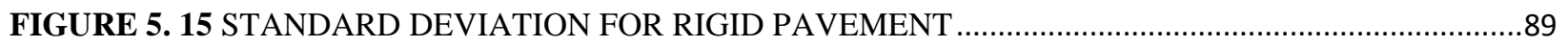

FIGURE 5. 16 MOISTURE EXPOSURE ON RIGID PAVEMENT STRUCTURES …...........................................90

FIGURE 5.17 DESIGN CHART FOR RIGID PAVEMENTS BASED ON USING MEAN VALUES FOR EACH

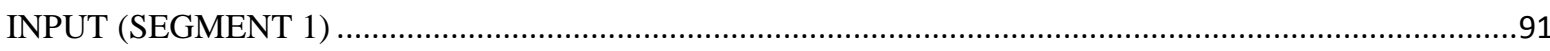

FIGURE 5. 18 DESIGN CHART FOR RIGID PAVEMENTS BASED ON USING MEAN VALUES FOR EACH INPUT (SEGMENT 2)

FIGURE C. 1 LOADING PLATES UTILIZED WHILE TESTING FOR CONFINEMENT (A) 11" DIAMETER PLATE (B) $40 \mathrm{IN}^{2}$ SURFACE AREA PLATE 114

FIGURE C. 2 INFILL MATERIALS (AASHTO \#57 AGGREGATE, SAND, SM-SOIL) FOR FILLING TDGCS AND GEOWEBS FOR CONFINEMENT TESTS. 
FIGURE C. 3 CONFINEMENT TESTING (A) 8" GEOWEB SINGLE CELL FILLED WITH SM-SOIL (B)

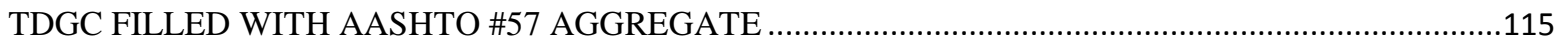

FIGURE C. 4 AASHTO \#57 CONFINEMENT TESTS FOR SINGLE CELLS OF GEOWEBS AND TDGCS ...116

FIGURE C. 5 SM-SOIL AND SAND CONFINEMENT TESTS …..............................................................116

FIGURE C. 6 CONFINEMENT TESTING OF INSTRUMENTED TDGC-S.................................................121

FIGURE C. 7 CONFINEMENT DATA ACQUISITION (A) TESTED INFILL MATERIALS (AASHTO \#57 AGGREGATE, SAND, SM-SOIL) (B) SET-UP TO OBTAIN MICRO-CONFINEMENT DATA ................121 FIGURE C. 8 VERTICAL AND HORIZONTAL DISPLACEMENTS IN THE FINAL LOAD CYCLE FOR EACH INFILL MATERIAL AT 10 KIPS OF LOAD

FIGURE C. 9 SM-SOIL COMPACTED FOLLOWING 10 KIP LOAD (A) TDGC-S TILTED VERTICALLY FOLLOWING TWO CYCLES OF 10 KIPS (B) DISPLAYS THE DISPLACEMENT WITHIN THE TDGC-S

FIGURE C. 10 VERTICAL AND HORIZONTAL DISPLACEMENTS IN THE FINAL TRIAL FOR EACH SPECIMEN AT 10 KIPS OF LOAD 128 .128 


\section{LIST OF TABLES}

TABLE 2. 1 SUMMARY OF METHODS USED FOR LABORATORY SOIL TESTS (WOLFE ET AL. 2011) .....9

TABLE 2. 2 SUMMARY OF DEVICES AND METHODS USED FOR IN SITU SOIL TESTING (WOLFE ET

AL. 2011)

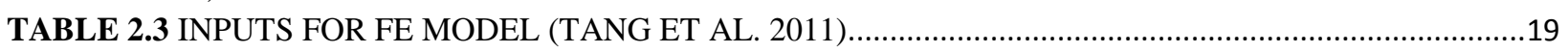

TABLE 2. 4 RELATIONSHIP BETWEEN SELECTED INDEX AND BENCH-SCALE PROPERTIES WITH SUBGRADE PERMANENT DEFORMATION FROM ACCELERATED TESTING (D: DIRECT, I:

INDIRECT, N: NO OBSERVED TREND) (TANG ET AL 2011.).

TABLE 2. 5 COMPARISON OF GEOGRID PROPERTIES WITH SPECIFICATIONS GIVEN BY TXDOT (ZORNBERG ET AL. 2015)

TABLE 2. 6 ACTIVITY SHEET FOR TIME COMPARISON IN CONSTRUCTION OF MCR AND CONVENTIONAL ROAD (IN HRS.) (CHAKREY AND PAWAR, 2015) .30

TABLE 3. 1 ATTERBERG LIMIT SUMMARY... .35

TABLE 3. 2 DENSITY AND MOISTURE DATA ACQUIRED FROM NUCLEAR GAUGE TESTING OF SOIL SPECIMEN IN LARGE BIN ... . .39

TABLE 3. 3 DENSITY AND MOISTURE DATA ACQUIRED FROM NUCLEAR GAUGE TESTING OF SOIL SPECIMEN IN SMALL BIN . .39

TABLE 3. 4 SUMMARY OF WOVEN GEOTEXTILE TENSION TESTED SPECIMENS ..................................40

TABLE 3. 5 SUMMARY OF WOVEN GEOTEXTILE TENSION TESTED SPECIMENS ...................................42

TABLE 3. 6 SUMMARY OF GEOWEB TENSION TESTED SPECIMENS.............................................................43

TABLE 3. 7 WOVEN FABRIC/ GEOGRID PROPERTIES …............................................................................4

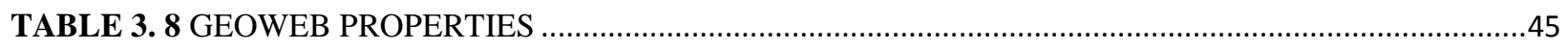

TABLE 3. 9 SUMMARY OF THE COUPON TENSION TEST SPECIMENS FROM A TDGC ...........................46

TABLE 3. 10 SUMMARY OF GEOWEB COMPRESSION TESTED SPECIMENS...............................................48

TABLE 3. 11 PHYSICAL AND MECHANICAL PROPERTIES OF TDGC SPECIMENS ..................................49

TABLE 4. 1 BASE/SUB BASE MODULUS OF THREE CONFIGURATIONS OF PAVEMENT REPRESENTATIVE SECTION (LARGE BIN) WITH THE USE OF 15” DIAMETER LOADING PLATE AND THEIR PERCENT INCREASE.

TABLE 4. 2 BASE/SUB BASE MODULUS OF THREE CONFIGURATIONS OF PAVEMENT REPRESENTATIVE SECTION (LARGE BIN) WITH THE USE OF 24” DIAMETER LOADING PLATE AND THEIR PERCENTAGE INCREASE. . .55

TABLE 4. 3 TDGC STATIC TEST SUMMARY IN THE SMALL (4'X6') BIN ......................................................58

TABLE 4. 4 TDGC AND GEOWEB (6” AND 8") STATIC TESTING SUMMARY …………............................60

TABLE 4. 5 DISPLACEMENT AT 1,000,000 CYCLES FOR SPECIMENS EXPOSED TO THE LOWER LOAD CASE

TABLE 4. 6 DISPLACEMENT AT 1,000,000 CYCLES FOR DIFFERENT BASE/SUB BASE CONFIGURATIONS UNDER HIGH LOAD RANGE (1.0-4.0) KIP OF FATIGUE LOAD. .62

TABLE 5. 1 PROPOSED SUMMARY FOR NO TDGC REINFORCEMENT ROAD BASE/SUB BASE ..............80

TABLE 5. 2 PROPOSED SUMMARY FOR TDGC REINFORCEMENT IN THE ROAD BASE/SUB BASE (34\% INCREASE IN PERFORMANCE APPLIED) MODULUS FROM STATIC TESTING)

TABLE 5. 3 CALCULATE THE ESTIMATED AVERAGE MODULUS OF RESILIENCE THROUGHOUT A YEAR

TABLE 5. 4 ACTIVITY SHEET FOR TIME COMPARISON IN CONSTRUCTION OF MECHANICAL CONCRETE ROAD (MCR) AND CONVENTIONAL ROAD (IN HRS.) ……........................................98

TABLE 5. 5 EQUIPMENT COSTS ASSOCIATED WITH A NON-TDGC REINFORCED HMA ROADWAY ...99 
TABLE 5. 6 LABOR COSTS FOR A NON-TDGC REINFORCED HMA ROADWAY...

TABLE 5. 7 MATERIAL COSTS FOR A NON-TDGC REINFORCED HMA ROADWAY.

TABLE 5.8 EQUIPMENT COSTS ASSOCIATED WITH A TDGC REINFORCED HMA ROADWAY ...........101

TABLE 5. 9 LABOR COSTS ASSOCIATED WITH A TDGC REINFORCED HMA ROADWAY ....................101

TABLE 5. 10 MATERIAL COSTS ASSOCIATED WITH A TDGC REINFORCED HMA ROADWAY ...........102

TABLE C. 1 BEARING CAPACITY CALCULATION 119

TABLE C. 2 HORIZONTAL DISPLACEMENT OF THE TDGC-S WHEN FILLED WITH (AASHTO \#57) COARSE AGGREGATE

TABLE C. 3 STRAIN CALCULATION IN THE X-DIRECTION (HOOP) FROM VERTICALLY APPLIED LOADS TO THE AGGREGATE WITHIN THE TDGC-S

TABLE C. 4 CALCULATION FOR STRAIN OBSERVED IN THE Z-DIRECTION (AXIAL) WITH AGGREGATE INFILL FOR A TDGC-S

TABLE C. 5 HORIZONTAL DISPLACEMENT OF THE TDGC-S WHEN FILLED WITH SAND 124

TABLE C. 6 STRAIN CALCULATION IN THE X-DIRECTION (HOOP) FROM VERTICALLY APPLIED LOADS TO THE SAND WITHIN THE TDGC-S

TABLE C. 7 CALCULATION FOR STRAIN OBSERVED IN THE Z-DIRECTION (AXIAL) WITH SAND INFILL FOR A TDGC-S. . .124

TABLE C. 8 HORIZONTAL DISPLACEMENT OF THE TDGC-S WHEN FILLED WITH SM-SOIL ...............125

TABLE C. 9 STRAIN CALCULATION IN THE X-DIRECTION (HOOP) FROM VERTICALLY APPLIED LOADS TO THE SM-SOIL WITHIN THE TDGC-S... 125

TABLE C. 10 CALCULATION FOR STRAIN OBSERVED IN THE Z-DIRECTION (AXIAL) WITH SM-SOIL INFILL FOR A TDGC-S.

TABLE C. 11 SUMMARY OF POISSON'S RATIOS FOR AASHTO \#57 AGGREGATE, SAND, AND SOIL CONFINED BY A TDGC-S

TABLE C. 12 VERTICAL TO HORIZONTAL DISPLACEMENT RATIOS AT 10 KIP 128

TABLE C. 13 VERTICAL TO HORIZONTAL DISPLACEMENT RATIOS AT 15 KIP 129 


\section{INTRODUCTION}

\subsection{Background}

Failures modes in flexible and rigid pavements are influenced by several factors such as insufficient compaction, moisture presence in the subgrade, high-intensity loads, freeze-thaw cycles, and various other in-situ and loading parameters. Constructability issues such as the lack of adherence to pavement construction procedures in terms of suggested minimum temperature ranges, inadequate compaction, and poorly managed construction rates can lead to pavement distress and failures. Various measures are taken to minimize the failure potential and improve the pavement performance. This report describes the evaluation of enhancement of pavement base/sub base properties through the use of different polymeric materials such as tire-derived geo-cylinders, woven geotextile fabrics, two-dimensional geogrids, and three-dimensional geo-webs/cells

Woven fabrics, two-dimensional geogrids, and three-dimensional geo-webs/cells are made of polymeric materials such as polypropylene and high-density polyethylene which are known to be effective in improving the base/sub base and subgrade properties (Figure 1.1). Mechanical Concrete ${ }^{\circledR}$ consisting of thin-walled cylinders filled with coarse aggregates have also been used in several field implementations to enhance the pavement base/sub base properties. The cylinders are derived from waste automobile tires by stripping their side walls for use in pavement systems and several other applications. The confined aggregates in geo-cylinders and geo-webs provide a stiffened base and help strengthening the pavement against applied vehicular loading. The objective of this research work is to evaluate the material and system behavior of the Mechanical Concrete ${ }^{\circledR}$ and other similar system to enhance the base/sub base properties of pavement. The typical geo-cells have up to 12 " wide openings with their heights vary from 6-8 inches. Thinwalled tire-derived geo-cylinders (TDGC) are approximately 24-26 inches in diameter with an approximate depth of 8-9 inches. The smaller tire derived cylinders (TDGC-S) are about 16-18 inches in diameter with a height of 6-8 inches. The geo-webs/cells and TDGCs are recommended to be filled with AASHTO \#57 aggregates. TDGCs have been implemented in multiple pavement settings exposed to large vehicular traffic, such as oil and gas drilling well-pads and road shoulder reinforcement in West Virginia and Texas (Bonasso, 2013). Geo-webs/cells have been implemented for pavement base and slope stabilizations. 


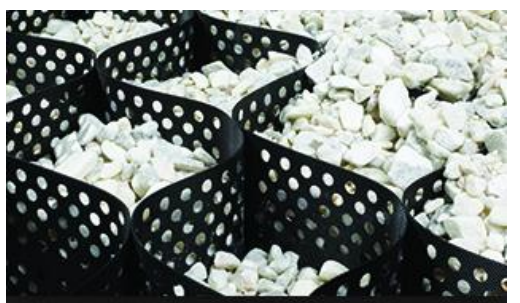

(a)

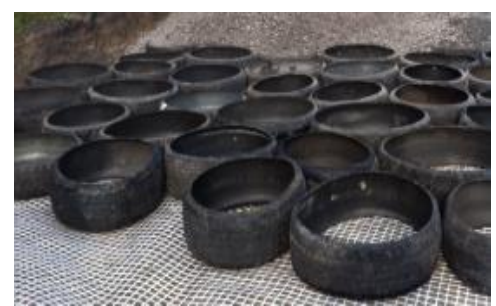

(b)

Figure 1. 1 Examples of pavement base/sub base materials (a) geo-web/cells (b) tire-derived geo-cylinders

\subsection{Objectives}

The primary objectives of this research are to:

(a) Conduct a literature review focusing on the pavement failures, chemical and cement stabilized subgrade, geosynthetic reinforcement mechanisms, and tire-derived geo-cylinder reinforcement including the use of static and dynamic laboratory tests.

(b) Determine mechanical and physical properties for the tire-derived geo-cylinders and geo-polymers

(c) Evaluate the behavior and performance of tire-derived geo-cylinders (TDGC) and geo-polymer reinforcement used for base/sub base property enhancement under static and fatigue loading.

(d) To observe the effects of post-fatigue loads on base/sub base moduli with the use of tirederived geo-cylinders and geo-cells.

(e) Evaluate the behaviors of the base/sub base moduli when loads are applied through HMA and PCC slab sections placed on top of the aggregate filled TDGC and geo-webs/cells.

(f) Discuss the effects of using pavement base/sub base strengthening schemes on the structural number and layer coefficients used in the design of flexible and rigid pavements as per the 1993 AASHTO guidelines and specifications.

(g) Review the potential cost estimates associated with TDGC installation for pavement systems.

(h) Evaluate the confinement effects of the TDGC and geo-webs/cells under static loads. 


\subsection{Organization of the Report}

This report is organized into six chapters. Chapter 1 presents the introduction and objectives of this study. Chapter 2 focuses on the literature review of some of the recent laboratory and field results pertaining to pavement failures and base/sub base reinforcement techniques. Chapter 3 describes an overview of the laboratory testing procedures for base/subbase strengthening schemes including mechanical concrete and geo-webs/cells. Chapter 4 presents the data obtained from laboratory experiments from static and fatigue load application for different base/sub base configurations on pavement representative sections constructed using wooden bins. Chapter 5 presents design methodologies based on the 1993 AASHTO Road Test and provides a cost analysis for TDGC reinforced base/sub base in flexible and rigid pavements. Chapter 6 presents the conclusions of this study and recommendations for field testing. The appendices address health related issues from silica and how TDGCs and geo-polymers have the ability to aid in the reduction of silica exposure, environmental concerns from tire waste/scrapping, and confinement testing. 


\section{LITERATURE REVIEW}

The literature review described in this chapter deals with the various issues related to applicable test methods for the evaluation of pavement performance with base/sub base strengthening methods. The review is provided for each of the discussed base/sub base enhancement technologies under separate sub-sections followed by conclusions.

\subsection{Base/Sub Base Enhancement Technologies}

\subsubsection{An Investigation of the Interlayer Adhesion Strength between the Granular Base and Lightly Cemented Sub base and Its Influence on the Pavement Performance (Ntirenganya et al. 2015)}

\section{Introduction:}

Ntirenganya et al. (2015) discussed the most effective materials to be incorporated in the subgrade to provide necessary traffic load distribution with minimum damages. They worked on roadway deterioration and failure modes in pavements such as ruts, cracks, potholes, etc. Tests were conducted on interlayer granular base and lightly cemented sub base to determine their ability in enhancing the pavement performance.

\section{Test Description:}

The tests were performed using two types of granular soils, a crushed hornfels stone as a base (G2) and cement treated subbase (CTSB) of G5 parent material in accordance with the South African material listings (SAPEM). Material properties such as Atterberg limits and Plasticity Index (PI) were obtained. Testing materials and methods used are shown in Figure 2.1.

Shear Trac-III load frame test set-up with a specimen of size $300 \mathrm{~mm}$ x $300 \mathrm{~mm}$ was used for conducting the tests (Figure 2.2). Vertical and horizontal values of displacement and shear were measured during this testing. Direct shear tests were conducted between the base and subbase to understand the internal shear response. Saturated and unsaturated conditions were also analyzed under direct shear tests. To ensure uniform compaction, a vibratory compactor was used on the lab tested specimen. A wet blanket covered the CTSB sub base for 7 days to allow for curing. 


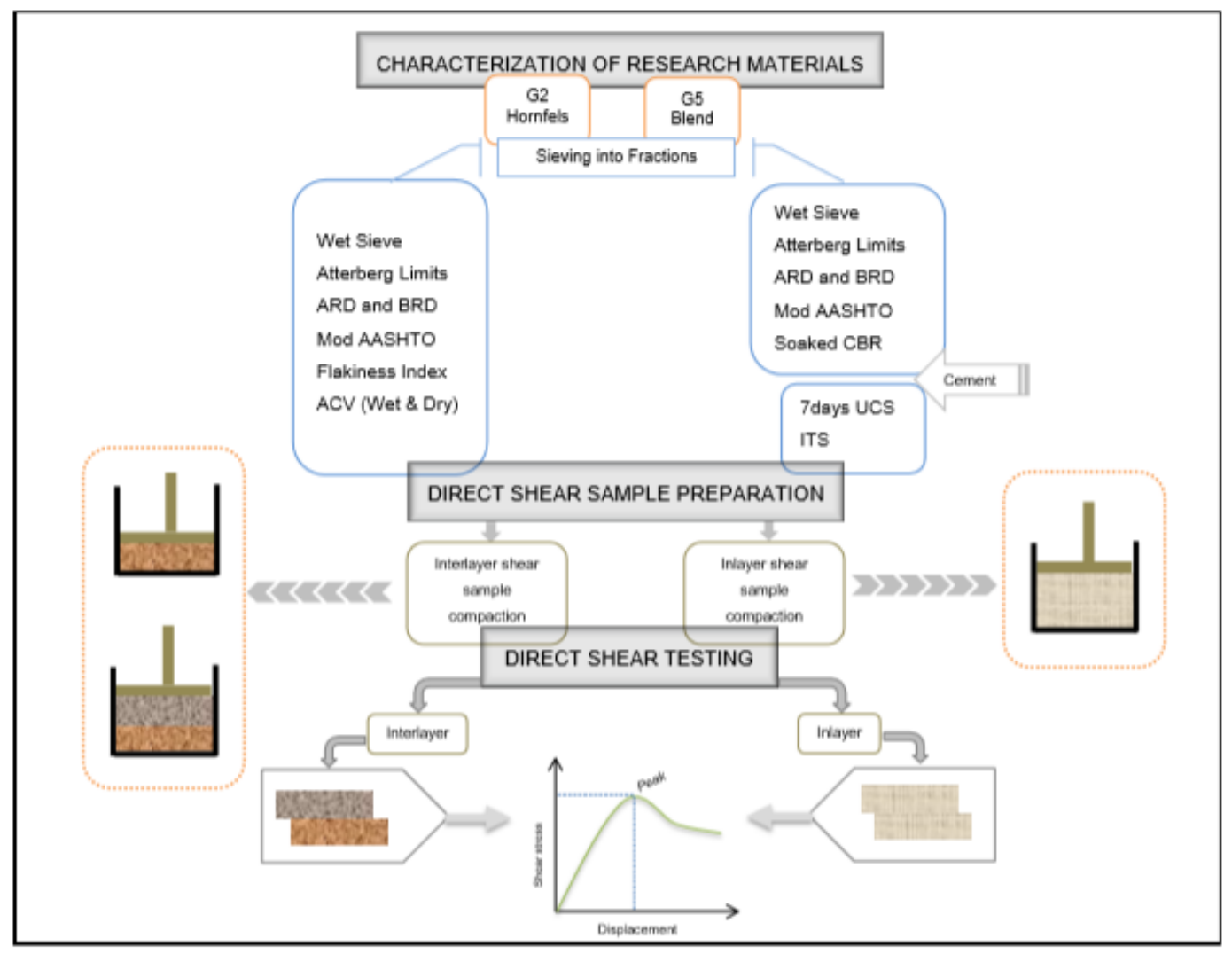

Figure 2. 1. Characterization of research materials (Ntirenganya et al. 2015)

\section{$\underline{\text { Results: }}$}

The tests focus on the response of the soil interface to shear forces. The charts show the results based on the use of CTSB, granular material and the resistance against horizontal movement. (Figure $2.3 \& 2.4$ ).

This research showed a trend of increase in stress and strain when interlayer friction between granular base (GB) and cement treated subbase (CTSB) changes from full friction to complete slip. The granular base (GB) demonstrated poor behavior and was highly sensitive to adhesion. Poor adhesions between the GB and CTSB on the pavement was noticeable in testing, and the pavement life had a substantial decrease when partial friction was allowed. The GB showed earlier failure than other layers in the system. 


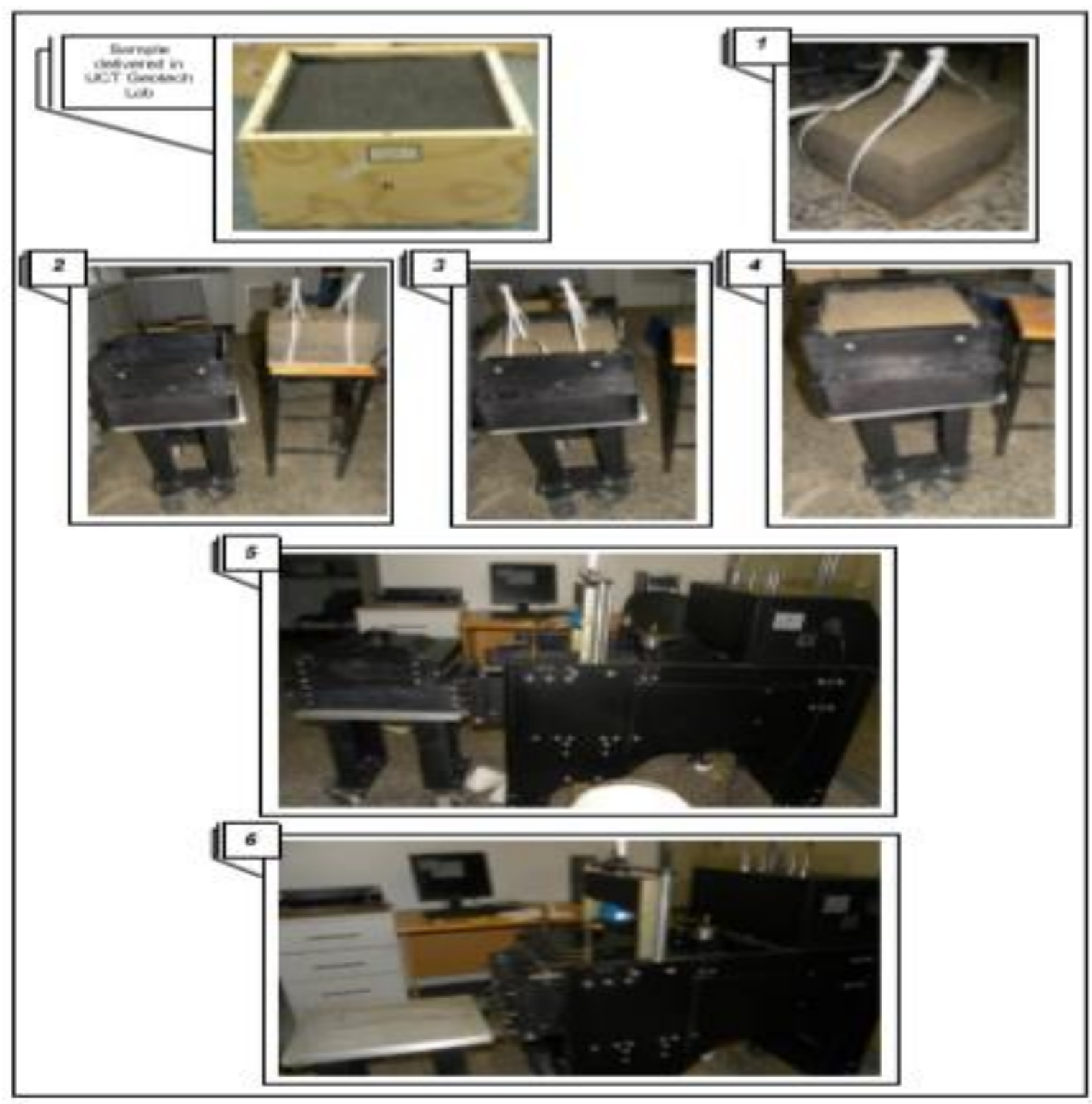

Figure 2. 2 Photographic illustration of specimen set up in the Shear Trac-III load frame 


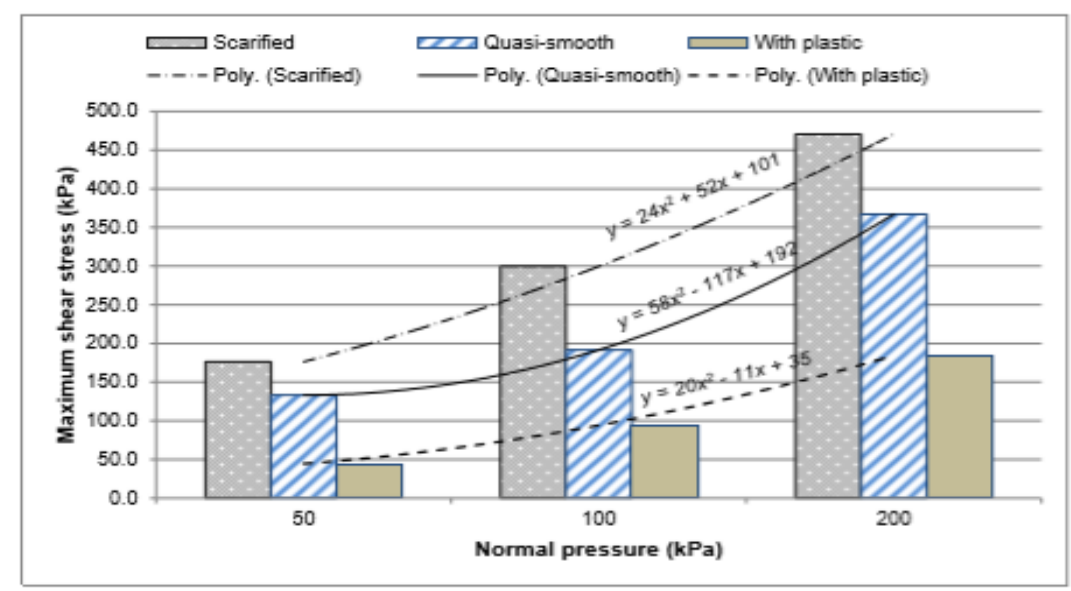

Figure 2. 3 The effect of the normal pressure and CTSB surface condition on the interlayer shear stress (Ntirenganya et al. 2015)

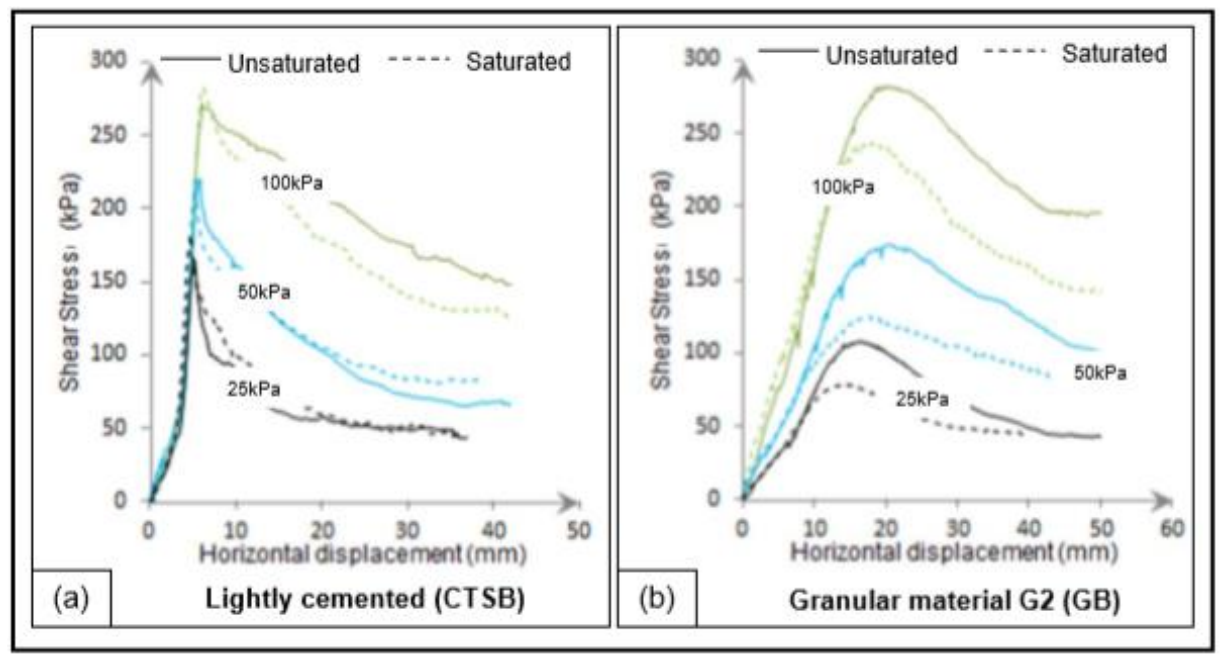

Figure 2. 4 Shear stress versus horizontal displacement for inlayer tests with $19 \mathrm{~mm}$ maximum aggregate size(Ntirenganya et al. 2015)

\section{Conclusions:}

In conclusion, traffic loads induce stress and strain on the pavement layers. Life of the pavement layers diminished when there was a lack of interlayer adhesion. Poor adhesion of the GB and CTSB with interlayer friction was observed to reduce axle loadings on the layers before reaching failure criterion. Interlayer shear conditions can influence pavement performance, and the interlayer adhesion can be increased with an increase of confinement. 


\subsubsection{Behavior of Composite Pavement foundation Materials Subjected to Cyclic Loading (Wolfe et al. 2011)}

\section{Introduction:}

Wolfe et al. (2011) examined the stiffness properties, moisture content (MC), and density characteristics of pavement foundation materials (Table 2.1). Resilient moduli from empirical calculations were compared with the values obtained from laboratory experiments. Analysis of resilient moduli behavior was conducted in pavement foundations through sampling. This research provided groundwork towards improving methodology for pavement foundation design and quality control/ quality assurance (QC/QA).

\section{Test Description:}

Tests were carried out in the lab and field to compare resilient moduli of pavement foundations. Index properties, gradation, and other in-situ procedures were conducted. Specimens were tested at six sites spanning four states in the US. Atterberg limit tests, proctor tests, relative density tests, etc. were conducted on specimens at each location. Table 2.1 shows a summary of lab soil tests conducted according to ASTM standards.

Cement and fly ash samples were collected from soils from Pennsylvania (PA US-22) and Iowa (IA I-29). Specimens were cured and settled in accordance with ASTM standards prior to testing.

Mechanical properties of tested materials were determined at each location. The field tests such as falling weight deflectometer (FWD), plate load test (PLT), nuclear moisture-density gauge (NG), and dynamic cone penetrometer (DCP) were used (Table 2.2). Materials tested includes base and sub base specimens, cement-treated base (CTB), asphalt-treated base, and high-density polyurethane (HDP) foam injection stabilizer. 
Table 2. 1 Summary of methods used for laboratory soil tests (Wolfe et al. 2011)

\begin{tabular}{|c|c|}
\hline Laboratory Test & Test Method \\
\hline $\begin{array}{c}\text { Standard Test Method for Particle-Size } \\
\text { Analysis of Soils }\end{array}$ & ASTM D422-63 \\
\hline $\begin{array}{c}\text { Standard test Method for Liquid Limit, Plastic } \\
\text { Limit, and Plastic Index of Soils }\end{array}$ & ASTM D4318-10 \\
\hline $\begin{array}{c}\text { Standard Test Method for Density, Relative } \\
\text { Density (Specific Gravity), and Absorption of } \\
\text { Coarse Aggregate }\end{array}$ & ASTM C127-07 \\
\hline $\begin{array}{c}\text { Standard Test Method for Specific Gravity of } \\
\text { Soil Solids by Water Pycnometer }\end{array}$ & ASTM D854-10 \\
\hline $\begin{array}{c}\text { Standard Test Method for Laboratory } \\
\text { Compaction Characteristics of Soil Using } \\
\text { Standard Effort (12,400 ft-lbf/ft }{ }^{3} \text { (600 kN- } \\
\text { m/ }{ }^{3} \text { ) }\end{array}$ & ASTM D698-07 \\
\hline $\begin{array}{c}\text { Standard Test Method for Laboratory } \\
\text { Compaction Characteristics of Soil Using } \\
\text { Modified Effort (56,000 ft-lbf/ft }{ }^{3} \text { (2,700 kN- } \\
\text { m/m }{ }^{3} \text { ) }\end{array}$ & ASTM D1557-09 \\
\hline $\begin{array}{c}\text { Standard Test Methods for Maximum Index } \\
\text { Density and Unit Weight of Soils Using a } \\
\text { Vibratory Table }\end{array}$ & ASTM D4253-00 \\
\hline $\begin{array}{c}\text { Standard Test Methods for Minimum Index } \\
\text { Density and Unit Weight of Soils and } \\
\text { Calculation of Relative Density }\end{array}$ & ASTM D4254-00 \\
\hline $\begin{array}{c}\text { Standard Method for Test for Determining the } \\
\text { Resilient Modulus of Soils and Aggregate } \\
\text { Materials }\end{array}$ & \\
\hline
\end{tabular}

Table 2. 2 Summary of devices and methods used for in situ soil testing (Wolfe et al. 2011)

\begin{tabular}{|c|c|}
\hline Test Device & Method Followed \\
\hline Falling Weight Deflectometer (FWD) & FHWA 2000 \\
\hline Plate Load Test (PLT) & ASTM D1196 \\
\hline Nuclear Moisture-Density Gauge (NG) & ASTM D6938-10 \\
\hline Dynamic Cone Penetrometer (DCP) & ASTM D6951/D6951M-09 \\
\hline
\end{tabular}




\section{$\underline{\text { Results: }}$}

Three materials were stabilized using different chemical techniques. In the Iowa specimen, fly ash was mixed into the subgrade, and high-density polyurethane (HDP) foam was injected into the Pennsylvania US-22 specimen. A $40 \%$ increase in resilient moduli was obtained in the Iowa specimen by the addition of fly-ash when layered with recycled concrete base (RPCC) base. A $25 \%$ decrease in resilient moduli was observed in the Pennsylvania specimen when injected with the HDP foam stabilizer. Fly-ash and cement treated subgrades were kept at constant densities for single and composite material samples. Resilient moduli were more likely to change due to upper layer property enhancement in the sub base structure. The resilient moduli are dependent on composite stiffness in the layered system. Increase of stiffness in the weakest layer will increase the overall stiffness of the composite system. Figure 2.5 shows the summary of resilient moduli in each independent testing scenario.

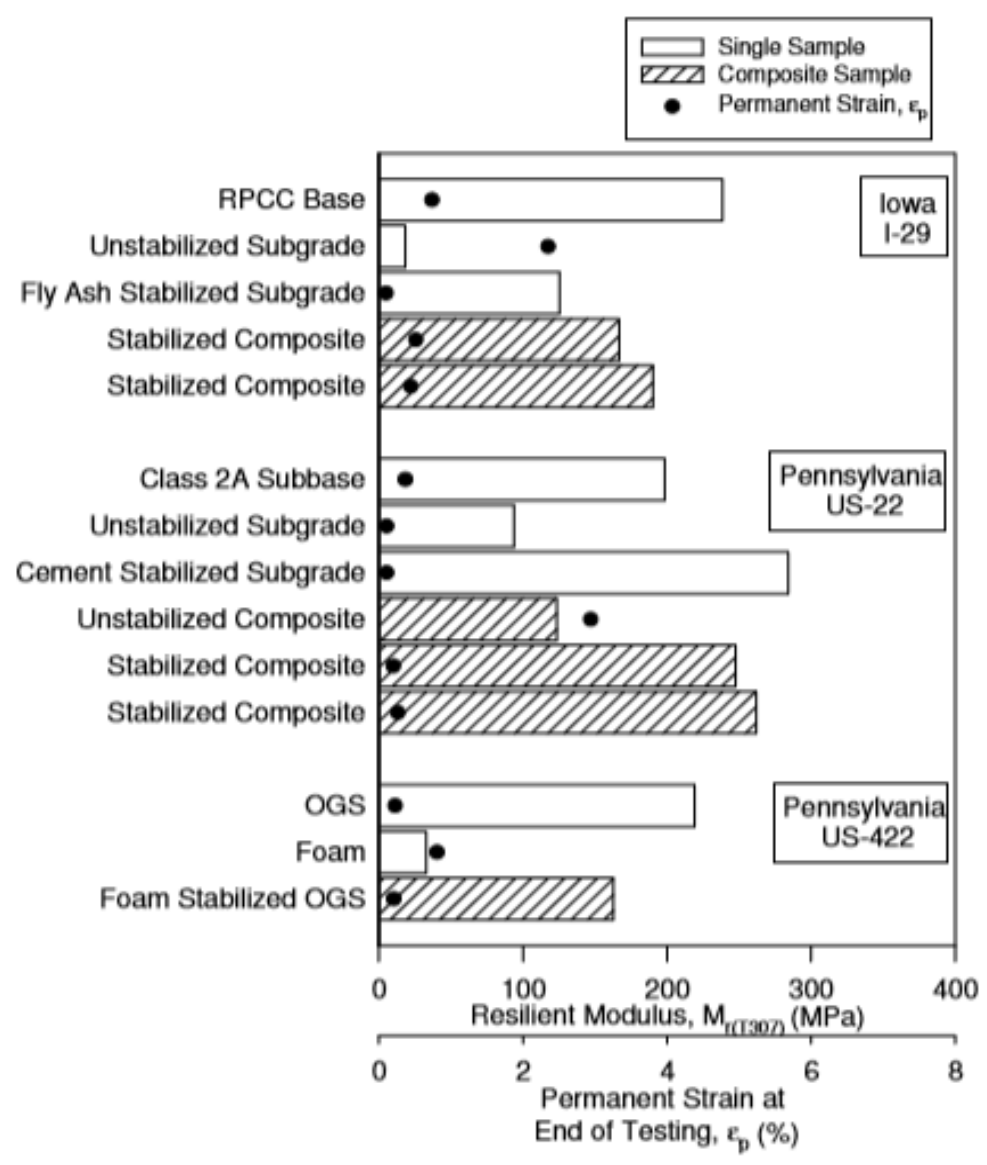

Figure 2. 5 Summary of resilient moduli for stabilized materials (Wolfe et al. 2011) 


\section{Conclusions:}

Increased saturation and moisture content resulted in a reduction in the resilient moduli of each specimen. It was observed that there was no increase in the resilient moduli with the addition of geo-fabrics at the interface of soils layers. The soil's characteristics, amount of stabilizer, and stabilizer type were found to affect the resilient moduli. Inconsistencies were observed between laboratory and in-situ data related to resilient moduli.

Highway pavement design parameters can be distinguished from values collected by state departments of transportation, and they can be compared to laboratory measured moduli. Resilient moduli were regional and indicative of site characteristics. Lab resilient moduli were greater than the design values and lab elastic moduli were less than design values. Boundary condition and edge effects were found to influence the results obtained. These investigations suggest that there was non-uniformity in the pavement foundation conditions.

\subsubsection{Mechanical Properties of Soil-RAP-Geopolymer for the Stabilization of Road Base/Sub Base (Adhikari et al. 2017)}

\section{Introduction:}

Pavements are subjected to dynamic loadings, and therefore, it is important to know soil specimen characteristics. Soil characteristics such as strength, stiffness, and durability play an important role in the life of a pavement system. Soil-cement and soil-RAP (recycled asphalt pavement) - geo-polymer were examined by Adhikari et al. (2017) in the state of Louisiana as additives to improve the pavement performance. Enhancement was observed in the mechanical properties such as strength, stiffness, and shrinkage. Geo-polymer mixtures and soil-cement combinations were compared by statistical based regression models.

\section{Test Description:}

Two specimens were collected and tested from different locations in Louisiana. Soil 1 was a medium plastic soil, and Soil 2 was a high plastic soil. American Standard of Testing of Materials (ASTM) and American Association of State Highway and Transportation Officials (AASHTO) standards were followed for testing soil specimens. Properties of both specimens were calculated from Atterberg limit tests, dry densities, grain size distributions, etc. Various tests were conducted on strengthening of the soil specimen and agent stabilizing combinations. 


\section{$\underline{\text { Results: }}$}

Data was obtained regression models were developed to estimate unconfined strength of the reinforced soil specimens. Stress-strain relations were established for soil 1 and soil 2 as shown in Figure 2.6. Figure 2.6 shows elastic properties of soil-cement and soil-RAP mixtures per soil specimen in the form of cement percent (\%) added to each soil specimen.

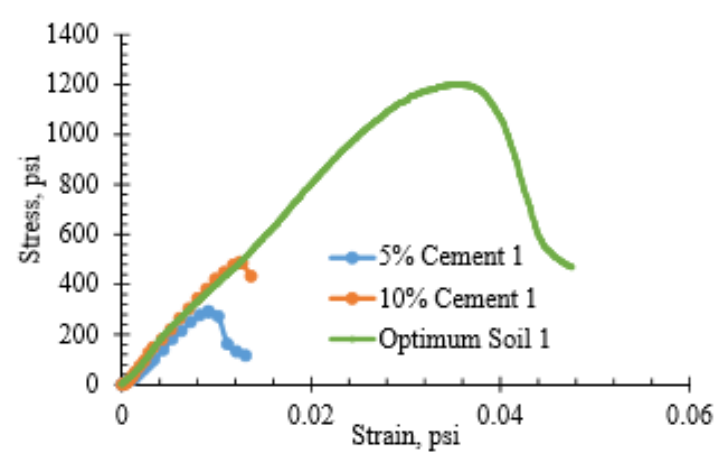

(a)

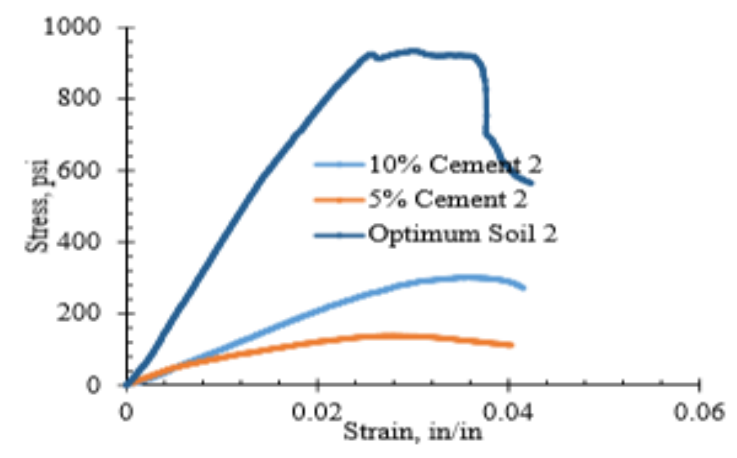

(b)

Figure 2. 6 (a) Soil 1 typical stress-strain diagram (b) Soil 2 typical stress-strain diagram (Adhikari et al. 2017)

\section{Conclusions:}

The study concluded that geo-polymers could be effective as reinforcement mechanism, and stiffness values increased based on the cement content of soil-cement mixtures.

\subsubsection{Evaluation of Structural Properties of Lime Stabilized Soils and Aggregates (Little, 1999)}

\section{Introduction:}

Lime can modify and stabilize subgrades. With the addition of lime to soil, minor modifications tend to occur in fine grained soils while substantial modifications occur in clayey soils of moderate to high plasticity. Stabilization was observed when the lime is added to a reactive soil type. Stabilization means that the soil gains long-term strength through the pozzolanic reaction process, which is formation of calcium silicate hydrates and calcium aluminate hydrates, when the lime reacts with aluminates and silicates solubilized from clay minerals. Stabilization can cause a significant increase in resilient modulus and shear strength. The modification process is used as an expedient approach for construction application and improvements in the California Bearing Ratio 
(CBR). Little (1999) examined the design protocol of AASHTO by enhancing pavement system properties with lime. Lime has been used to effectively enhance the subgrade properties which include the resilient modulus, fatigue properties, moisture resistance, etc. When lime, by itself, cannot reach desired properties in the subgrade soil, it can be combined with fly ash. The mixture will allow the soil subgrade to obtain proper strength improvements and resilient properties. Properties such as strength over time, resilient properties, deformation or the potential of deformation, fatigue response to traffic loads, moisture susceptibility, and laboratory and field relationships are described as items of interest in this research.

\section{Design Approaches:}

The AASHTO Guide for the Design of Pavement Structures is the main design approach used in the United States pertaining to the design of pavements. The code was established in 1961, and it provides an in-depth guide to pavement protocol. Portland Cement Concrete (PCC) was added to the AASHTO standards in 1981. The code discusses design approach along with the proper means to reinforce the pavement subgrade. The flexible pavement research of the AASHTO Road Test was conducted from 1958 to 1960 in Ottawa, Illinois, and it was a full experiment procedure to assess pavement layer thicknesses when subject to high level loads. The test was limited by the bounds of the site and climatic conditions. The test considered seven loops (including single and tandem axle loads). The performance equation (Equation 2-1) is critical for selecting the proper design based on the layer thicknesses and coefficients. 
Equation 2.1 (1993 AASHTO Road Test)

$$
\begin{gathered}
\log _{10} \mathrm{~W}_{18}=\mathrm{Z}_{\mathrm{R}} * \mathrm{~S}_{\mathrm{o}}+9.36 * \log _{10}(\mathrm{SN}+1) \\
-0.20+\log _{10}\left\{[\Delta \mathrm{PSI} /(4.2-1.5)] /\left[0.40+1094 /(\mathrm{SN}+1)^{5.19}\right]\right\} \\
+2.32 * \log _{10} \mathrm{M}_{\mathrm{R}}-8.07
\end{gathered}
$$

Where:

$$
\begin{aligned}
& \mathrm{W}_{18}=\text { number of } 80 \mathrm{kN} \text { single load axles } \\
& \mathrm{Z}_{\mathrm{R}}=\text { standard normal deviate } \\
& \mathrm{S}_{\mathrm{o}}=\text { standard deviation of the data } \\
& \Delta \mathrm{PSI}=\text { loss of serviceability } \\
& \mathrm{M}_{\mathrm{R}}=\text { subgrade resilient modulus } \\
& \mathrm{SN}=\text { structural number of pavements in question }
\end{aligned}
$$

The major problem that designers' face while utilizing the above formulae is the selection of proper layer coefficients. To apply proper structural significance to the pavement structure, mechanistic-empirical design is suggested to be considered to develop proper material assignment to the pavement. This paper further discusses layered elastic modeling (LEM) along with finite element modeling (FEM). These methodologies discuss the importance of obtaining the resilient modulus of the system and displaying data in accordance with distress and climatic modeling.

\section{$\underline{\text { Results: }}$}

Both laboratory and field data were collected by the Texas Department of Transportation (TxDOT) to further the understanding of lime use to stabilize in-situ soil subgrade properties. Experts generally focus on strength, resiliency, fracture/ fatigue, and durability properties when examining sub base/base enhancement. The information obtained concerning lime's influence on soil properties and strength were accrued from literature. Tests such as the direct-shear test, unconfined compressive strength test, CBR test, etc. were conducted. Reviewing the results from literature, sub base and base layers that are stabilized by a means of Portland Cement Concrete (PCC), lime, fly ash, or lime-fly ash see a substantial change in the distribution of stresses within the pavement system. Repetition of high induced loading can be detrimental to the system and can 
lead to crack initiation and propagation. Pavement layer thicknesses may need to be adjusted accordingly in order to keep stresses within tolerable levels.

\section{Conclusions:}

Little (1999) concluded that soil and aggregate must be sufficiently altered to achieve proper resilient, strength, and deformation properties. This study recommends the use of an extended mixture design protocol for lime stabilized bases and subbases. Following this design report, it is necessary to obtain realistic properties of the stabilized layers from laboratory and field.

\subsubsection{Proposed Geoscientific Method for Determining Optimum Geosynthetics Embedment Location for Enhanced Performance of Geo-Structures (Mukabi, 2013)}

\section{Introduction:}

Geosynthetic use has increased in recent years as they can be used for wide range of applications. Without quantitative data, designers can have a difficult time placing these materials in the proper soil settings for optimization. Failures of composite geo-structures tend to occur due lack of knowledge in installation practices. For example, some experts believe that geogrids, a type of geosynthetic, should be placed near the load, while others proclaim it should be placed below or at the mid-height. Mukabi (2013) discussed the stresses and strains obtained from geogrid placement according to the Mohr-Coulomb criteria. This study discusses normal stresses pertaining to geosynthetic reinforced soils and deflection due to adopted geo-materials.

\section{Test Description:}

The geo-materials adopted for testing were standardized through the Optimum Batching Ratio Method (OBRM) to ensure that uniformity, consistency, and exhibition of similar intrinsic data is incurred. Grading characteristics were calculated from the Optimum Mechanical and Chemical (OPMC) methodology and sieve analysis. Other conditions examined in this research were geosynthetic embedment, type and cross section analysis of geosynthetics, installation damage, degree of saturation, loading intensities, etc.

\section{$\underline{\text { Results: }}$}

Results displayed the effectiveness of placing the geogrid at optimum heights as per the soil type studied. Effect of variation of geosynthetics embedment location with respect to geogrid 
and geomat for non-stabilized soil and OPMC stabilized gravel for tested soil specimens are shown in Figure 2.7.

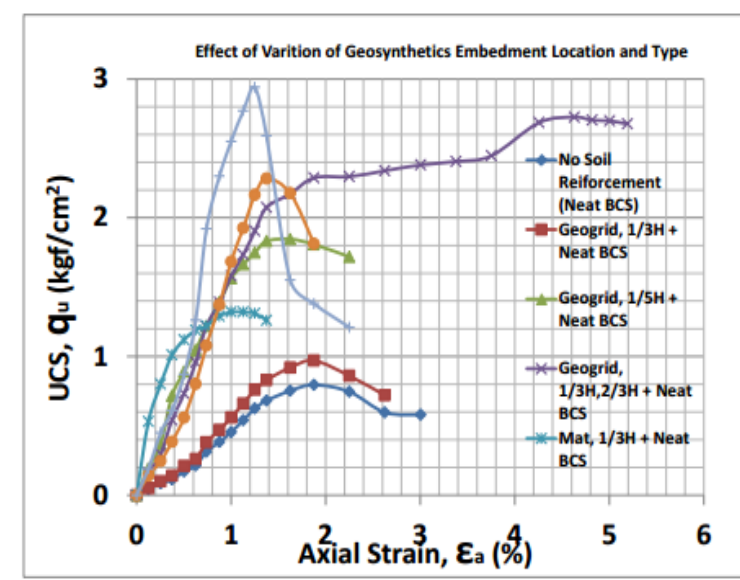

(a)

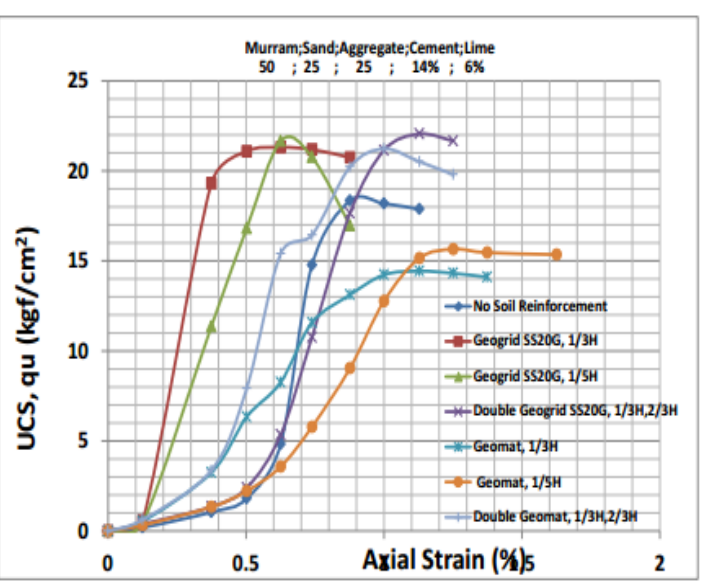

(b)

Figure 2. 7 Effect of variation of location of geosynthetics embedment and type for; a) non-stabilized sandy black cotton soil (BCS)

b) OPMC (Optimum Mechanical and Chemical) stabilized gravel (Mukabi 2013)

Field testing was conducted using the dynamic cone penetration apparatus for design purposes, pad foundations, and construction on oil pads in South Sudan. One test was carried out to further examine the progressive increase away from the location of geogrid embedment. Geogrid embedment placement can be postulated except for the effect of surcharge, compaction, and consolidation principles which influenced stresses and their rate of progressive increase. The data confirmed presence of a transition zone, which agrees with data obtained in laboratory experiments. Mukabi (2013) concludes that it is a matter of the geotechnical engineer and economic importance to delineate the establishment of certain "particular performance-based specifications" for geosynthetic reinforcement.

\section{Conclusions:}

This data concludes that geosynthetics can influence bearing capacities, enhance strength, deformation resistance, and can help alleviate deflection. Multi-layer geosynthetics may be proposed for usages depending on the site soil conditions. Research shows that geogrids almost has no benefit in fine-grained soils. Knowledge of the site and soil characteristics is imperative to proper geosynthetic selection. 


\subsubsection{A Study of Pavement Deformation Behavior of Geogrid-Reinforced Flexible Pavements Using Small Scale Accelerated Pavement Testing (Tang et al. 2011) \\ Introduction:}

Weak subgrades are a major concern in pavement systems. Steps to minimize subgrade influence on pavement include increasing the pavement layers, removal of the top soil layer and backfilling it with a soil of higher bearing capacity and properties to resist frost/heave, addition of lime, fly ash, other stabilizing chemicals, and geosynthetics to aid soil stabilization. Geogrids, a type of geosynthetics, have been used in flexible pavement systems. Geogrids reinforce the pavement and resist deformation from loadings. Tang et al. attempts to develop design guidelines or methods for flexible pavement systems with geogrid reinforcement. They used mechanisticempirical methodology to incorporate obtained data and attempted to develop permanent deformation models.

\section{Research Approach:}

Geogrid properties in pavement systems were examined from multi-scaled tests and benchscale tests to determine physical and mechanical properties of geogrids and pavement materials. Finite Element Models (FEM) were used for simulation of pavement responses for the accelerated pavement testing (APT) conditions. In conjunction with the inverse analysis, lightweightdeflectometer tests were also conducted to obtain pavement properties. Permanent deformation models were developed for unreinforced pavements to assess pavement load responses. These models helped understand the results with the addition of geogrids in a pavement system. Tests were conducted using ASTM testing standards for pavement and geogrids. APT tests were conducted in four sets, Exploratory APT I, II and Instrumented APT III, IV, having four sections each. Soil properties were determined in Exploratory APT I and APT II by CBR tests, index tests, grain size distribution, nuclear gauge, etc. following soil placement and compaction using a vibratory plate compactor. Properties of the geogrids were found from various testing procedures including the pull-out test. Instrumented APT III and APT IV were used to determine the performance of permanent deflection of pavements.

\section{Results:}

Results were examined and discussed on the use of geogrids in pavement systems from all testing methods. Discussion centered on how dynamic loading generated from the wheel loadings 
can lead to increased pore pressure in some cases. When pore pressure exceeded total soil stresses, soil slurry might be generated, which is said to contribute to the migration of fines within the aggregate base. This observation is shown in Figure 2.8.

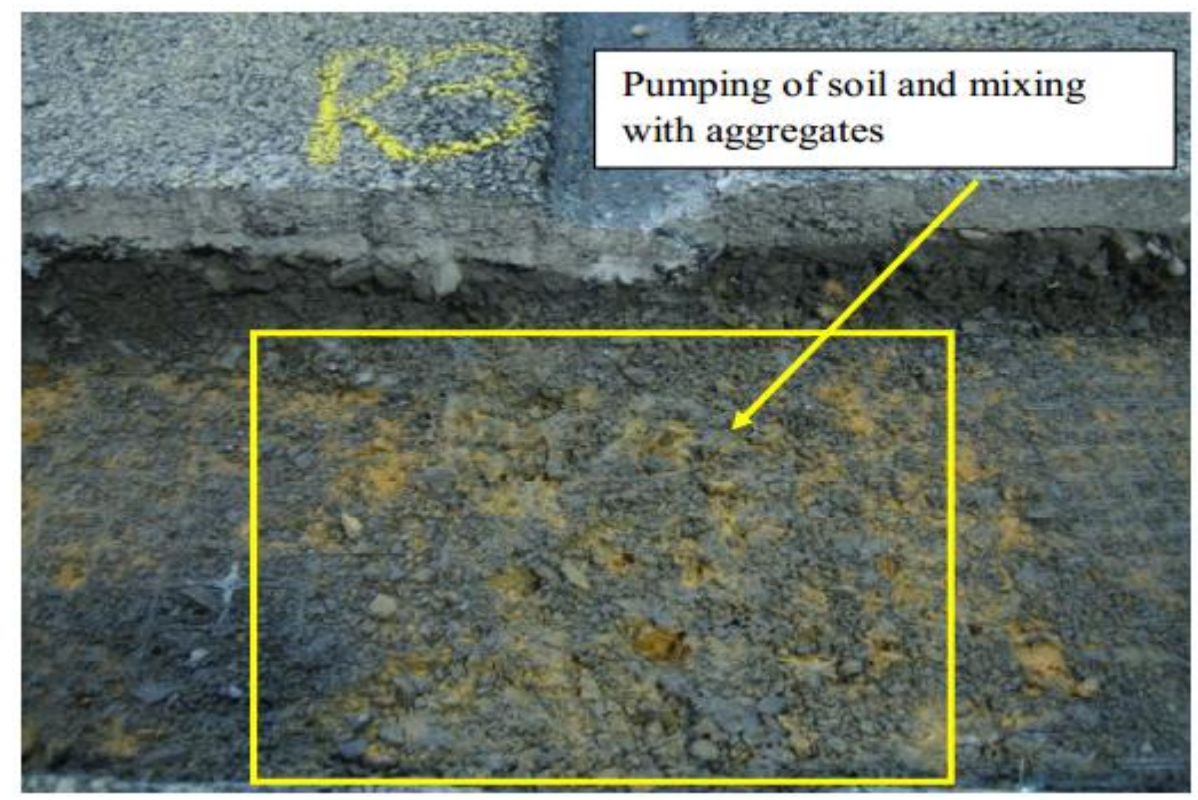

Figure 2. 8 Soil slurry pumped up above the geogrid and migrated into the aggregates (Tang et al. 2011)

Benefits of exploratory APT II tests conducted on SM-silty sand soil after geogrid installations as compared to APT 1 with more surface rutting and deformation as seen in Figure 2.8. Inspection of trenches shows that geogrids cannot prevent fines from entering the base. They can act as a separator for coarser aggregates. Instrumented APT tests found altered boundary effects and dimensions. Finite element analysis models simulated the site with the use of AASHTO \# 57 aggregate through inverse analysis of previous tests. The input values are shown in Table 2.3. 
Table 2.3 Inputs for FE model (Tang et al. 2011)

\begin{tabular}{|c|c|c|c|c|}
\hline Layer & $\begin{array}{c}\text { Thickness } \\
\text { (cm/in) }\end{array}$ & $\begin{array}{l}\text { Modulus } \\
\text { (MPa/psi) }\end{array}$ & Poison's Ratio & Load \\
\hline $\begin{array}{c}\text { Asphalt } \\
\text { Concrete (AC) }\end{array}$ & $4 / 1.5$ & $2,758 / 400,000$ & 0.2 & \multirow{4}{*}{$\begin{array}{l}\text { Pressure: } 689 \\
\text { kPa (100 psi) } \\
\text { Contact radius: } \\
3.5 \mathrm{~cm}(1.39 \text { in) }\end{array}$} \\
\hline Base Coarse & $10 / 4$ & $290 / 42,061$ & 0.3 & \\
\hline Subgrade & $113 / 44.5$ & $30 / 4,351$ & 0.4 & \\
\hline AASHTO \# 57 & $127 / 50$ & $150 / 21,756$ & 0.3 & \\
\hline
\end{tabular}

Lightweight Deflectometer (LWD) Testing, MMSL3 Testing, Instrumentation Processing were performed by Tang et al. Parameters of the tested soil samples were altered based on the temperature of concrete, moisture content of the soil specimens, elastic and permanent deformation properties, vertical stress alteration, and strain developed within the geogrids. Table 2.4 shows the relationship of index and bench-scale properties according to accelerated testing of the samples.

Table 2. 4 Relationship between selected index and bench-scale properties with subgrade permanent deformation from accelerated testing (D: Direct, I: Indirect, N: No observed trend)

(Tang et al 2011.)

\begin{tabular}{|c|c|c|c|}
\hline \multirow{2}{*}{ Property } & \multicolumn{3}{|c|}{ Correlation and Observed Trend } \\
\cline { 2 - 4 } & Shear Modulus & Efficiency Factor & $\begin{array}{c}\text { Subgrade } \\
\text { Permanent } \\
\text { Deformation }\end{array}$ \\
\hline Tensile Modulus & $\mathrm{D}$ & $\mathrm{D}$ & $\mathrm{D}$ \\
\hline Junction Strength & $\mathrm{D}$ & $\mathrm{D}$ & $\mathrm{N}$ \\
\hline Junction Thickness & $\mathrm{D}$ & $\mathrm{D}$ & $\mathrm{N}$ \\
\hline Ultimate Strength & $\mathrm{I}$ & $\mathrm{I}$ & $\mathrm{N}$ \\
\hline Torsional Stiffness & $\mathrm{D}$ & $\mathrm{D}$ & $\mathrm{N}$ \\
\hline Flexural Rigidity & $\mathrm{D}$ & $\mathrm{D}$ & $\mathrm{D}$ \\
\hline Shear Modulus & & & $\mathrm{N}$ \\
\hline Efficiency Factor & & & \\
\hline
\end{tabular}

Modern instrumentation was used to obtain necessary data for the pavement system, and from the study, a correlation between the tested geogrid index properties, interface characterizations, and accelerated tests was formulated. Permanent deformation values indicate that the geogrid tensile modulus and interface shear modulus at small displacements play a vital role in pavement performance, and it is worth pointing out that this data correlates to a limited number of samples. 


\section{Conclusions:}

The properties of geogrids in pavement were individually obtained. Geogrids reduced deformations in a sub base as seen in APT II. Grids were not observed to benefit weak sub bases as rutting still occurred in these specimens as observed in APT I. In light of mechanistic-empirical design, prediction models were created for subgrade deformation from the limited experimental data collection. Although the model underestimated some parameters of soil deformations, it was able to rank the tested sections performance knowing factors such as subgrade properties, moisture content, stress state of subgrade, etc.

\subsubsection{Reinforcement of Pavements Over Expansive Clay Subgrades (Zornberg and Gupta, 2015)}

\section{Introduction:}

Zornberg et al. studied sub base reinforcement by the addition of geosynthetics to the pavement system. Two key benefits of geosynthetic use are improvements to pavement life and the ability to attain equivalent pavement performance while reducing the material used within the pavement systems. Geosynthetics can provide reinforcement through confinement properties, membrane support, and increase of the bearing capacity. The contribution of geosynthetics, such as geogrids in pavement, have led to controversial guidelines and post-construction evaluation criteria as the properties are still relatively unknown. New applications of basal reinforcement have been utilized in expansive clays at various locations in Texas to mitigate longitudinal cracking (Figure 2.9). The installation methodology used by the Texas Department of Transportation (TxDOT) can be observed in Figure 2.10 which shows the layout of geogrid reinforcement. The geosynthetic reinforcement is typically combined with lime or cement stabilization to further enhance expansive subgrade properties. This paper summarizes information learned by observing the performance evaluation from the traffic benefit ratio (TBR) and the base course reduction ratio (BCR). 


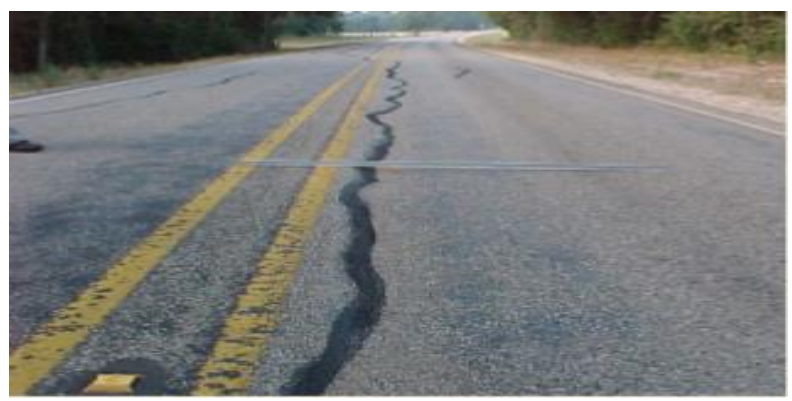

Figure 2.9 Typical longitudinal crack developed on pavements over expansive clays (Zornberg et al. 2015)

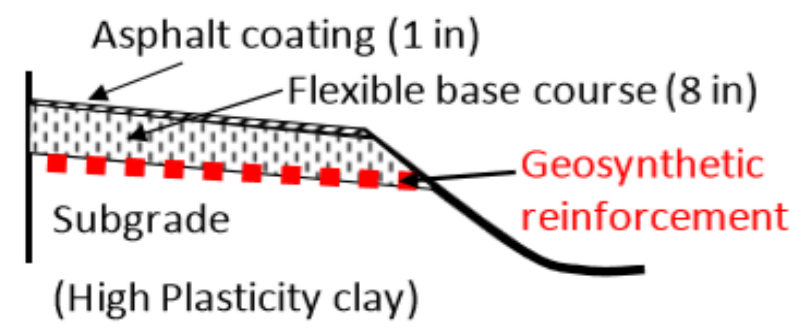

Figure 2.10 Typical pavement cross-section of a low-volume road in central Texas using reinforcement for mitigation of cracks induced by expansive subgrades (Zornberg et al. 2015)

\section{Mechanism of Longitudinal Cracking}

Construction of pavement roadways over expansive soils have often led to poor performance and deterioration of the pavement system. Environmental aspects are typically not covered in the design process, however the environment in which the system is placed in is an important parameter of pavement life. Shrink/swell conditions may occur during seasonal changes, and in accordance with cyclic loading of vehicular traffic, pavement can be susceptible to failure modes such as longitudinal cracking. The report from Zornberg and Gupta (2015) discusses that longitudinal cracking failures mostly occur due to seasonal and climatic changes in Texas.

\section{Field Evaluation}

Thirty-five sites were evaluated in the Dallas-Fort Worth area for expansive clay potential, and 30 of them reported to have high plasticity clays and pavement failure. Geogrid reinforcement was utilized for rehabilitation in 26 of these sites. Three distinct lessons are discussed in this report. In lesson 1, evaluation of geogrid effectiveness on base course thickness were observed in the case of Milam County, Texas. This section of the roadway incorporated the use of lime and geogrid to strengthen the in-situ soil conditions. Lesson 2 was based on the Leon County, Texas installation. 
The road surface along with the shoulder were rehabilitated with lime to stabilize the sub base and geogrids. However, this section prematurely failed as the appropriate length of geogrid was not being used by the contractor. Poor installation practices resulted in pavement failure even before the section of road could be opened to traffic. Even though failure was noticeable at the Leon County site, observations showed that geogrid reinforcement potentially relocated cracking within the pavement section. Lesson 3 relates to the lack of understanding by professionals regarding the properties of geogrids. A section of roadway in Grimes County, Texas was reconstructed with cement-lime stabilization for the sub base. The high plastic clay soil was also strengthened with 2 different types of geogrid. Geogrid A performed very-well and caused no significant damage to the pavement structure. Geogrid B failed and caused longitudinal cracking even though it met the design criteria (Figure 2.11). Failure of Geogrid B occurred at the junction point, or location where the longitudinal and transverse ribs meet.

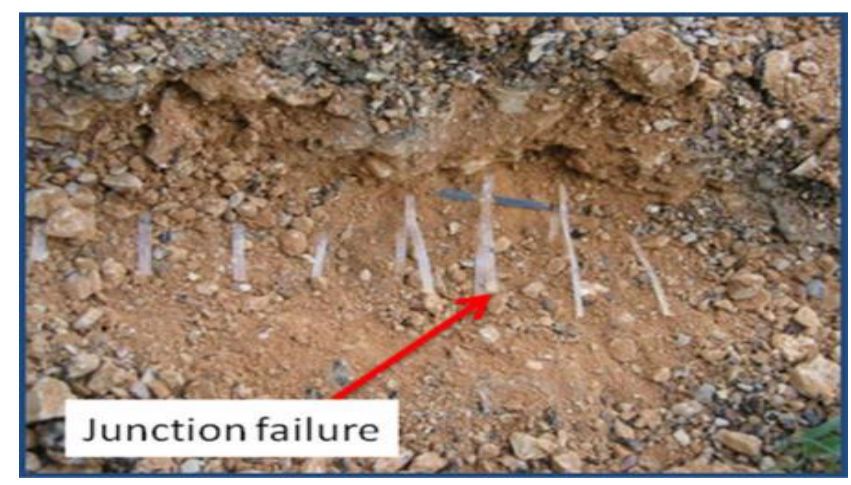

Figure 2. 11 Separation of longitudinal and transverse ribs at junctions of Geogrid B at location FM 1774 (Zornberg et al. 2015)

It was observed that failure of the geogrid was caused by tensile forces, even though design specifications were satisfied. Table 2.5 compares the geogrids according to their individual properties and characteristics from the TxDOT. 
Table 2. 5 Comparison of geogrid properties with specifications given by TxDOT (Zornberg et al. 2015)

\begin{tabular}{|c|c|c|c|}
\cline { 2 - 4 } \multicolumn{1}{c|}{} & Geogrid A & Geogrid B & Recommended \\
\hline Aperture, mm & 35 & 43 & $25-50$ \\
\hline Open Area (\%) & $75 \%$ & $74 \%$ & $70 \% \mathrm{~min}$ \\
\hline Tensile Modulus at 2 \% Strain (kN/m) & 215 & 385 & $200-300$ \\
\hline Ultimate tensile Strength, MD (kN/m) & 26 & 44 & - \\
\hline CMD (kN/m) & 21 & 55 & - \\
\hline Junction Strength (kN/m) & 22.5 & 11 & - \\
\hline Average Junction Efficiency (\%) & $93 \%$ & $35 \%$ & $70 \%$ min. \\
\hline
\end{tabular}

Conclusions:

Research conducted on pavements constructed over expansive clays concluded that geosynthetics can appropriately be added to the pavement structure to minimize the existence of longitudinal cracking. The location of longitudinal cracks has the potential to be altered as discussed from lesson 2. This is important to note because longitudinal cracks can possibly be moved beyond the reinforcement zone. Additional information is needed to further support the use of geogrids in expansive soils.

\subsubsection{Improvement of Pavement Foundation Response with Multi-Layers of Geocell Reinforcement: Cyclic Plate Load Test (Khalaj et al. 2014)}

\section{Introduction:}

Planar and cellular materials help to reinforce the base/sub base. Geocell reinforcement can have significant effects by utilizing the properties of cellular confinement. The cells allow for passive resistance which increases bearing capacity and reduces the settlement. Khalaj et al. (2014) studied the properties of geocells in relation to loading scenarios. This research covers geocell layers exposed to cyclic plate loading conditions to introduce the benefit of using the cells as a reinforcement mechanism. The main purpose is to determine the optimal depth of the first layer of geocells, the effects of multiple geocell layers have on the subgrade, and the effects of geocells on stress profiles within the foundation. 


\section{Test Description:}

Granular soil at the sub base was tested and analyzed according to ASTM standards and classified by the Unified Soil Classification System (USCS) as sand, SW. The geocell used to reinforce SW-sand consisted was comprised of polypropylene which was in a "honeycomb" pattern. The confinement cells, when filled create friction and passive resistance in the geocellsoil interface. The pocket size of the cell was $110 \mathrm{~mm}$ x $100 \mathrm{~mm}$. A test pit measuring $2000 \mathrm{~mm}$ x $2000 \mathrm{~mm}$ x $700 \mathrm{~mm}$ was manufactured for testing. Figure 2.12 displays the overall layout of the experiment and location of the soil pressure cells (SPC's) which recorded the vertical stress inside the foundation. A vibratory plate compactor was used when compacting the soil, and sufficient compaction was achieved in 10 soil lifts. A hydraulic jack was utilized to apply appropriate loading for analytical purposes. Loading patterns were selected to mimic the truck loadings that the surface is most likely to experience while in service. Six cyclic pressure loadings were applied while testing with different loading rates to exhibit real loading and unloading scenarios.

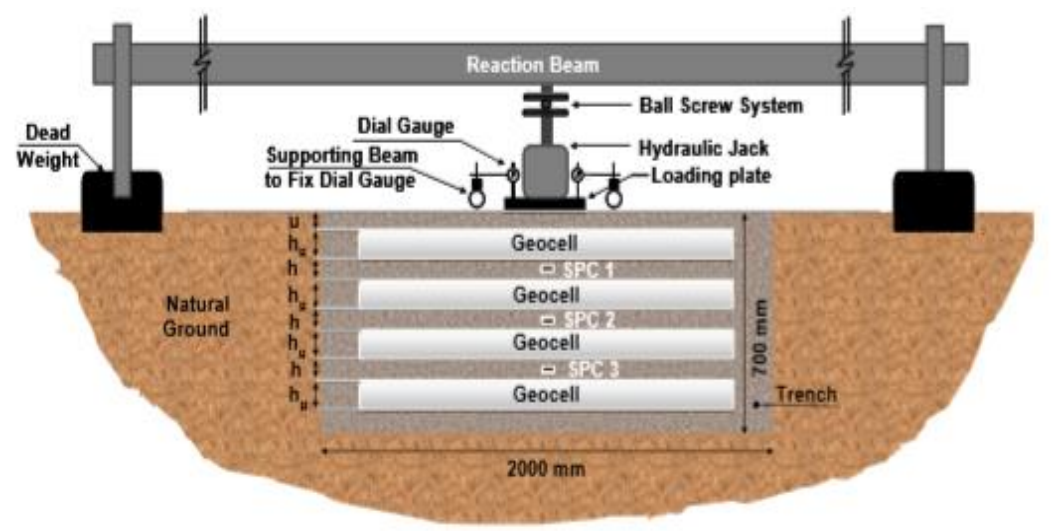

Figure 2.12 Schematic cross-section of the test set-up (not to scale), "SPC 1", "SPC 2", and "SPC 3" indicate the location of three soil pressure cells (Khalaj et al. 2014) 


\section{$\underline{\text { Results: }}$}
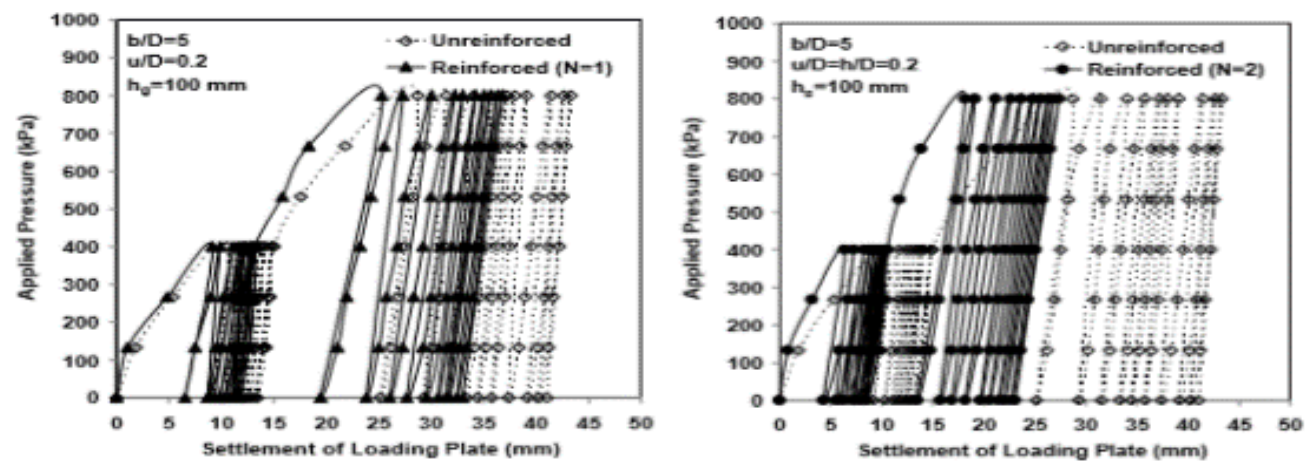

(a) $N=1$

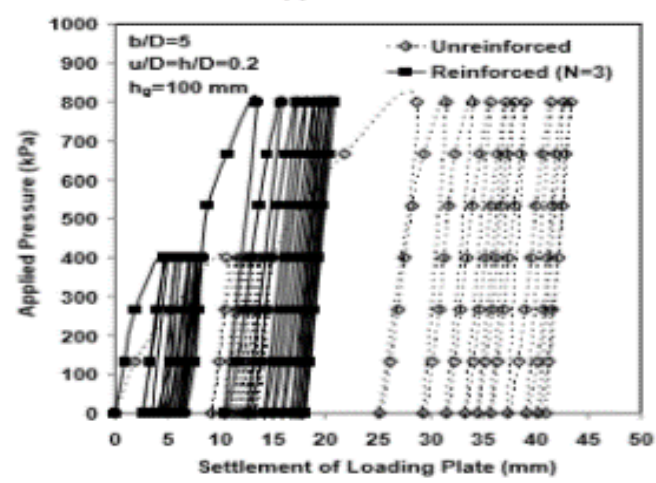

(c) $N=3$

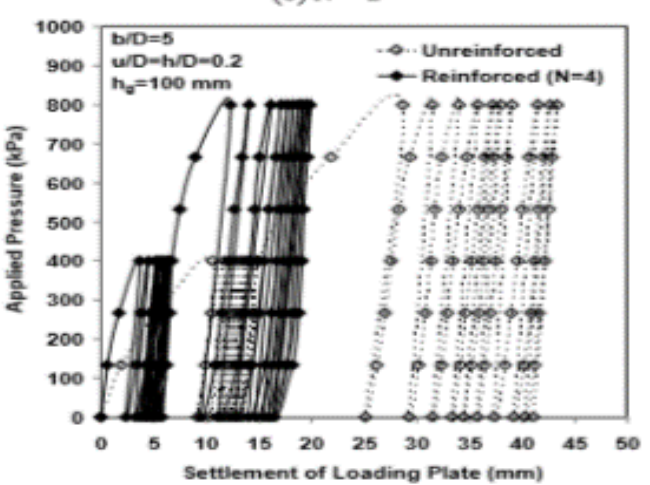

(d) $N=4$

Figure 2. 13 Comparison between unreinforced and improved geocell-reinforced installations for different layers of geocells (N) (Khalaj et al. 2014)

Figure 2.13 signifies that the total and residual settlements tend to increase with the number of loading cycles. Increase in geocell layers $(\mathrm{N})$ provided less peak settlement and less residual plastic settlement when compared to the unreinforced specimen. Reductions in displacement signify that the cells performed well in decreasing the settlement under cyclic loads.

Generally, stress reduction occurs with the use of geocells, as vertical stresses are transferred to the cell layers. The geocell layers can contribute to keeping the stress zone under the loading surface from displacing away by confining the material within the cells. This phenomenon prevents lateral movement of the material by increasing the shear strength of the system. The "confinement effect" allows the layer to act as a mat which disperses load over an extended area instead of directly corresponding to the point of contact. 


\section{Conclusions:}

From testing, the installment of these geocells can increase resilient behavior and total settlement of the pavement foundation due to load dispersion and energy absorbance of the geocells. Results can conclude that geocells protect pavement from rutting due to the accumulation of high residual plastic stresses.

\subsubsection{Three Dimensional Cellular Confinement System Contribution to Structural Pavement Reinforcement (Kief and Rajagopal, 2008)}

\section{Introduction:}

The use of geosynthetics can enhance the performance of flexible pavement systems that are on weak subgrade. This economic base/sub base reinforcement can provide increased load support to all-weather exposed roads. Geocells provide planar support, however they are a complex system. Three phases were studied include measuring: strength and stiffness of the geocell walls, ability of the geocell walls to withstand radial stresses while in service, and the composite reinforcement system to provide adequate bearing capacity and rutting resistance. Kief and Rajagopal (2008) examined geocells to understand their load responses, cost reductions, and maintenance.

\section{Test Description:}

The road rehabilitation process examined during this research consisted of removal of 12 meters of pavement from both sides of the road, removal of soil underneath the pavement system at a depth of $700 \mathrm{~mm}$, compaction of a new aggregate subgrade (compacted in lifts of 150 to 250 $\mathrm{mm}$ thick), observations at the untouched section of roadway where only cracks were filled, and application of a new asphalt layer of $175 \mathrm{~mm}$ thick to the entire road section. Instead of adding $700 \mathrm{~mm}$ of new aggregate sub base on one segment of the roadway, geocells were added as support. Geocells were installed by first compacting the subgrade, adding a new lift of compacted aggregate to a height of $150 \mathrm{~mm}$, and lastly, installing the geocells with sufficient aggregate fill (Figure 2.14). 


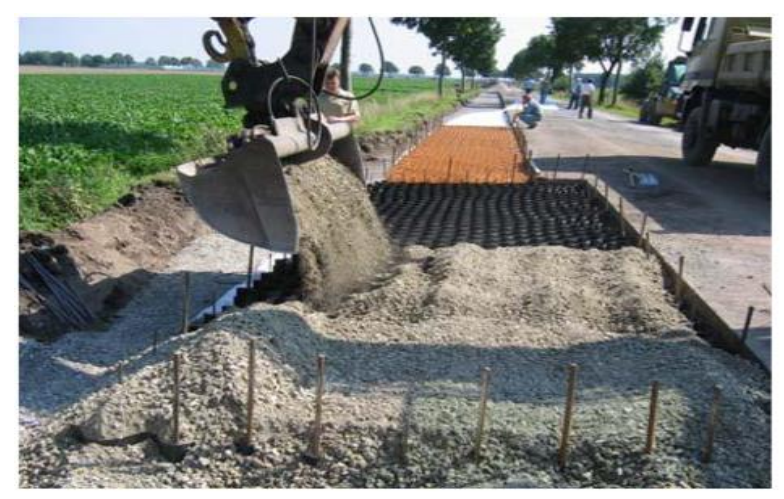

Figure 2. 14 Installation and infill of the geocell (Kief et al. 2008)

Static and dynamic tests were conducted on the road surface. Measurements were taken by earth pressure cells which were located directly under the geocell layer. Stresses were measured at three points in each of the rehabilitated pavement sections.

\section{$\underline{\text { Results: }}$}

The stresses measured are displayed in Figure 2.15, which shows the load distribution over the given area. The reinforced pavement system (geocell addition) is indicated by the bottom line, and the unreinforced pavement section is the top line.
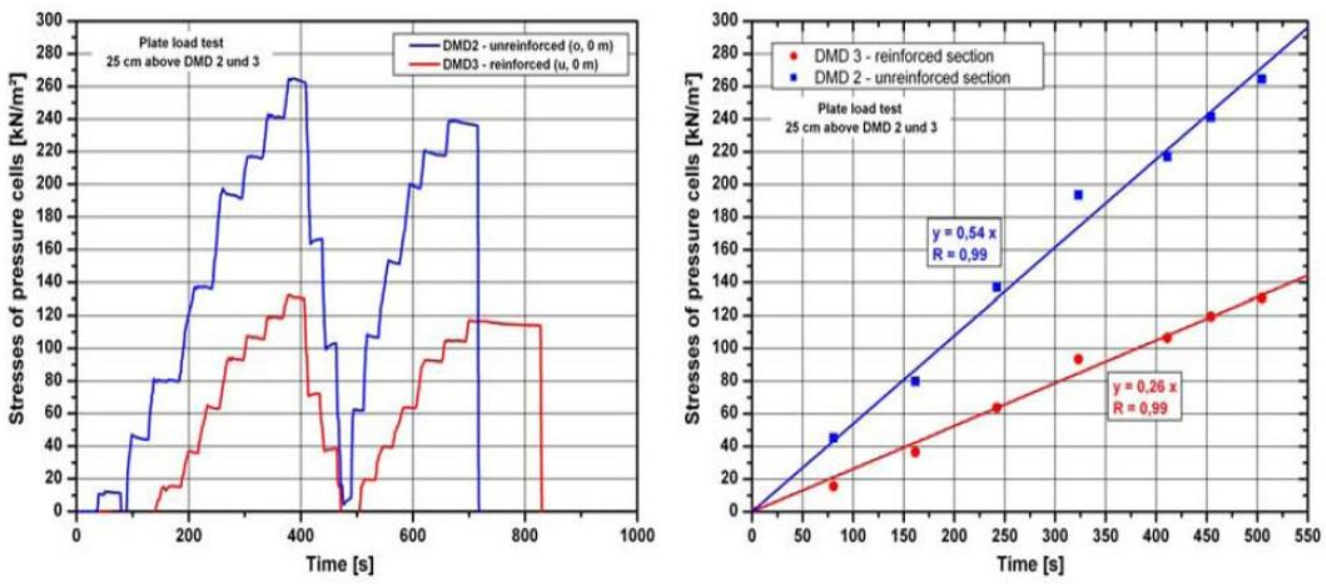

Figure 2. 15 Graph of loading results as recorded by pressure cells DM2-DM3 (dynamic-left \& static-right) (Kief et al. 2008)

Results discussed in the research show individual heavy-truck passages over the geocell reinforced and unreinforced areas. The data shows a $23-28 \%$ performance increase with the addition of geocells to the pavement system. 
The properties of the geocell were examined for better understanding of the phenomena that occurs within the cells. The cells are three-dimensional structures that typically consist of patterned protuberances. Composite system is created when granular fill material is confined with the geocells. The cellular confinement increases the mechanical and physical properties, and this results in higher lateral stresses and resistance on the cell walls. This also decreases punching of the soil, increases the soils bearing capacity, and reduces settlement (Figure 2.16).

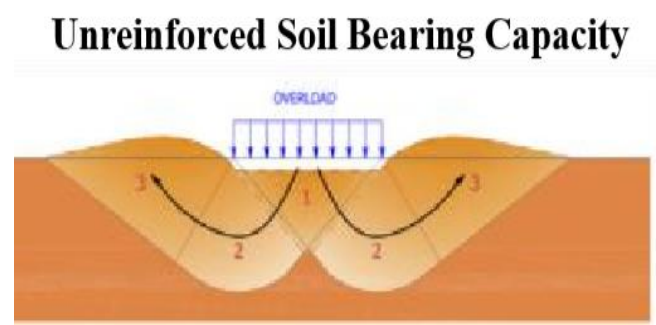

(a)
Reinforced Soil Bearing Capacity

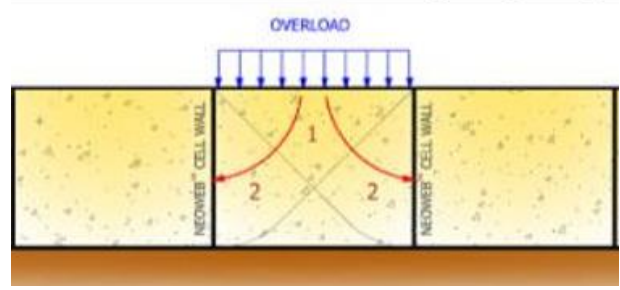

(b)

Figure 2. 16 (a) Shear punching with no reinforcement (b) confinement decreases punching and increases bearing capacity (Kief et al. 2008)

The observed lateral stresses induce an increase in the shear strength. By limiting lateral displacement, high hoop strength can be observed within the structure. These horizontal stresses applied on the loaded cell walls between the soil and infill can increase interlayer friction resistance ability.

\section{Conclusion:}

Geocells can potentially allow for less excavation, haul, and material infill, and it can provide economic and environmental benefits. The road serviceability can further be prolonged which enables construction of new roadway systems instead of maintenance and repair of existing roads. This technology helps for roadway enhancement in areas exposed to seasonal weather changes and rural environments.

\subsubsection{Advantages of Mechanical Concrete Road Over Conventional Road (Chakrey and Pawar, 2015)}

\section{Introduction:}

Mechanical concrete is an environmental methodology for advancements in road construction techniques. Mechanical concrete is manufactured using cylinders, made from 
stripped-walled tires, to confine stone aggregates in an attempt to increase load bearing capacity. Chakrey and Pawar (2015) compare the overall advantages of utilizing mechanical concrete in roadways over conventional systems. Many roadway failures can be attributed to extensive lateral pressures being unevenly distributed within unconfined aggregates in conventional road systems. The main objective of using Mechanical Concrete Road (MCR) is to achieve economic benefits by the utilization of recyclable materials, mitigation of maintenance costs, and minimization of construction time for roadway development.

\section{Methodology:}

Sites should be first prepared for time derived cylinder (TDC) installment. Mechanical Concrete Road comprises of TDCs. TDCs are laid adjacent to one another on the subgrade layer. Nail guns can be utilized as a means for connecting the tires to one another. Each TDC should be in contact with three other TDCs for support mechanism. Aggregates can then be poured over top of the TDCs without compaction.

The process on which the cylinders work is based on similar principles of the geocells. The aggregates transfer the main load downwards along the axis of the cylinder to the earth, and they transfer lateral pressures to the cylindrical device which resists hoop stress. The TDC, or mechanical concrete road structure, performs comparable to cement due to its unique ability to act as a binder when confining the aggregate filler material.

\section{$\underline{\text { Results: }}$}

Table 2.6 displays the construction activities for installation of both conventional and mechanical concrete reinforced roadways. The overall time frame for both methodologies can be compared in Figure 2.17. However, this timeframe is subject to material availability and location. This shows a graphical representation of the construction activity chart for $1 \mathrm{~km}$ by $12 \mathrm{~m}$ roadway. The reduction of time and money is relative to the road specifications laid down by the Indian Road Congress. 
Table 2. 6 Activity sheet for time comparison in construction of MCR and conventional road (in hrs.) (Chakrey and Pawar, 2015)

\begin{tabular}{|c|c|c|c|c|c|c|c|}
\hline \multicolumn{4}{|c|}{ Conventional Road } & \multicolumn{4}{|c|}{ Mechanical Concrete Road (MCR) } \\
\hline Item & $\begin{array}{c}\text { Activity } \\
\text { Description }\end{array}$ & $\begin{array}{l}\text { Time } \\
\text { (hrs.) }\end{array}$ & $\begin{array}{l}\text { Cumulative } \\
\text { Time (hrs.) }\end{array}$ & Item & $\begin{array}{c}\text { Activity } \\
\text { Description }\end{array}$ & $\begin{array}{l}\text { Time } \\
\text { (hrs.) }\end{array}$ & $\begin{array}{l}\text { Cumulative } \\
\text { Time (hrs.) }\end{array}$ \\
\hline 1 & $\begin{array}{c}\text { Forming } \\
\text { alignment using } \\
\text { Total Station }\end{array}$ & 1 & 1 & 1 & $\begin{array}{c}\text { Forming } \\
\text { alignment using } \\
\text { Total Station }\end{array}$ & 1 & 1 \\
\hline 2 & $\begin{array}{l}\text { Marking various } \\
\text { lengths on road }\end{array}$ & 1.5 & 2.5 & 2 & $\begin{array}{l}\text { Marking various } \\
\text { lengths on road }\end{array}$ & 1.5 & 2.5 \\
\hline 3 & $\begin{array}{c}\text { Excavation of } \\
\text { road to required } \\
\text { grade }\end{array}$ & 15 & 17.5 & 3 & $\begin{array}{c}\text { Excavation of } \\
\text { road to required } \\
\text { grade }\end{array}$ & 12 & 17.5 \\
\hline 4 & $\begin{array}{l}\text { Compaction of } \\
\text { subgrade }\end{array}$ & 2 & 19.5 & 4 & $\begin{array}{l}\text { Compaction of } \\
\text { subgrade }\end{array}$ & 0 & 17.5 \\
\hline 5 & $\begin{array}{l}\text { Laying of sub } \\
\text { base with } \\
\text { compaction }\end{array}$ & 6 & 25.5 & 5 & Laying of tires & 4 & 21.5 \\
\hline 6 & $\begin{array}{c}\text { Laying of base } \\
\text { with compaction }\end{array}$ & 5 & 30.5 & 6 & Rivet Tires & 4 & 25.5 \\
\hline 7 & $\begin{array}{l}\text { Laying of water } \\
\text { bound macadam }\end{array}$ & 8 & 38.5 & 7 & $\begin{array}{l}\text { Laying of filler } \\
\text { material in tires }\end{array}$ & 6 & 31.5 \\
\hline 8 & Hold & 24 & 62.5 & 8 & $\begin{array}{c}\text { Laying of prime } \\
\text { coat }\end{array}$ & 3 & 34.5 \\
\hline 9 & $\begin{array}{c}\text { Laying of prime } \\
\text { coat }\end{array}$ & 3 & 65.5 & 9 & $\begin{array}{c}\text { Laying of } \\
\text { bituminous mix }\end{array}$ & 4 & 38.5 \\
\hline 10 & $\begin{array}{c}\text { Laying of } \\
\text { bituminous mix }\end{array}$ & 4 & 69.5 & 10 & $\begin{array}{c}\text { Compaction of } \\
\text { top surface using } \\
\text { a roller }\end{array}$ & 5 & 43.5 \\
\hline 11 & $\begin{array}{c}\text { Compaction of } \\
\text { top surface using } \\
\text { a roller }\end{array}$ & 5 & 75.5 & 11 & Ready for use & 0.5 & 44 \\
\hline 12 & Ready for use & 24 & 98.5 & - & - & - & - \\
\hline
\end{tabular}




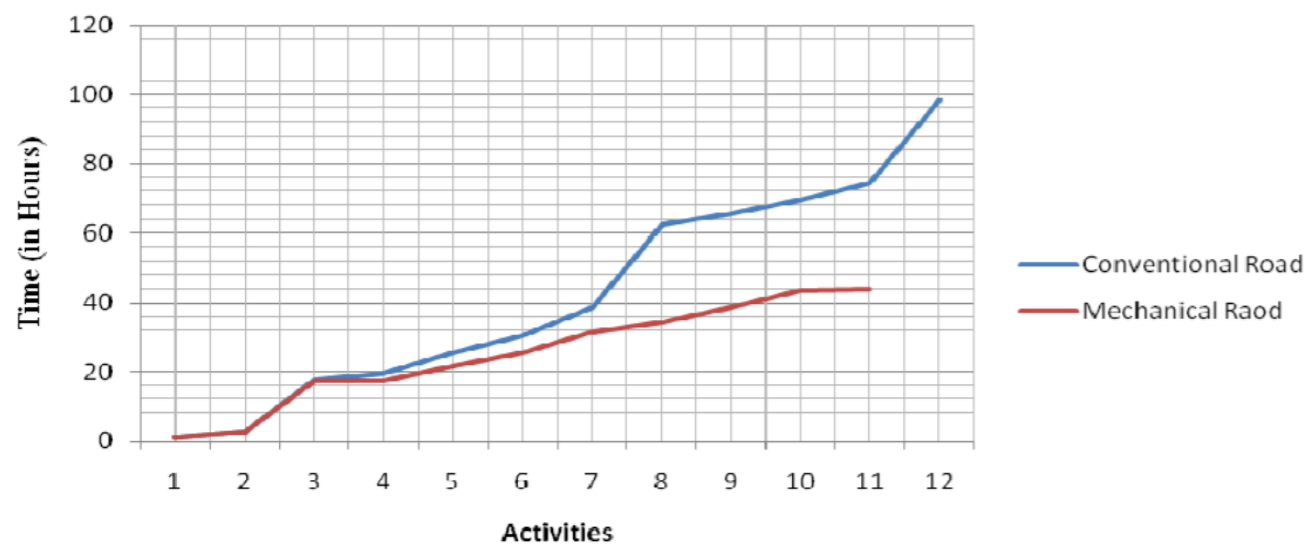

Figure 2. 17 Graphical representation of activity chart (Chakrey and Pawar, 2015)

\section{Conclusions:}

Mechanical concrete in the construction of roadway systems has the potential to reduce installation time, minimize material costs, and provides durability due to aggregate confinement within the cylindrical tires. MCRs could potentially decrease maintenance and repair costs as they can drain off rain waters with increased void ratio. Research estimates $27 \%$ cost reduction with utilization of mechanical concrete systems as per District Scheduled Rates, and therefore, expanded studies need to be performed.

\subsection{Conclusions}

This literature review was aimed to further increase our understanding of pavement failure modes and discuss current reinforcement products used in base/ sub base systems for paved and unpaved roads. Based on the review, testing scenarios, load frequencies, testing styles, areas of emphasis, material selection, etc., applicable parameters were selected for this research work. Soil and base/sub base reinforcement can extend the overall life of a pavement system. Traditional road installation methods may not be viable in some instances, and therefore, alternative methodologies can be implemented to increase pavement performance. This research intends to compare performance of pavement sections reinforced with tire-derived geo-cylinders (mechanical concrete) and geo-polymer (geosynthetic) products. Mechanical concrete, geotextiles, geowebs, and geogrids in the construction of roadway systems have the potential to reduce installation time and minimize material costs compared to conventional roadway practices. 


\section{MATERIALS AND TEST PROCEDURE}

This chapter describes the materials and applicable test procedures used in this study including American Society for Testing and Materials (ASTM), West Virginia Division of Highways (WVDOH) Standards, and American Association of State Highway and Transportation Officials (AASHTO) guidelines.

\subsection{Materials}

This section discusses materials utilized for testing including the construction of large and small wooden test bins to replicate representative pavement (roadway) sections.

\subsubsection{Lab Roadway Set-up}

The following section describes the construction of a 7'x12' (Large Bin) and a 4'x 6' bin (Small Bin) using timber sections. Different layers of pavement sections including subgrade, subbase and base layers were replicated in test bins. Base and subbase layers were reinforced with different types of woven geotextiles, geogrids, geowebs, and tire-derived geo-cylinders.

A test bin replicating the field cross-section was necessary to evaluate the effectiveness of woven geotextiles, geogrids, geowebs, and TDGCs used for strengthening pavement properties. Various stages of representative test bin ( $\left.7^{\prime} \times 12^{\prime}\right)$ construction are shown in Figure 3.1.

Pavement representative sections also referred to as the roadway sections in the wooden bins were constructed using 2" x 10 " dimension lumber and reinforced with appropriate vertical and angle bracing schemes to support the placement of infill materials and subsequent load applications. The interior of the constructed bin was lined with heavy duty polyethylene sheeting. The large bin was filled with soil using a skid steer and compacted three 6-inch lifts. Following each subsequent soil lift, a vibratory plate compactor was used to ensure compaction of the subgrade. The large bin was tested with a relatively lower degree of compaction and the small bin was tested with a comparatively higher degree of compaction as per AASHTO 204.11 (C). A woven geotextile separation fabric was placed on top of the soil subgrade layer and TDGCs. The TDGCs were placed uniformly throughout the bin over the separation fabric. Aggregate was then placed in the bin via a skid steer to fill the hollow spaces within and around the TDGC. Then aggregates were smoothed out with garden tools to a depth of approximately 1-2 inches above the top surface of the TDGC. The small bin with dimensions of 4'x6' was built in a similar fashion. 


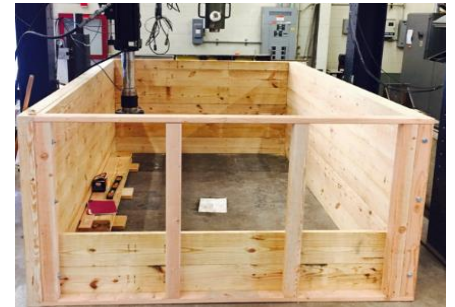

(a)

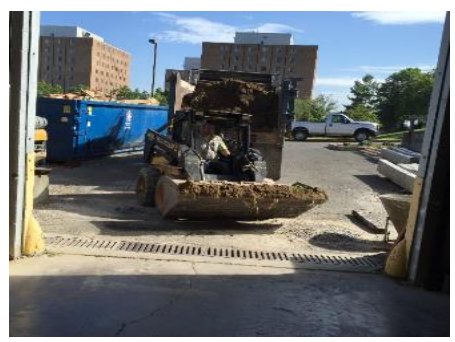

(c)

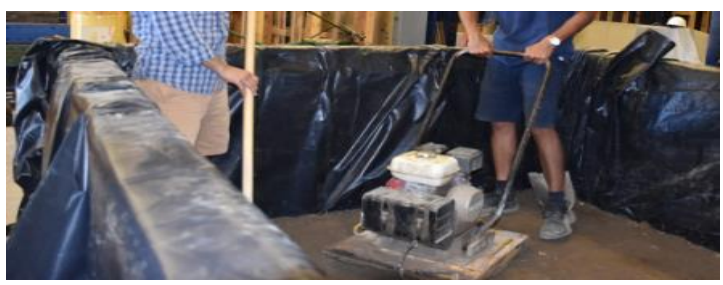

(e)

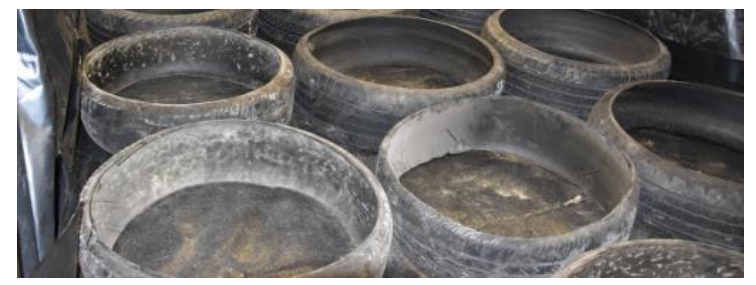

(g)

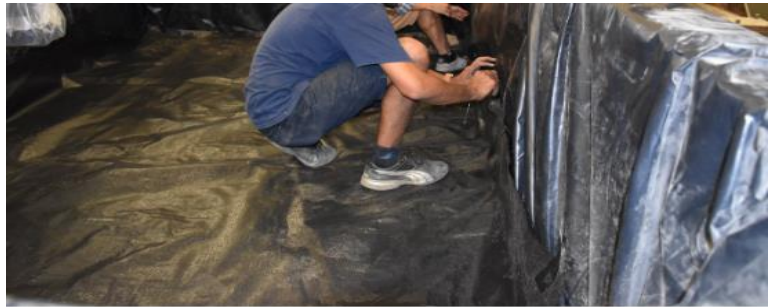

(b)

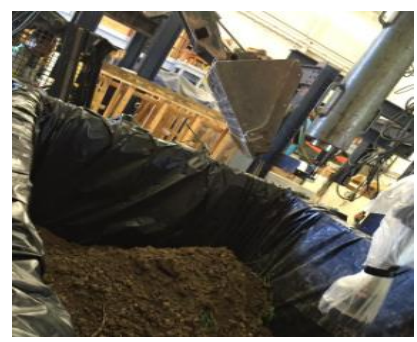

(d)

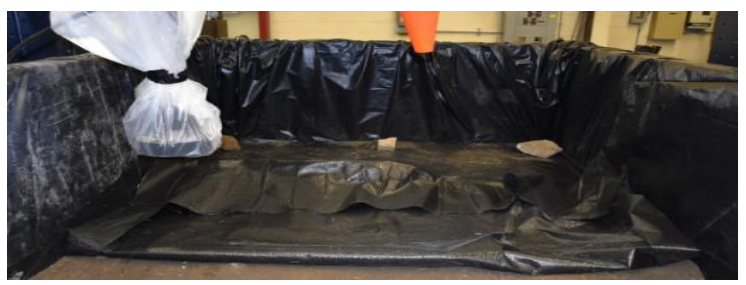

(f)

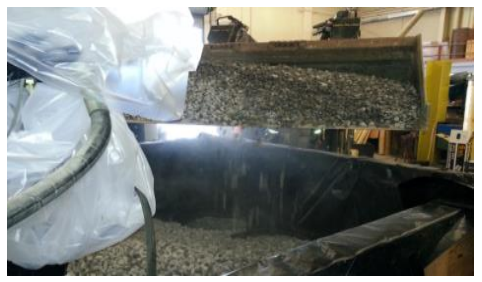

(h)

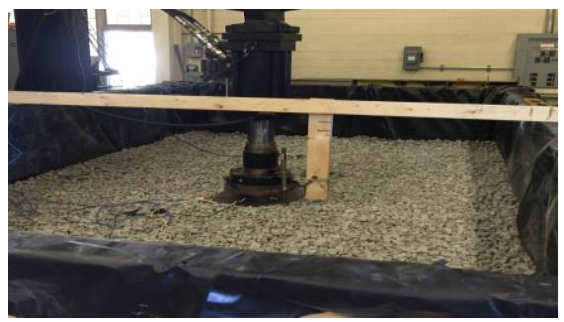

(i)

Figure 3. 1 Large bin construction (a) built the bin's frame (b) covering of interior bin surface with polyethylene sheeting (c) moving of soil via skid steer (d) placement of soil in the test bin (e) compacted soil in three 6-inch lifts (f) placement of separation woven geotextile fabric on the soil subgrade (g) placement of TDGCs $(\mathrm{h})$ placement of AASHTO \#57 aggregate as infill for the TDGCs (i) leveling of the aggregate prior to testing. 
The final pavement representative (roadway) section test bins are shown in Figure 3.2. Static and fatigue tests were conducted with woven geotextiles, geogrids, geowebs, and TDGCs with the use of these roadway sections.

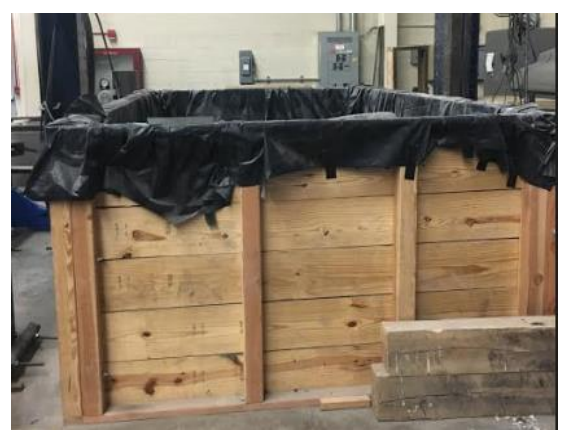

(a)

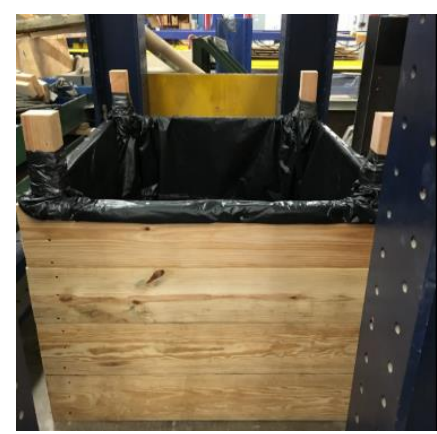

(b)

Figure 3. 2 Test bins (a) large (7’x12') bin (b) small (4'x6') bin

\subsubsection{Laboratory Soil Testing}

The soil used as a subgrade material during this research was obtained locally from the West Virginia University Physical Plant. From the Web Soil Survey data of the NRCS and United States Department of Agriculture (USDA), soil information was obtained for Monongalia County, West Virginia. The data showed that roughly $26 \%$ or more of the soil located in Monongalia County is silty sandstone. A soil meeting similar parent material was used in both bins during testing.

Some of the tests performed on the soil specimens include: Atterberg Limits, Sieve Analysis, Specific Gravity, and Nuclear Gauge tests. Experiments were conducted in the laboratory to classify the soil.

Laboratory experiments included the calculation of Atterberg Limits (ASTM D4318) for the soil specimen. Atterberg limits provided the measure of the soil's critical water content. The liquid limit (point at which the tested soil begins to behave as a liquid) was graphed to display the trend lines' relationship to the optimum amount of 25 drops for soil testing. Summary of Atterberg Limits are presented in Figure 3.3 and summarized in Table 3.1. 


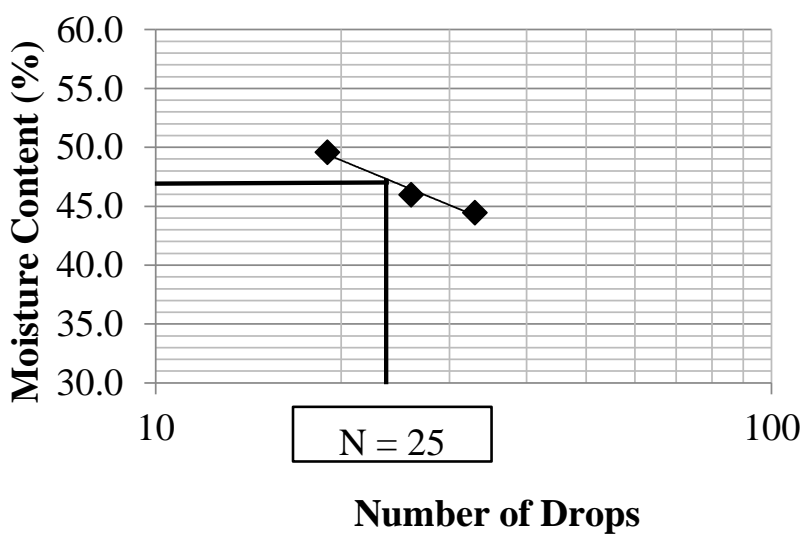

(a)

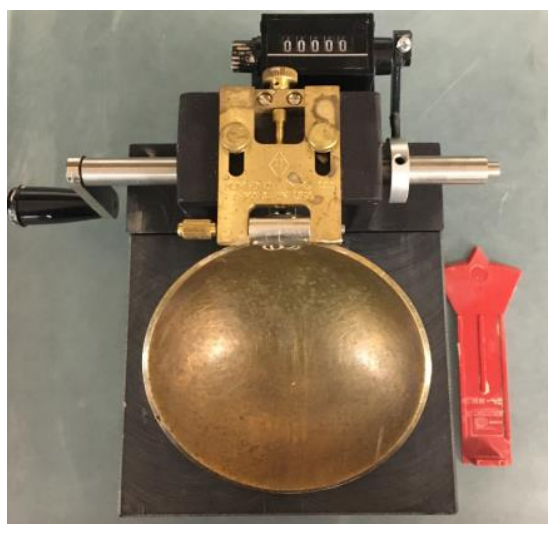

(b)

Figure 3. 3 Atterberg limit testing (a) moisture content for subgrade soil specimen used in the test bins (b) casagrande cup and flat grooving tool

Table 3. 1 Atterberg limit summary

\begin{tabular}{|c|c|}
\hline \multicolumn{2}{|c|}{ SM-Silty Sand } \\
\hline Liquid Limit (LL) & 47 \\
\hline Plastic Limit (PL) & 30 \\
\hline Plasticity Index (PI) & 17 \\
\hline
\end{tabular}

Following the Atterberg Limit testing, data was plotted corresponding to the activity line, "A" Line. Knowing the Plasticity Index (measure of plasticity in the tested soil specimen) and the Liquid Limit (point at which the soil begins to behave as a liquid), the soil was observed to fall below the "A" Line. The "A" Line is a sloped line that begins at Plasticity Index $=4$ and Liquid Limit $=25.5$. The lines' trend is represented by the formula: 0.73 (LL-20). Figure 3.4 was plotted with respect to the Unified Soil Classification System’s (USCS) Plasticity Chart.

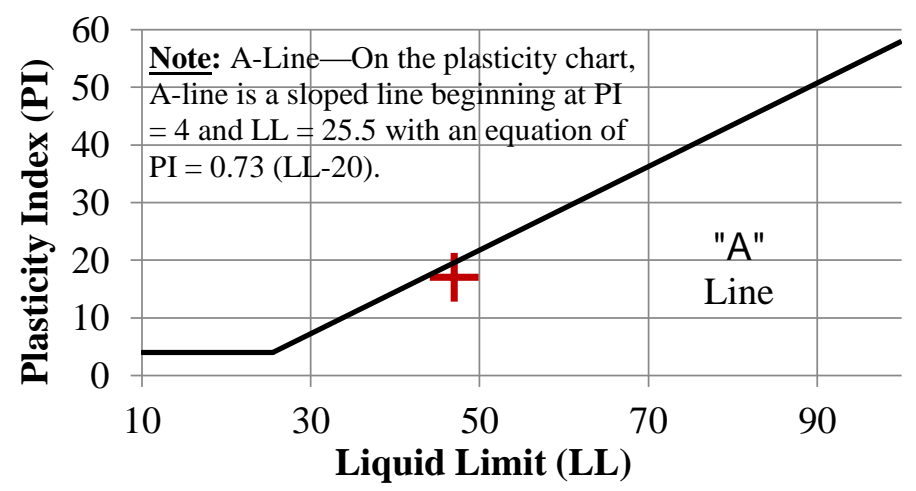

Figure 3. 4 Plasticity Chart for in-situ soil, "A" Line 
To further characterize the soil composition, a grain size distribution was plotted. The grain size distribution analysis test incorporated all necessary sieves pertaining to (ASTM D422) to determine the distribution of particle sizes present in the tested soil specimen. Figure 3.5 shows the sieve set-up for testing.

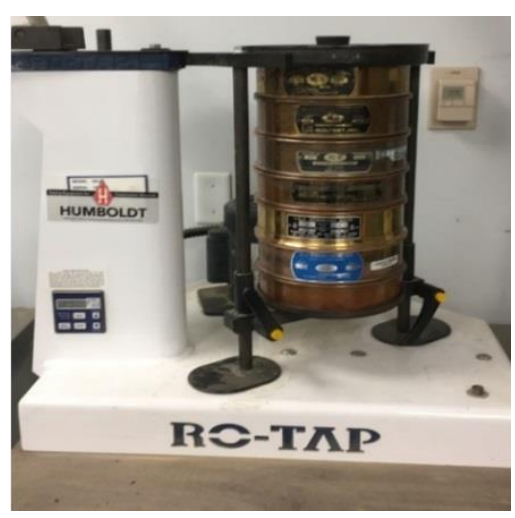

(a)

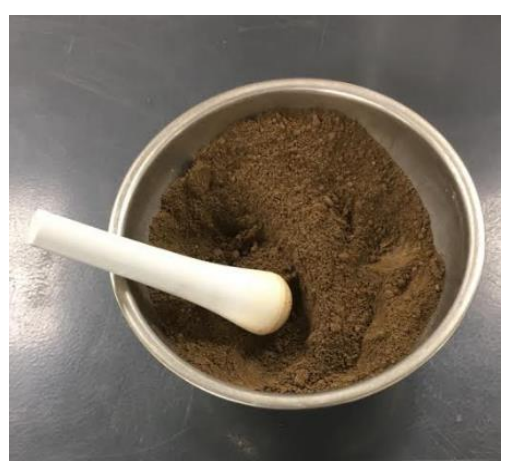

(b)

Figure 3. 5 Sieve analysis laboratory display of equipment (a) W.S. Tyler (Ro-Tap) sieve shaker with sieves (b) mortar and pestle

Utilizing the sieves (sizes pre-determined from AASHTO), sieve shaker, and mortar and pestle, a grain size distribution curve was plotted to represent the percentage of passing particles (Figure 3.6). The curve obtained from sieve analysis suggests a well-graded soil for the soil specimen used in both the large and small test bins (Bowles, 1988).

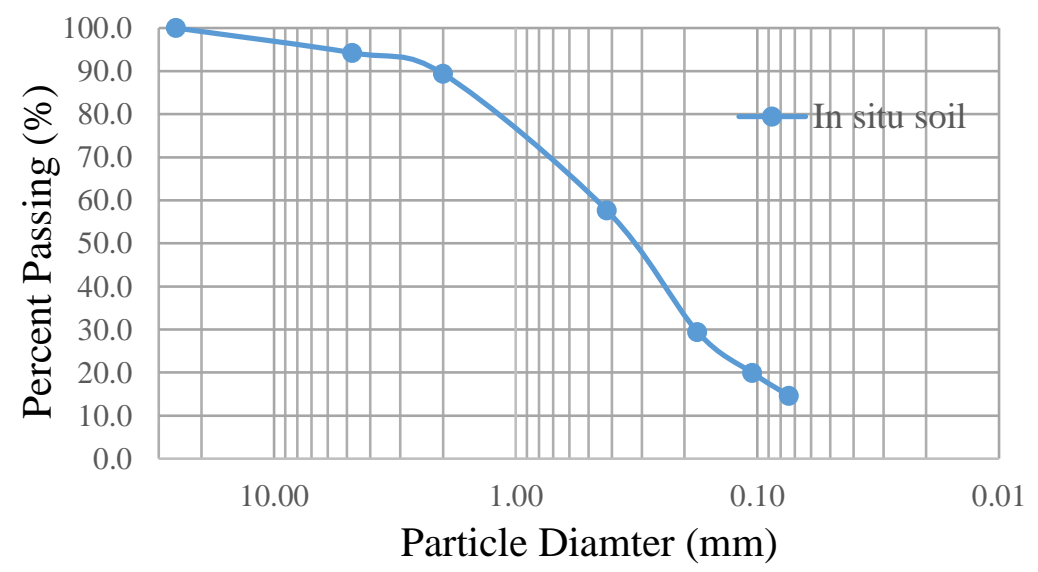

Figure 3. 6 Grain size distribution of soil used in large and small test bin to represent pavement subgrade 
Laboratory testing on the in-situ (subgrade) soil specimen, also included a specific gravity test. The test was based on ASTM D854 - Method B which specifies the use of an oven-dried specimen for the procedure. Specific Gravity at a given temperature is calculated from Equation 3.1.

$$
G_{t}=\frac{\rho_{s}}{\rho_{w, t}}=\frac{M_{s}}{M_{\rho w t}-\left(M_{\rho w s, t}-M_{s}\right)}
$$

Where:

$\rho_{\mathrm{s}}=$ the density of the soil solids $\mathrm{Mg} / \mathrm{m}^{3}$ or $\mathrm{g} / \mathrm{cm}^{3}$

$\rho_{\mathrm{w}, \mathrm{t}}=$ the density of water at the test temperature, $\mathrm{g} / \mathrm{mL}$ or $\mathrm{g} / \mathrm{cm}^{3}$

$\mathrm{M}_{\mathrm{s}}=$ the mass of the oven dry soil solids ( $\mathrm{g}$ )

$\mathrm{M}_{\rho \mathrm{ws}, \mathrm{t}}=$ the mass of pycnometer, water, and soil solids at the test temperature, $\mathrm{g}$

The soil was tested with the pycnometer as per ASTM standards and the air was removed from the soil as shown in Figure 3.7.
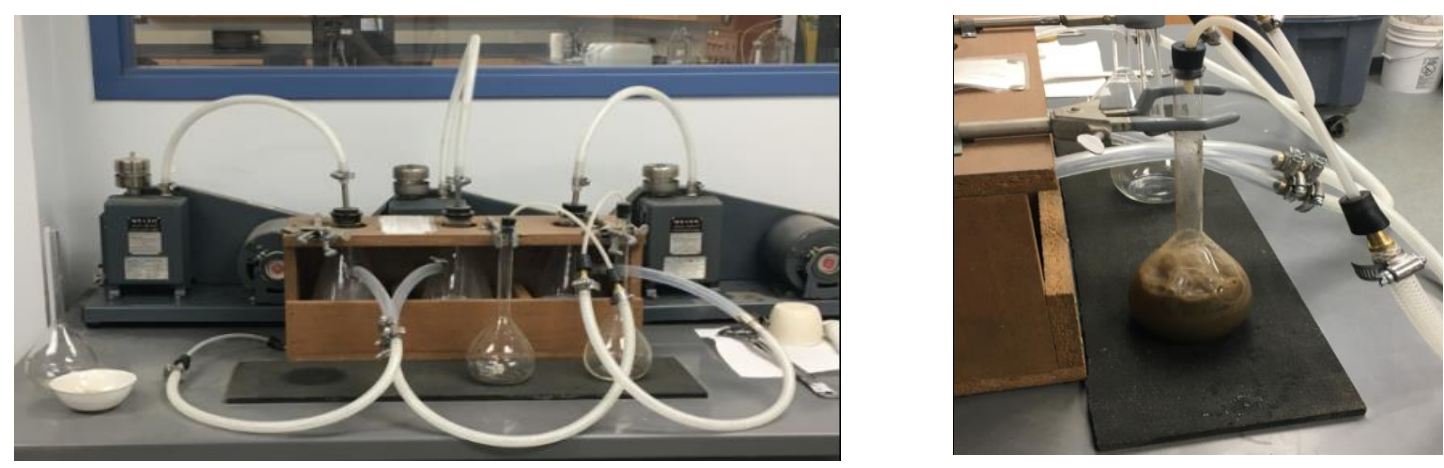

Figure 3. 7 Specific gravity testing of the subgrade soil specimen (a) pycnometer used for soil testing (b) air being withdrawn from the soil specimen.

Soil tests were also conducted on the in-situ soil subgrade (soil) materials placed and compacted in the large and small test bins as described earlier in Section 3.1.1. The Nuclear Gauge Tests were conducted at different locations of each test bin. The locations are shown in Figure 3.8. The large test bin represented a soil condition with a lower degree of compaction whereas the small test bin reflected a relatively high degree of soil compaction (approximately 93\%). 

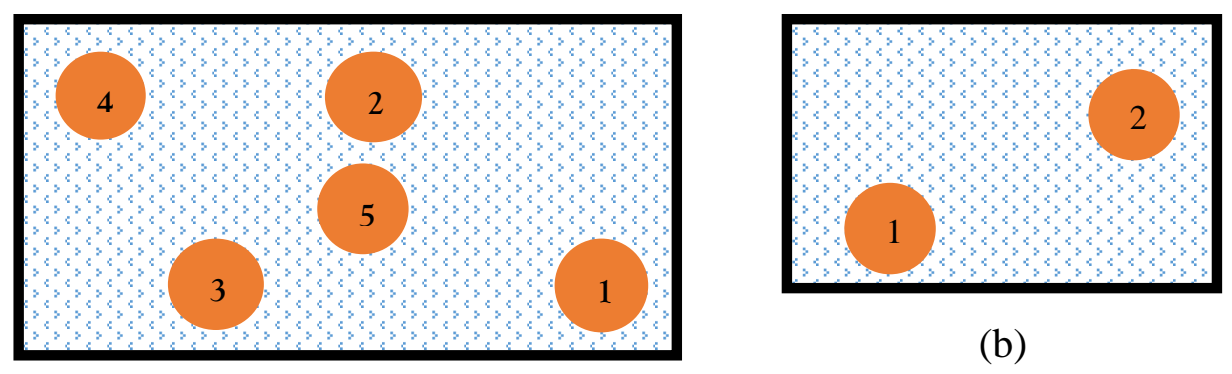

(b)

(a)

Figure 3. 8 Nuclear gauge testing locations

(a) large bin tested locations (b) small bin tested locations

The in-situ (original soil subgrade) test was performed in the laboratory to determine the density of the subgrades. The non-destructive technique using nuclear density gauge was used as per ASTM D6938 to determine the in-situ density. Nuclear gauge testing (Figure 3.9) provides information on the density and moisture content of the subgrade material used in this study within the large and small test bins.

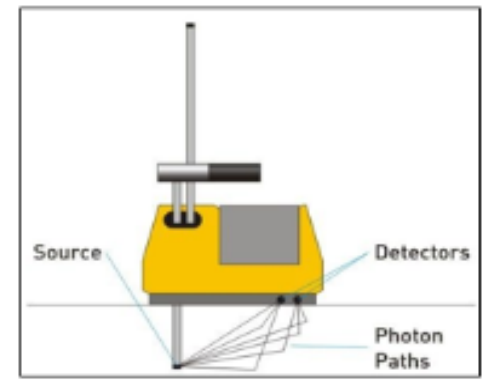

(a)

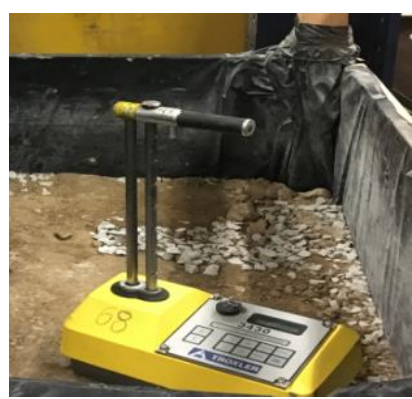

(b)

Figure 3.9 Nuclear gauge testing of subgrade soil in large and small test bins (a) overview of nuclear gauge (b) nuclear gauge testing in the constructed bins

The nuclear gauge device consists of a radiation source that emits photon particles and a sensor that counts the received particles, reflected by the test material. By calculating the percentage of photon particles that return to the sensor, the gauge is calibrated to measure the wet density and moisture content of the test material. Before inserting a probe consisting a source into the test material, a hole is pre-made into the material (Figure 3.9a). The test can be performed with 2 " to 12 " long probe, but the pre-made hole always has to be 2 " deeper than the probe length used. In this test, the probe length was kept at 6" for aggregate testing and 12" for soil testing. Data obtained from nuclear gauge testing the large and small bins are provided in Table 3.2 and Table 3.3. 
Table 3. 2 Density and moisture data acquired from nuclear gauge testing of soil specimen in large bin

\begin{tabular}{|c|c|c|c|c|c|}
\hline & S1 & S2 & S3 & S4 & S5 \\
\hline Dry density (pcf) & 73.5 & 78.3 & 77.7 & 72.0 & 86.6 \\
\hline Wet density (pcf) & 94.4 & 98.3 & 99.2 & 94.6 & 99.7 \\
\hline \% Moisture & $28.4 \%$ & $25.6 \%$ & $27.7 \%$ & $31.4 \%$ & $15.1 \%$ \\
\hline
\end{tabular}

Table 3. 3 Density and moisture data acquired from nuclear gauge testing of soil specimen in small bin

\begin{tabular}{|c|c|c|}
\hline & S1 & S2 \\
\hline Dry density (pcf) & 103.0 & 111.5 \\
\hline Wet density (pcf) & 112.3 & 125.4 \\
\hline \% Moisture & $9.0 \%$ & $12.5 \%$ \\
\hline
\end{tabular}

Based on the test data and as per American Society of Testing and Materials (ASTMD2487), the soil specimen used in our laboratory test bins is classified and characterized as a SM, silty-sand with a specific gravity of 2.67. Though no specific permeability testing was conducted in this study, the permeability range for an SM-soil specimen is $10^{-5} \mathrm{~m} / \mathrm{s}$ to $10^{-9} \mathrm{~m} / \mathrm{s}$ (Bowles, 1988).

\subsubsection{Geo-polymer Material Properties}

Various geo-polymer materials used within the representative pavement sections for strength base/sub base strengthening are described in this section. These geo-polymers were used for either separation of layers or base/sub base strengthening. These materials include: (i) reinforcement woven geotextile (ii) geogrid (iii) 6 inch geowebs (geocells), and (iv) 8 inch geowebs (geocells).

\section{Separation Woven Geotextile}

A woven geotextile was used as a separator between the soil layer and aggregates (Figure 3.10). The separation woven geotextile was used in all of the test cases. The separation woven geotextile has low strength properties because its main purpose is to act as a separator only. The woven fabric (Figure 3.10) consisted of $100 \%$ polypropylene silt film yarns and is described by the manufacturer to have ultraviolet and biological degradation properties, ability to prevent rotting, and stability in soils with $\mathrm{pH} 2-13$. Tensile strength of the fabric is $200 \mathrm{lbs}$. with $15 \%$ elongation. 


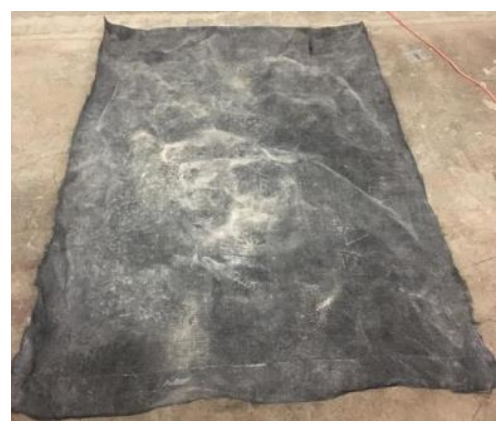

(a)

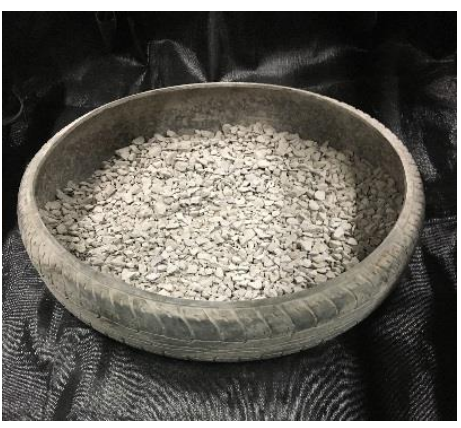

(b)

Figure 3. 10 Separation woven fabric (a) fabric used on top the subgrade for the large and small test bins (b) a TDGC placed on top of the separation woven geotextile fabric

\section{Woven Geotextile}

The woven geotextile (Figure 3.11) fabric is made of polypropylene and helps in providing tensile strength, stabilization, and drainage. Key properties of the woven geotextiles include ultraviolet resistance, biological resistance, rotting resistance, and sufficient resistance to $\mathrm{pH}$ levels in soil. Its tensile strength at $2 \%$ strain is $540 \mathrm{lb} / \mathrm{ft}$. The woven geotextile was used in the small testing bin during fatigue testing (1-4 kip at $2 \mathrm{~Hz}$ ) described in Chapter 4.

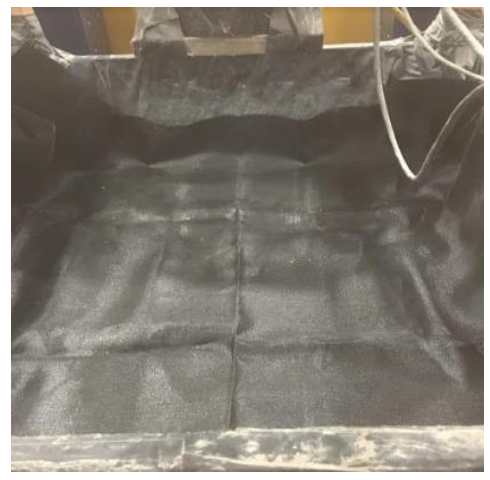

Figure 3. 11 Reinforcement woven geotextile utilized for base/sub base support

Woven geotextile strips were tested in tension. Summary tension tests on the geotextile strips are provided in Table 3.4.

Table 3. 4 Summary of woven geotextile tension tested specimens

\begin{tabular}{|c|c|c|c|c|c|}
\hline Specimen & Thickness & Width (in) & Area $\left(\right.$ in $\left.^{2}\right)$ & $\begin{array}{c}\text { Stress } \\
(\mathrm{psi})\end{array}$ & $\begin{array}{c}\text { Modulus (E) } \\
(\mathrm{psi})\end{array}$ \\
\hline 1 & 0.024 & 1.0175 & 0.024 & 8,200 & 143,400 \\
\hline 2 & 0.024 & 1.0635 & 0.026 & 6,745 & 110,000 \\
\hline Averages & - & - & - & $\mathbf{7 , 5 0 0}$ & $\mathbf{1 2 6 , 0 0 0}$ \\
\hline
\end{tabular}


From tensile testing the woven geotextile specimens (Figure 3.12), the average maximum stress $\left(\sigma_{\text {ave,max }}\right)$ was approximately 7,500 psi and average modulus of elasticity $\left(\mathrm{E}_{\text {ave }}\right)$ was $126 \mathrm{ksi}$ at $2 \%$ strain.

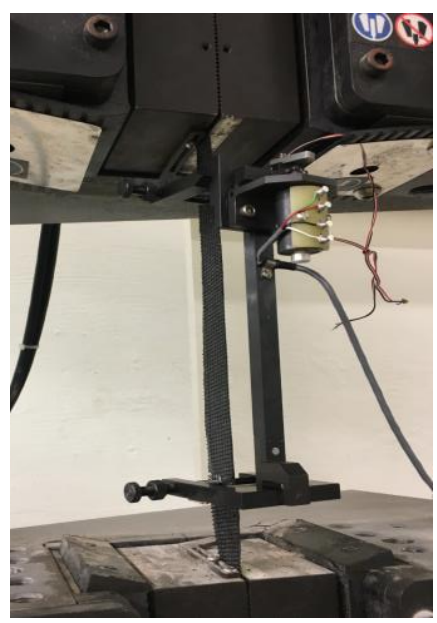

(a)

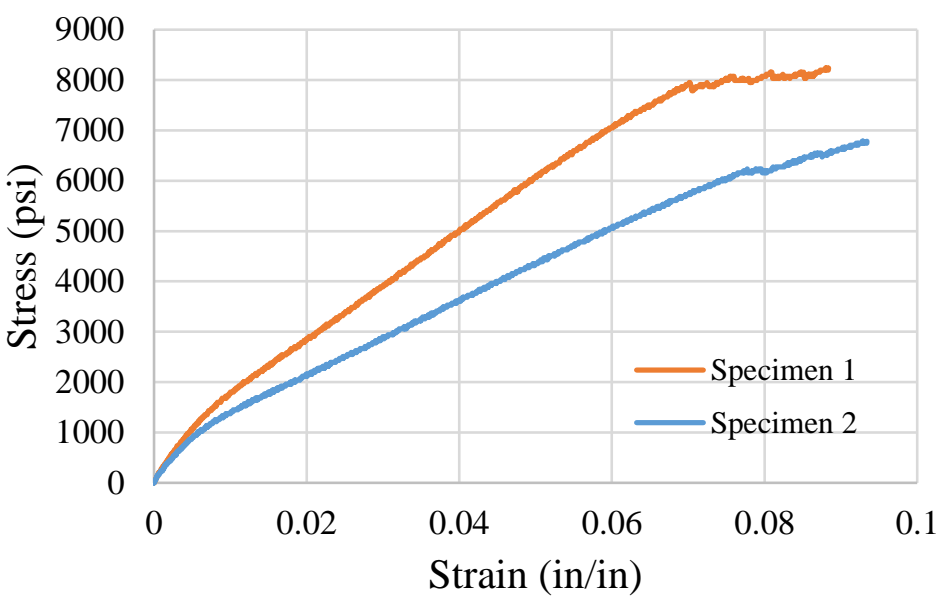

(b)

Figure 3.12 Tensile test results of the woven geotextile specimens (a) laboratory set-up during testing (b) stress vs. strain relationship

$\underline{\text { Geogrid }}$

Geogrid is a type of geo-polymer in which a grid pattern is developed from longitudinal and transverse placement of polypropylene materials. The bi-axial grid used in this research (Figure 3.13) can serve the primary function of reinforcement in the base and/or subgrade and also stabilization. At $2 \%$ strain, tensile strength of geogrid is $280 \mathrm{lb} / \mathrm{ft}$. in the longitudinal direction, and $450 \mathrm{lb} / \mathrm{ft}$. in the transverse direction.

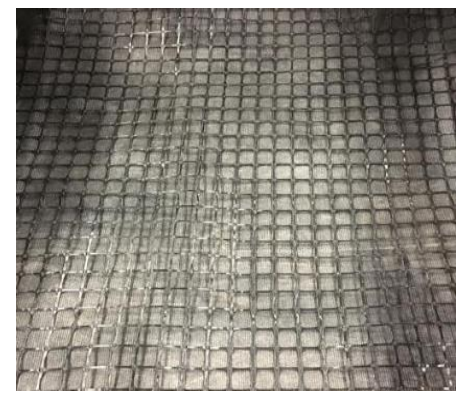

Figure 3. 13 Geogrid specimen utilized for base/sub base support 
The geogrid is patterned bi-axially; therefore, the tensile specimens were tested in tension to examine the strength of the geogrid. Dimensions of the specimens utilized in tension testing are provided in Table 3.5.

Table 3.5 Summary of woven geotextile tension tested specimens

\begin{tabular}{|c|c|c|c|c|c|}
\hline Specimen & Thickness & Width (in) & Area $\left(\mathrm{in}^{2}\right)$ & $\begin{array}{c}\text { Stress } \\
(\mathrm{psi})\end{array}$ & $\begin{array}{c}\text { Modulus (E) } \\
(\mathrm{psi})\end{array}$ \\
\hline 1 & 0.034 & 0.236 & 0.008 & 24,000 & 500,000 \\
\hline 2 & 0.034 & 0.236 & 0.008 & 25,800 & 500,000 \\
\hline Average & - & - & - & $\mathbf{2 5 , 0 0 0}$ & $\mathbf{5 0 0 , 0 0 0}$ \\
\hline
\end{tabular}

From tensile testing of the geogrid biaxial specimens (Figure 3.14), the average maximum stress $\left(\sigma_{\mathrm{ave}, \max }\right)$ was $25 \mathrm{ksi}$ and average modulus of elasticity $\left(\mathrm{E}_{\mathrm{ave}}\right)$ was $500 \mathrm{ksi}$ at $2 \%$ strain.

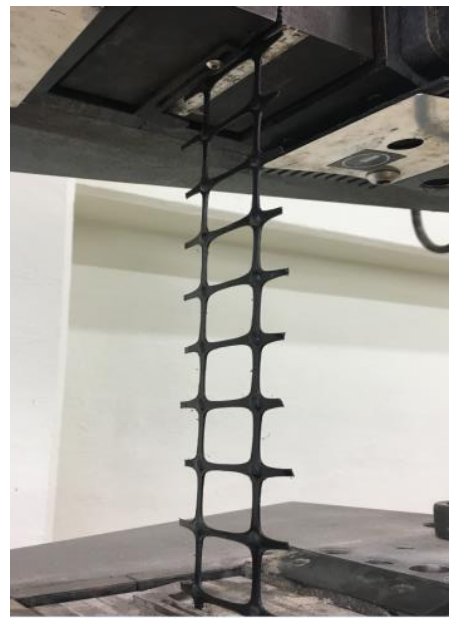

(a)

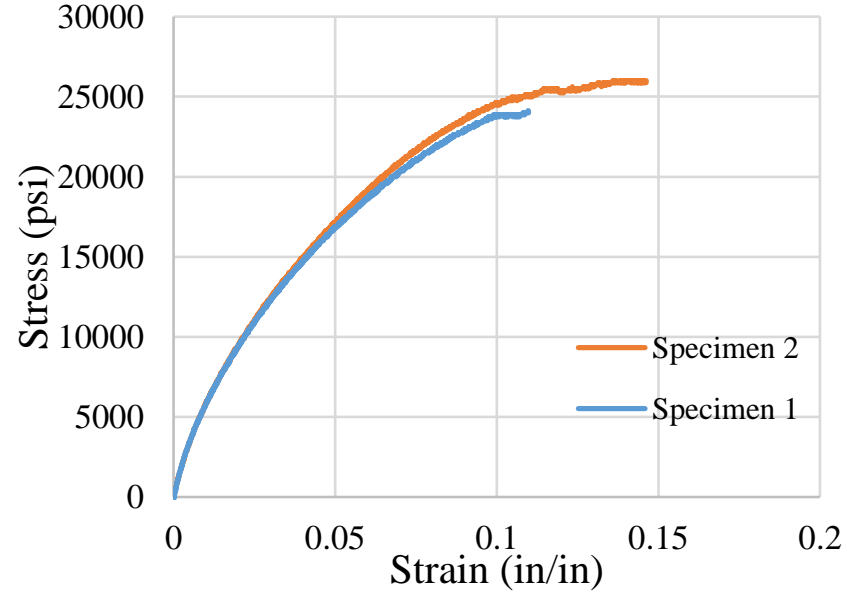

(b)

Figure 3. 14 Tensile test results of the geogrid specimens

(a) laboratory set-up during testing (b) stress vs. strain relationship

$\underline{\text { Geoweb, or Geocell }}$

Geoweb or Geocell is another type of geo-polymer (geosynthetic material) evaluated. Geoweb was used in the pavement representative sections (roadway) for reinforcing the base/sub base layers. The geowebs were evaluated through static loading and sinusoidal fatigue loading conditions for low loading and high loading scenarios. The two types of geowebs used in this study consisted of two separate heights of 6 inches and 8 inches. The honey-comb shaped cells with a nominal expanded cell area of $71.3 \mathrm{in}^{2}$ are manufactured from extruded high density polyethylene 
(HDPE) strips. The cells are three dimensional and enhance the soil moduli and load capacity through confinement effects (Figure 3.15).

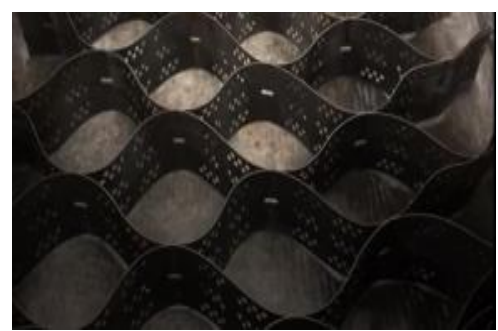

(a)

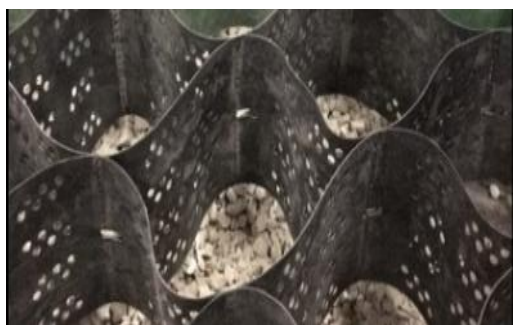

(b)

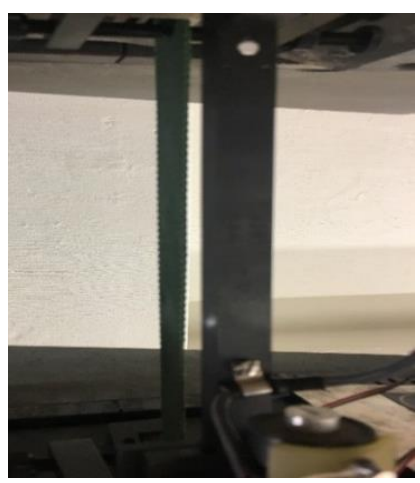

(c)

Figure 3.15 Geoweb materials with varying depths (a) 6 inch geoweb (b) 8 inch geoweb (c) tensile testing of HDPE geoweb strips

Dimensions for each specimen are provided in Table 3.6. The obtained data are plotted and shown in Figure 3.16.

Table 3. 6 Summary of geoweb tension tested specimens

\begin{tabular}{|c|c|c|c|c|c|}
\hline Specimen & Thickness & Width (in) & Area $\left(\mathrm{in}^{2}\right)$ & $\begin{array}{c}\text { Stress } \\
(\mathrm{psi})\end{array}$ & $\begin{array}{c}\text { Modulus (E) } \\
(\mathrm{psi})\end{array}$ \\
\hline 1 & 0.067 & 0.966 & 0.0647 & 1,685 & 66,000 \\
\hline 2 & 0.067 & 0.922 & 0.0618 & 1,828 & 70,000 \\
\hline Average & - & - & - & $\mathbf{1 , 7 5 0}$ & $\mathbf{6 8 , 0 0 0}$ \\
\hline
\end{tabular}




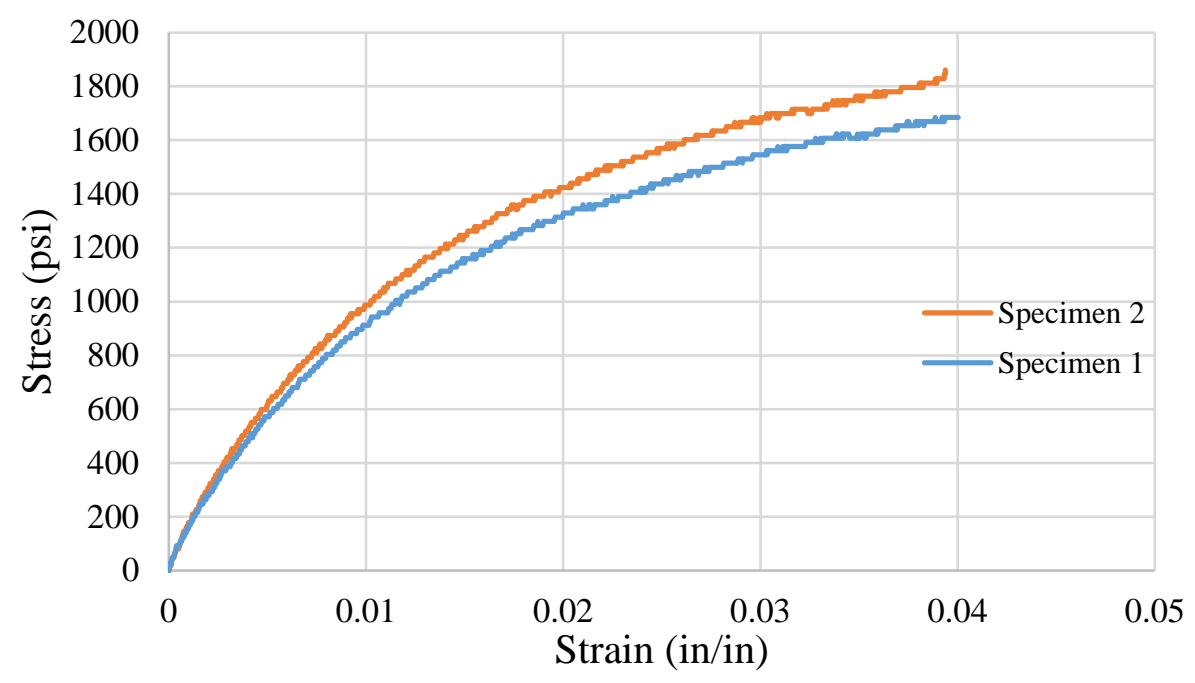

Figure 3. 16 Tensile stress vs. strain relationship for geoweb specimens

The average maximum stress $\left(\sigma_{\mathrm{ave}, \max }\right)$ is approximately $1,750 \mathrm{psi}$ with an average modulus of elasticity ( $\mathrm{E}_{\text {ave }}$ ) calculated to be $68 \mathrm{ksi}$ at $2 \%$ strain.

$\underline{\text { Summary from Product Data Sheets }}$

The manufacturer provided geo-polymer properties are summarized in Table 3.7 and Table 3.8 for the woven geotextile, geogrid, and geo-web/cells.

Table 3. 7 Woven fabric/ geogrid properties

\begin{tabular}{|l|c|c|c|c|c|}
\hline \multicolumn{1}{|c|}{$\begin{array}{c}\text { Woven Fabric } \\
\text { (WF)/Grid }\end{array}$} & $\begin{array}{c}\text { Material } \\
\text { Make-Up }\end{array}$ & $\begin{array}{c}\text { Tensile } \\
\text { Strength @ } \\
2 \% \text { Strain } \\
\text { (lbs/ft.) }\end{array}$ & $\begin{array}{c}\text { Elongation } \\
(\%)\end{array}$ & $\begin{array}{c}\text { Trapezoidal } \\
\text { Tear } \\
(\mathrm{lb})\end{array}$ & $\begin{array}{c}\text { CBR } \\
\text { Puncture } \\
\text { (lbs) }\end{array}$ \\
\hline $\begin{array}{l}\text { Separation Woven } \\
\text { Geotextile }\end{array}$ & Polypropylene & - & 15 & 75 & 700 \\
\hline $\begin{array}{l}\text { Reinforcement Woven } \\
\text { Geotextile }\end{array}$ & Polypropylene & 540 & 15 & $180 \times 140$ & 1400 \\
\hline Geogrid & Polypropylene & $280 \times 450$ & - & - & - \\
\hline
\end{tabular}


Table 3. 8 Geoweb properties

\begin{tabular}{|l|c|c|c|c|}
\hline $\begin{array}{c}\text { Geoweb } \\
\text { Configurations }\end{array}$ & Material Make-Up & $\begin{array}{c}\text { Depth } \\
\text { (in) }\end{array}$ & $\begin{array}{c}\text { Seam Peel } \\
\text { Strength (lbs.) }\end{array}$ & $\begin{array}{c}\text { Polymer Density } \\
\left(\mathrm{lb} / \mathrm{ft}^{3}\right)\end{array}$ \\
\hline Medium height & $\begin{array}{c}\text { High Density } \\
\text { Polyethylene (HDPE) }\end{array}$ & 6.0 & 480 & $58.4-60.2$ \\
\hline Large height & $\begin{array}{c}\text { High Density } \\
\text { Polyethylene (HDPE) }\end{array}$ & 8.0 & 640 & $58.4-60.2$ \\
\hline
\end{tabular}

\subsubsection{Recycled Tire (TDGC) Description and Properties}

Tire-derived geo-cylinders (TDGCs) that make-up Mechanical Concrete ${ }^{\circledR}$ were tested in tension and compression to determine their mechanical properties. The tire-derived geo-cylinders are obtained by stripping their inner remnants which result in just the outer wall or tread section (Bonasso 2013). Tire-derived geo-cylinders are obtained from discarded automobile tires provide confinement effects to base/sub base. The TDGC material typically consists of $34 \%$ natural rubber, $24 \%$ fillers (such as carbon black), 21\% steel, 11\% synthetic polymers, and 10\% curing compounds (U.S. Tire Manufacturers Assoc., 2018). Overall, the internal pressure of a tire-derived geo-cylinder is within 25 psi for light traffic tires and 50 psi for medium truck tires when exposed to AASHTO Truck Wheel Load (Bonasso, 2013). Overall, two different sized diameters and thickness of geo-cylinders were used for testing. The smaller geo-cylinders were approximately 16-18 inches in diameter with a 6-9 inch height. The tire-derived geo-cylinders were about 24-26 inches in diameter with a height of 8-9 inches (Figure 3.18).

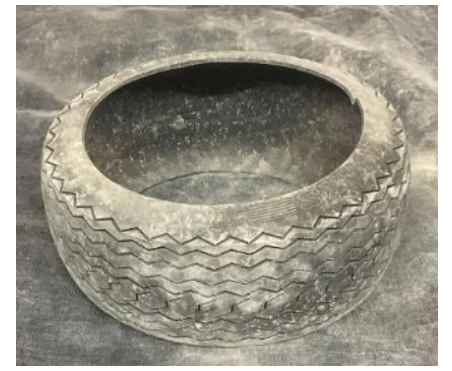

(a)

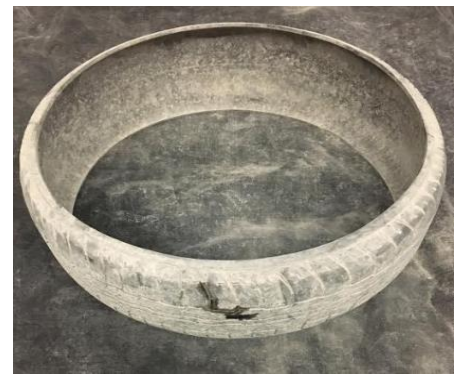

(b)

Figure 3. 17 Tire-derived geo-cylinders (TDGC) (a) small geo-cylinder ( $\sim 16$ " diameter), or TDGC-S (b) large geo-cylinder ( 24 " diameter), or TDGC 


\section{$\underline{\text { TDGC Material Properties }}$}

Tension and compression testing was performed on coupon test specimens obtained from steel reinforced thin-walled tire specimens. Two specimens were obtained for tension and three specimens for compression testing. Tensile stress, compressive stress, and the elastic modulus were obtained from the test specimens. The dimensions for the tested TDGC specimens are shown in Table 3.9.

Table 3.9 Summary of the coupon tension test specimens from a TDGC

\begin{tabular}{|c|c|c|c|}
\hline Specimen & Thickness & Width (in) & Area $\left(\mathrm{in}^{2}\right)$ \\
\hline 1 & 0.351 & 1.11 & 0.390 \\
\hline 2 & 0.341 & 1.152 & 0.393 \\
\hline
\end{tabular}

Figure 3.18 shows the initial cross section for a TDGC tensile test coupon. The steel reinforcement is noticeable in several layers within the tire wall. Initial material failure was noticed within the rubber compound of the coupon specimen (Figure 3.18).

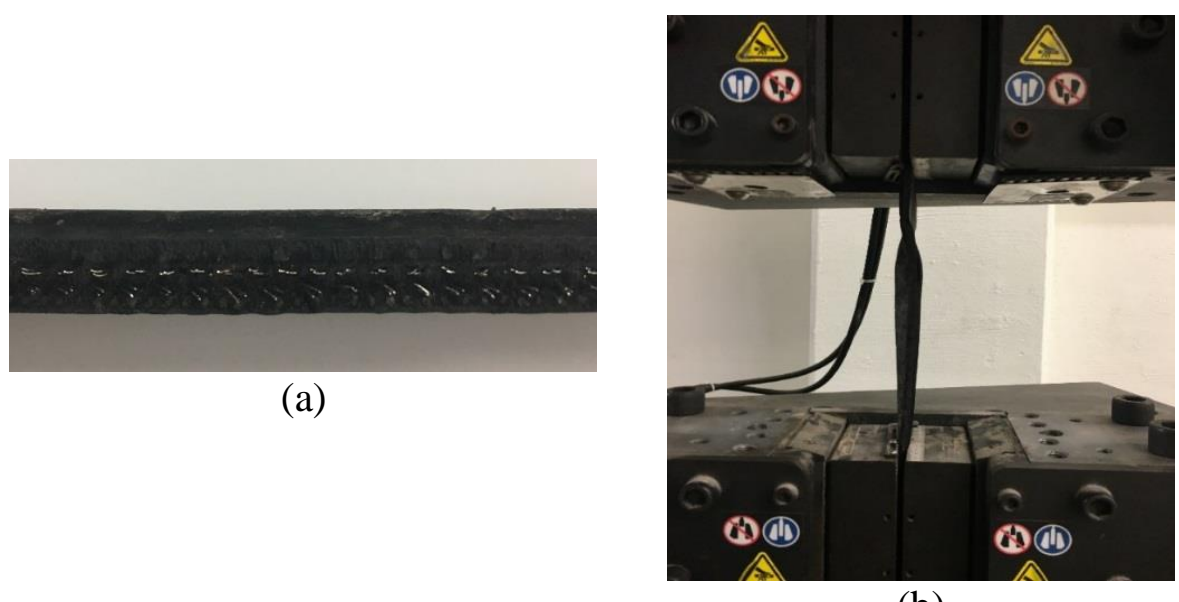

(b)

Figure 3. 18 Tensile testing the TDGC (a) TDGC cross section (b) TDGC specimen in tension

Final failure occurred as result of specimen stretching and twisting. It appears that once in tension, the rubber peeled away from the steel reinforcement causing a reduction in the load carrying capacity of the specimen resulting in failure as shown in Figure 3.20. Stress-strain relationship is plotted in Figure 3.19. 


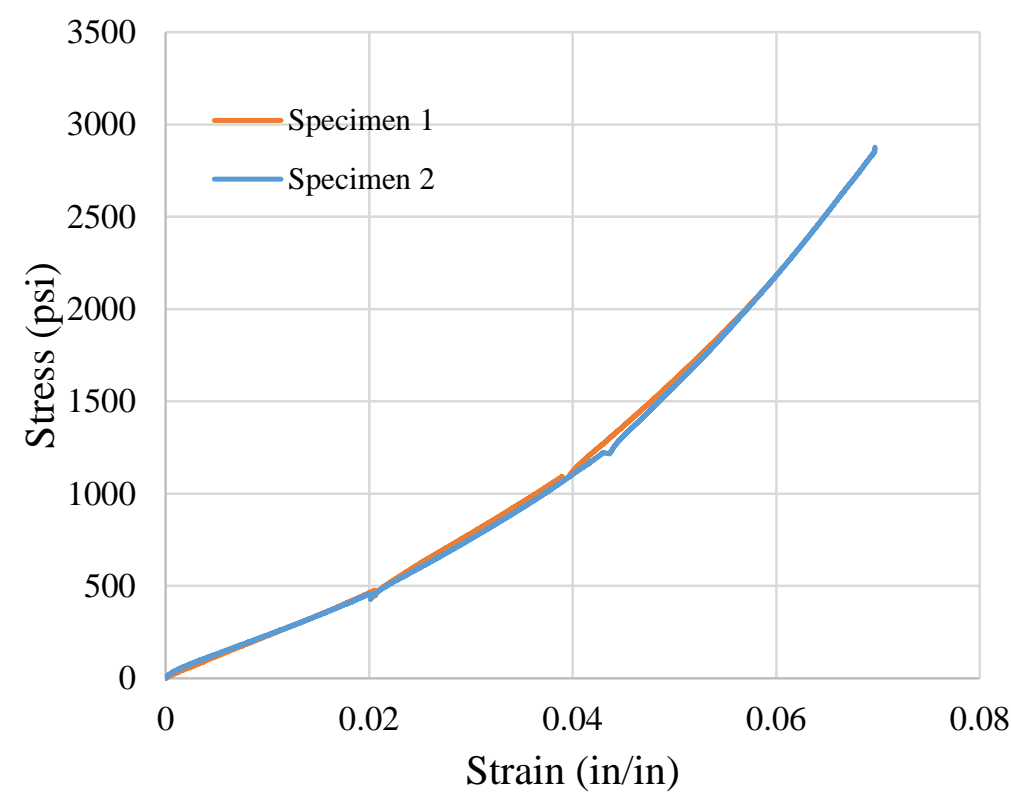

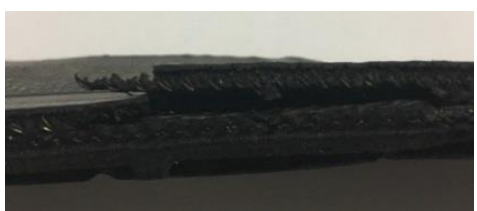

(b)

(a)

Figure 3. 19 Stress vs. strain relationship for tensile tested TDGC specimens

Compression testing was performed on compression specimens with the same (steel strand reinforcement) as the tensile specimens. Figure 3.20 shows the cross section of the compression specimen. Within the specimen, steel reinforement can be observed in three woven strands per reinforcement component. The test set-up and tested specimens are shown in Figure 3.21 and Figure 3.22.

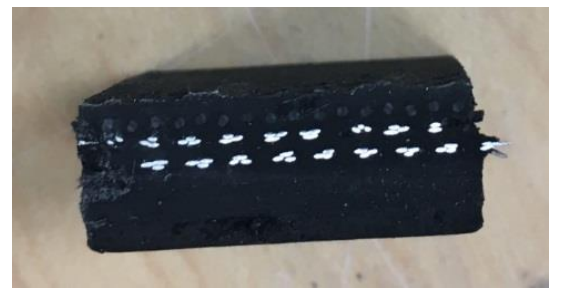

Figure 3. 20 TDGC specimen used for compression testing

Table 3.10 shows the dimensions for the tensile tested TDGC specimens. Same specimens were utilized to obtain their average density of the TDGC. 
Table 3. 10 Summary of geoweb compression tested specimens

\begin{tabular}{|c|c|c|c|c|c|c|c|}
\hline Specimen & $\begin{array}{c}\text { Length } \\
\text { (in) }\end{array}$ & $\begin{array}{c}\text { Width } \\
\text { (in) }\end{array}$ & $\begin{array}{c}\text { Area } \\
\left(\text { in }^{2}\right)\end{array}$ & $\begin{array}{c}\text { Thickness } \\
\text { (in) }\end{array}$ & $\begin{array}{c}\text { Mass } \\
(\mathrm{lb})\end{array}$ & $\begin{array}{c}\text { Volume } \\
\left(\text { (n }^{3}\right)\end{array}$ & $\begin{array}{c}\text { Density } \\
\left(\text { lb/in }^{3}\right)\end{array}$ \\
\hline 1 & 1.015 & 0.910 & 0.924 & 0.386 & 0.0179 & 0.357 & 0.050 \\
\hline 2 & 0.960 & 0.905 & 0.869 & 0.380 & 0.0172 & 0.330 & 0.052 \\
\hline 3 & 1.017 & 0.892 & 0.907 & 0.382 & 0.0184 & 0.347 & 0.053 \\
\hline \multicolumn{70}{|c}{} & $\begin{array}{c}\text { Average } \\
\text { Density }\end{array}$ & $\mathbf{0 . 0 5 2}$ \\
\hline
\end{tabular}

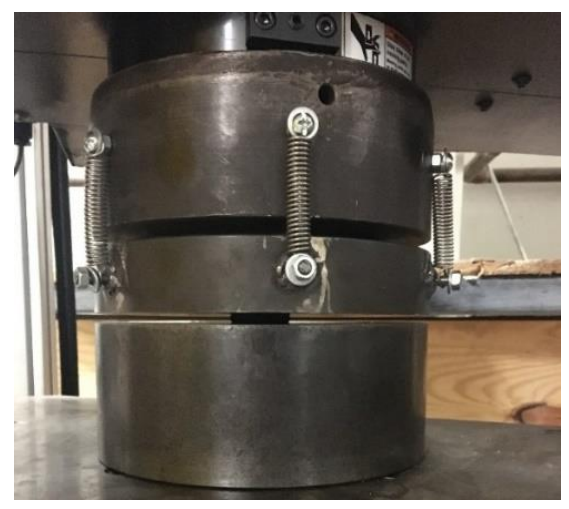

Figure 3. 21 Compression testing of the TDGC specimen

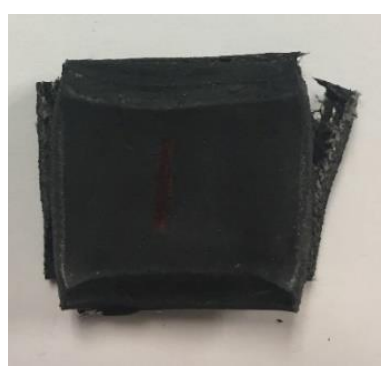

(a)

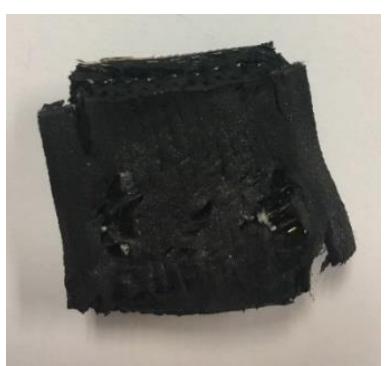

(b)

Figure 3. 22 Failed compression specimen (a) top view of the failed compression tire specimen (b) back view of the failed compression specimen

Failure occurred in the specimen due to the separation of rubber from the steel reinforcement as shown in Figure 3.22. Compression stress vs. strain plot is shown in Figure 3.23. 
The plot shows a strong similarity between all tested specimens. The data shows material relaxations at approximately $8 \mathrm{ksi}$ and $35 \mathrm{ksi}$.

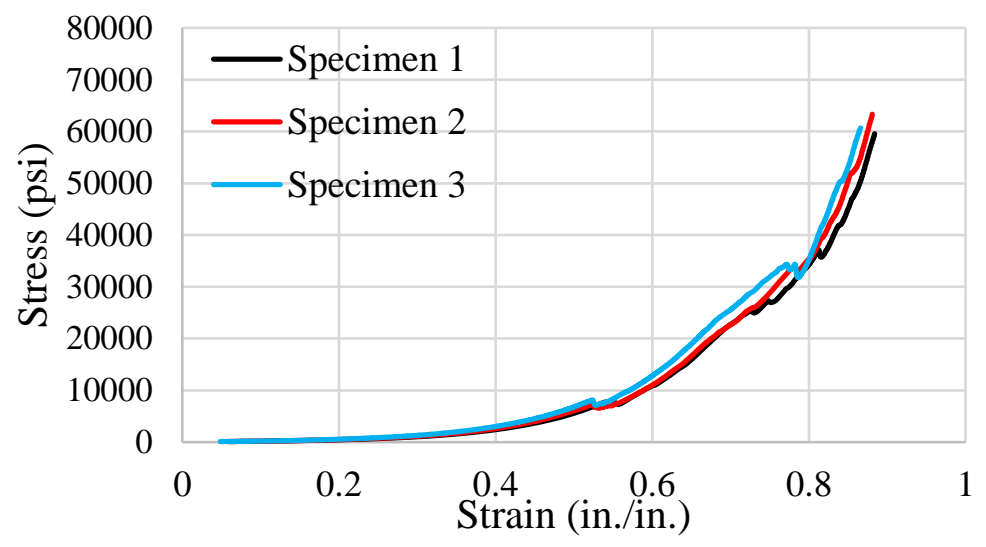

Figure 3. 23 Compression stress vs. strain graph

The summary of tension and compression tests for steel reinforced tire specimens are shown in Table 3.11.

Table 3. 11 Physical and mechanical properties of TDGC specimens

\begin{tabular}{|c|c|}
\hline Average Maximum Compressive Stress (ksi) & 60.0 \\
\hline Maximum Compressive Stress (ksi) & 63.0 \\
\hline Average Maximum Tensile Stress (ksi) & 2.8 \\
\hline Maximum Tensile Stress (ksi) & 2.8 \\
\hline Average Maximum Modulus of Elasticity in Tension (ksi) & 40.0 \\
\hline Average Maximum Modulus of Elasticity in Compression (ksi) & 70.0 \\
\hline Density (lb/in ${ }^{3}$ ) & 0.052 \\
\hline
\end{tabular}

\subsubsection{AASHTO \#57 Coarse Aggregate}

As per the West Virginia Division of Highways specification in 2013, AASHTO \#57 aggregate was used in each bin for filling different types of reinforcement such as TDGCs and geowebs used for strengthening of the base/sub base in test bins. Aggregate was placed in the bin at a height of about 2 " above the top of the base/sub base reinforcement materials.

\subsection{Laboratory Test Procedures}

The test set-up and procedure used for lab testing was aimed at simulating the field construction of pavement and applying loads on the pavement. The load plate rested above the aggregate filled TDGCs and geo-web/cells during cyclic testing. Both (large and small bin) 
construction and infill materials were similar. Large bin testing consisted of lower degree of compaction for a SM-soil subgrade with higher saturation conditions; whereas the small bin testing consisted of moderately moist SM-soil with an adequate degree of compaction, as determined from the nuclear gauge testing described before. The compacted subgrade was overlaid with a separation woven geotextile fabric. The reinforcement specimens were then placed on top of the separation woven geotextile fabric and filled over with AASHTO \#57 aggregate as shown in Figure 3.24. Static and fatigue testing of different reinforcement configurations consisting of TDGC and geo-web specimens were conducted under static and fatigue loads. Similar test se-up has also been used in other studies (Khalaj et al, 2014).

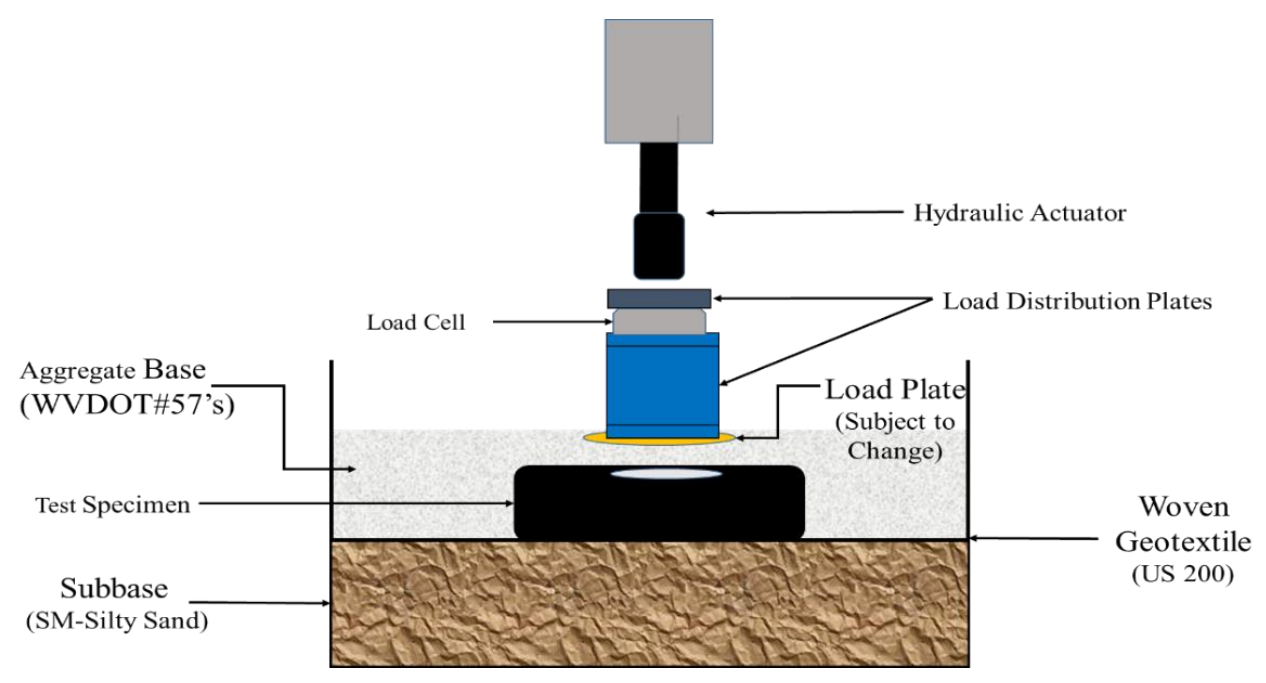

Figure 3. 24 Schematic of test set-up for large and small bin testing with tire-derived geocylinder (TDGC)

\section{Large Test Bin Loading Procedure}

The TDGC specimens in the large bin were subjected to static loading with respect to two different plate sizes, 15 inch and 24 inch. Three tire-derived geo-cylinder (TDGC) configurations were examined. Loads were applied with an MTS Hydraulic Actuator, and displacement and load were measured by using a Linear Variable Differential Transducer (LVDT) and 50 kip load cell. Data was recorded via Strain Smart 8000 system. Plates were loaded gradually as displacement was incrementally recorded for limits of $0.025 \mathrm{inch}, 0.05 \mathrm{inch}, 0.075 \mathrm{inch}, 0.1 \mathrm{inch}$, and 0.125 inch. 


\section{Small Test Bin Loading Procedure}

\section{$\underline{\text { Static Testing Procedure for Small Test Bin }}$}

Static testing was conducted in the small bin with respect to various TDGC and geoweb configurations. Similar to the large testing bin, no pre-compaction of aggregate was done. The displacement limit of 0.15 inch was used for each of the tests. Three tests were conducted per loading plate size per specimen. The third cycle was used for analysis purposes. Loading plates (12" and 15") were utilized in the same manner as the large bin. Load versus displacement data was recorded utilizing the load cell, LVDT, and data acquisition systems.

\section{Fatigue Testing Procedure for Small Test Bin}

Fatigue testing was conducted following static tests. Only a 12" diameter plate was used for the fatigue loading. Sinusoidal loadings were used for the fatigue tests (Mollenhaurer, 2009). A sinusoidal load frequency of 2 Hertz (Hz.) was applied on each test specimen. This test frequency corresponded to conclusions from previous research by Gillespie and Sayers (1981). They concluded that resonance of basic automobile and commercial vehicles can span from 1 to $3 \mathrm{~Hz}$. They also observed the on-road resonance on the tires was in the vicinity of $3 \mathrm{~Hz}$ which reasons to use a comparative frequency. By utilizing $2 \mathrm{~Hz}$, this research observed the fatigue loading effects of basic automobile tires and commercial vehicles on a roadway section. For our research, two separate loading conditions, a low load range (0.5 to $1.0 \mathrm{kip})$ and a high load range (1.0 to 4.0 kip), were used during testing. All fatigue test specimens were loaded up to 1 million cycles or beyond. Higher loads were conducted setting a limitation of 0.75 inches. If the displacement limit was reached during testing prior to 1 million or higher cycle completion, testing was stopped, and the data was noted. Following the 1 million cycle testing, the 8" geoweb and TDGC were tested up to 3 million fatigue cycles. 
A variety of plate sizes were used for conducting static and fatigue testing. The plate sizes correspond to standard tire sizes or the footprint of a dual-wheeled AASHTO truck. The plates are shown in Figure 3.25.

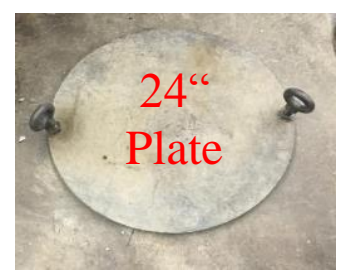

(a)

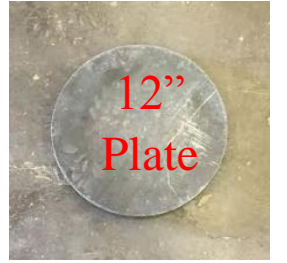

(c)

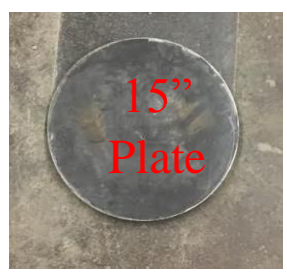

(b)

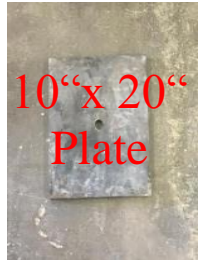

(d)

Figure 3. 25 Plate sizes (a) 24" (b) 15" (c) 12" (d) 10" x 20"

Different plate sizes used in this study reflect the pavement area loaded by a tire during its travel. According to literature (Yap, 1989), the given load area for a dually truck is $114 \mathrm{in}^{2}$ which corresponds to the surface area of a 12 " circular plate. The 15" and 24" plates were used to observe stresses and moduli responses of the base/sub base with respect to the dual tire loads. The 10"x20" plate was used to mimic the imprint of dual wheels (Figure 3.26).

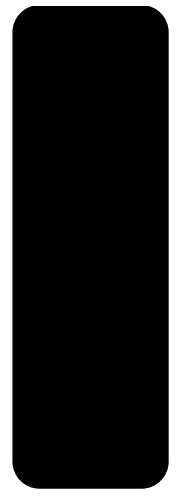

(a)

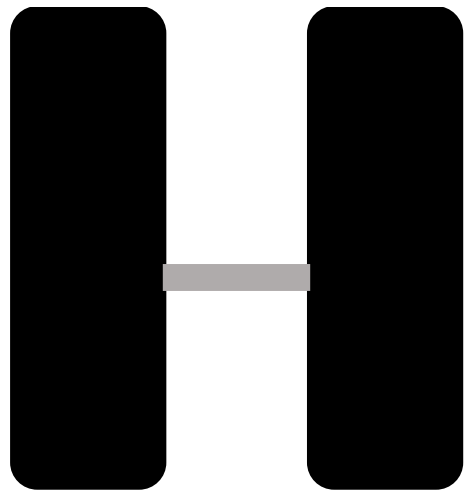

(b)

Figure 3. 26 Load area for vehicular tires (a) plan, or top view of a large tire (b) plan, or top view of a dually tire 


\subsection{Summary of Materials and Procedures}

This chapter aimed at providing an understanding of the materials and their properties used in this research including procedures used for laboratory testing in the large roadway section (large bin) and small roadway section (small bin) (Figure 3.27). The static and fatigue testing procedures, frequency ranges, and measurements of displacements are also described. Test results and analysis of test data are provided in Chapter 4.

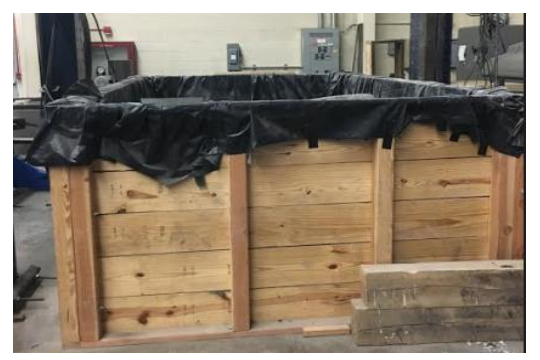

(a)

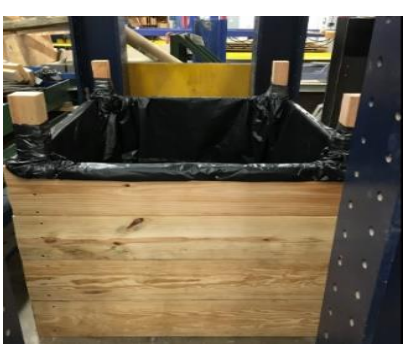

(b)

Figure 3. 27 Representative pavement (roadway) section set-up (a) large bin, 7' x 12'

(b) small bin, 4' x 6' 


\section{TEST RESULTS AND ANALYSIS}

This chapter provides the details on test static and fatigue data and analyses for different base/sub base strengthening configurations described in Chapter 3. Data from both the large and small test bin with different tire-derived geo-cylinders (TDGC) and geo-web configurations are presented and discussed.

\subsection{Large Testing Bin Data}

Large bin testing was performed on subgrade with a low degree of compaction by statically loading the 15 " and 24 " plates to displacement limits of 0.025 " increments. The TDGCs were laid adjacent to one another on top of the compacted subgrade and separation fabric, and filled with AASHTO \#57 aggregate to create a base/sub base layer also known as Mechanical Concrete ${ }^{\circledR}$. Three TDGC configurations were evaluated and compared (Figure 4.1).

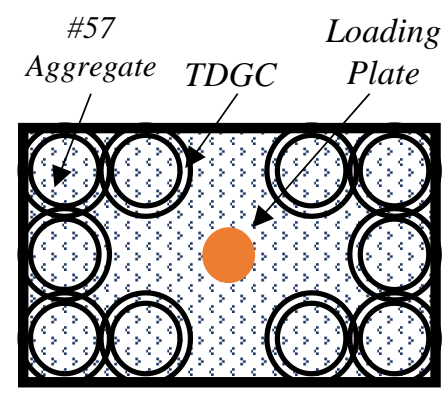

(configuration-a)

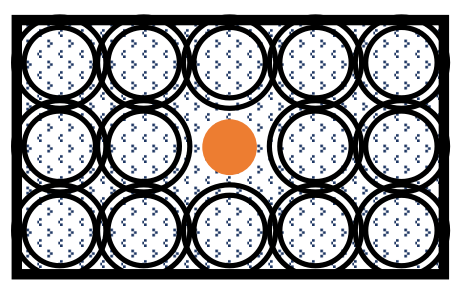

(configuration-b)

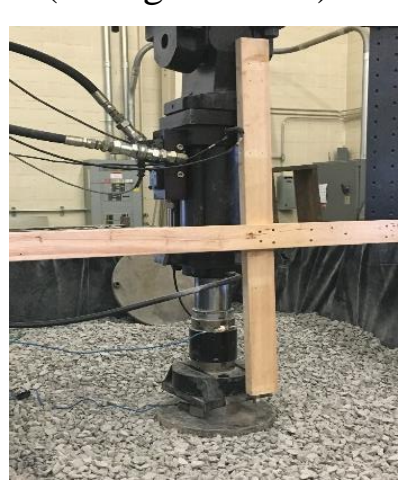

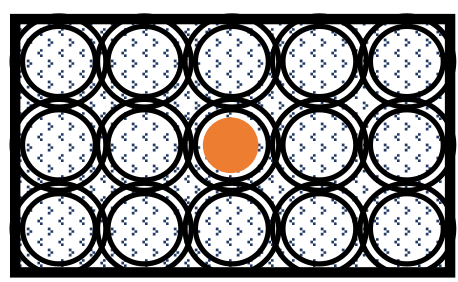

(configuration-c)

(d)

Figure 4. 1 TDGC configurations for large bin testing

(a) five central TDGCS removed (b) one central TDGC removed

(c) all TDGCs present (d) large bin testing

Maximum static load application corresponded to a displacement of 0.125 inch. Tables 4.1 and 4.2 provide the overall base/sub base moduli at different displacement (disp.) levels up to 
0.125 inch. Performance between Configurations A to $\mathrm{C}$ (Table 4.1 and 4.2) for different incremental displacements corresponding to 15 " and 24 " diameter plates are included.

Table 4. 1 Base/sub base modulus of three configurations of pavement representative section (large bin) with the use of 15 " diameter loading plate and their percent increase

\begin{tabular}{|c|c|c|c|c|}
\hline \multirow{2}{*}{$\begin{array}{c}\text { Disp. } \\
\text { level } \\
\text { (in) }\end{array}$} & \multicolumn{3}{|c|}{ Base/sub base modulus (psi/in) } & $\begin{array}{c}\text { Percentage increase of } \\
\text { configuration-c over } \\
\text { configuration-a } \\
(\%)\end{array}$ \\
\cline { 2 - 4 } & $\begin{array}{c}\text { Configuration } \\
\text { A }\end{array}$ & $\begin{array}{c}\text { Configuration } \\
\text { B }\end{array}$ & $\begin{array}{c}\text { Configuration } \\
\text { C }\end{array}$ & 62.9 \\
\hline 0.025 & 341.79 & 353.11 & 556.83 & 88.1 \\
\hline 0.05 & 314.63 & 389.33 & 591.91 & 101.6 \\
\hline 0.075 & 287.47 & 331.99 & 579.47 & 122.4 \\
\hline 0.10 & 250.12 & 280.68 & 556.26 & 113.9 \\
\hline 0.125 & 234.96 & 244.46 & 502.51 & \\
\hline
\end{tabular}

Table 4. 2 Base/sub base modulus of three configurations of pavement representative section (large bin) with the use of 24" diameter loading plate and their percentage increase

\begin{tabular}{|c|c|c|c|c|}
\hline \multirow{2}{*}{$\begin{array}{c}\text { Disp. } \\
\text { level } \\
\text { (in) }\end{array}$} & \multicolumn{3}{|c|}{ Base/sub base modulus (psi/in) } & $\begin{array}{c}\text { Percentage increase due } \\
\text { to configuration-c over } \\
\text { configuration-a } \\
(\%)\end{array}$ \\
\cline { 2 - 4 } & $\begin{array}{c}\text { Configuration } \\
\text { A }\end{array}$ & $\begin{array}{c}\text { Configuration } \\
\text { B }\end{array}$ & $\begin{array}{c}\text { Configuration } \\
\text { C }\end{array}$ & 15.3 \\
\hline 0.025 & 179.49 & 189.22 & 206.90 & 27.8 \\
\hline 0.05 & 213.09 & 241.38 & 272.33 & 20.1 \\
\hline 0.075 & 223.11 & 254.35 & 267.91 & 16.8 \\
\hline 0.10 & 222.15 & 254.65 & 259.51 & 18.3 \\
\hline 0.125 & 213.97 & 233.96 & 253.06 & \\
\hline
\end{tabular}

Within the displacement limit of 0.125 inch, increases of $113.9 \%$ and $18.3 \%$ in base/sub base moduli with respect to two different loading plate sizes were observed. Figures 4.2 and 4.3 show the base/sub base moduli for the three configurations at different displacement levels. 


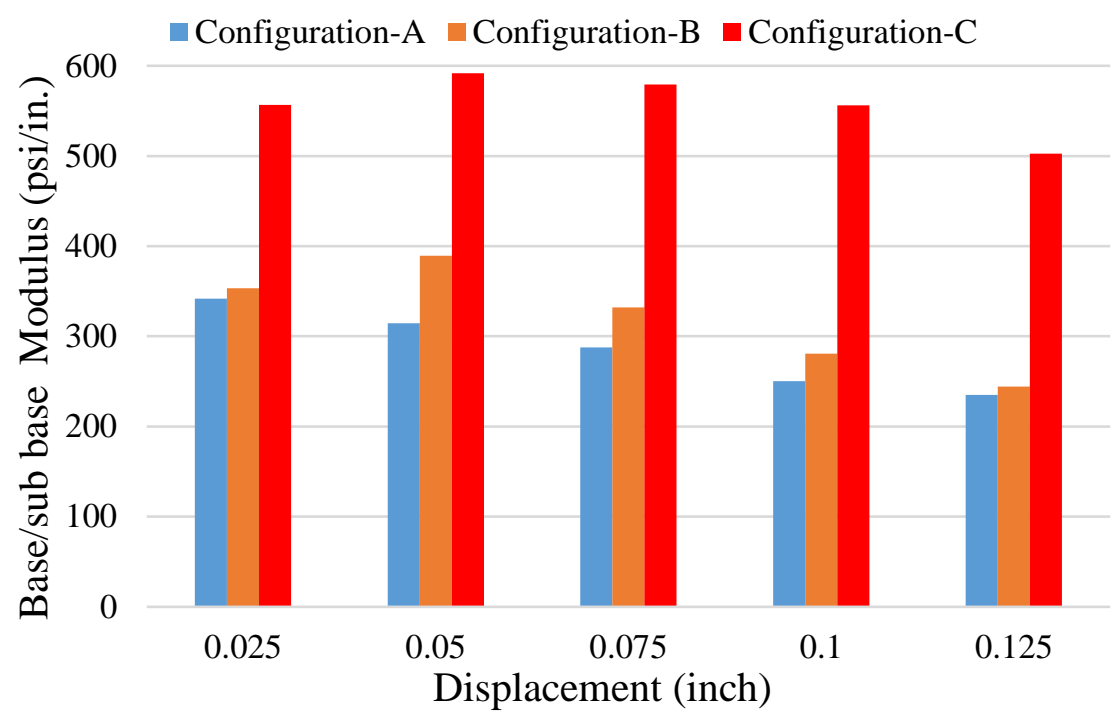

Figure 4. 2 Base/sub base moduli for 15 " loading plate (large test bin)

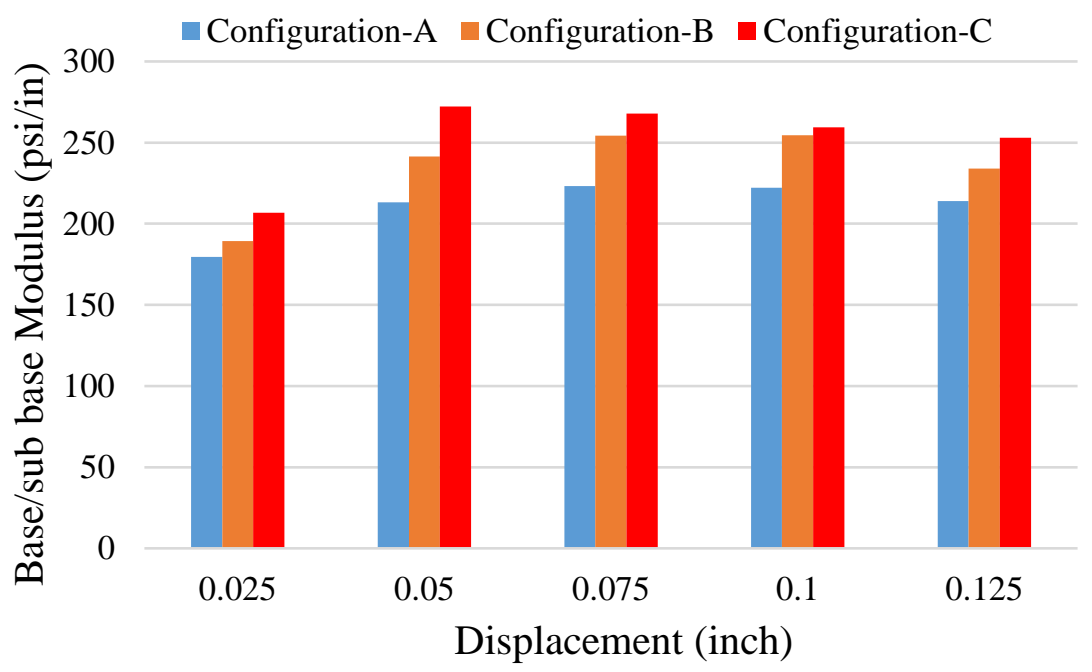

Figure 4. 3 Base/sub base moduli for 24" loading plate (large test bin)

\subsection{Small Testing Bin Data}

To further examine the performance of TDGCs and the geo-polymers, tests were conducted on representative pavement sections in a smaller bin. This bin was used for static testing and fatigue testing up to 3 million cycles. Following the 3 million cycle cases, post-static testing was performed. In the small bin, static loading was also conducted on asphalt and concrete slab sections placed on top of the aggregate filled TDGCs and geowebs. All TDGC and geoweb specimens were filled with AASHTO \#57 aggregate and tested using either a 15 " or 12 " plate. Only 12 " diameter 
plate was utilized for fatigue testing. Various configurations utilized throughout the testing in the small bin are shown in Figure 4.4.

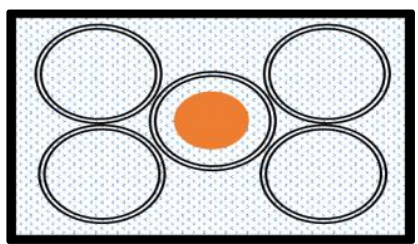

(a) 5 TDGC-S

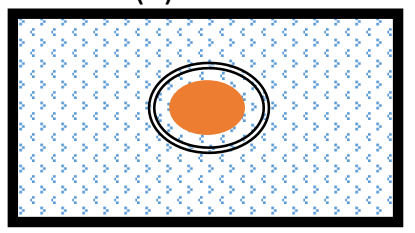

(d) TDGC-S

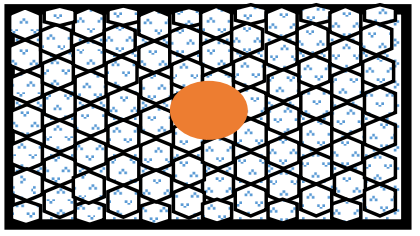

(g) geoweb (6" and $\left.8^{\prime \prime}\right)$

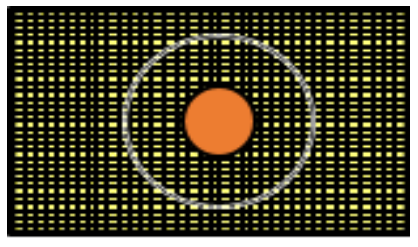

(j) woven geotextilegeogrid-TDGC

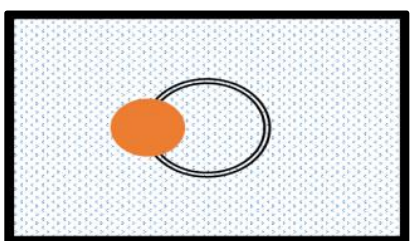

(b) offset

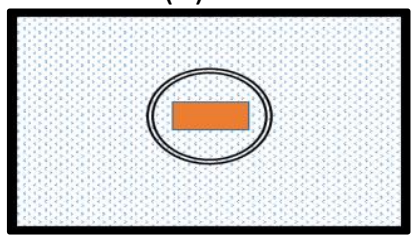

(e) TDGC-S footprint

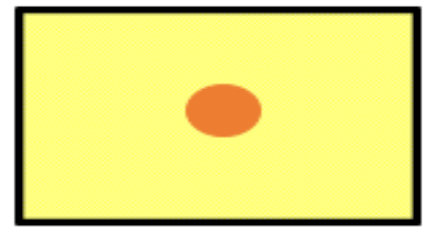

(h) woven geotextile

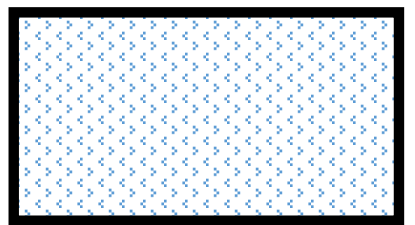

(k) base condition

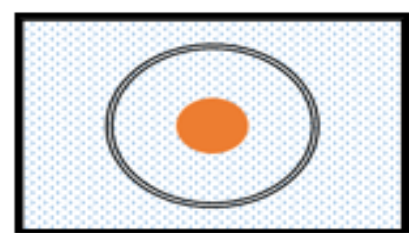

(c) TDGC

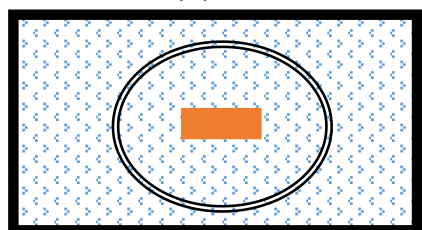

(f) TDGC footprint

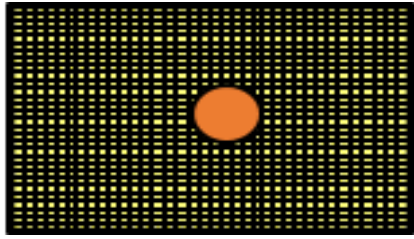

(i) woven geotextile and with geogrid

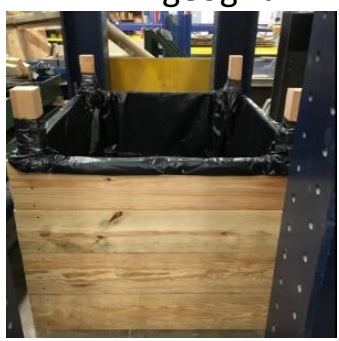

(I) small test bin $\left(4^{\prime} \times 6^{\prime}\right)$

Figure 4. 4 Testing configurations for static testing in the small bin (a) five small TDGC-S or 5 TDGC-S (b) offset (c) TDGC (d) small TDGC or TDGC-S (e) TDGC-S footprint using 10"x20" plate (f) TDGC footprint using 10"x20" plate (g) geoweb - 6 inch and 8 inch thickness (h) woven geotextile (i) woven geotextile with geogrid (j) woven geotextile-geogrid-TDGC (k) base condition with no TDGC (1) small test bin

\subsubsection{Static Testing (Small Bin)}

Static testing in the small bin testing was previously discussed in the Section 3.2. The base/sub base moduli pertaining to each configuration was determined and compared. Comparison of base/sub base moduli between base (control specimen) and different configurations of mechanical concrete using TDGCs are provided in Table 4.3. The TDGC performed better than TDGC-S configurations, and therefore was used to compare against the base values. Displacement (disp.) limits of 0.125 inch used in the large bin testing were increased to 0.150 inch in the small 
bin testing for allowing the moduli evaluation over an increased displacement range. With respect to base values, the base/sub base reinforced with the TDGC showed an increase in the base/sub base modulus by $34-35 \%$ (Figure 4.5). The TDGC (tire derived geo-cylinders) with the presence of steel reinforcement are expected to provide better confinement effects as compared to the TDGC-S (small tire derived geo-cylinders) that are not steel reinforced along their tread area.

Table 4. 3 TDGC static test summary in the small (4'x6') bin

\begin{tabular}{|c|c|c|c|c|c|c|c|}
\hline $\begin{array}{c}\text { Disp. } \\
\text { limit }\end{array}$ & $\begin{array}{c}\text { Plate } \\
\text { diameter }\end{array}$ & \multicolumn{5}{|c|}{$\begin{array}{c}\text { Base/sub base moduli } \\
\text { (psi/in) }\end{array}$} & $\begin{array}{c}\text { Percent difference } \\
\text { from configuration } \\
\text { TDGC to Base value }\end{array}$ \\
\hline (in.) & (in.) & Base & TDGC-S & $\begin{array}{c}5 \\
\text { TDGC-S }\end{array}$ & Offset & TDGC & $(\%)$ \\
\hline 0.150 & 12 & 200 & 158 & 171 & 153 & 267 & 34 \\
\cline { 2 - 8 } & 15 & 196 & 148 & 162 & 200 & 265 & 35 \\
\hline
\end{tabular}

Note: 1 inch $=25.4 \mathrm{~mm} ; 1 \mathrm{psi}=0.00689 \mathrm{MPa}$

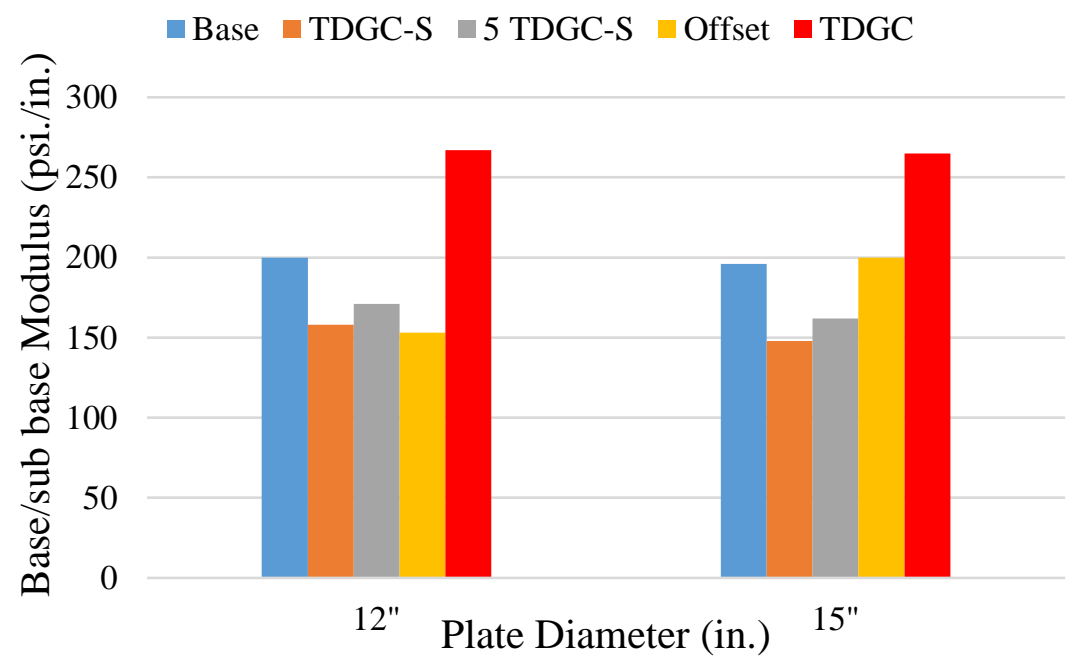

Figure 4. 5 Base/sub base moduli with respect to tire-derived geo-cylinder (Mechanical Concrete $\left.{ }^{\circledR}\right)$ configurations and plate sizes.

Static tests were also conducted with a rectangular 10 " $\times 20$ " steel plate to simulate the AASHTO truck dual-tire imprint and the corresponding base/sub base moduli were determined (Figure 4.6). The base/sub base moduli for TDGCs with both rectangular and circular plates were nearly similar (267 psi/ in. vs. 257 psi. /in.) and within $4 \%$ of each other. The slight difference is likely attributed to the increase of area in the 10 "x 20 " rectangular plate. In the case of testing the TDGC-S with a 12 inch plate, lower performance was noted in the same manner as previous tests 
which confirms that the TDGC-S performance is relatively lower in comparison to a TDGC reinforced along the tread area.

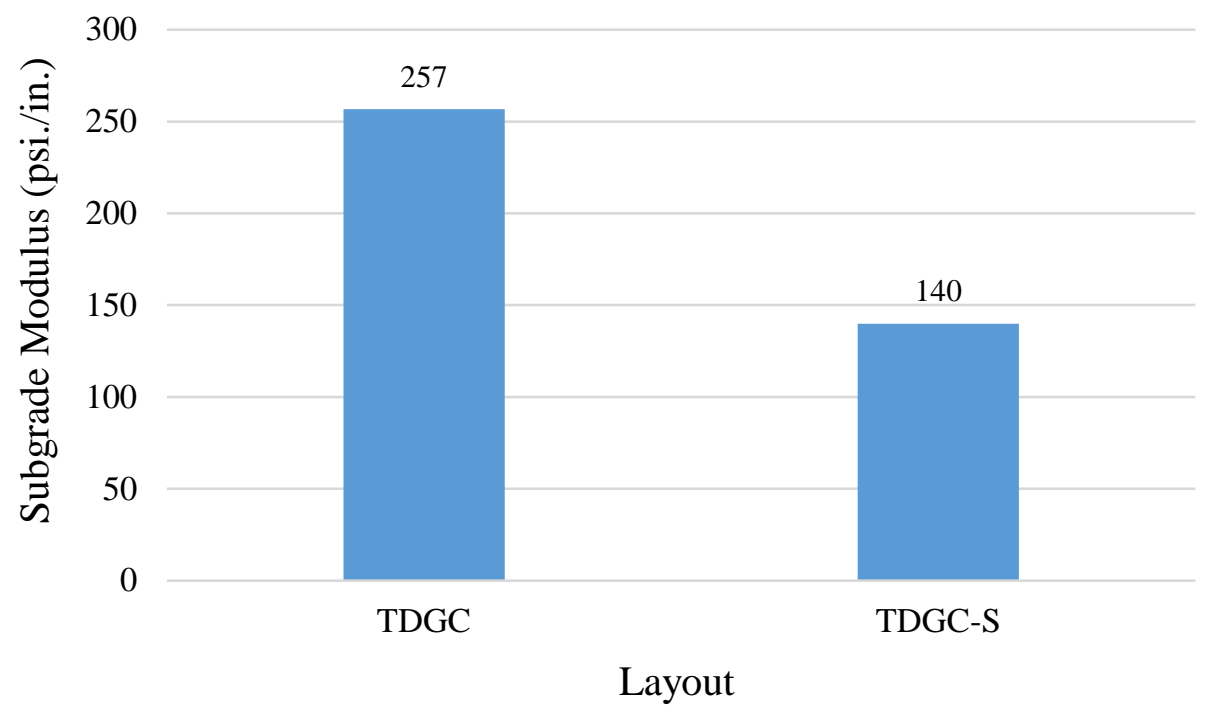

Figure 4. 6 10"x 20" footprint base/sub base moduli result

Table 4.4 and Figure 4.7 show the comparison of TDGC with the two geoweb sizes of 6" and 8". Use of both the TDGC and the geowebs improved the base/sub base moduli as compared to the base (control) specimen without any reinforcement. Data collected from the small bin tests helped in deciding the configurations to be used for further fatigue testing. The test results show similar performance between TDGC and the 8 inch geoweb with their base/sub base moduli being within $10 \%$ of each other (Table 4.4). As compared to 8 inch geoweb, the TDGC showed about $7 \%$ better performance under 12 inch diameter plate loading and nearly identical response under 15 inch plate testing (Table 4.4). Both TDGC and geowebs provided confinement effects to enhance the performance of base/sub base. The smaller honey-comb shaped sections in the geoweb consist of multiple walls that provide local confinement effects, whereas the steel belt reinforced TDGC provides both vertical stiffness as well has confinement effects. 
Table 4. 4 TDGC and geoweb (6" and 8") static testing summary

\begin{tabular}{|c|c|c|c|c|c|c|}
\hline $\begin{array}{c}\text { Disp. } \\
\text { limit }\end{array}$ & $\begin{array}{c}\text { Plate } \\
\text { diameter }\end{array}$ & \multicolumn{4}{|c|}{$\begin{array}{c}\text { Base/sub base moduli } \\
\text { (psi/in) }\end{array}$} & $\begin{array}{c}\text { Percent difference } \\
\text { from configuration TDGC } \\
\text { to 8“geoweb value }\end{array}$ \\
\hline (in.) & (in.) & Base & 6 " Geoweb & 8 " Geoweb & TDGC & $(\%)$ \\
\hline 0.150 & 12 & 200 & 242 & 250 & 267 & 7 \\
\cline { 2 - 7 } & 15 & 196 & 240 & 262 & 265 & 1.15 \\
\hline
\end{tabular}

Note 1: 1 inch $=25.4 \mathrm{~mm} ; 1 \mathrm{psi}=0.00689 \mathrm{MPa}$

Note 2: Base case refers to the test with no TDGC or geoweb in the base/sub base

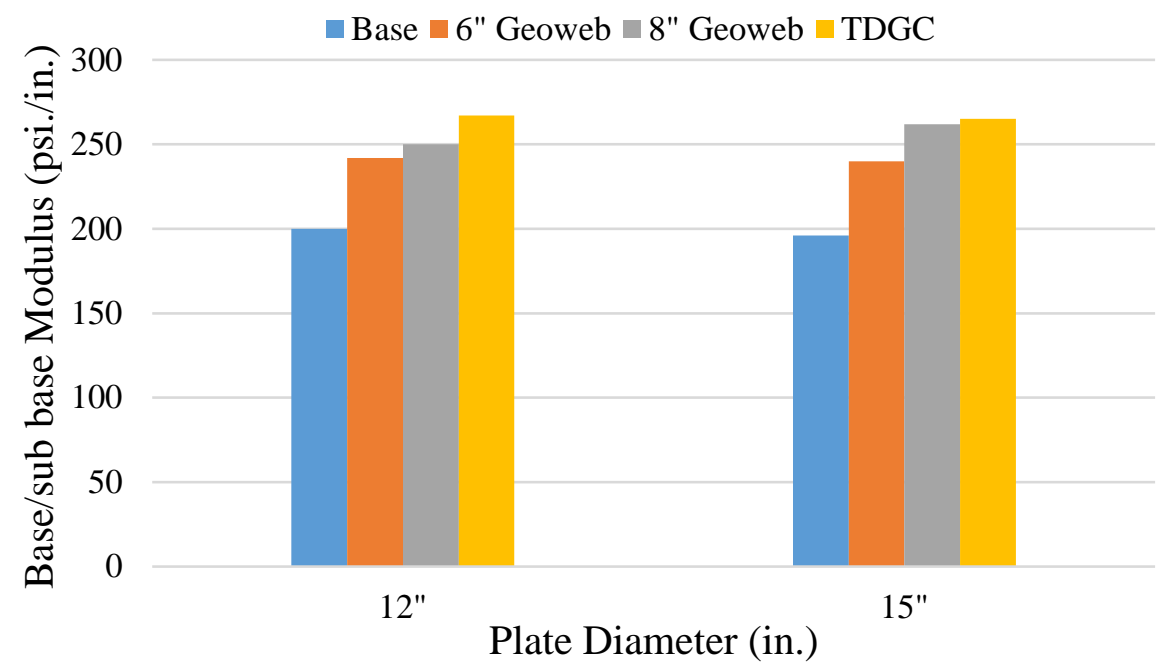

Figure 4. 7 Comparison of base/sub base moduli of TDGCs and geowebs

\subsubsection{Fatigue Test (Small Bin)}

\subsubsection{Low Load Range Case of 0.5-1.0 kip (1 million cycles)}

Results of fatigue loading tests are provided in Table 4.5 with respect to 1 million fatigue cycles. Base/sub base with TDGC showed 0.043" displacement after 1 million cycles of fatigue loading and contributed to a $67.4 \%$ increase in base/sub base modulus as compared to the base case. The 8 inch geoweb also provided a close performance to the TDGC with a displacement of 0.055 " and a $58 \%$ increase in the performance in the base/sub base modulus when compared to the Base case. 
Table 4. 5 Displacement at 1,000,000 cycles for specimens exposed to the lower load case

\begin{tabular}{|c|c|c|c|c|c|c|}
\hline $\begin{array}{c}\text { Low Load } \\
\text { Case } \\
\text { (kip) }\end{array}$ & $\begin{array}{c}\text { Plate } \\
\text { Diameter }\end{array}$ & Base & $\begin{array}{c}6 \text { inch } \\
\text { Geoweb }\end{array}$ & $\begin{array}{c}8 \text { inch } \\
\text { Geoweb }\end{array}$ & TDGC & $\begin{array}{c}\text { Percent difference } \\
\text { from } \\
\text { configuration } \\
\text { Base to TDGC } \\
\text { value }\end{array}$ \\
\hline 0.5 to 1.0 & 12 inch & 0.132 & 0.073 & 0.055 & 0.043 & $67.4 \%$ \\
\hline
\end{tabular}

Note: 1 inch $=25.4 \mathrm{~mm} ; 1 \mathrm{psi}=0.00689 \mathrm{MPa}$

Both TDGC and 8 inch geoweb help provide confinement effects and reduce the effects of punching shear. Cell walls of the geoweb and the circumferential steel reinforced tire tread of the TDGC help in providing the resistance against buckling and contribute to the spreading of the applied loads to a larger area. In cellular confinement systems, vertical loadings on the confined infill results in high lateral stress and corresponding resistance by individual cell walls. Wheel loads can cause shear punching in weaker subgrades. Confinement systems, such as Mechanical Concrete ${ }^{\circledR}$, provide considerable lateral resistance in addition to reduced local settlements (Kief, 2008). Figure 4.8 shows displacement (settlement) values with up to 1 million load cycles for pavement representative sections with and without the presence of mechanical concrete. Most of the settlement occurred within the first 10,000 to 100,000 cycles for each test configuration. Plotted trends reveal a significant decrease in displacement rate for the 0.5-1.0 kip load range in TDGC reinforced aggregate base sections

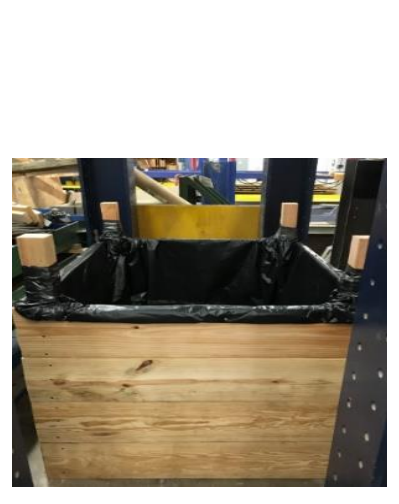

(a)

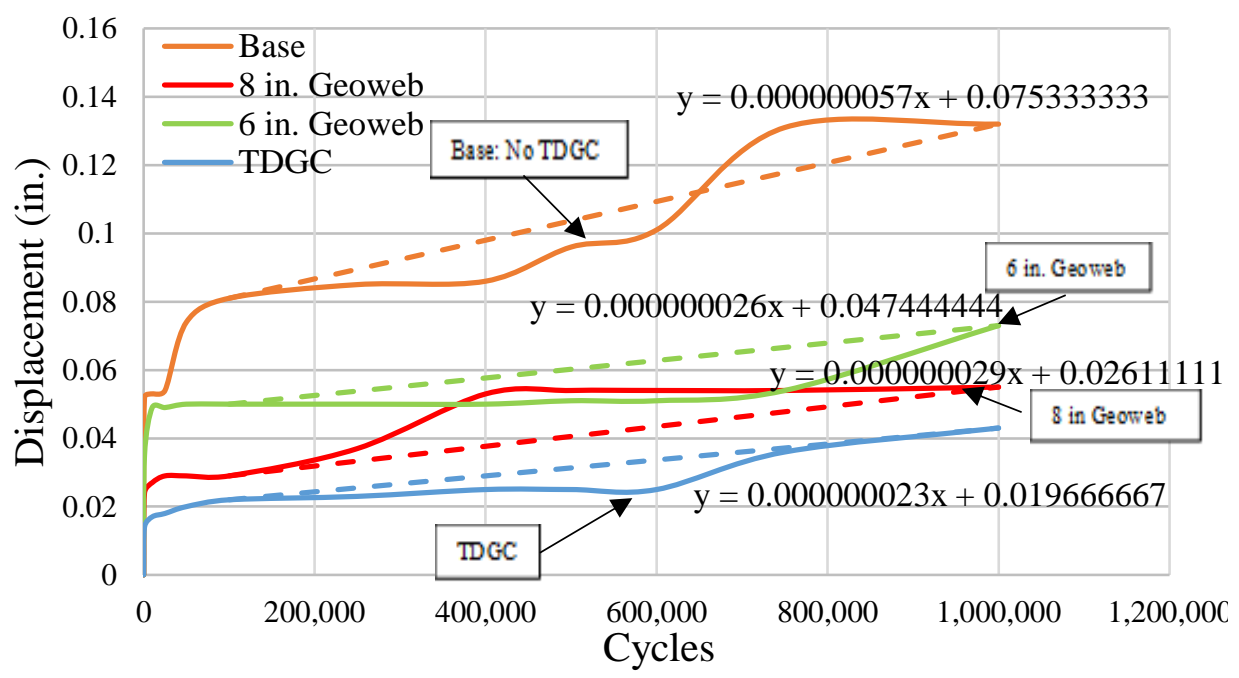

(b)

Figure 4. 8 (a) Small (4'x6') test bin fatigue tests (b) displacements for pavement section with and without mechanical concrete subjected to the lower fatigue load range (0.5-1.0 kip). 
Slopes of each material used for strengthening/reinforcing the base/subbase (Fig. 4.8) represent the displacement rate under the lower range fatigue loading of 0.5 to $1.0 \mathrm{kip}$ at $2 \mathrm{~Hz}$. The greatest rate of displacement occurred in the base configuration. The 6 inch geoweb and 8 inch geoweb showed somewhat similar slopes, except that the initial displacements were higher in the 6 inch geoweb. TDGC experienced the least amount of displacement rate change and had a lower projected rate of displacement beyond 1 million cycles as compared to all other materials. For fatigue loading with a lower load range of 0.5-1.0 kip, the settlements in non-reinforced base (control) sections were about 2.5 times higher than those with Mechanical Concrete ${ }^{\circledR}$ $(0.000000057 \mathrm{x}$ vs. $0.000000023 \mathrm{x})$.

\subsubsection{High Load Range Case of 1.0-4.0 kip (1 million cycles)}

Reinforced base/sub base specimens were subjected to loads of 1.0 to 4.0 kips at $2 \mathrm{~Hz}$. Woven geotextile with the ability to reinforce and stabilize the base/sub base and the bi-directional woven-geogrid combination were placed on top of the separator fabric as an additional test parameter. The base case is shown in Figure 4.9 as it quickly reached a displacement of 0.75 inch. Table 4.6 shows the final displacement data after 1,000,000 cycles of high load range (1.0-4.0 kip) fatigue loading. The data reflects that by combining the geogrid and woven geotextile, base/sub base performance is increased with respect to the woven geotextile used by itself. The composite cellular confinement systems are noted to vastly enhance the physical and mechanical properties of granular materials, thus enabling their use in load bearing applications (Koerner, 2005).

Table 4. 6 Displacement at 1,000,000 cycles for different base/sub base configurations under high load range (1.0-4.0) kip of fatigue load.

\begin{tabular}{|c|c|c|c|c|c|c|c|}
\hline $\begin{array}{c}\text { Low Load } \\
\text { Case } \\
\text { (kip) }\end{array}$ & $\begin{array}{c}\text { Plate } \\
\text { Diameter }\end{array}$ & Base & Woven & $\begin{array}{c}\text { Geogrid } \\
\text {-Woven }\end{array}$ & TDGC & $\begin{array}{c}8 \text { in. } \\
\text { Geoweb }\end{array}$ & $\begin{array}{c}\text { Percent } \\
\text { difference } \\
\text { from Base } \\
\text { to TDGC } \\
\text { value }\end{array}$ \\
\hline $1.0-4.0$ & 12 inch & 0.750 & 0.718 & 0.635 & 0.345 & 0.324 & $54.0 \%$ \\
\hline
\end{tabular}

Note: 1 inch $=25.4 \mathrm{~mm} ; 1 \mathrm{psi}=0.00689 \mathrm{MPa}$

The woven geotextile and geogrid-woven geotextile combinations provide base/sub base modulus or displacement performance enhancement with respect to the base case. Their 
improvements are about 50\% less than that of the 8 inch geoweb and TDGC. The TDGC provided a 54\% increase in the displacement performance, but this value is conservatively estimated because of the fact the base configuration was only tested for less than 100,000 cycles as it reached the displacement limit way short of the 1,000,000 cycles.

By analyzing the initial load vs. displacement response of each base/sub base configuration (Figure 4.9), it can be inferred that significant changes take place once a high range fatigue load is applied to the aggregate surface. Figure 4.9 shows how each specimen compared within the first 25,000 cycles. Alternative tests were conducted utilizing geogrid, woven geotextile fabric, and a TDGC (denoted as Geogrid-Woven -TDGC). The results are provided in Figure 4.9 which shows comparative responses for high range (1.0-4.0 kip) fatigue loading.

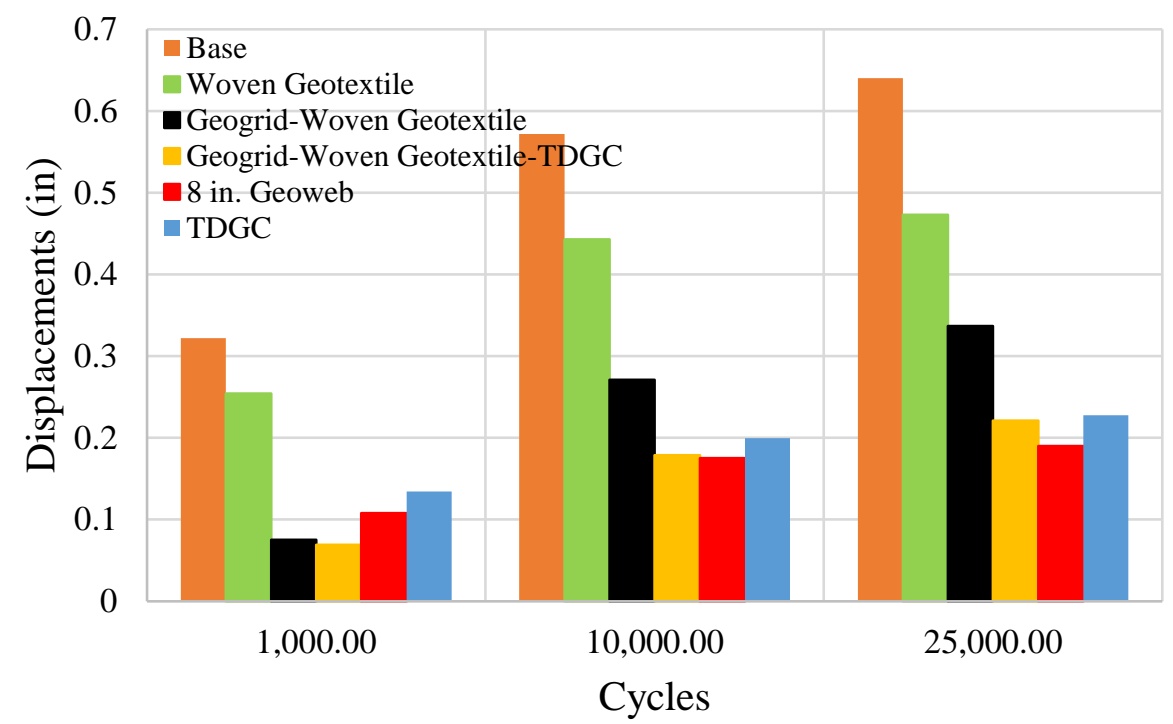

Figure 4. 9 Initial responses of specimens exposed to loads of 1-4 kip.

Trends plotted following the initial 100,000 cycles show TDGC, woven geotextile, geogrid-woven combination, and 8 in. geoweb slopes. Results show that after settlement took place, the TDGC displaces the least over the next 900,000 cycles (Figure 4.10). The addition of geogrid to the woven geotextile fabric provided stability in comparison to the woven tested independently. However, neither the woven nor the geogrid-woven geotextile combination resisted displacement at rates comparable to the 8 in. geoweb and TDGC. In all facets of dynamic testing, the 8 in. geoweb and the tire-derived geo-cylinder most closely react to vertical force application with AASHTO \#57 stone base/sub base. 


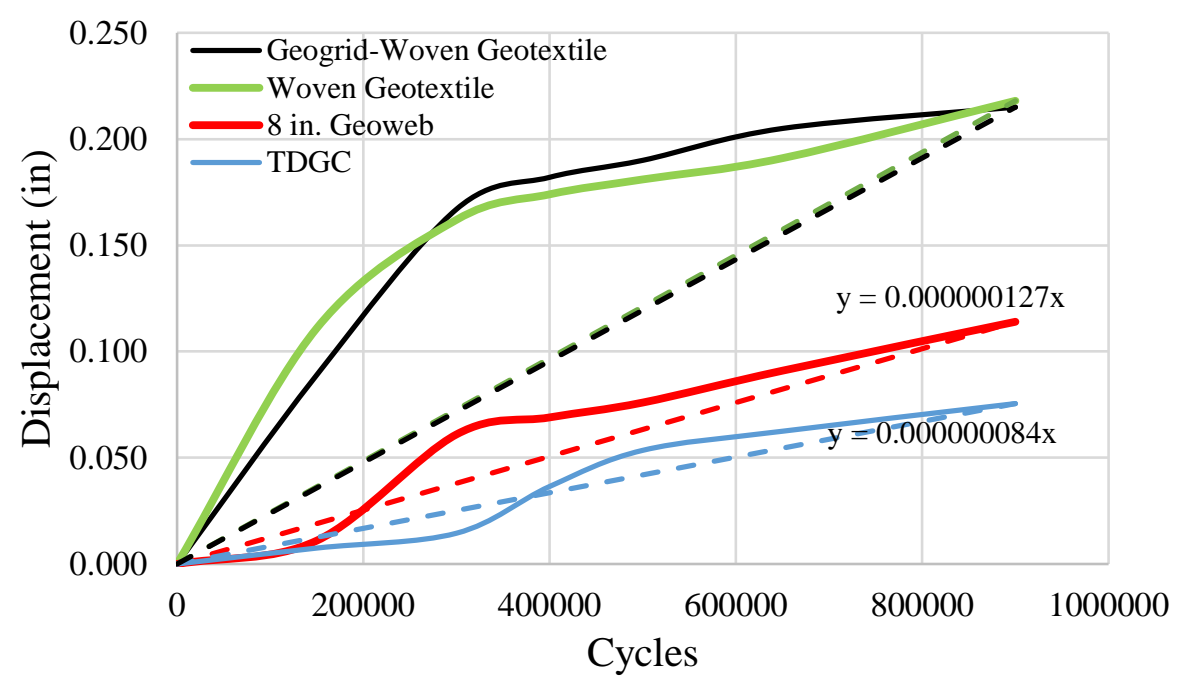

Figure 4. 10 Graphical trends following initial settlement for loads of 1-4 kip.

Similar to the number of cycles vs. displacement plot lower load cases, displacements and their trend lines were plotted for different configurations of geogrid-woven geotextile, woven geotextile, 8" geoweb, and TDGC configurations for higher fatigue load range cases (Figure 4.10). Trend lines are helpful in understanding the base/sub base performance with increased number of load cycles. The data represents slope trends after the first 100,000 cycles. The base configuration slope is not included as the displacement was very high within 100,000 cycles.

From Figure 4.10, woven geotextile and geogrid-woven geotextile base/sub base configurations show stabilized values of displacement after about 300,000 cycles of loading as compared to base case. It is intuitive that the addition of more reinforcement results in lower displacement. This is observed in the reduced slope of the geogrid-woven geotextile combination. The slope of the 8" inch geoweb is slightly higher than that of the TDGC; however, the TDGC had slightly higher initial displacement, but it settled and provided less incremental displacement over time. The TDGC provided a slope merely $50 \%$ less slope than that of the 8 inch geoweb. These values will be slightly different if the displacements during initial cycles are ignored.

\subsubsection{High Load Case ( 3 million cycles $\&$ Post 3 million static tests)}

The TDGC and the 8 in. geoweb were fatigue tested again at 1-4 kip at $2 \mathrm{~Hz}$ for 3 million cycles to further explore the relationship regarding the two specimens. The trends of the two specimens are plotted in Figure 4.11. Trends show that the specimens correlate well to one with the TDGC performing slightly more efficient in regards to vertical displacement. Static tests were 
conducted following the 3 million cycles to compare the initial static values to values obtained following intense fatigue conditions.

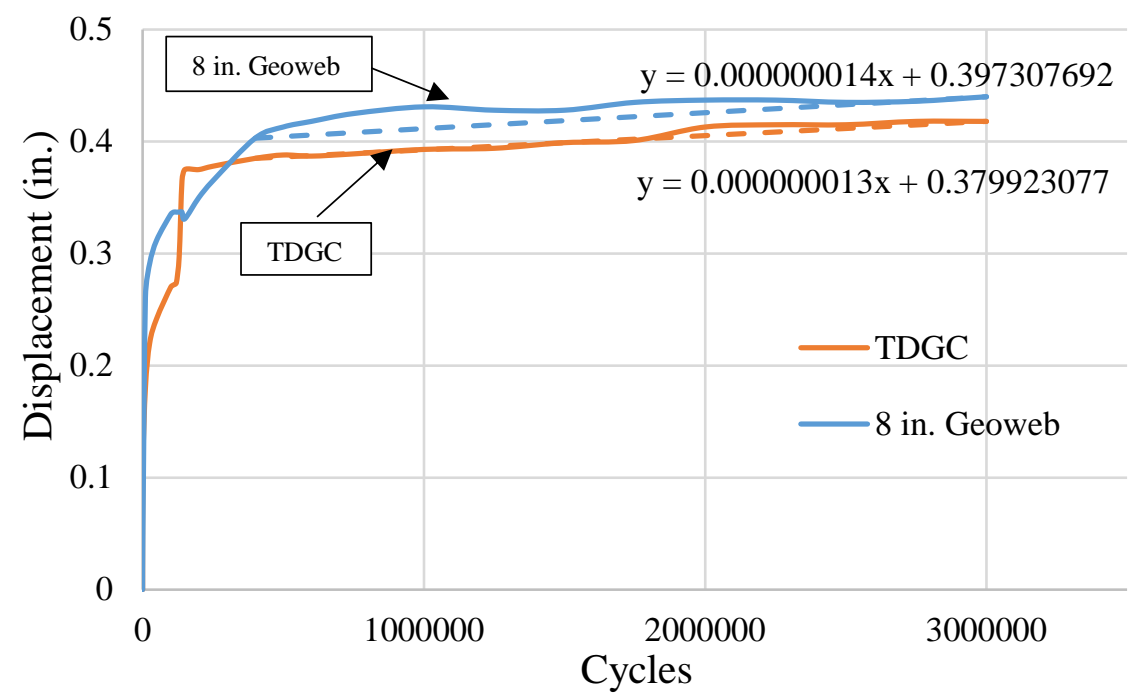

Figure 4. 11 Fatigue testing to 3 million cycles

The TDGC and geo-web/cell performed similarly when based on their slopes following the initial settlement points at approximately 400,000 cycles. It can be observed from Figure 4.11 that the trend lines of the slopes for TDGC and 8" geoweb stabilize after the initial settlement due to the overall behavior of the TDGC and geowebs. The data shows the role of initial settlement in the overall behavior. Both specimens were effective in dissipating the initial settlement; however, it was observed that the TDGC was able to sustain slightly better performance efficiency throughout the entire testing.

Following 3 million fatigue cycles, a series of static tests were conducted utilizing the fatigue testing setup at a displacement limit of 0.15 " to observe the post-fatigue response of the aggregate filled the TDGC and 8" geoweb. The collected data shows that the higher load was needed to reach the displacement limit of 0.15 " after 3 million cycles of loading as compared to the first cycle of load. The 8 " geoweb reached the 0.15 " limit with lower applied force than the TDGCs and aggregates within the TDGC may compact more efficiently over time (Figure 4.12). The TDGC was able to endure a load $\sim 50 \%$ greater than the 8 " geoweb before reaching the testing limit. This resulted in the TDGC obtaining a higher base/sub base modulus after exposure to the higher fatigue loads after 3 million cycles. 


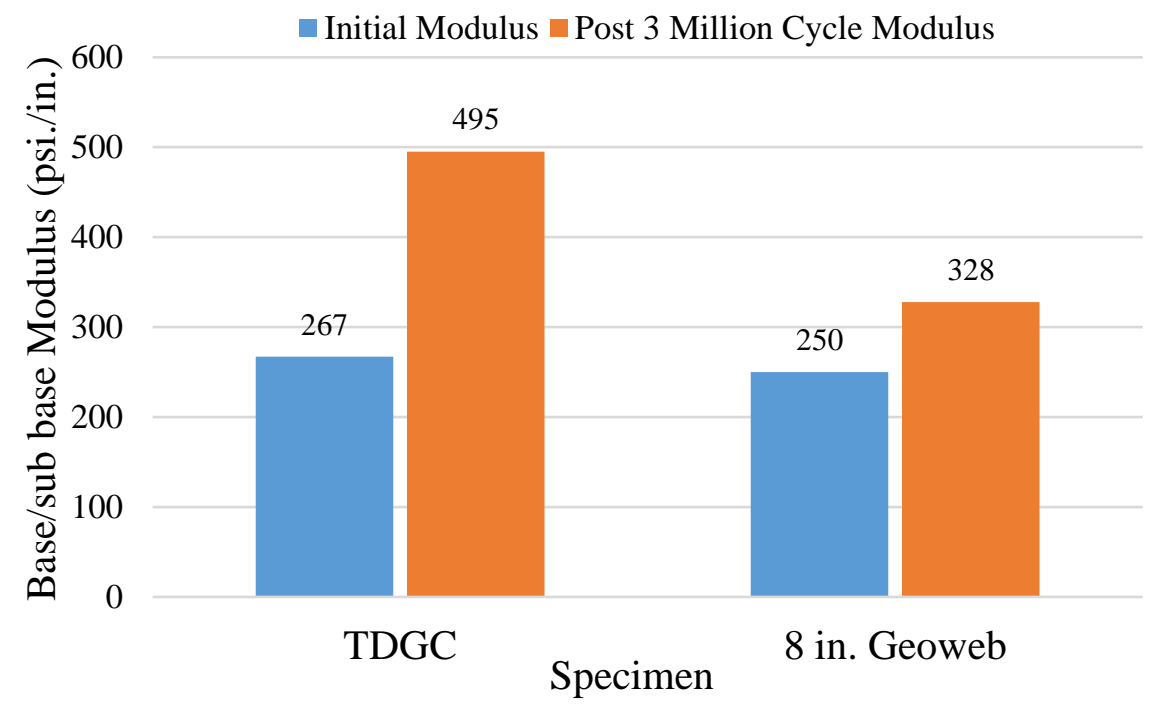

Figure 4. 12 Post 3 million static testing

\subsubsection{Hot-Mix Asphalt (HMA) and Portland Cement Concrete (PCC) Slab Testing}

Roadway testing on representative pavement section was conducted within the small testing bin. Three cast roadway slab sections were independently placed within the bin, and each was reinforced with a TDGC and 8" geoweb to compare the displacements from applied static loads. Materials used for casting were hot-mix asphalt (HMA) and Portland Cement Concrete (PCC). The asphalt was a Wearing-1 mix with a maximum specific gravity for pavement mixture at a value of 2.476. The HMA was comprised of $48 \%$ AASHTO \#8 limestone, $32 \% \mathrm{WV}$ sand, and $20 \%$ Monongahela sand. HMA has an approximate modulus of elasticity (E) spanning from $20 \mathrm{ksi}$ (temperature dependent) (Newcomb et al, 2002). The PCC slab was 3,000 psi concrete reinforced with \#5 Grade 60 rebar. Wet curing time of 28 days was allowed for the concrete slab. PCC has an approximated density of $0.0867 \mathrm{lb} / \mathrm{in}^{3}$ and a modulus of elasticity (E) of 4.5 million psi. PCC material property values are in accordance to a publication from the Federal Highway Administration (2012). The average surface area for each roadway section was 2'x2'. The PCC (rigid pavement) slab was cast at 11" thick, and the hot-mix asphalt (flexible pavement) was cast in two separate thicknesses of 9" and 5" (Figure 4.13). A set static loading force of 15 kip was applied individually on each roadway slab section (11" PCC slab, 9" HMA slab, and 5" HMA slab). Load was applied on each slab with corresponding base/sub base reinforcement configurations. By using a standard load condition, comparisons were made pertaining to the TDGC and 8"geoweb as shown in Figure 4.14. 


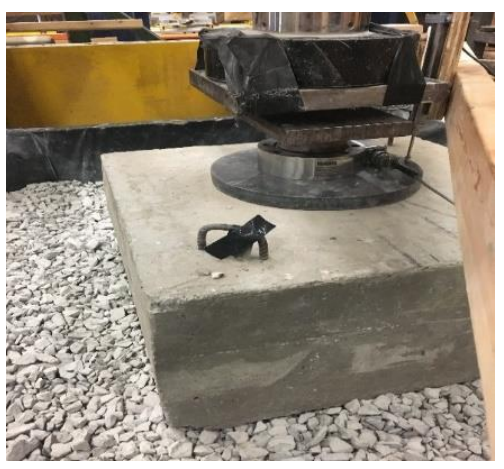

(a)

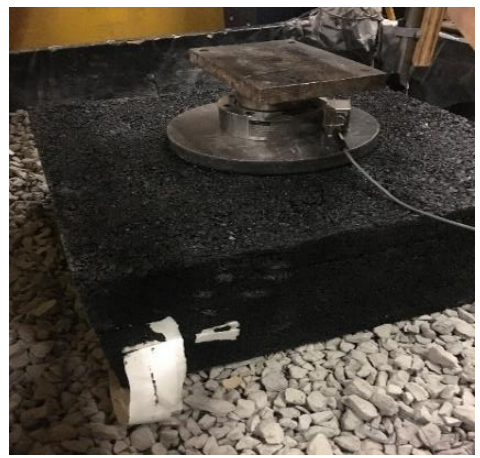

(b)

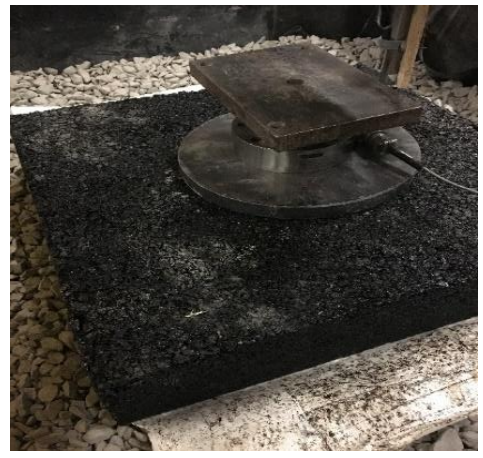

(c)

Figure 4. 13 Roadway slabs (a) 11" concrete (PCC) slab (b) 9" hot-mix asphalt (HMA) slab (c) 5 " hot-mix asphalt (HMA) slab

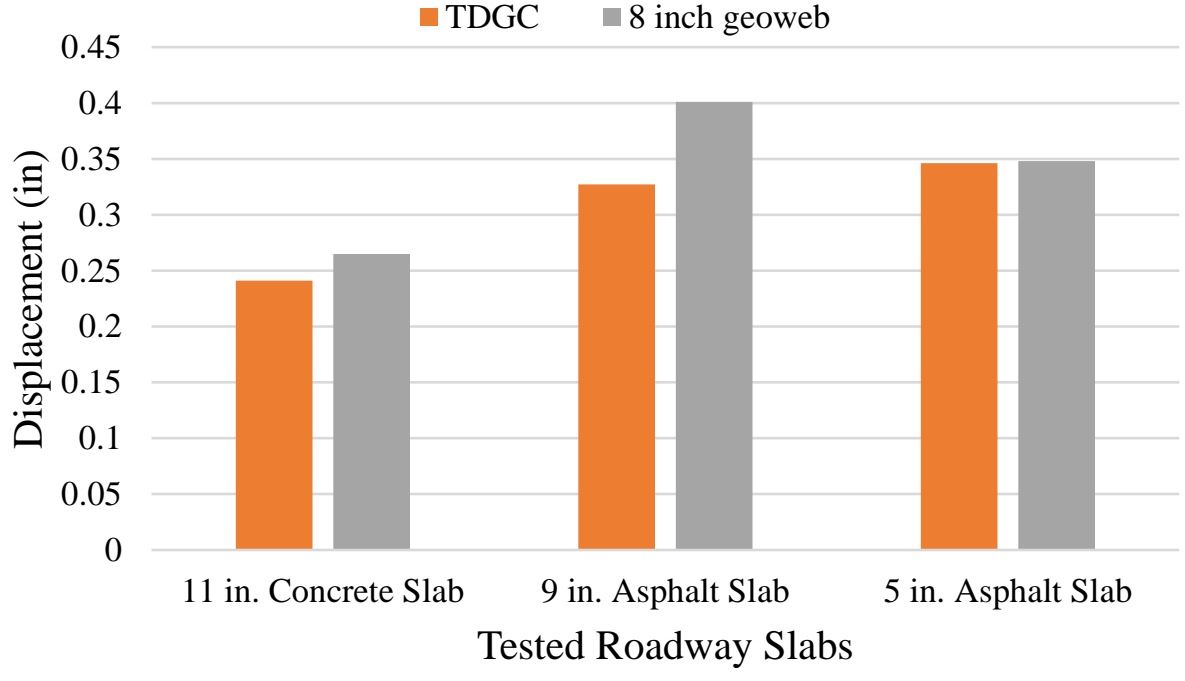

Figure 4. 14 Displacements of each slab type corresponding to TDGC and geoweb reinforcement 
Displacement were observed to be lower for the 5" and 9" HMA slab section. This can be attributed the flexibility of the pavement system and the force dissipation within the geocells as the pavement flexes. The slabs were able to rest on the expanded walls of the geowebs. This allowed the geoweb to turn into a stiffened matting system. The TDGC acted similarly when used as reinforcement underneath the roadway specimens. Field data will help aid understanding of the 8 " geowebs and TDGCs use as base/sub base reinforcement for roadway systems.

\subsection{Summary of Low Range and High Range Fatigue Load Tests}

The fatigue test data shows that the use of base/sub base improvement techniques helped in lowering the displacements in the base/sub base materials. The test data shows that 6 inch geoweb, 8 inch geoweb, and TDGCs all provide increases to base/sub base moduli. The 8 inch geoweb and TDGC perform similarly in different load cases. In the next chapter, an attempt is made to design pavements with the base/sub base property enhancing techniques discussed in this chapter of the thesis. 


\section{DESIGN SUMMARY AND CALCULATIONS}

The purpose of this chapter is to develop an ideal means to design, install, and use

tire-derived geo-cylinders, or TDGC, as an option for engineering practice to construct stronger base/sub base. This chapter provides case study overviews in which geowebs and TDGCs were used to provide reinforcement to pavement structures. Approximate design thicknesses and layer coefficients are proposed from computational methodologies derived from the 1993 AASHTO Design. A construction cost analysis for an HMA road is included at the end of this chapter.

\subsection{Supporting Case Studies}

The following case studies show the implementation details of geowebs and TDGCs (mechanical concrete) in different settings for enhancing the pavement performance in real world applications. In addition, design examples with and without TDGCs (mechanical concrete) are provided along with cost comparison. At the end of the chapter, cost analysis for a typical roadway (flexible pavement) system is provided for conventional and mechanical concrete pavement systems.

\subsubsection{Re-Construction of Major District Road in Nashik with StrataWeb, (Nashik, India)}

StrataWeb, 2014

In 2014, S M Autade Constructions Pvt. Ltd installed geoweb, or geocells, in Sinnar Taluka, District Nashik, India. Geoweb was used to enhance the subgrade efficiency of expansive soils (StrataWeb, 2014). The roadway was exposed to high traffic volumes due to the nearby sugar cane industry. The expansive soils with their high shrink-swell behavior created pavement deterioration. This problem was more severe during monsoons and intensified rainfall conditions. The road was constructed from the base criteria put forth by the Indian Road Congress (IRC), and the solution consisted of removal of existing portions of subgrade and redressing the subgrade. Sand was applied following the watered compaction of the dressed material. StrataWeb SW 356150 was placed over the sand and reinforced with metal spikes. Granular material was placed within each cell of the StrataWeb to a depth of $25 \mathrm{~mm}\left(\sim 1^{\prime \prime}\right)$ above the cellular structure. Vibratory compactors were utilized to level the surface and allow for immediate traffic flow. It is reported that the geoweb contributed to maintenance cost reduction for roadway along with huge savings in time and money. The issues with expansive soils were overcome by the uplift resistance of the 
overlay and bridging of the shrinkage voids between the pavement and subgrade. Overall, it is reported that the riding quality and road performance were improved with geoweb installation.

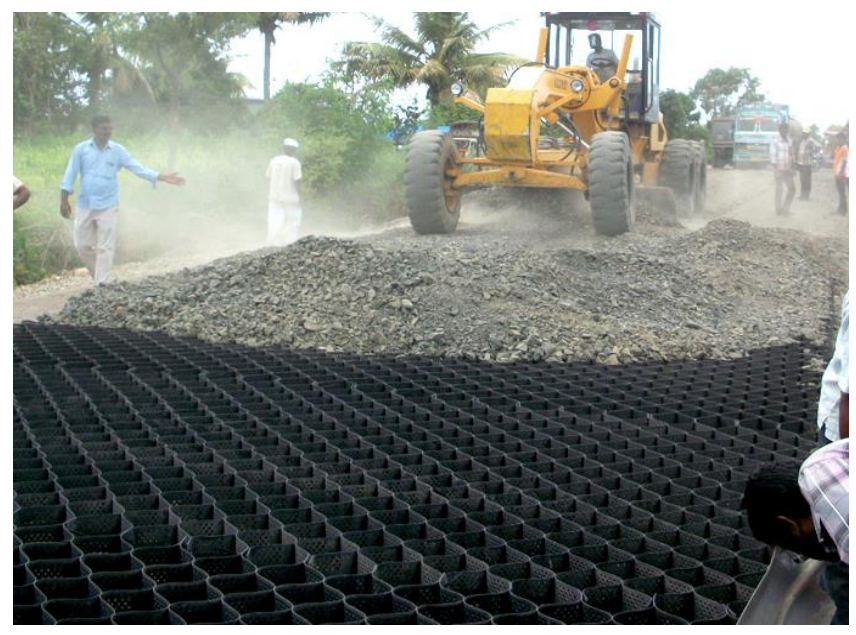

(a)

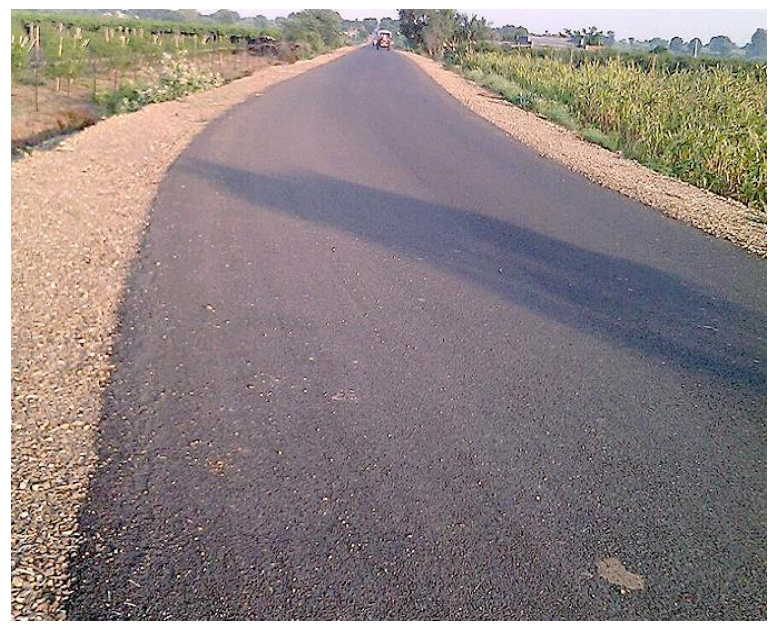

(b)

Figure 5. 1 (a) Geoweb reinforced roadway under construction (b) Final reinforced roadway in Nashik, India (StrataWeb 2014)

\subsubsection{Doddridge County, WV Division of Highways Mechanical Concrete ${ }^{\circledR}$ Roadway Installation in 2009}

This field implementation of Mechanical Concrete® consisting of tire-derived geocylinders was carried out in proximity to Morgan's Run Road/Israel Fork (Doddridge County, WV) and consisted of 350 cylinders of 28" diameter x 8" width. Cylinders were placed adjacent to one another and placed without separation fabric. The mechanical concrete was installed in an area prone to flooding conditions that resulted due to seasonal winter snowfall and spring rains. The tire-derived geo-cylinders of Mechanical Concrete ${ }^{\circledR}$ cells were filled with AASHTO \#57 stone and then topped with $6 "$ of $3 / 4$ crusher run limestone. No compaction was provided to the aggregate infill of the Mechanical Concrete®. The rehabilitated road experienced intense loading conditions as a result of traffic related to oil and gas drilling equipment, service vehicles, and heavy construction equipment hauling vehicles. Due to seasonal and flash floods in the area, the overlying material gets washed away occasionally. However, it is stated that the West Virginia Division of Highway crew don't have to exert immense time and effort in correcting the roadway. The tire-derived geo-cylinders were observed to remain intact and swift repair was possible in extreme conditions, if necessary. After 2.5 years following the installation, it was concluded that 
the Mechanical Concrete ${ }^{\circledR}$ systems can enhance the performance of low volume unpaved roadways exposed to heavy vehicular loads. The cylinders can provide washout prevention for roadway shoulders and resistance against water damages from moderate flooding conditions.

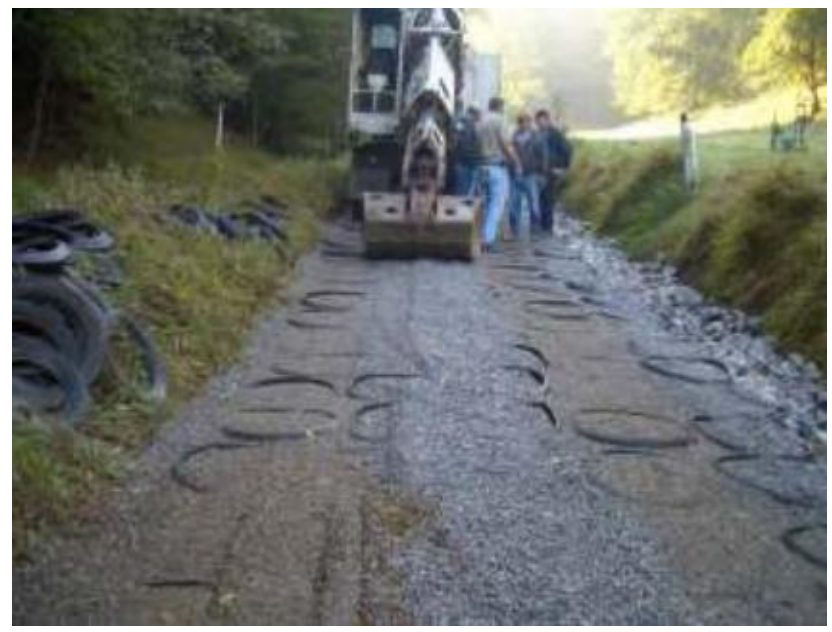

(a)

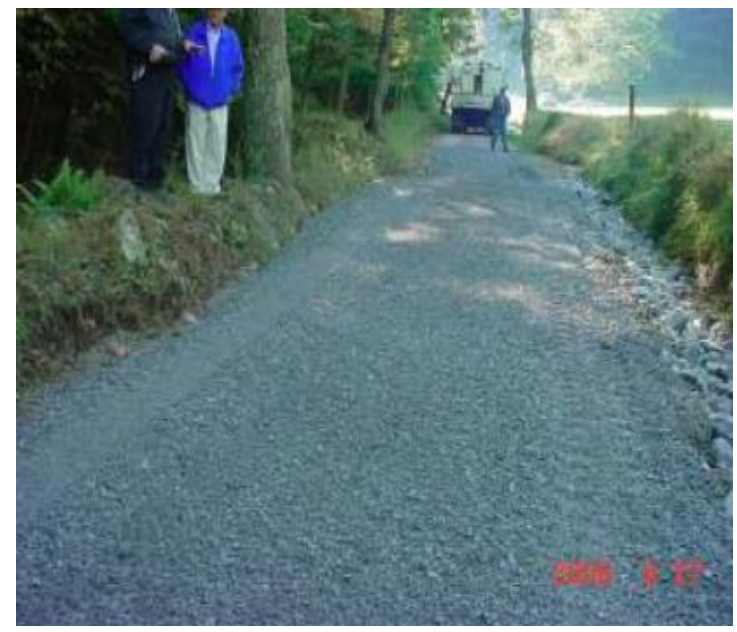

(b)

Figure 5. 2 (a) Mechanical concrete base in Doddridge County, WV

(b) Wearing surface (Mechanical Concrete $® 2009$ )

\subsection{Flexible/Rigid Pavement Design Examples}

The following section provides a design procedure for flexible and rigid pavements based on the AASHTO Road Test design guidelines (1993) and data obtained from the Morgantown Metropolitan Planning Organization (MPO). This design provides a conservative approach for providing a basis of thickness design and layer coefficient design for base/sub base layers of the pavement (Figure 5.3), and the results are compared by increasing the modulus $\left(\mathrm{M}_{\mathrm{R}}\right)$ value of base/sub base with tire-derived geo-cylinder reinforcement by $34 \%$ based on the laboratory results. The design examples show reductions between base condition without reinforcement and base reinforced with mechanical concrete comprising of in material quantity of tire-derived geocylinders. The AASHTO 1993 design guidelines consider different materials used for layers 2 and 3; however, in the design example with Mechanical Concrete ${ }^{\circledR}$, AASHTO \#57 aggregates are used throughout the underlying roadway surface as base/sub base (layers 2 and 3). 


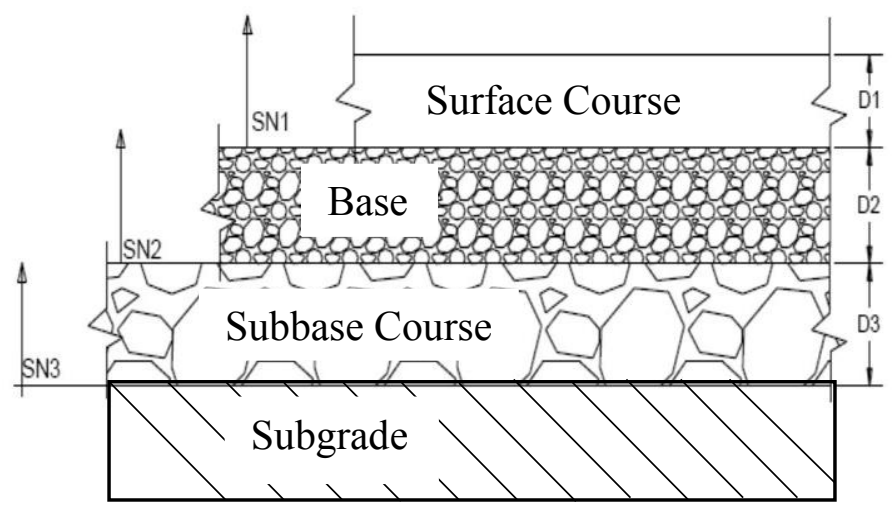

Figure 5. 3 Typical layers for a pavement system

This section uses commonly used coefficients based on engineering judgement or values suggested by the 1993 AASHTO Road Test design procedures (AASHTO Road Test and "Traffic and Highway Engineering, 4th Edition"). All abbreviations used in the design example are provided below and appropriate engineering constants used in the example are also mentioned. 


\subsubsection{Proposed Flexible Pavement Design Example}

\section{List of Abbreviations and Key Variables:}

TDGC $=$ tired-derived geo-cylinder

$\mathrm{SN}_{\mathrm{i}}=$ structural number of layer $\mathrm{i}$

$\mathrm{D}_{\mathrm{i}}=$ depth of layer of layer $\mathrm{i}$

$\mathrm{D}^{*}=$ rounded layer depth (to nearest half inch)

Aggregate Depth $_{\text {tot }, \text { no }}=$ total depth of aggregate with no reinforcement

Aggregate Depth $h_{\text {tot,rein }}=$ total depth with TDGC reinforcement

Volume $_{\text {aggr }, \text { no }}=$ volume of aggregate with no reinforcement

Volume $_{\text {aggr }, \text { rein }}=$ volume of aggregate with TDGC reinforcement

Volume $_{\text {aggr, hma no }}=$ volume of HMA with no reinforcement

Volume $_{\text {aggr }, \text { hma rein }}=$ volume of HMA with TDGC reinforcement

$\mathrm{a}_{\mathrm{i}}=$ structural coefficient of layer $\mathrm{i}\left(\mathrm{a}_{1}, \mathrm{a}_{2}, \mathrm{a}_{3}\right)$

$\mathrm{m}_{\mathrm{i}}=$ saturation coefficient of layer $\mathrm{i}\left(\mathrm{m}_{1}, \mathrm{~m}_{2}, \mathrm{~m}_{3}\right)$

Volume $_{T D G C, \text { out }}=$ TDGC outer dimensional volume

Volume $_{T D G C, \text { in }}=$ TDGC inner dimensional volume

$\Delta$ Volume $_{T D G C}=$ change in volume form TDGC $\left(\right.$ Volume $_{T D G C, \text { out }}-$ Volume $\left._{T D G C, \text { in }}\right)$

\section{Units Associated with Calculations:}

$\mathrm{ESAL}=$ equivalent single axle load

psi $=$ pounds per square inch

in. $=$ inch

$\mathrm{ft} .=$ feet

$\mathrm{SF}=\mathrm{ft}^{2}$

$\mathrm{CY}=$ cubic yards 
This design example incorporates all assumptions and engineering constants that were either selected based on the engineering judgement from the corresponding tables and charts from the 1993 AASHTO Road Test design guidelines, The Asphalt Institute, or the Federal Highway Administration (FHWA). All assumptions and engineering values used in nine steps (1-9) of the design example are appropriately listed in the following steps. At the end of the following nine steps, a comparison of layer thicknesses and structural coefficients are provided for pavement sections with and without TDGC reinforcement (Mechanical Concrete ${ }^{\text {) }) ~ i n ~ t h e ~ f o r m ~ o f ~ s u m m a r y ~}$ tables (Tables 5.1 and 5.2). Similar to the nine step flexible pavement design example, a twelve step rigid pavement example is also provided in this chapter with cost comparisons based on material savings.

Step 1. Analysis period $=20$ years

Growth rate $=4 \%$

(Assumed from The Asphalt Institute, 1991)

Step 2. Reliability, $\mathrm{R}=80 \%$

Standard Normal Variate, $Z_{R}=-0.841$ from Figure 5.3

(pgs. I-62 \& II-9 of AASHTO Road Test), Interpolated values for rural collectors.

\begin{tabular}{cc} 
Table 4.1. & $\begin{array}{l}\text { Standard Normal Deviate }\left(\mathbf{Z}_{\mathbf{R}}\right) \text { Values } \\
\text { Corresponding to Selected Levels of } \\
\text { Reliability }\end{array}$ \\
\hline $\begin{array}{c}\text { Reliability, } \\
\text { R (percent) }\end{array}$ & $\begin{array}{c}\text { Standard Normal } \\
\text { Deviate, } \mathbf{Z}_{\mathbf{R}}\end{array}$ \\
\hline 50 & -0000 \\
60 & -0253 \\
70 & -0524 \\
75 & -0674 \\
80 & -0841 \\
85 & -1037 \\
90 & -1282 \\
91 & -1340 \\
92 & -1405 \\
93 & -1476 \\
94 & -1555 \\
95 & -1645 \\
96 & -1751 \\
97 & -1881 \\
98 & -2054 \\
99 & -2327 \\
999 & -3090 \\
9999 & -3750 \\
\hline
\end{tabular}

Figure 5. 4 Standard normal variant selection for flexible pavement 
Step 3. Standard deviation, $S_{0}=0.45$ from Figure 5.5

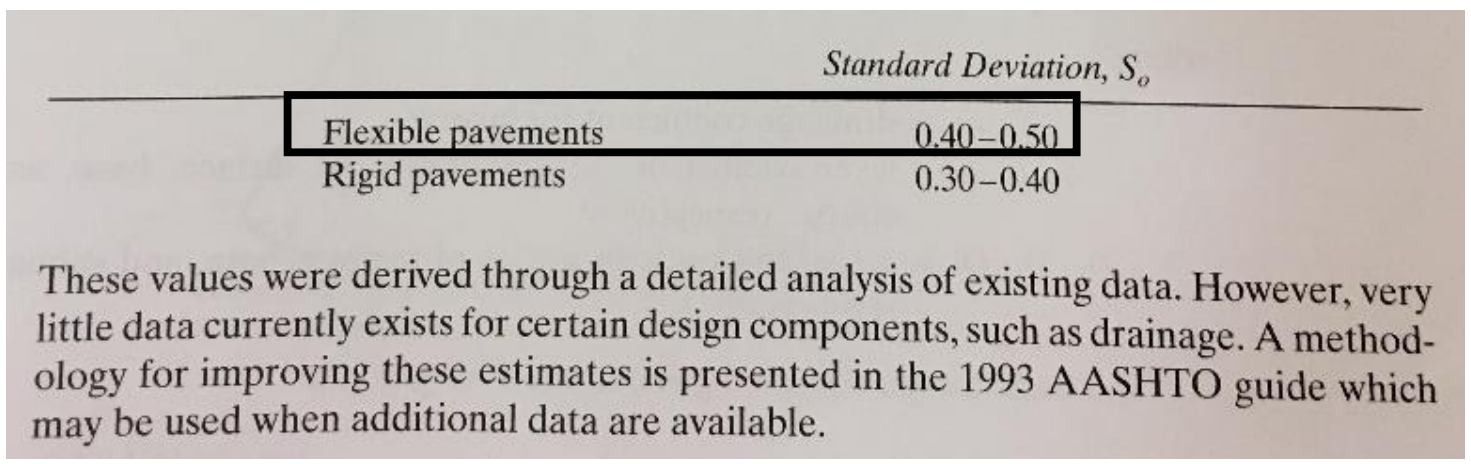

Figure 5. 5 Standard deviation for flexible pavement

(pg. 1047, Garber and Hoel, 2009), Interpolated from flexible pavement values.

Step 4. Two- lane road with one lane per direction. The assumed directional distribution of 18-kip ESAL loads. (Road layout is typical for West Virginia rural roadways)- pg. II-9 of 1993 AASHTO Road Test.

\begin{tabular}{cc}
$\begin{array}{c}\text { Number of Lanes } \\
\text { in Each Direction }\end{array}$ & $\begin{array}{c}\text { Percent of 18-kip ESAL } \\
\text { in Design Lane }\end{array}$ \\
\hline 1 & 100 \\
2 & $80-100$ \\
3 & $60-80$ \\
4 & $50-75$ \\
\hline
\end{tabular}

Figure 5. 6 Percent of 18 kip ESALS in lane of design

Step 5. Initial serviceability index, $\mathrm{p}_{\mathrm{i}}=4.2$ (for flexible pavement), Terminal serviceability index where $\mathrm{p}_{\mathrm{t}}=2.0$ (assumed lower classification highway)

(pg. 1035, Garber and Hoel, 2009 and pg. II-10 of AASHTO Road Test)

Step 6. Original CBR used for unreinforced calculations $=65$

Modulus estimate $=27,700 \mathrm{lb} / \mathrm{in}$.

(pgs. II-19 \& II-21 of AASHTO Road Test) - (refer to the chart used in assumption 10.) 
Step 7. Growth factor, $\mathrm{G}_{\mathrm{jt}}=29.78$ (Assumed from The Asphalt Institute, 1991)

Step 8. Drainage conditions are considered fair for this calculation. Quality of drainage $=$ 1 week (fair) for assumed water removal conditions (Figure 5.7).

(pg. II-22 AASHTO Road Test)

\begin{tabular}{ll} 
Quality of Drainage & Water Removed Within \\
\hline Excellent & 2 hours \\
Good & 1 day \\
Fair & 1 week \\
Poor & 1 month \\
Very poor & (water will not drain) \\
\hline
\end{tabular}

Figure 5.7 Quality of drainage

Step 8 reflects the calculation for the drainage coefficients $\left(\mathrm{m}_{\mathrm{i}}\right)$ for the base/sub base. The value where $\mathrm{m}_{\mathrm{i}}=1.0$ is due to the consideration of a fair drainage condition and that pavement is exposed to moisture levels approaching saturation 5-25\% of the time.

(pg. II-25 AASHTO Road Test), Assumed fair drainage quality and 5-25\% moisture levels (Figure 5.8).

\begin{tabular}{|c|c|c|c|c|}
\hline \multirow[b]{2}{*}{$\begin{array}{l}\text { Quality of } \\
\text { Drainage }\end{array}$} & \multicolumn{4}{|c|}{$\begin{array}{l}\text { Percent of Time Pavement Structure is Exposed } \\
\text { to Moisture Levels Approaching Saturation }\end{array}$} \\
\hline & $\begin{array}{c}\text { Less Than } \\
1 \%\end{array}$ & $1-5 \%$ & $5-25 \%$ & $\begin{array}{c}\text { Greater Than } \\
\mathbf{2 5 \%}\end{array}$ \\
\hline Excellent & $140-135$ & $135-130$ & $130-120$ & 120 \\
\hline Good & $135-125$ & $125-115$ & $115-100$ & 100 \\
\hline Fair & $125-115$ & $115-105$ & $100-080$ & 080 \\
\hline Poor & $115-105$ & $105-080$ & $080-060$ & 060 \\
\hline Very poor & $105-095$ & 0 95-0 75 & $075-040$ & 040 \\
\hline
\end{tabular}

Figure 5. 8 Moisture exposure on flexible pavement structures

Step 9. The structural coefficients $\left(a_{i}\right)$ in Figure 5.9 are calculated with respect to the wearing coarse, base, and subbase. The structural coefficients are used to convert the actual layer thicknesses to structural numbers (SN). This calculation assumes uniform aggregate throughout the pavement system's underlying surface. The HMA a 1 was assumed to be 0.45 for both non-TDGC and TDGC reinforced. Utilizing a value of 27,700 psi for the unreinforced base and subbase moduli $\mathrm{a}_{2}$ and $\mathrm{a}_{3}$ are calculated to be 0.13 . By applying the $34 \%$ increase of moduli observed from static testing in the small bin, $a_{2}$ and $a_{3}$ are calculated to be approximately 0.165 . Recommended $a_{i}$ = values obtained from pg. II-19 \& II-21 AASHTO Road Test with respect to layer CBR. 
Unreinforced layer: $\mathrm{a}_{1}=0.45, \mathrm{a}_{2}=0.13$, and $\mathrm{a}_{3}=0.13$.

Reinforced layer: $\mathrm{a}_{1}=0.45, \mathrm{a}_{2}=0.165$, and $\mathrm{a}_{3}=0.165$.

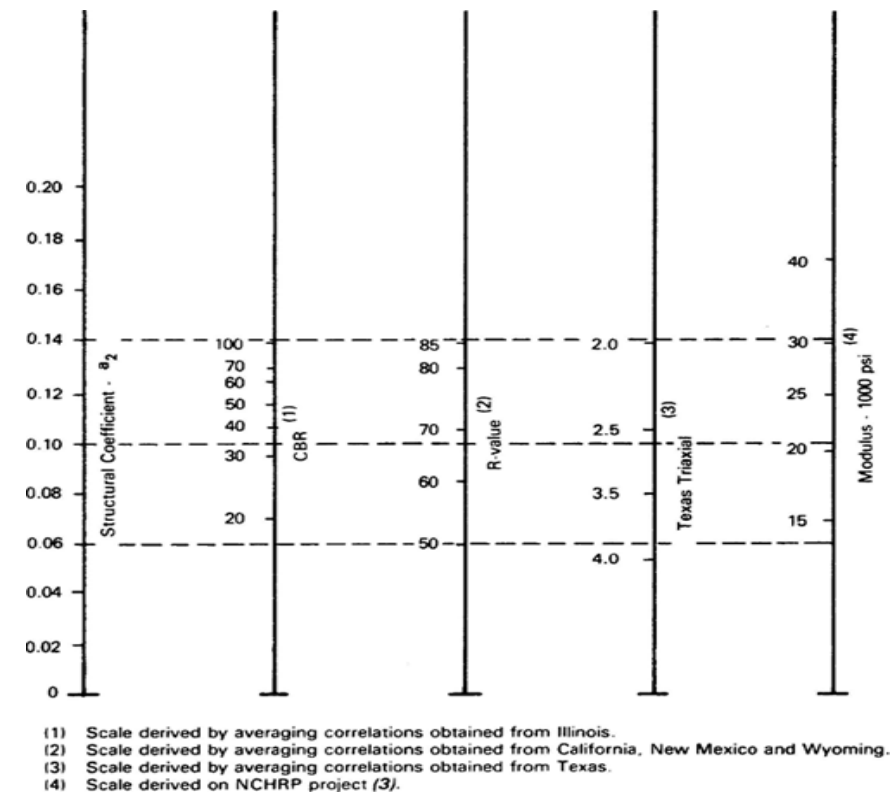

(a)

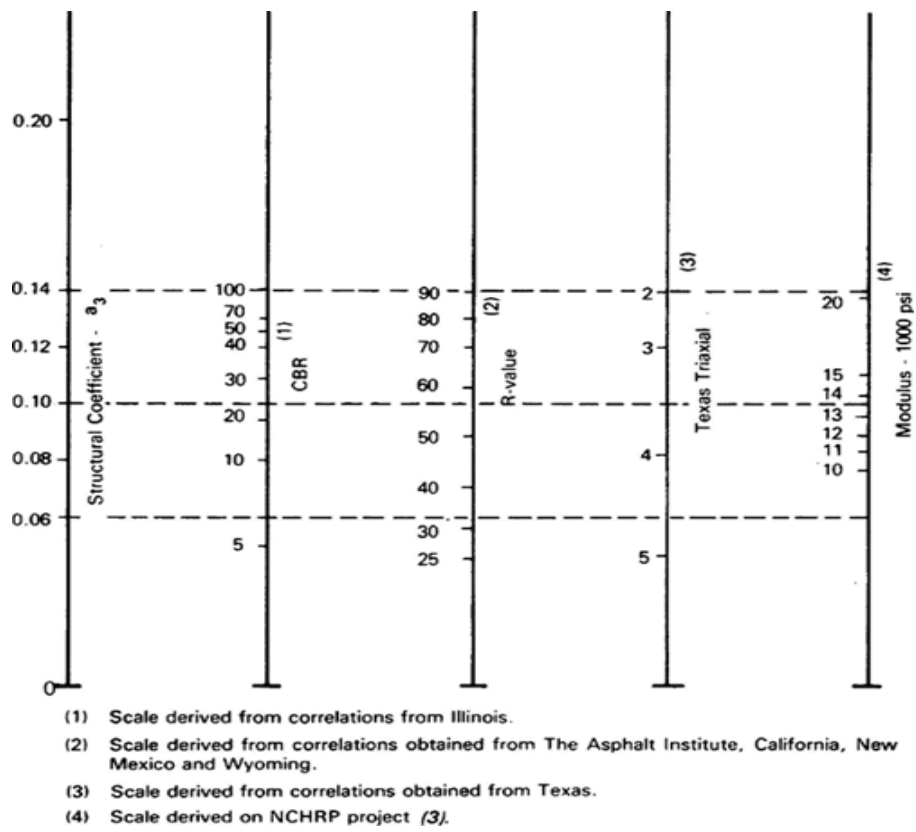

(b)

Figure 5. 9 Graphs to determine CBR and structural coefficients (a) Variation in granular base layer coefficient $\left(\mathrm{a}_{2}\right)$ with various base strength parameters (b) Variation in granular sub base layer coefficient $\left(\mathrm{a}_{2}\right)$ with various structure parameter 
**Design ESAL is assumed to be $\mathbf{1 , 0 6 0 , 0 0 0} * *$

(Equation 5.1) Solving the AASHTO basic design equation for flexible pavement:

$$
\begin{aligned}
& \log _{10} W_{18}=Z_{R} S_{o}+9.36 \log (S N+1)-0.20+\frac{\log _{10}\left[\frac{\Delta P S I}{4.2-1.5}\right]}{0.40+\left[1094 /(S N+1)^{5.19}\right]} \\
& +2.32 \log _{10} M_{R}-8.07 \\
& W_{18}=10 \quad Z_{R} S_{o}+9.36 \log (S N+1)-0.20+\frac{\log _{10}\left[\frac{\Delta P S I}{4.2-1.5}\right]}{0.40+\left[1094 /(S N+1)^{5.19}\right]}+2.32 \log _{10} M_{R}-8.07 \\
& W_{18}=10^{-.841 * 0.45+9.36 \log (3.01+1)-0.20+\frac{\log _{10}\left[\frac{2.2}{4.2-1.5}\right]}{0.40+\left[1094 /(3.01+1)^{5.19}\right]}}+2.32 \log _{10}(8400)-8.07
\end{aligned}
$$

Where:

$$
\begin{gathered}
\mathrm{Z}_{\mathrm{R}}=-0.841 \\
\mathrm{~S}_{\mathrm{o}}=0.45 \\
\mathrm{SN}=3.01 \text { from layer thickness calculation } \\
\Delta \mathrm{PSI}=\mathrm{p}_{\mathrm{i}}-\mathrm{p}_{\mathrm{t}}=4.2-2.0=2.2 \\
\mathrm{M}_{\mathrm{R}}=8,400 \mathrm{psi}
\end{gathered}
$$

Data extrapolation, $\mathrm{W}_{18}$ is found to be 1,060,000 ESALS. The structural number $(\mathrm{SN})$ is the structural requirement needed to design for traffic loadings. The number expresses the structural strength of the pavement required for combinations of soil strength, equivalent singleaxle loadings (ESALS), and environment. The following steps provide the summarization for determining the SN for non-TDGC and TDGC reinforced HMA pavement.

Using Figure 3.1, pg. II-32 in AASHTO Road Test:

$$
\begin{aligned}
& S N_{1} \cong 1.94 \text { and } a_{1}=0.45 \\
& D_{1}=\frac{S N_{1}}{a_{1}}=\frac{1.94}{0.45}=4.31 \text { inches }
\end{aligned}
$$


Rounding to nearest half inch: $D^{*}{ }_{1}=4.50$ inch

$$
\begin{gathered}
\therefore S N^{*}{ }_{1}=a_{1} \times D^{*}{ }_{1}=0.45 \times 4.50 \text { inch } \approx 2.025 \\
S N^{*}{ }_{1}=2.025 \\
\therefore D^{*}{ }_{2} \geq \frac{S N_{2}-S N^{*}}{a_{2} \times m_{1}} \\
D^{*}{ }_{2} \geq \frac{1.94-2.025}{0.13 \times 1.0}=-0.65 \text { inch } \\
S N^{*}{ }_{2}=a_{2} \times m_{2} \times D^{*}{ }_{2}+S N_{1} \\
S N^{*}{ }_{2}=0.13 \times 1.0 \times-0.65 \text { inch }+1.94=1.86 \\
D^{*}{ }_{3} \geq \frac{S N_{3}-S N^{*}}{a_{3} \times m_{3}} \\
D^{*}{ }_{3} \geq \frac{3.01-1.86}{0.13 \times 1.0}=8.85 \text { inch }
\end{gathered}
$$

Calculated the volume (CY) with respect to the aggregate depth. Values were not rounded to show actual change instead of utilizing the AASHTO required minimums for design thicknesses (1993 AASHTO Road Test section 3.1.4).

$$
\begin{gathered}
\text { Aggregate Depth } h_{\text {tot }}=D^{*}{ }_{3}-D^{*}{ }_{2} \\
\text { Aggregate Dept } h_{\text {tot }, n o}=8.85 \text { inch }+(-0.65 \text { inch })=8.20 \text { inch } \\
\text { Volume }_{\text {aggr,no }}=\frac{\text { length } x \text { width } x \text { depth }}{27 \mathrm{ft}^{3}} \\
\text { Volume }_{\text {aggr,no }}=\frac{5,280 \mathrm{ft} . \times 28 \mathrm{ft} . \times\left(\frac{8.20 \mathrm{inch}}{12 \text { inch }}\right)}{27 \mathrm{ft} .{ }^{3}}=\mathbf{3 , 7 4 2 ~ C Y}
\end{gathered}
$$

*Note: All calculations were performed in the same exact manner except with a $34 \%$ increase in $M_{R}$ value with respect to the assumed value of $M_{R}=27,700$ from a $C B R=65^{*}$

\section{With TDGC reinforcement:}

Using Figure 3.1, pg. II-32 in AASHTO Road Test:

$$
\begin{aligned}
& S N_{1} \cong 1.73 \text { and } a_{1}=0.45 \\
& D_{1}=\frac{S N_{1}}{a_{1}}=\frac{1.73}{0.45}=3.84 \text { inches }
\end{aligned}
$$

Rounding to nearest half inch: $D^{*}{ }_{1}=4.0$ inch 


$$
\begin{gathered}
\therefore S N^{*}{ }_{1}=a_{1} \times D^{*}{ }_{1}=0.45 \times 4.0 \text { inch } \approx 1.8 \\
S N^{*}{ }_{1}=1.8 \\
\therefore D^{*}{ }_{2} \geq \frac{S N_{2}-S N^{*}{ }_{1}}{a_{2} \times m_{1}} \\
D^{*}{ }_{2} \geq \frac{1.73-1.8}{0.165 \times 1.0}=-0.424 \text { inch } \\
S N^{*}{ }_{2}=a_{2} \times m_{2} \times D^{*}{ }_{2}+S N_{1} \\
S N^{*}=0.13 \times 1.0 \times-0.424 \text { inch }+1.73=1.44 \\
D^{*}{ }_{3} \geq \frac{S N_{3}-S N^{*}}{a_{3} \times m_{3}} \\
D^{*}{ }_{3} \geq \frac{3.01-1.44}{0.165 \times 1.0}=9.50 \text { inch }
\end{gathered}
$$

Calculated the volume (CY) with respect to the aggregate depth. Values were not rounded to show actual change instead with the utilization of the AASHTO minimums for design thicknesses (1993 AASHTO Road Test section 3.1.4).

$$
\begin{aligned}
& \text { Aggregate Depth tot,rein }=D^{*}{ }_{3}-D^{*}{ }_{2} \\
& \text { Aggregate Depth }_{\text {tot }, \text { rein }}=9.50 \text { inch }+(-0.424 \text { inch })=9.01 \text { inch } \\
& \text { Volume }_{\text {aggr,rein }}=\frac{\text { length } x \text { width } x \text { depth }}{27 \mathrm{ft}^{3}} \\
& \text { Volume }_{\text {aggr,rein }}=\frac{5,280 \mathrm{ft} . \times 28 \mathrm{ft} . x\left(\frac{9.01 \mathrm{inch}}{12 \mathrm{inch}}\right)}{27 \mathrm{ft.} .^{3}} \approx \mathbf{4 , 1 1 1 ~ C Y}
\end{aligned}
$$

\section{Summary Tables of Calculated Thickness and Structural Numbers (SN)}

Table 5. 1 Proposed summary for no TDGC reinforcement road base/sub base

\begin{tabular}{|c|c|c|c|}
\cline { 2 - 4 } \multicolumn{1}{c|}{} & \multicolumn{3}{|c|}{$\begin{array}{c}\text { Summary of Thicknesses and SN for } \\
\text { No Reinforcement }\end{array}$} \\
\cline { 2 - 4 } & $\begin{array}{c}\text { Layer 1 } \\
(\mathrm{HMA})\end{array}$ & $\begin{array}{c}\text { Layer } 2 \\
(\text { Base })\end{array}$ & $\begin{array}{c}\text { Layer 3 } \\
(\text { Subbase })\end{array}$ \\
\hline SN & $1.94\left(\mathrm{SN}_{1}\right)$ & $1.86\left(\mathrm{SN}_{2}\right)$ & $3.01\left(\mathrm{SN}_{3}\right)$ \\
\hline Thickness, or Depth $\left(\mathrm{D}_{\mathrm{i}}\right)$ (not AASHTO min.); inch & $4.31\left(\mathrm{D}_{1}\right)$ & $-0.65\left(\mathrm{D}_{2}\right)$ & $8.85\left(\mathrm{D}_{3}\right)$ \\
\hline Structural Coefficient $(\mathrm{a})$ & $0.45\left(\mathrm{a}_{1}\right)$ & $0.13\left(\mathrm{a}_{2}\right)$ & $0.13\left(\mathrm{a}_{3}\right)$ \\
\hline Saturation Coefficient $(\mathrm{m})$ & & $1.0\left(\mathrm{~m}_{2}\right)$ & $1.0\left(\mathrm{~m}_{3}\right)$ \\
\hline
\end{tabular}


Table 5. 2 Proposed summary for TDGC reinforcement in the road base/sub base (34\% increase in performance applied) modulus from static testing)

\begin{tabular}{|c|c|c|c|}
\cline { 2 - 4 } \multicolumn{1}{c|}{} & \multicolumn{3}{c|}{$\begin{array}{c}\text { Summary of Thicknesses and SN } \\
(34 \% \text { Increase })\end{array}$} \\
\cline { 2 - 4 } \multicolumn{1}{c|}{} & $\begin{array}{c}\text { Layer 1 } \\
\text { (HMA) }\end{array}$ & $\begin{array}{c}\text { Layer 2 } \\
(\text { Base })\end{array}$ & $\begin{array}{c}\text { Layer 3 } \\
(\text { Subbase })\end{array}$ \\
\hline SN & $1.73\left(\mathrm{SN}_{1}\right)$ & $1.44\left(\mathrm{SN}_{2}\right)$ & $3.20\left(\mathrm{SN}_{3}\right)$ \\
\hline Thickness, or Depth $\left(\mathrm{D}_{\mathrm{i}}\right)$ (not AASHTO min.); inch & $3.84\left(\mathrm{D}_{1}\right)$ & $-0.424\left(\mathrm{D}_{2}\right)$ & $9.5\left(\mathrm{D}_{3}\right)$ \\
\hline Structural Coefficient $(\mathrm{a})$ & $0.45\left(\mathrm{a}_{1}\right)$ & $0.165\left(\mathrm{a}_{2}\right)$ & $0.165\left(\mathrm{a}_{3}\right)$ \\
\hline Saturation Coefficient $(\mathrm{m})$ & & $1.0\left(\mathrm{~m}_{2}\right)$ & $1.0\left(\mathrm{~m}_{3}\right)$ \\
\hline
\end{tabular}

In Figure 5.10, structural number layers are observed in reference to the surface (pavement) course $\left(\mathrm{SN}_{1}\right)$, base course $\left(\mathrm{SN}_{2}\right)$, and subbase course $\left(\mathrm{SN}_{3}\right)$.

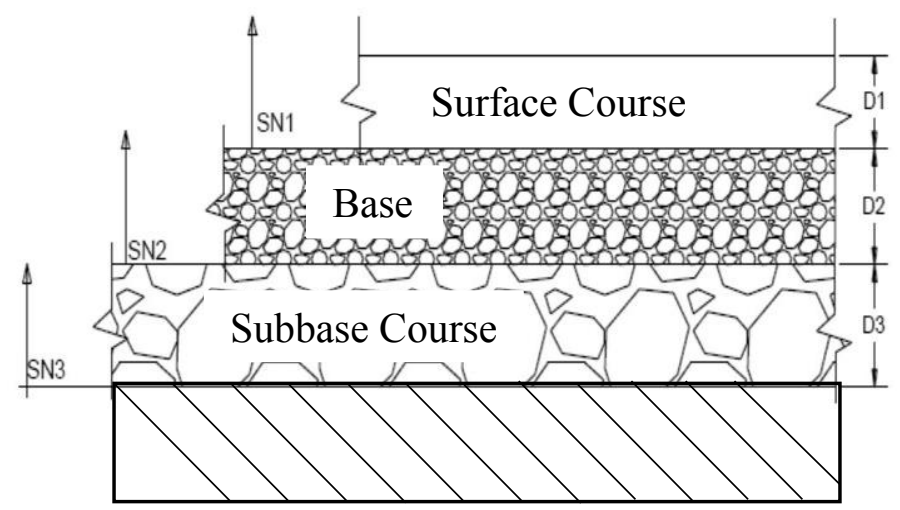

Figure 5. 10 Cross section of structural number $(\mathrm{SN})$ layers and depths in a pavement system (Setegn, 2012)

Now subtracting out the volume of TDGCs:

Where:

$\mathrm{h}=$ average thickness, or height of a TDGC (=8.5 inch), conservative value for calculation. $\mathrm{r}=$ radius of TDGC (outer radius is approx. $12 \mathrm{inch}$ and inner radius is approx. $11 \mathrm{inch}$ )

\section{Outer dimension:}

$$
\begin{gathered}
\text { Volume }_{T D G C, \text { out }}=\pi \times r^{2} \times h \\
\text { Volume }_{T D G C, \text { out }}=\pi \times 12 \text { inch }^{2} \times 8.5=3845.31 \mathrm{in}^{3}
\end{gathered}
$$

Converting to cubic yardage: Volume for outer dimension is $\mathbf{0 . 0 8 2 4} \mathbf{C Y}$ 


\section{Inner dimension:}

$$
\begin{gathered}
\text { Volume }_{T D G C, \text { in }}=\pi x r^{2} \times h \\
\text { Volume }_{T D G C, \text { in }}=\pi \times 11 \text { inch }^{2} \times 8.5=3231.13 \mathrm{in}^{3}
\end{gathered}
$$

Converting to cubic yardage: Volume for outer dimension is $\mathbf{0 . 0 6 9 2 5 ~ C Y ~}$

Estimate the number of TDGCs where 0.20 factor was obtained from industry for a 1-mile road with two-12 ft. lanes each with a $2 \mathrm{ft}$. shoulder:

Number of TDGCs $=($ length $x$ width $) \times$ conversion factor $=$ $(5,280 \mathrm{ft} . \times 28 \mathrm{ft}$. $) \times 0.20=29,568 \mathrm{TDGCs}$

If approximately a $24 \mathrm{in.} \mathrm{TDGC} \mathrm{is} \mathrm{used,} \mathrm{nearly} \mathrm{29,568} \mathrm{TDGCs} \mathrm{will} \mathrm{fit} \mathrm{in} \mathrm{a} \mathrm{road} \mathrm{that} \mathrm{is}$ dimensions of 5,280 feet ( 1 mile) long by 28 feet in wide.

$$
\begin{gathered}
\Delta \text { Volume }_{T D G C}=\text { Volume }_{T D G C, \text { out }}-\text { Volume }_{T D G C, \text { in }} \\
\Delta \text { Volume }_{T D G C}=0.0824 \mathrm{CY}-0.06925 \mathrm{CY}=0.0132 \mathrm{CY} \text { per TDGC }
\end{gathered}
$$

$\therefore$ Estimated volume reduction due to TDGC installallation

$$
=\text { Number of TDGCs } x \Delta \text { Volume }_{T D C}
$$

Estimated volume reduction $(T D G C$ installation $)=29,568 T D C s \times 0.0132 C Y$ per TDGC $\approx 390$ CY of aggregate loss

Overall, the amount of aggregate used for a road dimensioned at 5,280 feet ( 1 mile) by 28 feet (two-12 ft. lanes each with a $2 \mathrm{ft}$. shoulder) with TDGC reinforcement:

$$
\begin{gathered}
\text { Volume }_{\text {tot,rein }}=\text { Volume }_{\text {aggr, }, \text { ein }}-\text { Estimated volume reduction to TDGC Installation } \\
\text { Volume }_{\text {tot,rein }}=4,111 \mathrm{CY}-390 \mathrm{CY}=\mathbf{3 , 7 2 1} \mathbf{C Y}
\end{gathered}
$$

\section{Reduction of Material:}

$$
\begin{aligned}
& \text { Aggregate: } \Delta \text { Volume }=\text { Volume }_{\text {agg,hma no }}-\text { Volume }_{\text {agg,hma rein }} \\
& =3,742 C Y-3,721 C Y=\mathbf{2 1} C Y \\
& \text { HMA: } \Delta \text { Volume }=\text { Volume }_{H M A, n o}-\text { Volume }_{H M A, \text { rein }}=
\end{aligned}
$$

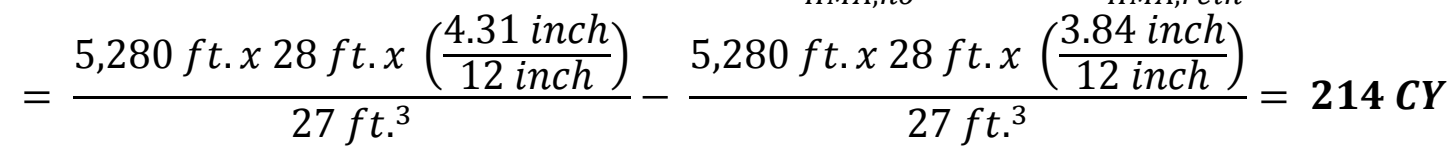




\section{Conclusions}

By taking the difference of the volume of unreinforced volume to volume obtained for TDGC reinforced volume, a reduction of approximately $21.0 \mathrm{CY}$ of aggregate and $214 \mathrm{CY}$ of asphalt material are obtained with the TDGC reinforced HMA system. The depth for installation should be considered to be 9 inches due to $~ 8$-inch thickness of the TDGC. This thickness suggestion is based on the values and assumptions previously discussed the AASHTO suggested requirements. The SNs for a non-TDGC HMA pavement system were calculated to be 1.86 and 3.10 for the base and subbase (Table 5.1). SNs for a TDGC reinforced HMA system were calculated to be 1.44 and 3.20 for base and subbase (Table 5.2). All potential construction applications with TDGCs should comply with the suggested installation standards for Roadway Base or Shoulders, Gravity Retaining Walls or Mechanically Stabilized Earth (MSE) Walls, Load Bearing Walls, Abutments, or Load Bearing Pier Foundation as per manufacturer recommended specifications along with those of the regulatory agencies. It is also suggested to comply with the standard WVDOH specs pertaining to compaction of subgrade, geotextile installation, and roadway construction, shall be complied. A detailed cost analysis including construction activity schedule are provided for flexible (HMA) pavement in Section 5.3. However, such construction activity schedule is not available for rigid (PCC) pavements. Hence the only cost comparison is for material usage with and without TDGC reinforcement are shown for the design example for rigid pavements in Section 5.2.2. 


\subsubsection{Proposed Rigid Pavement Design Example}

\section{List of Abbreviations and Key Labels}

$\mathrm{D}_{\mathrm{SB}}=$ subbase thickness (in.)

$\mathrm{M}_{\mathrm{R}}=$ roadbed soil resilient modulus (lb/in. ${ }^{2}$ )

$\mathrm{E}_{\mathrm{SB}}=$ subbase elastic modulus (lb/in. $\left.{ }^{2}\right)$

$\mathrm{k}_{\infty}=$ composite modulus of subgrade (lb/in. $\left.{ }^{3}\right)$

$\mathrm{k}=$ effective modulus of subgrade reaction (lb/in. $\left.{ }^{3}\right)$

$\mathrm{LS}=$ loss of support

$\mathrm{Z}_{\mathrm{R}}=$ standard normal variant corresponding to reliability

$\mathrm{S}_{\mathrm{o}}=$ overall standard deviation

$\mathrm{W}_{18}=$ predicted number of 18 kip equivalent single axle loads (ESALS) applications that can be carried by the pavement structure after construction

$\mathrm{D}=$ thickness of concrete pavement to the nearest half inch (in.)

$\Delta \mathrm{PSI}=$ design serviceability loss $=\mathrm{P}_{\mathrm{i}}-\mathrm{P}_{\mathrm{t}}$

$\mathrm{P}_{\mathrm{i}}=$ initial serviceability index

$\mathrm{P}_{\mathrm{t}}=$ terminal serviceability index

$\mathrm{E}_{\mathrm{c}}=$ elastic modulus of the concrete to be used in construction (lb/in. $\left.{ }^{2}\right)$

$\mathrm{S}_{\mathrm{c}}{ }^{\prime}=$ modulus of rupture for concrete used in construction (lb/in. $\left.{ }^{2}\right)$

$\mathrm{J}=$ load transfer coefficient (typical value $=3.2$ )

TDGC $=$ tire derived geo-cylinder

$\mathrm{PCC}=$ Portland Cement Concrete

Volume $_{T D G C, \text { out }}=$ TDGC outer dimensional volume

Volume $_{\text {TDGC,in }}=$ TDGC inner dimensional volume

$\Delta$ Volume $_{T D G C}=$ change in volume form TDGC $\left(\right.$ Volume $_{T D G C, \text { out }}-$ Volume $_{T D G C, \text { in }}$

\section{Units Associated with Calculations:}

ESAL = equivalent single axle load

lb. = pound

psi $=$ pounds per square inch $\left(\mathrm{lb} / \mathrm{in}^{2}\right)$

in. $=$ inch

$\mathrm{ft} .=$ feet

$\mathrm{SF}=\mathrm{ft}^{2}$

$\mathrm{CY}=$ cubic yards

Tons = tonnage

Kip $=1,000$ pounds-force 
Step 1: $\quad$ Calculate the $\mathrm{M}_{\mathrm{R}}$.

Table 5. 3 Calculate the estimated average modulus of resilience throughout a year

\begin{tabular}{|c|c|c|c|}
\hline Month & Period & CBR & $\mathrm{M}_{\mathrm{R}}$ \\
\hline 1 & 1 & 17.6 & 26400 \\
\hline & 2 & 17.6 & 26400 \\
\hline 2 & 1 & 17.6 & 26400 \\
\hline & 2 & 17.6 & 26400 \\
\hline 3 & 1 & 4.4 & 6600 \\
\hline & 2 & 4.4 & 6600 \\
\hline 4 & 1 & 4 & 6000 \\
\hline & 2 & 4 & 6000 \\
\hline 5 & 1 & 4 & 6000 \\
\hline & 2 & 4 & 6000 \\
\hline 6 & 1 & 5.5 & 8250 \\
\hline & 2 & 5.5 & 8250 \\
\hline 7 & 1 & 5.5 & 8250 \\
\hline & 2 & 5.5 & 8250 \\
\hline 8 & 1 & 5.5 & 8250 \\
\hline & 2 & 5.5 & 8250 \\
\hline 9 & 1 & 6.8 & 10200 \\
\hline & 2 & 6.8 & 10200 \\
\hline 10 & 1 & 6.8 & 10200 \\
\hline & 2 & 6.8 & 10200 \\
\hline 11 & 1 & 4.8 & 7200 \\
\hline & 2 & 4.8 & 7200 \\
\hline 12 & 1 & 17.6 & 26400 \\
\hline & 2 & 17.6 & 26400 \\
\hline & & & \\
\hline
\end{tabular}

\{Averaging the $\mathrm{M}_{\mathrm{R}}$, it is found to equal 8,400 lb/in. ${ }^{2}$ (pg. II-38 AASHTO Road Test, 1993)\}

Step 2: $\quad$ Calculate the $\mathrm{E}_{\mathrm{SB}}$

From the 1993 AASHTO Flexible Pavement Design, a CBR value of 65 provides a subbase modulus near $27,700 \mathrm{lb} /$ in. $^{2}$

(pgs. II-19 \& II-21 of AASHTO Road Test, 1993)

Step 3: $\quad$ Determine subbase thickness

In accordance with the American Society of State Highway and Transportation Officials (AASHTO, 1993) and the Federal Highway Administration (FHWA, 2017), the minimum unreinforced thickness is 6 inches. The minimum for a reinforced base is 9 inches due to the average depth (8.5 in.) of a TDGC. 
Knowing the above information, the composite modulus of subgrade reaction $(\mathrm{k} \infty)$ can be obtained for an unreinforced and reinforced TDGC subbase.

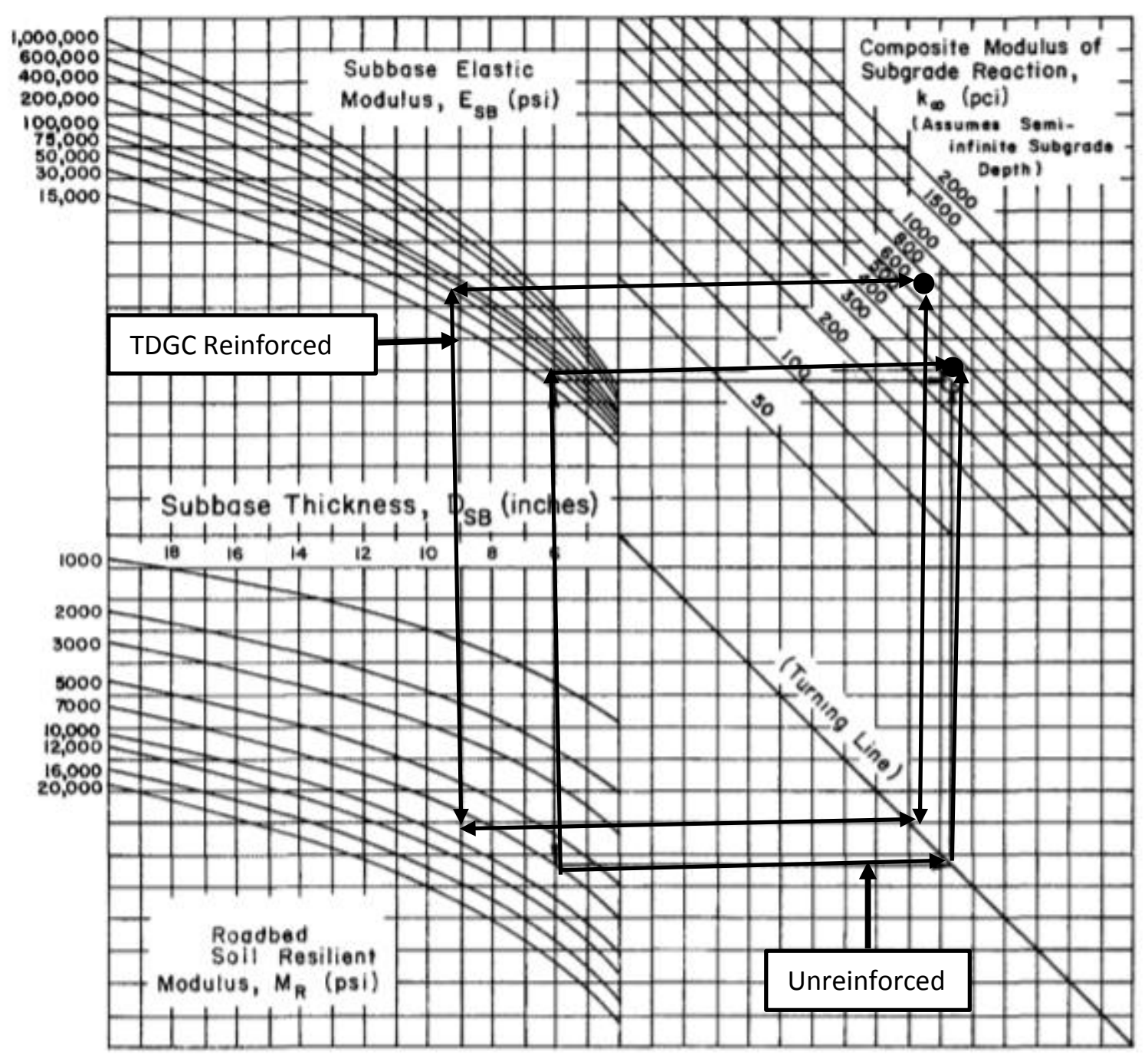

Figure 3.3. Chart for Estimating Composite Modulus of Subgrade Reaction, $\mathbf{k}_{\infty}$, Assuming a Semi-Infinite Subgrade Depth. (For practical purposes, a semi-infinite depth is considered to be greater than 10 feet below the surface of the subgrade.)

Figure 5. 11 Nomograph to determine composite modulus of subgrade reaction $\left(\mathrm{k}_{\infty}\right)$

$$
\begin{gathered}
\mathrm{k}_{\infty}=450 \mathrm{lb} / \mathrm{in}^{3}{ }^{3} \text { (unreinforced) } \\
\mathrm{k}_{\infty}=700 \mathrm{lb} / \mathrm{in}^{3}{ }^{3} \text { (proposed value with TDGC reinforcement) }
\end{gathered}
$$


Step 4: $\quad$ Determine the effective modulus of subgrade reaction taking into consideration loss of support (LS).

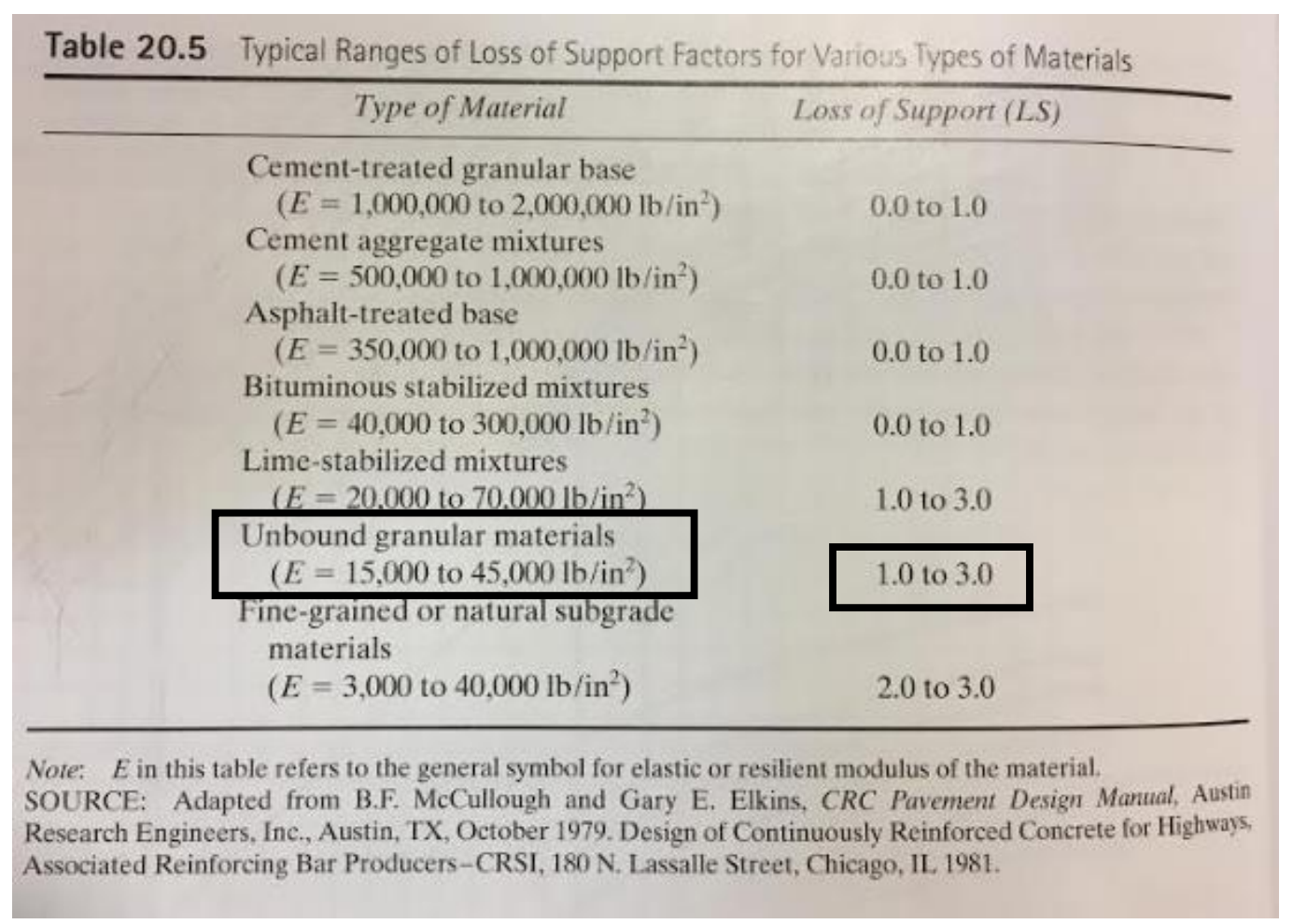

Figure 5. 12 Loss of support values for materials in pavement design

Since the subbase elastic modulus is 27,700 for unreinforced $\left(\mathrm{lb} / \mathrm{in}^{2}\right)$ and $37,118\left(\mathrm{lb} / \mathrm{in}^{2}\right)$ with respect to a $34 \%$ increase or the unreinforced value, the range for unbounded granular materials was selected for analysis. Calculations were performed with $\mathrm{LS}=1.0$.

\{Next, apply the LS of 1.0 to the $\mathrm{k}_{\infty}$ values (Figure 5.13) for unreinforced and reinforced bases.\} 


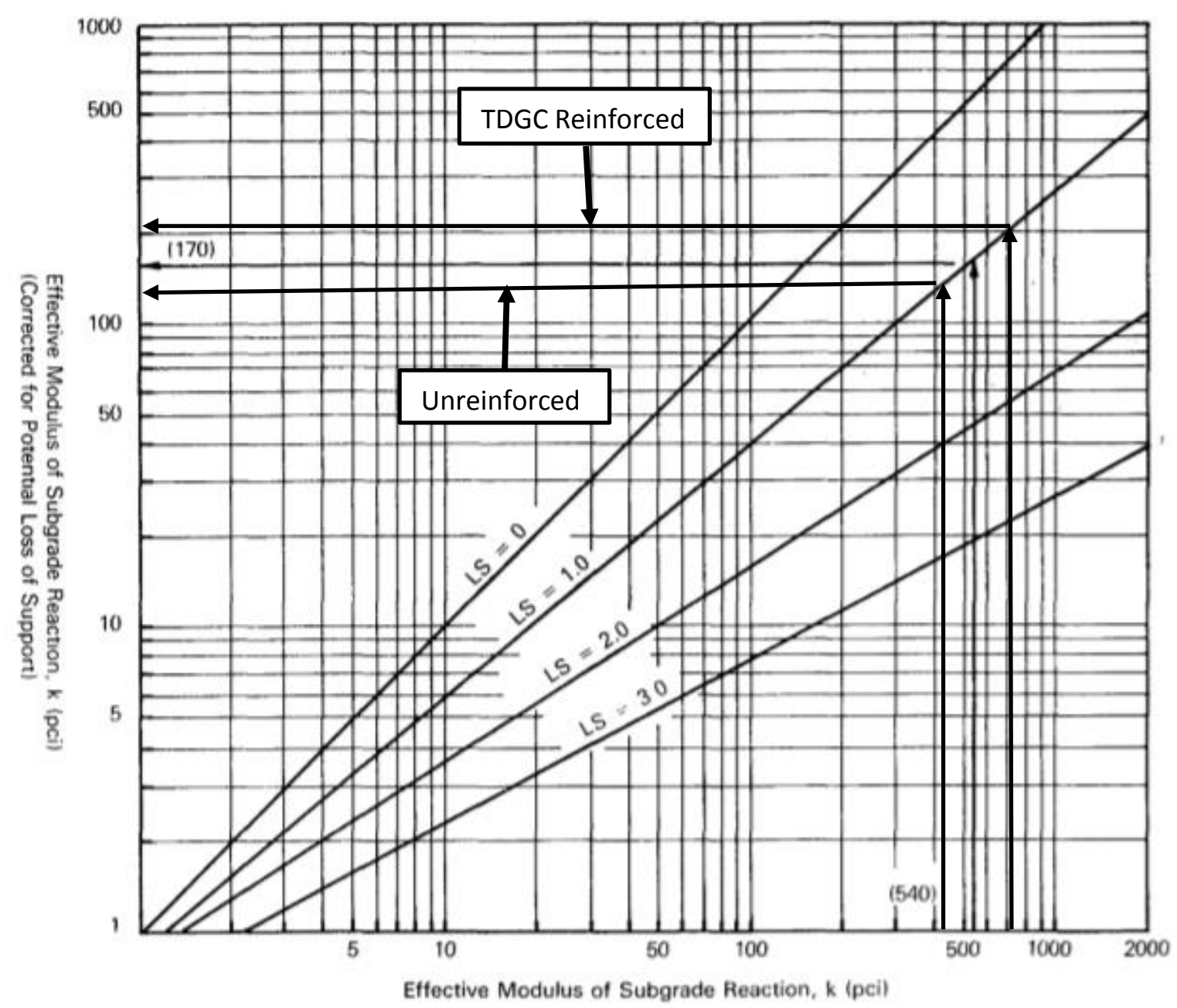

Figure 3.6. Correction of Effective Modulus of Subgrade Reaction for Potential Loss of Subbase Support (6)

Figure 5. 13 Application of LS to solve for the effective modulus of subgrade reaction (k)

The correction of modulus of subgrade reaction is as follows:

$$
\begin{aligned}
& \mathrm{k}_{\infty}=450 \text { then after LS is applied, } \mathrm{k}=130 \mathrm{lb} / \mathrm{in}^{3} \\
& \mathrm{k}_{\infty}=700 \text { then after LS is applied, } \mathrm{k}=210 \mathrm{lb} / \mathrm{in}^{3}
\end{aligned}
$$


Step 5: $\quad$ Reliability, $\mathrm{R}=90 \%$

Standard Normal Variate, $\mathrm{Z}_{\mathrm{R}}=-1.282$

\begin{tabular}{cc} 
Table 4.1. & $\begin{array}{l}\text { Standard Normal Deviate }\left(\mathbf{Z}_{\mathbf{k}}\right) \text { Values } \\
\text { Corresponding to Selected Levels of } \\
\text { Reliability }\end{array}$ \\
\hline $\begin{array}{c}\text { Reliability, } \\
\text { R (percent) }\end{array}$ & $\begin{array}{c}\text { Standard Normal } \\
\text { Deviate, } \mathbf{Z}_{\mathbf{R}}\end{array}$ \\
\hline 50 & -0000 \\
60 & -0253 \\
70 & -0524 \\
75 & -0674 \\
80 & -0841 \\
85 & -1037 \\
90 & -1282 \\
91 & -1340 \\
92 & -1405 \\
93 & -1476 \\
94 & -1555 \\
95 & -1645 \\
96 & -1751 \\
97 & -1881 \\
98 & -2054 \\
99 & -2327 \\
99 & -3090 \\
99 & -3950 \\
\hline
\end{tabular}

Figure 5. 14 Standard normal variant for rigid pavement design

Step 6: $\quad$ Standard deviation, $S_{o}=0.40$

Standard Deviation, $S_{0}$

\begin{tabular}{|lc|}
\hline Flexible pavements & $0.40-0.50$ \\
\hline Rigid pavements & $0.30-0.40$ \\
\hline
\end{tabular}

These values were derived through a detailed analysis of existing data. However, very little data currently exists for certain design components, such as drainage. A methodology for improving these estimates is presented in the 1993 AASHTO guide which may be used when additional data are available.

Figure 5. 15 Standard deviation for rigid pavement

Step 7: $\quad$ Design for serviceability loss, $\triangle \mathrm{PSI}=\mathrm{P}_{\mathrm{i}}-\mathrm{P}_{\mathrm{t}}$

$\mathrm{P}_{\mathrm{i}}=4.5$ and $\mathrm{P}_{\mathrm{t}}=2.5$.

Therefore, $\Delta \mathrm{PSI}=2.0($ pg. 1102 Garber and Hoel, 2009)

Step 8: $\quad$ Elastic modulus of the concrete in construction, $\mathrm{E}_{\mathrm{c}}=4,000,000 \mathrm{psi}$ (Pavement Interactive, 2012) 
Step 9: $\quad$ Determine the mean modulus of rupture $\left(\mathrm{S}_{\mathrm{c}}{ }^{\prime}\right)$

To provide a conservative design, a $\mathrm{S}_{\mathrm{c}}{ }^{\prime}=500 \mathrm{psi}$ was used as it is the minimum mean modulus of rupture present in the 1993 AASHTO Road Design nomographs. (pg. II- 45 AASHTO Road Test, 1993)

Step 10: $\quad$ Load transfer coefficient $(\mathrm{J})$ was determined to be the assumed value used in the 1993 AASHTO Road Test. J = 3.2 (Pavement Interactive, 2012)

Step 11: $\quad$ Drainage coefficient determination $\left(\mathrm{C}_{\mathrm{d}}\right)$

Table 20.9 Recommended Values for Drainage Coefficient, $C_{d \phi}$ for Rigid Pavements

\begin{tabular}{lcccc}
\hline & \multicolumn{3}{c}{$\begin{array}{c}\text { Percent of Time Pavement Structure is Exposed } \\
\text { to Moisture Levels Approaching Saturation }\end{array}$} \\
\cline { 2 - 5 } $\begin{array}{l}\text { Quality of } \\
\text { Drainage }\end{array}$ & Less Than 1\% & $1-5 \%$ & $5-25 \%$ & $\begin{array}{c}\text { Greater Than } \\
25 \%\end{array}$ \\
\hline Excellent & $1.2-1.20$ & $1.20-1.15$ & $1.15-1.10$ & 1.10 \\
Good & $1.20-1.15$ & $1.15-1.10$ & $1.10-100$ & 1.00 \\
Fair & $1.15-1.10$ & $1.10-1.00$ & $1.00-0.90$ & 0.90 \\
Poor & $1.10-1.00$ & $1.00-0.90$ & $0.90-0.80$ & 0.80 \\
Very poor & $1.00-0.90$ & $0.90-0.80$ & $0.80-0.70$ & 0.70 \\
\hline SOURCE: Adapted from AASHTO Guide for Design of Pavement Structures, American Association of State Highway and \\
Transportation Officials, Washington, D.C., 1993. Used with permission.
\end{tabular}

Figure 5. 16 Moisture exposure on rigid pavement structures

\{Assuming fair drainage conditions and moderate rainfall, $\mathrm{C}_{\mathrm{d}}$ is chosen to be 1.0 \}

Step 12: $\quad$ Solve Segment 1 and 2 Nomograph (Figure 5.17 and 5.18) with previously calculated values to obtain the Portland Cement Concrete pavement thicknesses for an unreinforced and reinforced base layer. (pg. II-45 AASHTO Road Test, 1993) 


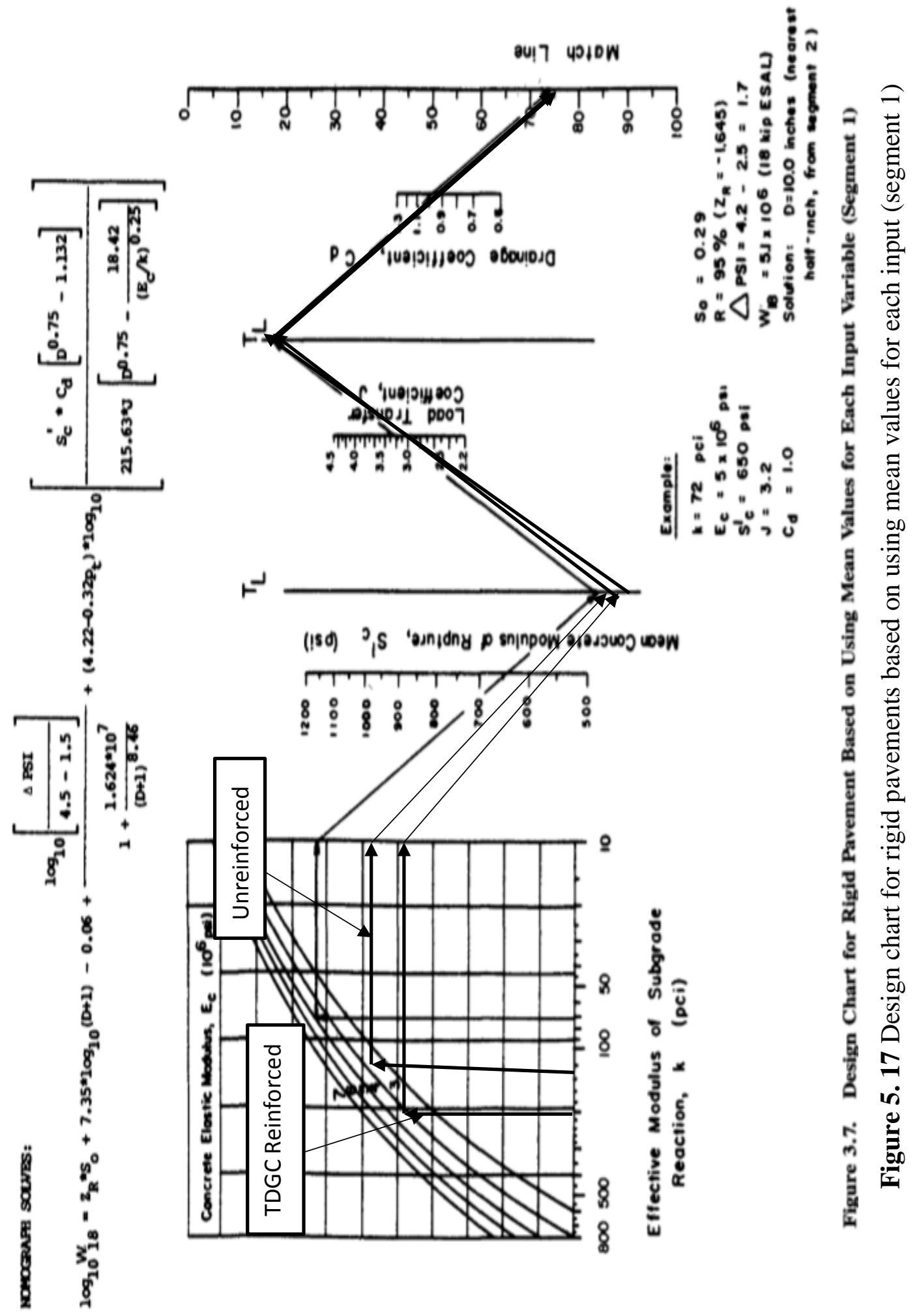




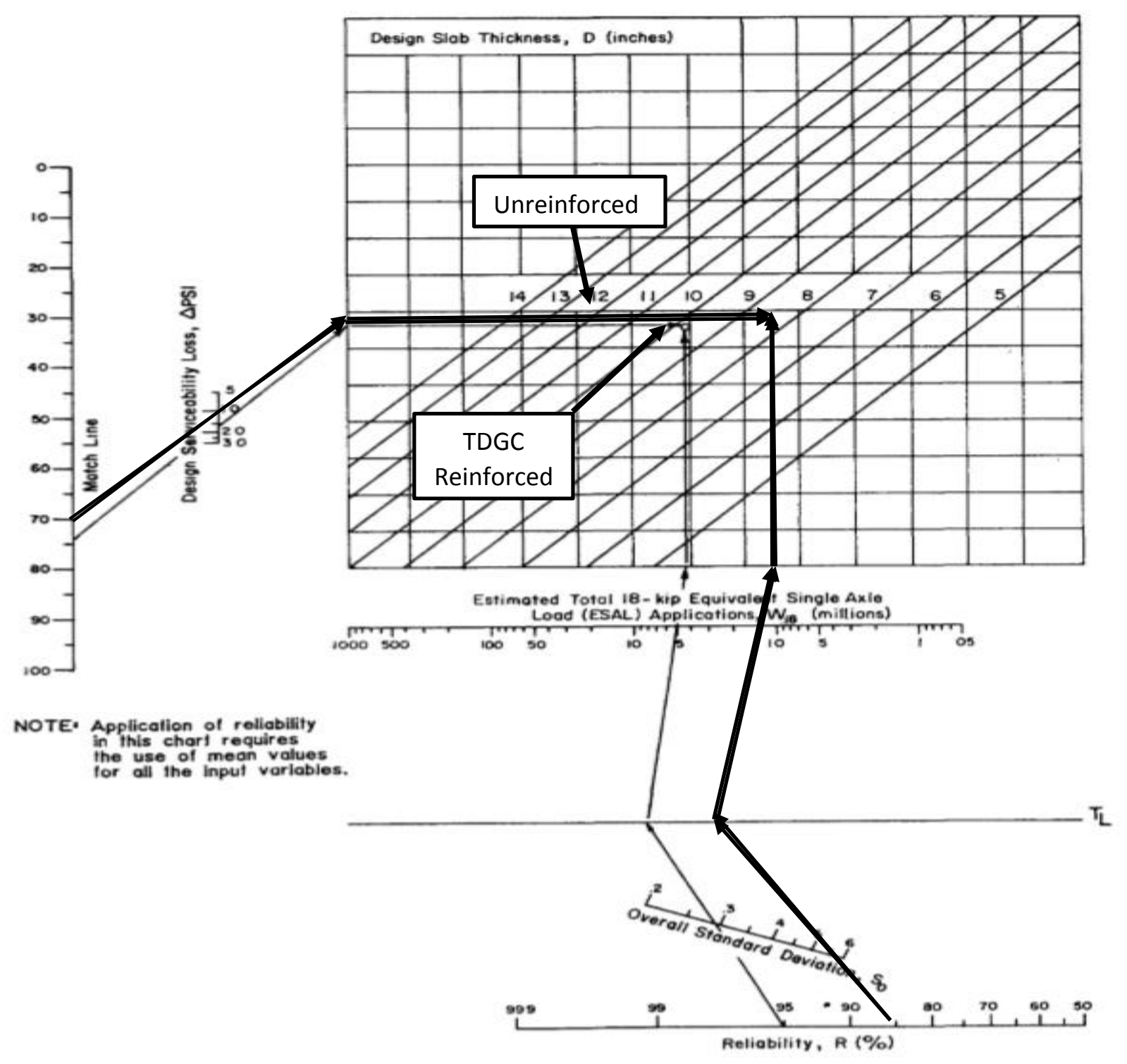

Figure 3.7. Continued-Design Chart for Rigid Pavements Based on Using Mean Values for Each Input Variable (Segment 2)

Figure 5. 18 Design chart for rigid pavements based on using mean values for each input (segment 2) 
(Equation 5.2) Solving the 1993 AASHTO rigid pavement design equation:

$$
\begin{gathered}
\log _{10} W_{18}=Z_{R} * S_{O}+7.35 * \log _{10}(\mathrm{D}+1)-0.06+\frac{\log _{10}\left(\frac{\Delta P S I}{4.5-1.5}\right)}{1+\left[\frac{1.64410^{7} 7}{(D+1)^{8.46}}\right]}+(4.22- \\
\left.0.32 P_{t}\right) \log _{10}\left\{\frac{S_{c^{\prime}} * C_{d}}{215.6 J}\left(\frac{D^{0.75}-1.1 .132}{D^{0.75}-\left[\frac{18.42}{\left.\left(E_{C} / k\right)^{0.25}\right]}\right)}\right)\right\}
\end{gathered}
$$

Solve the above equation for $W_{18}$ for an unreinforced/reinforced subbase by inserting the design slab thicknesses variables needed to obtain the value, respectively.

$$
\begin{aligned}
& Z_{R^{*} S_{O}}+7.35 * \log _{10}(\mathrm{D}+1)-0.06+\frac{\log _{10}\left(\frac{\Delta P S I}{4.5-1.5}\right)}{1+\left[\frac{1.624 * 10^{7}}{(D+1)^{8.46}}\right]}+\left(4.22-0.32 P_{t}\right) \log _{10}\left\{\frac{S_{c^{\prime}} * C_{d}}{215.6 J}\left(\frac{D^{0.75}-1 . .132}{D^{0.75}-\left[\frac{18.42}{\left.\left(E_{C} / k\right)^{0.25}\right]}\right]}\right)\right\} \\
& W_{18}=10
\end{aligned}
$$

Solving in accordance with the above nomograph to obtain the $\mathrm{W}_{18}$ values, the design Portland Cement Concrete slab thickness is calculated to be: $\mathbf{8 . 3}$ inches (unreinforced depth).

Solving in accordance with the above nomograph to obtain the $\mathrm{W}_{18}$ values, the design for Portland Cement Concrete can be obtained. Enhancement of effective modulus of subgrade reaction by $34 \%$ (obtained from laboratory data) can be inserted into the design calculation to increase $170 \mathrm{lb} / \mathrm{in}^{2}{ }^{2}$ to $200 \mathrm{lb} / \mathrm{in}^{2}$. Slab thickness is calculated to be: $\mathbf{8 . 0}$ inches. 


\section{For cost comparison, slab thicknesses were rounded to the nearest "half-inch" to account for constructability. This is noted from the FHWA and 1993 AASHTO Road Test. \\ Cost Analysis Assumptions and Computations for Rigid (PCC) Pavement}

Assumptions used in the cost analysis are:

$>$ Aggregate (\#57's) conversion factor from CY to tons was 1.4 (http://www.plaistedcompanies.com/Calculator.aspx)

$>$ Factor multiplied by the surface area of the road to obtain number of TDGCs is 0.2 (obtained from: Bonasso, Sam)

\#57 aggregate unit price was $\$ 17.50 /$ ton- trucking not included in price (Auburn Aggregates, 2018)

$>$ Portland Cement Concrete unit price was \$153.24/CY (Huynh, 2012)

$>$ Approximate volume per TDGC $=0.0132 \mathrm{CY} / \mathrm{TDGC}$

$>$ The pavement length $=1$ mile

$>$ Number of lanes is 2 a long with a 2 foot shoulder on each side.

1. Unreinforced aggregate calculations for concrete slab (8.5 inches thick) Length $=5,280$ feet $(1$ mile), Width $=28$ feet (two- $12 \mathrm{ft}$. lanes with $2 \mathrm{ft}$. shoulders on each side), Depth $=0.5 \mathrm{ft}$. (6 inches)

volume $=$ length $x$ width $x$ depth $=5,280$ ft. $x 28$ ft. $x 0.5 f t .=73,920 \mathrm{ft}^{3}$

$$
\begin{gathered}
\text { volume }(C Y)=\frac{\text { volume }(f t .)}{27 f t^{3}}=\frac{73,920 \mathrm{ft}^{3}}{27 \mathrm{ft.}^{3}}=2737.78 \mathrm{CY} \\
\text { Aggregate tonnage }=\text { volume }(\mathrm{CY}) \times 1.4=2737.78 \mathrm{CY} * 1.4=3832.89 \text { tons } \\
\operatorname{Cost}(\$)=\frac{\$ 17.50}{\text { ton }} \text { xaggregate tonnage }=\frac{\$ 17.50}{\text { ton }} \times 3832.89 \text { tons }=\$ 67,075.56
\end{gathered}
$$

2. 8.5 inch thick concrete slab calculations Length $=5,280$ feet $(1$ mile), Width $=28$ feet (two- $12 \mathrm{ft}$. lanes with $2 \mathrm{ft}$. shoulders on each side), Depth $=0.71 \mathrm{ft}$. (8.5inches)

volume $=$ length $x$ width $x$ depth $=5,280 \mathrm{ft} . x 28 \mathrm{ft} . x 0.71 \mathrm{ft} .=104,966.40 \mathrm{ft}^{3}$

$$
\begin{gathered}
\text { volume }(C Y)=\frac{\text { volume }(f t .)}{27 f .^{3}}=\frac{104,966.40 f t .^{3}}{27 f t .^{3}}=3,887.64 C Y \\
\operatorname{Cost}(\$)=\frac{\$ 153.24}{\text { ton }} \times \operatorname{PCC}(C Y)=\frac{\$ 153.24}{\text { ton }} \times 3,887.64 C Y=\$ 595,742.63
\end{gathered}
$$


Total Cost of Concrete Slab (8.5 inch thick) and Min. Unreinforced Sub Base (6 inches thick) (\$) $=\$ 67,075.56+\$ 595,742.63=\underline{\$ 662,818.19}$

3. Reinforced aggregate calculations for 9 inch thick TDGC

Length $=5,280$ feet $(1$ mile), Width $=28$ feet (two- $12 \mathrm{ft}$. lanes with $2 \mathrm{ft}$. shoulders on each side), Depth $=0.75 \mathrm{ft}$. (9 inches)

volume $=$ length $x$ width $x$ depth $=5,280 \mathrm{ft} . x 28 \mathrm{ft} . x 0.75 \mathrm{ft} .=110,880 \mathrm{ft}^{3}{ }^{3}$

$$
\begin{gathered}
\text { volume }(C Y)=\frac{\text { volume }(f t .)}{27 f .^{3}}=\frac{110,880 f t^{3}}{27 \mathrm{ft}^{3}}=4,107 \mathrm{CY} \\
\text { Aggregate tonnage }=\operatorname{volume}(\mathrm{CY}) \times 1.4=2737.78 \mathrm{CY} * 1.4=5,749.33 \text { tons } \\
\text { Cost }(\$)=\frac{\$ 17.50}{\text { ton }} \text { xaggregate tonnage }=\frac{\$ 17.50}{\text { ton }} \times 5,749.33 \text { tons }=\$ 100,613.30
\end{gathered}
$$

\section{Outer dimension:}

$$
\begin{gathered}
\text { Volume }_{T D G C, \text { out }}=\pi x r^{2} \times h \\
\text { Volume }_{T D G C, \text { out }}=\pi \times 12 \text { inch }^{2} \times 8.5=3845.31 \text { in }^{3}
\end{gathered}
$$

Converting to cubic yardage: Volume for outer dimension is $\mathbf{0 . 0 8 2 4} \mathbf{C Y}$

\section{Inner dimension:}

$$
\begin{gathered}
\text { Volume }_{T D G C, \text { in }}=\pi x r^{2} \times h \\
\text { Volume }_{T D G C, \text { in }}=\pi x 11 \text { inch }^{2} \times 8.5=3231.13 \text { in }^{3}
\end{gathered}
$$

Converting to cubic yardage: Volume for outer dimension is $\mathbf{0 . 0 6 9 2 5} \mathbf{C Y}$

If approximately a 24 inch TDGC is used, nearly 3,000 TDGCs will fit in a road that has dimensions of 1,000 feet in length by 12 feet in width.

$$
\begin{gathered}
\Delta \text { Volume }_{T D G C}=\text { Volume }_{T D G C, \text { out }}-\text { Volume }_{T D G C, \text { in }} \\
\Delta \text { Volume }_{T D G C}=0.0824 C Y-0.06925 C Y=0.0132 C Y \text { per } T D G C
\end{gathered}
$$


Volume (CY) of TDGCs for a road dimensioned at $5,280 \mathrm{ft}$. $\times 28 \mathrm{ft}$. width (includes shoulder).

Conversion factor to estimate the number of tires corresponding to the surface area $=0.20$

$$
\begin{gathered}
\text { Number of TDGCs }=(\text { length } \times \text { width }) \times \text { conversion factor }= \\
(5,280 \mathrm{ft} . \times 28 \mathrm{ft} .) \times 0.20=29,568 \mathrm{TDGCs}
\end{gathered}
$$

$$
\text { volume } \begin{aligned}
(C Y) & =\text { number of TDGCs } x 0.0132 \frac{C Y}{T D G C}=29,568 T D G C \times 0.0132 \frac{C Y}{T D G C} \\
& =390.30 \mathrm{CY}
\end{aligned}
$$

Convert volume $(\mathrm{CY})$ to tons: volume $(C Y) \times 1.4=390.3 C Y \times 1.4=546.4$ tons

Cost $(\$)=\frac{\$ 17.50}{\text { ton }} \times$ aggregate tonnage $=\frac{\$ 17.50}{\text { ton }} \times 546.42$ tons $=\$ 9,562.35$

Total Cost with TDGC volume subtracted out $=\$ 100,613.28-\$ 9,562=\$ 91,051.28$

4. 8 inch thick concrete slab (Rigid Pavement) calculation for TDGC

Length $=5,280$ feet $(1$ mile), Width $=28$ feet (two- $12 \mathrm{ft}$. lanes with $2 \mathrm{ft}$. shoulders on each side), Depth $=0.67 \mathrm{ft}$. $(8$ inches $)$

volume $=$ length $x$ width $x$ depth $=5,280 \mathrm{ft} . x 28 \mathrm{ft} . x 0.67 \mathrm{ft} .=98,560 \mathrm{ft}^{3}{ }^{3}$

$$
\begin{gathered}
\text { volume }(C Y)=\frac{\text { volume }(f t .)}{27 f t .^{3}}=\frac{98,560 f t^{3}}{27 f t .^{3}}=3,650.37 C Y \\
\operatorname{Cost}(\$)=\frac{\$ 153.24}{\text { ton }} x \operatorname{PCC}(C Y)=\frac{\$ 153.24}{\text { ton }} \times 3,650.37 C Y=\$ 559,382.76
\end{gathered}
$$

Total Cost (\$) of Concrete Slab (8 inches thick) and TDGC reinforced sub base (9 inches)

Total Cost $(\$)=\$ 91,051.28+\$ 559,382.76=\underline{\$ 650,434.04}$

Total Cost Savings with the Use of TDGC for Rigid Pavements (PCC Roadway Slab)

Total Cost Saving $(\$)=$ Unreinforced Price $(\$)-$ Reinforced TDGC Price $(\$)$

$$
=\$ 662,818.19-\$ 650,434.04=\$ \mathbf{1 2}, \mathbf{3 8 4} .15
$$

In summary, considering a best case reduction of 3 inches of aggregate by using the allowable 6 inch thickness for an unreinforced base (FWHA, 2017); a reduction of 0.5 inches in PCC slab thickness is observed due to the $34 \%$ increase of the sub base elastic modulus $\left(\mathrm{E}_{\mathrm{SB}}\right)$ as per the 1993 Rigid Pavement Nomograph. The unit price for concrete is higher than that of the 
AASHTO \#57 aggregate. Analysis suggests that less PCC material is needed for a reinforced base with the reinforced TDGC which results in overall cost savings.

\subsection{Cost Analysis for Conventional and Mechanical Concrete HMA Roadway Construction}

This section examines the construction costs associated with developing a hot-mix asphalt (HMA) road system with and without TDGC installation as base/sub base reinforcement. This cost analysis incorporates activity time durations based on the activity schedule presented in the work by Chakrey and Pawar (2015). and the Indian Road Council (IRC) (Table 5.4). Calculated costs are not associated to a specific activity, but they are associated with unit rates for equipment, labor, and materials. Equipment, labor, and basic construction material costs were estimated based on the designated activities as per Chakrey and Pawar (2015). The cost analyses calculation used for pavement (roadway) construction with TDGC utilizes the same construction activities as listed by Chakrey and Pawar (2015) related to the use of mechanical concrete road (MCR) similar to the proposed feasible pavement design with TDGC in this section. However, time durations have been slightly altered to reflect construction feasibility in West Virginia. Equipment and labor costs were estimated based on industry norms, Bluebook values, and the Bureau of Labor and Statistics. Equipment idle costs were neglected for analysis. Materials were estimated by applying the calculated volume and surface area for a road dimensioned at: $5,280 \mathrm{ft}$ x $28 \mathrm{ft}$ x Depth of Material ( 8.20 and 9.01 for aggregate; 4.31 and 3.84 for hot-mix asphalt). The material costs were projected utilizing the average rates provided on the West Virginia Department of Transportation (WVDOT) average unit bid prices and industry norms. This cost analysis does not take into consideration production rates; however, trucking rates have been incorporated into the materials needed for the calculated estimate. This cost analysis aims to provide an understanding regarding the potential cost savings from the installation of TDGCs as a reinforcement mechanism for pavement systems.

\section{Units Associated with Calculations:}

hrs $=$ hours

Ton $=$ tonnage

SY $=$ yards squared, or $\mathrm{yd}^{2}$

$\mathrm{CY}=$ cubic yards, $\mathrm{yd}^{3}$ 
Table 5. 4 Activity sheet for time comparison in construction of Mechanical Concrete Road (MCR) and conventional road (in hrs.)

\begin{tabular}{|c|c|c|c|c|c|c|c|}
\hline \multicolumn{4}{|c|}{ Conventional Road } & \multicolumn{4}{|c|}{ Mechanical Concrete Road (MCR) } \\
\hline Item & $\begin{array}{c}\text { Activity } \\
\text { Description }\end{array}$ & $\begin{array}{l}\text { Time } \\
\text { (hrs.) }\end{array}$ & $\begin{array}{l}\text { Cumulative } \\
\text { Time (hrs.) }\end{array}$ & Item & $\begin{array}{c}\text { Activity } \\
\text { Description }\end{array}$ & $\begin{array}{l}\text { Time } \\
\text { (hrs.) }\end{array}$ & $\begin{array}{l}\text { Cumulative } \\
\text { Time (hrs.) }\end{array}$ \\
\hline 1 & $\begin{array}{c}\text { Forming } \\
\text { alignment using } \\
\text { Total Station }\end{array}$ & 1 & 1 & 1 & $\begin{array}{c}\text { Forming } \\
\text { alignment using } \\
\text { Total Station }\end{array}$ & 1 & 1 \\
\hline 2 & $\begin{array}{l}\text { Marking various } \\
\text { lengths on road }\end{array}$ & 1.5 & 2.5 & 2 & $\begin{array}{l}\text { Marking various } \\
\text { lengths on road }\end{array}$ & 1.5 & 2.5 \\
\hline 3 & $\begin{array}{l}\text { Excavation of road } \\
\text { to required grade }\end{array}$ & 15 & 17.5 & 3 & $\begin{array}{c}\text { Excavation of } \\
\text { road to required } \\
\text { grade }\end{array}$ & 12 & 17.5 \\
\hline 4 & $\begin{array}{l}\text { Compaction of } \\
\text { subgrade }\end{array}$ & 2 & 19.5 & 4 & $\begin{array}{l}\text { Compaction of } \\
\text { subgrade }\end{array}$ & 0 & 17.5 \\
\hline 5 & $\begin{array}{l}\text { Laying of sub base } \\
\text { with compaction }\end{array}$ & 6 & 25.5 & 5 & Laying of tires & 4 & 21.5 \\
\hline 6 & $\begin{array}{l}\text { Laying of base } \\
\text { with compaction }\end{array}$ & 5 & 30.5 & 6 & Rivet Tires & 4 & 25.5 \\
\hline 7 & $\begin{array}{l}\text { Laying of water } \\
\text { bound macadam }\end{array}$ & 8 & 38.5 & 7 & $\begin{array}{l}\text { Laying of filler } \\
\text { material in tires }\end{array}$ & 6 & 31.5 \\
\hline 8 & Hold & 24 & 62.5 & 8 & $\begin{array}{c}\text { Laying of prime } \\
\text { coat }\end{array}$ & 3 & 34.5 \\
\hline 9 & $\begin{array}{l}\text { Laying of prime } \\
\text { coat }\end{array}$ & 3 & 65.5 & 9 & $\begin{array}{c}\text { Laying of } \\
\text { bituminous mix }\end{array}$ & 4 & 38.5 \\
\hline 10 & $\begin{array}{c}\text { Laying of } \\
\text { bituminous mix }\end{array}$ & 4 & 69.5 & 10 & $\begin{array}{c}\text { Compaction of } \\
\text { top surface using } \\
\text { a roller }\end{array}$ & 5 & 43.5 \\
\hline 11 & $\begin{array}{l}\text { Compaction of top } \\
\text { surface using a } \\
\text { roller }\end{array}$ & 5 & 75.5 & 11 & Ready for use & 0.5 & 44 \\
\hline 12 & Ready for use & 24 & 98.5 & - & - & - & - \\
\hline
\end{tabular}

Note 1: The time for each activity in this table corresponds to the actual field data by Chakrey and Pawar (2015) with the conventional road system and the road system with recycled tires (MCR).

Note 2: A refined critical path method (CPM) for the proposed design example may further help optimize costs.

The first series of cost analysis focuses on the prices associated with equipment, labor, and materials in conjunction with a non-TDGC reinforced roadway following the provided construction activity sequence. The analysis is as follows: 


\section{Estimated Non-TDGC Reinforced HMA Construction Costs}

General equipment costs have been provided via Bluebook. Hours associated to the equipment have been allotted based on engineering judgement and practical construction norms (Table 5.5). The CAT 330 excavator will perform excavation until it reaches the proposed limits of the roadway. The excavator will also be utilized to place aggregate backfill for the base/sub base. As per section 5.2, uniformity of the aggregate type is assumed throughout the base/ sub base International haul trucks will aid in brining material to and from the site. The trucks will be utilized once the crew begins paving. The CAT 242D skid steer is estimated to be a mobile piece of equipment utilized in various working capacities during construction. The CAT vibratory roller will be utilized for subgrade and aggregate embankment compaction. The roller will also follow then paver once that operation begins. The CAT 14M3 grader will aid obtaining final grade for the roadway system with the utilization of a Trimble GPS system. A CAT model CT13 truck or similar piece of equipment will provide the tack coat for the roadway system. Various other equipment is listed below such as $3 / 4$ ton pick-up trucks, 389 Peterbilt truck tractor with a gooseneck trailer, and a mechanics truck.

Table 5. 5 Equipment costs associated with a non-TDGC reinforced HMA roadway

\begin{tabular}{|c|c|c|c|c|c|c|c|}
\hline Type & Quantity & Item & \multicolumn{2}{|c|}{ Rate $(\$ / \mathbf{h r})$} & Hours & \multicolumn{2}{|r|}{ Cost } \\
\hline CAT 330 & 1 & Excavator & $\$$ & 62.76 & 34 & $\$$ & $2,133.84$ \\
\hline International HX & 2 & On-Road Trucks & $\$$ & 71.03 & 38 & $\$$ & $5,398.28$ \\
\hline CAT 242D & 1 & Skid steer & $\$$ & 16.09 & 10 & $\$$ & 160.90 \\
\hline $\begin{array}{l}\text { CAT CB54B Tandem } \\
\text { Vibratory Roller }\end{array}$ & 1 & Roller & $\$$ & 48.35 & 62 & $\$$ & $2,997.70$ \\
\hline CAT AP600F & 1 & Paver & $\$$ & 231.67 & 18 & $\$$ & $4,170.10$ \\
\hline Ford & 2 & $\begin{array}{l}\text { Company Trucks ( } 3 / 4 \\
\text { Tons Pick-up Trucks) }\end{array}$ & $\$$ & 13.40 & 49 & $\$$ & $1,313.20$ \\
\hline CAT D6N & 1 & Mid-size Dozer & $\$$ & 85.26 & 44 & $\$$ & $3,751.44$ \\
\hline Trimble & 1 & $\begin{array}{l}\text { GPS for Equipment (1 } \\
\text { Dozer and Grader) }\end{array}$ & & 000.00 & - & $\$$ & $2,000.00$ \\
\hline 389 Peterbilt & 1 & Truck Tractor & $\$$ & 56.79 & 8 & $\$$ & 454.32 \\
\hline $\begin{array}{c}\text { Gooseneck Air Ride } \\
\text { Trailer }\end{array}$ & 1 & $\begin{array}{c}\text { Haul Trailer for Truck } \\
\text { Tractor }(10 \text { Ton< })\end{array}$ & $\$$ & 21.68 & 8 & $\$$ & 173.44 \\
\hline CAT CT13 Model & 1 & Mechanic Truck & $\$$ & 56.79 & 73.5 & $\$$ & $4,174.07$ \\
\hline CAT CT13 Model & 1 & $\begin{array}{c}\text { Tack Coat Applier } \\
\text { Truck } \\
\end{array}$ & $\$$ & 56.79 & 3 & $\$$ & 170.37 \\
\hline CAT $14 \mathrm{M} 3$ & 1 & Grader & $\$$ & 67.50 & 10 & $\$$ & 675.00 \\
\hline & & & & & TOTALS & & $27,572.65$ \\
\hline
\end{tabular}


Estimated labor costs are displayed in Table 5.6 (5\% per Diem is factored into the rates for engineers, the inspector, and the superintendent):

Table 5. 6 Labor costs for a non-TDGC reinforced HMA roadway

\begin{tabular}{|c|c|c|c|c|c|c|}
\hline Quantity & Item & \multicolumn{2}{|c|}{ Rate $(\$ / h r)$} & Hours Worked & \multicolumn{2}{|c|}{ Cost } \\
\hline 2 & Surveyors & $\$$ & 31.84 & 2.5 & $\$$ & 159.18 \\
\hline 4 & Laborers (includes Foreman) & $\$$ & 20.07 & 98.5 & $\$$ & $7,907.58$ \\
\hline 1 & Superintendent & $\$$ & 38.38 & 98.5 & $\$$ & $3,780.18$ \\
\hline 4 & Operators & $\$$ & 22.15 & 98.5 & $\$$ & $8,727.10$ \\
\hline 1 & Inspectors & $\$$ & 38.38 & 98.5 & $\$$ & $3,780.18$ \\
\hline 1 & Engineers & $\$$ & 38.38 & 98.5 & $\$$ & $3,780.18$ \\
\hline 1 & Diesel Mechanic/Lubricator & $\$$ & 25.58 & 98.5 & $\$$ & $2,519.80$ \\
\hline & & & & Total & & $0,654.21$ \\
\hline
\end{tabular}

Note: Refer to cumulative construction time (98.5 hours) in Table 5.4.

Estimated materials reflect typical HMA application with appropriate means of geotextile placement for separation purposes between the subgrade and base/sub base layers. Material rates reflect values obtained from the WVDOT average unit bid prices and from construction professionals.

Table 5. 7 Material costs for a non-TDGC reinforced HMA roadway

\begin{tabular}{|c|c|c|c|c|c|c|c|}
\hline Item & $\mathrm{CY}$ & Ton & SY & \multicolumn{2}{|c|}{ Rate } & \multicolumn{2}{|r|}{ Cost } \\
\hline $\begin{array}{l}\text { HMA Without Reinforcement } \\
\text { (\$/Ton), depth of } 4.5 \text { " from } \\
\text { Section } 5.2\end{array}$ & $1,967.00$ & $3,934.00$ & & $\$$ & 80.00 & $\$$ & $314,720.00$ \\
\hline $\begin{array}{l}\text { Aggregate (AASHTO \#57s) } \\
\text { (\$/Ton), depth of } 8.23 " \text { from } \\
\text { Section } 5.2\end{array}$ & $3,742.00$ & $5,238.80$ & & $\$$ & 30.00 & $\$$ & $157,164.00$ \\
\hline $\begin{array}{c}\text { Woven Geotextile Separation } \\
\text { Fabric }(\$ / S Y)\end{array}$ & & & $16,426.67$ & $\$$ & 1.30 & $\$$ & $21,354.67$ \\
\hline $\begin{array}{c}\text { Water Bound Macadam } \\
(\$ / S Y)\end{array}$ & & & $16,426.67$ & $\psi$ & 0.90 & $\$$ & $14,784.00$ \\
\hline & & & & & otal & $\$$ & $508,022.67$ \\
\hline
\end{tabular}

The overall estimated cost of construction for a non-TDGC reinforced HMA roadway utilizing Chakrey and Pawar (2015) activity schedule is the summation of equipment, labor, and material costs. Summation of the estimated cost totals provides a value of $\mathbf{\$ 5 6 6 , 2 4 9 . 5 3}$. 


\section{Estimated TDGC Reinforced HMA Construction Costs}

Equipment will perform the same tasks as previously referred to in the non-TDGC reinforcement section. The only modification is to the hours each piece of equipment is operated. A diminished time duration is observed in Chakrey and Pawar (2015) schedule due to the potential for labor and materials costs associated with reinforcing the roadway system with TDGCs. Estimated equipment costs for a TDGC reinforced roadway are shown in Table 5.8.

Table 5. 8 Equipment costs associated with a TDGC reinforced HMA roadway

\begin{tabular}{|c|c|c|c|c|c|c|c|}
\hline Type & Quantity & Item & \multicolumn{2}{|c|}{ Rate $(\$ / \mathbf{h r})$} & \multirow{2}{*}{$\begin{array}{c}\text { Hours } \\
20 \\
\end{array}$} & \multicolumn{2}{|r|}{ Cost } \\
\hline CAT 330 & 1 & Excavator & $\$$ & 62.76 & & $\$$ & $1,255.20$ \\
\hline International $\mathrm{HX}$ & 2 & On-Road Trucks & $\$$ & 71.03 & 22 & $\$$ & $3,125.32$ \\
\hline CAT 242D & 1 & Skid steer & $\$$ & 16.09 & 4 & $\$$ & 64.36 \\
\hline $\begin{array}{c}\text { CAT CB54B Tandem } \\
\text { Vibratory Roller }\end{array}$ & 1 & Roller & $\$$ & 48.35 & 56 & $\$$ & $2,707.60$ \\
\hline CAT AP600F & 1 & Paver & $\$$ & 231.67 & 16 & $\$$ & $3,706.75$ \\
\hline Ford & 2 & $\begin{array}{l}\text { Company Trucks (3/4 } \\
\text { Tons Pick-up Trucks) }\end{array}$ & $\$$ & 13.40 & 22 & $\$$ & 589.60 \\
\hline CAT D6N & 1 & Mid-size Dozer & $\$$ & 85.26 & 40 & $\$$ & $3,410.40$ \\
\hline Trimble & 1 & $\begin{array}{c}\text { GPS for Equipment ( } 1 \\
\text { Dozer and Grader) }\end{array}$ & & 000.00 & - & $\$$ & $2,000.00$ \\
\hline 389 Peterbilt & 1 & Truck Tractor & $\$$ & 56.79 & 5 & $\$$ & 283.95 \\
\hline Gooseneck Air Ride Trailer & 1 & $\begin{array}{c}\text { Haul Trailer for Truck } \\
\text { Tractor }(10 \text { Ton }<)\end{array}$ & $\$$ & 21.68 & 5 & $\$$ & 108.40 \\
\hline CAT CT13 Model & 1 & Mechanic Truck & $\$$ & 56.79 & 33 & $\$$ & $1,874.07$ \\
\hline CAT CT13 Model & 1 & Tack Coat Truck & $\$$ & 56.79 & 3 & $\$$ & 170.37 \\
\hline CAT $14 \mathrm{M} 3$ & 1 & Grader & $\$$ & 67.50 & 6 & $\$$ & 405.00 \\
\hline & & & & & TOTAL & $\$$ & $9,701.02$ \\
\hline
\end{tabular}

Estimated labor costs are displayed in Table 5.9 (5\% per Diem is factored into the rates for engineers, the inspector, and the superintendent):

Table 5.9 Labor costs associated with a TDGC reinforced HMA roadway

\begin{tabular}{|c|c|c|c|c|c|c|}
\hline Quantity & Item & \multicolumn{2}{|c|}{ Rate $(\$ / h r)$} & Hours Worked & \multicolumn{2}{|r|}{ Cost } \\
\hline 2 & Surveyors & $\$$ & 31.84 & 2.5 & $\$$ & 159.18 \\
\hline 4 & Laborers (includes Foreman) & $\$$ & 20.07 & 44 & $\$$ & $3,532.32$ \\
\hline 1 & Superintendent & $\$$ & 38.38 & 44 & $\$$ & $1,688.61$ \\
\hline 4 & Operators & $\$$ & 22.15 & 44 & $\$$ & $3,898.40$ \\
\hline 1 & Inspectors & $\$$ & 38.38 & 44 & $\$$ & $1,688.61$ \\
\hline 1 & Engineers & $\$$ & 38.38 & 44 & $\$$ & $1,688.61$ \\
\hline 1 & Diesel Mechanic/Lubricator & $\$$ & 25.58 & 44 & $\$$ & $1,125.60$ \\
\hline & & & & Total & $\$$ & $13,781.33$ \\
\hline
\end{tabular}

Note: Refer to cumulative construction time (44 hours) in Table 5.4 
Estimated item quantity and cost for material reflect typical HMA application with appropriate means of geotextile placement for separation purposes between the subgrade and base/sub base layers. Material rates reflect values obtained from the WVDOT average unit bid prices and from construction professionals. In accordance with Chakrey et al, the water bound macadam was removed from the material listing. Tire-derived geo-cylinders were added to the cost analysis (Table 5.10).

Table 5. 10 Material costs associated with a TDGC reinforced HMA roadway

\begin{tabular}{|c|c|c|c|c|c|c|c|}
\hline Item & CY & Ton & SY & $\begin{array}{c}\text { Number } \\
\text { of } \\
\text { TDGCs }\end{array}$ & \multicolumn{2}{|c|}{ Rate } & Cost \\
\hline $\begin{array}{c}\text { HMA Without } \\
\text { Reinforcement ( } \$ / \text { Ton), } \\
\text { depth of } 4.5 \text { " from } \\
\text { Section } 5.2\end{array}$ & $1,753.00$ & $3,506.00$ & & & $\$$ & 80.00 & $\$ 280,480.00$ \\
\hline $\begin{array}{l}\text { Aggregate (AASHTO } \\
\# 57 \mathrm{~s})(\$ / \text { Ton), depth of } \\
8.23 " \text { from Section } 5.2\end{array}$ & $3,721.00$ & $5,209.40$ & & & $\$$ & 30.00 & $\$ 156,282.00$ \\
\hline $\begin{array}{c}\text { Woven Geotextile } \\
\text { Separation Fabric }(\$ / \mathrm{SY})\end{array}$ & & & $16,426.67$ & & $\$$ & 1.30 & $\$ 21,354.67$ \\
\hline $\begin{array}{l}\text { TDGCs (rate is } \$ 0.50- \\
\$ 3.00 / \text { TDGC; this cost is } \\
\text { to recycle a standard } \\
\text { truck tire) }\end{array}$ & & & & $29,568.00$ & & 1.50 & $\$ 44,352.00$ \\
\hline & & & & & & Total & $\$ 502,468.67$ \\
\hline
\end{tabular}

The overall estimated cost of construction for a non-TDGC reinforced HMA roadway utilizing Chakrey and Pawar (2015) schedule is the summation of equipment, crew, and material costs. Summation of the estimated totals provides a value of $\mathbf{\$} \mathbf{5 3 5 , 9 5 1 . 0 2}$.

$\underline{\text { Conclusions }}$

Estimating construction costs based on the activities assumed by Chakrey and Pawar (2015) shows potential cost differences can be achieved with the use of TDGCs within the pavement system. The non-TDGC reinforced roadway system's final estimated cost was \$ $\mathbf{5 6 6 , 2 4 9 . 5 3}$ compared to that of the TDGC reinforced roadway system which provided a final cost of \$ 535,951.02. The overall cost difference between the non-TDGC and TDGC reinforced HMA roadway is \$ 30,298.51 (6\%). The TDGC reinforced road system shows a potential for cost savings. Further field data needs to be obtained, specifically in regards to production and installation rates for TDGC reinforced road system versus a conventional roadway. 


\section{SUMMARY, CONCLUSIONS, AND FUTURE WORK}

\subsection{Summary and Conclusions}

The following summary and conclusions can be drawn from literature review and laboratory experiments of tire-derived geo-cylinders, geowebs, and other base/sub base property enhancement techniques:

- Pavement deterioration is a problem that plagues current roadway systems and additional forms of reinforcement can enhance the pavement life.

- A compacted subgrade is vital to providing good foundational support to the sub base, base, PCC, and Hot-Mix Asphalt Surface rest on. This can mitigate rutting and pumping which can lead to pavement failure.

- Woven geotextile (separator) fabrics aid in preventing the movement of fines through the subgrade and provide tensile reinforcement to the subgrade. They can facilitate water flow and act as secondary reinforcement when combined with geowebs or TDGCs.

- Evaluations of the pavement sections in the lab were carried out under both low and high load ranges varying between 0.5-1.0 kip and 1.0-4.0 kip.

- Testing in two pavement representative sections in bins showed that the pavement section with TDGCs is subjected to load application, its performance exceeds that of the traditional construction. The large bin proved that even with a lower degree of compaction with saturated soil subgrade, TDGCs provided base/sub base structural support (Case C vs. Case A) with $114 \%$ increase in performance (Section 4.1). The TDGC provided a $33.5 \%$ increase in base/sub base moduli than a base without a TDGC.

- Geowebs and TDGCs (Mechanical Concrete $\left.{ }^{\circledR}\right)$ provide effective confinement.

- In static testing relative to the 12 inch diameter plate, the large TDGC performed $10 \%$ more efficiently than the 6 inch or 8 inch geowebs. Low load range (0.5-1.0 kip) fatigue data indicated that the large TDGC allowed for $13 \%$ less displacement than the 6 inch geoweb and $26 \%$ less displacement than the 8 inch geoweb. 
- Fatigue test results prove the effectiveness of different confinement systems used in this study, such as geowebs and TDGCs in enhancing the sub base properties and resulting in lower displacements due to applied loads. Three-dimensional geowebs and TDGCs outperformed two-dimensional woven geotextile and geogrid-woven geotextile combinations.

- Performing a conservative AASHTO flexible pavement/rigid pavement design for an unreinforced sub base and a reinforced sub base used in fatigue test load from small bin testing, suggests that utilizing TDGCs will contribute to increased performance than the traditional installation practice.

- TDGC's constituents such as the presence of steel belting contribute to improved strength and stiffness performance.

- TDGCs provide improvement to the base/sub base moduli. TDGCs are a green technology that helps reuse of materials by eliminating their journey to landfills or burning as a fuel. The performance and potential cost-effectiveness of the TDGCs supports reason that it is a viable resource along with the geo-polymers for base/sub base reinforcement.

- The Poisson's ratio for unconfined and TDGC confined AASHTO \#57 aggregate, sand, and SM-soil (silty sand) are (0.30 vs. 0.245$),(0.30-0.35$ vs. 0.20$)$, and (0.30 vs 0.101), respectively. The reduced Poisson's ratio shows the effectiveness of confinement by the TDGC (Appendix C). 


\subsection{Future Work and Recommendations}

- Alternative soil specimens with different characteristics should be compared when used as separate, independent subgrade material. This report only covered the SMsoil specimen and its response under fatigue loading.

- Utilize pressure cells within the material layers to track load dispersion throughout the underlying pavement surface in an actual field implementation.

- Different load frequencies can mimic traffic volume fluctuations and should be examined more so for high-density roadway system analyses.

- Field installation and analyses are critical to understanding tire -derived geocylinders and geo-polymer reaction when loaded by vertical stresses. Further field data will enhance our understanding on the behavior of base/sub base enhancement techniques. 


\section{REFERENCES}

Adhikari, S., Khattak, M. J., Sun, X., PhD, McManis, K. L., \& Farmer-Kaiser, M.

(2017). Mechanical Properties of Soil-RAP-Geopolymer for the Stabilization of Road

Base/Subbase. University of Louisianna at Lafayette. pp. 1-136. Ann Arbor: ProQuest LLC.

Alkawaaz, N. G., AL-Badran, Y. M., \& Muutashar, Y. H., (2017). Evaluation of Geogrid-

Reinforced Flexible Pavement System Based on Soft Subgrade Soils Under Cyclic Loading.

Civil and Environmental Research, Vol. 9 (No. 12).

American Association of State Highway and Transportation Officials. (1993). AASHTO guide for design of pavement structures, 1993. Washington, D.C.: The Association.

American Association of State Highway and Transportation Officials. (2018). AASHTO guide for excavation and embankment, Washington, D.C.: The Association.

ASTM C469/C469M-14. (2018). Standard Test Method for Static Modulus of Elasticity and

Poisson's Ratio of Concrete in Compression. ASTM International, West Conshohocken, PA.

ASTM D2487-17. (2017). Standard Practice for Classification of Soils for Engineering Purposes

(Unified Soil Classification System), ASTM International, West Conshohocken, PA.

<https://doi.org/10.1520/D2487-17>

ASTM D422-17. (2017). Standard Test Method for Particle Size Analysis of Soils, ASTM

International, West Conshohocken, PA. <https://doi.org/10.1520/D422-07E2>

ASTM D4318-17e1. (2017). Standard Test Methods for Liquid Limit, Plastic Limit, and Plasticity

Index of Soils, Method B. ASTM International, West Conshohocken, PA.

<https://doi.org/10.1520/D4318-17E01>

ASTM D4718/D4718M-15. (2015). Standard Practice for Correction of Unit Weight and Water Content for Soils Containing Oversize Particles, ASTM International, West Conshohocken, PA. 〈https://doi.org/10.1520/D4718_D4718M-15>

ASTM D698-12e2. (2012). Standard Test Methods for Laboratory Compaction Characteristics of Soil Using Standard Effort (12 400 ft-lbf/ft3 (600 kN-m/m3)), ASTM International, West Conshohocken, PA. <https://doi.org/10.1520/D0698-12E02> 
ASTM D854-14. (2014). Standard Test Methods for Specific Gravity of Soil Solids by Water Pycnometer, ASTM International, West Conshohocken, PA. <https://doi.org/10.1520/D0854-14>

Auburn Aggregates. (2018). Product/Price List.

Bowles, Joseph, PE. (1988). Foundation Analysis and Design. $4^{\text {th }}$ Edition. McGraw-Hill Book Company.

Butler, Mary Ann, and Gregory Burr, et al. (2000). Health Effects of Occupational Exposure to Asphalt. United States Department of Health and Human Services.

Chakrey, A., \& Pawar, P. (2015). Advantages of Mechanical Concrete Road over Conventional Road. International Journal of Innovative Technology and Exploring Engineering (IJITEE), $5(1), 43-46$.

Cleveland, G. S., Button, J. W., \& Lytton, R. L. (2002). Geosynthetics in Flexible and Rigid Pavement Overlay Systems to Reduce Reflection Cracking (Project No. 0-1777, Rep. No. FHWA/TX-02/1777-1). College Station, TX: The Texas A\&M University System.

Eck, Ron \& Morgan, Andrew. (2018). West Virginia Local Technical Assistance Program. West Virginia University. Country Roads \& City Streets. (pp. 8-9, Vol. 33, No.1)

Garber, N. J., \& Hoel, L. A. (2009). Traffic and highway engineering. Toronto: Cengage Learning. Gillespie, T.D., and M. Sayers. (1981). Role of Road Roughness in Vehicle Ride. Committee on Pavement Condition Evaluation. Transportation Research Board. TRB 836.

Huynh, Philip. (2012). Price Index for Selected Highway Construction Items. California Department of Transportation.

Janoo, V. (1998). Quantification of Shape, Angularity, and Surface Texture of Base Course Materials. U.S. Army Corps of Engineers. Special Report-98-1.

Jung, Y. S. (2010). Advancement of Erosion Testing, Modeling, and Design of Concrete Pavement Subbase Layers (Doctoral dissertation, 2010). UMI Dissertation Publishing. 
Khalaj, O., Tafreshi, S. N., Mask, B., \& Dawson, A. R. (2015). Improvement of pavement foundation response with multi-layers of geocell reinforcement: Cyclic plate load test. Geomechanics and Engineering, 9(3), 373-395.

Kief, Ofer \& Karpurapu, Rajagopal. (2008). Three Dimensional Cellular Confinement System Contribution to Structural Pavement Reinforcement.

Koerner, R. M. (2005). Designing with geosynthetics. New Jersey: Prentice-Hall.

Little, D. N. (1999). Evaluation of Structural Properties of Lime Stabilized Soils and Aggregates (Vol. 1, pp. 1-97, Rep.). National Lime Association.

Little, D. et al. (2003). Quantify Shape, Angularity and surface Texture of Aggregates Using Image Analysis and Study Their Effect on Performance. Texas Department of Transportation. Texas transportation Institute. Report 0-1707-4.

Maher, Ali, et al. (2008). Evaluation of Poisson's Ratio for Use in the Mechanistic Empirical Pavement Design Guide (MEPDG). New Jersey Department of Transportation. Rutgers University.FHWA-NJ-2008-004.

Mechanical Concrete ${ }^{\circledR}$. WVDOH. (2009). Field Report Morgan's Run Road/Israel Fork. Doddridge County, WV.

Mollenhaurer, K., Pais, J., Wistuba, M., \& Rabe, R. (2009). FourPointBending: Proceedings of the second workshop. Guimarães: Universidade do Minho. Escola de Engenharia.

Mukabi, J. N. (2013). Proposed Geoscientific Method of Determining Optimum Geosynthetics Embedment Location for Enhanced Performance of Geo-structures. International Conference on Geotechnical Engineering (pp. 1-10).

Newcomb, D., Timm, D., Mahoney, J. (2002). It's Still Dirt, Rocks, and Asphalt -Right. Hot Mix Asphalt Technology. <asphaltpavement.com.>

Ntirenganya, N., De Wet, M., PhD, \& Kalumba, D., PhD. (2015). An Investigation of the Interlayer Adhesion Strength between the Granular Base and Lightly Cemented Subbase and Its Influence on the Pavement Performance. Stellenbosch: Stellenbosch University. 
Occupational Safety and Health Administration. (2017). OSHA's Respirable Crystalline Silica Standard for Construction.

Pavement Interactive. (2012). “1993 AASHTO Rigid Pavement Structural Design.” Pavement Interactive MicroMilling the Finer Side of Milling Comments

Setegn, Amare. (2012). Software Development for the AASHTO and ERA Flexible Pavement Design Methods. Addis Ababa Institute of Technology. Department of Road and Transportation Engineering

Soil Survey Staff. (2018). Natural Resources Conservation Service, United States Department of Agriculture. Web Soil Survey. <https://websoilsurvey.sc.egov.usda.gov/>.

StrataWeb. (2014). Re-construction of Major District road in Nashik with StrataWeb®. Nashik, Maharashtra, India

Tang, X., Palomino, A. M., \& Stoffels, S. M. (2011). A study of permanent deformation behavior of geogridreinforced flexible pavements using small scale accelerated pavement testing (Doctoral dissertation, 2011). UMI Dissertation Publishing.

The National Institute for Occupational Safety and Health (NIOSH). Centers for Disease Control and Prevention, "Preventing Silicosis and Deaths in Construction Workers”, 6 June 2014

United States Department of Labor. Occupational Safety and Health Administration. Respirable Crystalline Silica. 29 CFR1926.1153

<www.osha.gov/laws-regs/regulations/standardnumber/1926/1926.1153.>

U.S. Department of Transportation, Federal Highway Administration. (2017). "Bridges \& Structures".

U.S. Department of Transportation. Federal Highway Administration. (2012). User's Guide: Estimation of Key PCC, Base, Subbase, and Pavement Engineering Properties from Routine Tests and Physical Characteristics. FHWA-HRT-12-031.

U.S. Department of Transportation. Federal Highway Administration. (2016). User Guidelines for Waste and Byproduct Materials in Pavement Construction. FHWA-RD-97-148. 
United State Department of Transportation. Federal Highway Administration. (2015). Strength Characterization of Open-Graded Aggregates for Structural Backfills. FHWA-HRT-15-034.

United State Department of Transportation. Federal Highway Administration. (2013). Friction Angles of Open-Graded Aggregates from Large-Scale Direct Shear Testing. FHWA-HRT-13-068.

U.S. Tire Manufacturers Association (2018). "What's In a Tire?" <www.ustires.org/whats-tire-0.>

West Virginia Division of Highways Draft General Specification, Reinforced Aggregate Company. (2013). Proposed Specification for the Construction of Mechanical Concrete ${ }^{\circledR}$ Geocylinder Confinement Systems For Roadway Base or Shoulders, Gravity Retaining Walls or Mechanically Stabilized Earth (MSE) Walls, Load Bearing Walls, Abutments or Load Bearing Pier Foundations.

Wolfe, A. J., White, D., Shaefer, V., and Iverson, N. (2011). Behavior of composite pavement foundation materials subjected to cyclic loading (Master's thesis, 2011). UMI Dissertation Publishing.

Yap, Pedro. (1989). Truck Tires and Road Contact Pressures. The Goodyear Tire and Rubber Company.

Yilmaz, I. (2006). Indirect estimation of the swelling percent and a new classification of soils depending on liquid limit and cation exchange capacity. Engineering geology, 85, 295-301

Zornberg, J., \& Gupta, R. (2009). Reinforcement of pavements over expansive clay subgrades. In Proceedings of the 17th International Conference on Soil Mechanics and Geotechnical Engineering (pp. 765-768). IOS Pres 


\section{APPENDICES}

\section{Appendix A: Silica Safety Concerns}

Since silica based fine and coarse aggregate are extensively used in the pavement industry for both asphalt and concrete pavements, this section highlights the safety measures suggested by OSHA and NIOSH when silica is present during construction. Safety concerns towards airborne hazards have become significantly more relevant especially concerning silica exposure. The National Institute for Occupational Safety and Health (NIOSH) has been researching and experimenting new technological advancements with hopes of mitigating such hazards. People working in the construction industry and equipment/machinery industry have had exposure to silica in some manner. About two million construction workers are exposed to respirable crystalline silica in over 600,000 workplaces (OSHA, 2017).

Silica is a common component of soil and rock materials. Forms of silica are quartz (most common), cristobalite, and tridymite. Silica particles enter the body typically by way of inhalation during exposure, and the health hazards associated with silica are very dangerous, and potentially, life threatening. It has been identified as a lung carcinogen (has the ability to cause cancer). Silicosis, a respirable disease associated with silica exposure, has no known cure (Butler, 2000). The ability of silica to damage the lungs and respiratory system makes patients more susceptible to develop tuberculosis, as well. There are three main types of silicosis which workers may encounter: 1) acute silicosis (2) accelerated silicosis and (3) chronic silicosis. Acute silicosis is more likely observed in patients where there are high exposure environments. This type results in shortness of breath, weight loss, weakening of the body, and often causes death. Accelerated silicosis results due to high exposure, but takes nearly 5-10 years to fully develop. Chronic silicosis is most common and occurs long after initial exposure. Timeframe for the development of chronic silicosis is $\mathbf{1 5 - 2 0}$ years even with low silica association. In later stages of chronic silicosis, lung damage, shortness of breath, chest pains, and respiratory failure may occur. OSHA, NIOSH, The National Asphalt Pavement Association, and several other entities have performed and developed reports that describe the measures to make the workplace safer against silica exposure.

Silica exposure could not be fully eradicated in several of the previously stated professions, but it can be minimized. Silica can be found in concrete and masonry work, chipping/crushing and 
drilling of rock, surface blasting with silica abrasives, structure demolition, pressurized air blowing into rock, concrete, or dust, backfilling/excavation, and highway construction such as paving and milling (Eck and Morgan, 2018). The main focus of this section is to review and discuss known effects of silica in highway construction and provide a potential minimization scheme to reduce silica in field work. Two NIOSH case studies with respect to rigid pavement, flexible pavement, and aggregate exposure are discussed pertaining to highway construction processes and silica.

The first case study involved daily oversight of a construction crew performing interstate highway repair. Four workers conducted drilling operations into the concrete pavement to remove the damaged section of pavement. Two of the workers operated backhoes with drill attachments and the other two workers positioned the drills in appropriate locations. Dust collection devices were not in place, water suppression was not performed, and unsatisfactory breathing devices were used that only covered half and quarter sections of the nose and mouth. Samples were taken on two separate days with permissible exposure limits (PELs) exceeding the recommended OSHA standard. Both testing sessions revealed unsafe silica amounts at the construction site (NIOSH, 2014). Respirable crystalline silica exposures above the PEL of $50 \mu \mathrm{g} / \mathrm{m}^{3}$, averaged over an 8-hour day are considered highly hazardous (OSHA, 2017). The second case study was an in depth field evaluation of pavement milling in Buffalo Gap, South Dakota by the Silica/Milling-Machines Partnership in coordination with The National Asphalt Pavement Association. The study shows time dependent results for water-spray systems used to suppress silica on pavement milling machines. Workers were exposed to silica in the study and monitoring measures conducted in field application helped find a potential solution via water suppression to minimize airborne health hazards.

Tire-derived geo-cylinders and geo-polymers could provide a pro-active approach to reduction of silica exposure in highway construction. From laboratory analyses, we have determined that rigid pavements, flexible pavements, and plain aggregate based roads reinforced with TDGCs and geo-polymers can potentially decrease usage of aggregate and prevent sideways escape of airborne silica particles due to the presence of cylindrical sidewalls. The reduction of material along with dust mitigation and labor is important as it may lead to faster, healthier and greener roadway construction. Workers are still required to wear appropriate respirators and proper 
personal protective equipment (PPE) as well as have access to premium air flow/ventilation per OSHA Standards (29 CFR 1926.1153).

\section{Appendix B: TDGCs: Healthier, Greener Alternative}

The proper reuse of tires has plagued the recycling industry for several years. A 2016 report from the USDOT and Federal Highway Administration (FHWA) stated that roughly 250 million tires are generated on an annual basis with 7\% of the scrap tires going to foreign countries, $8 \%$ creating new products, and $40 \%$ are used as tire-derived fuel (USDOT-FHWA, 2016). Currently, one of the largest uses for scrap tires is as fuel for power plants, paper mills, and various other industrial heating systems. Of the roughly 30 million tires that are not discarded each year, most go to retreaders, who retread about one-third of the tires received (USDOT-FHWA, 2016). With dissipating numbers of retreaders in the United States, increased focus has been placed concerning other methods for tire recycling.

There are many concerns regarding tire storage and disposal. Tire storage locations can have high fire risk. Tires burn very hot and the make-up of tires makes them extremely difficult to extinguish. Once burned, tires can create oily substances which can contaminate water and be a direct hazard to people. Burning tires can also release airborne chemicals which have potential of harming residents within proximity.

According to the FHWA, tires have been reused in various applications. One such use is as a fill material for embankment construction. Tires have also been chipped and placed within asphalt as a substitute to aggregate, and they have been installed on roadway shoulders to provide reinforcement. Tires have also been utilized for non-roadway construction practices such as retaining wall and slope stabilization structures.

Large scale usage of recycled tires is hindered by the limited data researchers and professionals have regarding their mechanical, thermal, and chemical properties. The composite system of carbon black, woven steel belting, oil, and various other substances create a durable, heat-efficient mechanism that make them attractive for various applications. It is important to further understand the application potential of recycled tires and evaluate their mechanical properties to expand their use as a green and innovative technology. 


\section{Appendix C: Confinement Testing TDGCs and Geo-Polymers}

This section aims to provide understanding in regards to the confinement effect which occurs within the TDGCs and geo-web/cells. Static analysis was conducted on three materials: AASHTO \#57 aggregate, sand, and SM-soil. Micro-confinement testing was conducted on the TDGC-S to observe the expansion of the specimen in regards to the three infill materials.

\section{C.1 TDGC and Geo-polymer Confinement Comparison and Bearing Capacity Calculation}

Confinement testing was performed to help understand the load vs. displacement relationship in TDGCs and geowebs. The 8" geoweb, 6" geoweb, TDGC-S, and TDGC were used for evaluating confinement effects. Experiments and data collection were performed by an Instron Testing System. Two loading plates were utilized, an 11" diameter cylindrical plate $\left(95 \mathrm{in}^{2}\right)$ and a diamond-shaped plate with a surface area of $40 \mathrm{in}^{2}$ (Figure C.1) that conformed to the opening shape of a geoweb. The 11 " in diameter plate was used to ensure the interior fill material of the TDGC-S and TDGC was nearly covered on the top surface with a small gap on the sides during load application. The load was applied (rate of $0.1 \mathrm{in} / \mathrm{min}$ ) on the top of the steel plate within the walls of the confinement schemes used for testing. This test ensures that the infill material will be pushed outward causing lateral stresses to be applied on the reinforcing sidewalls of the TDGCs and geowebs which in turn results in confinement. Three types of fill materials (AASHTO \#57 aggregate, sand, and SM-soil) were tested for confinement.

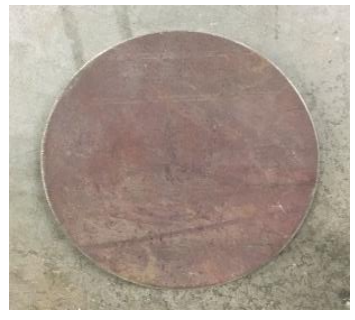

(a)

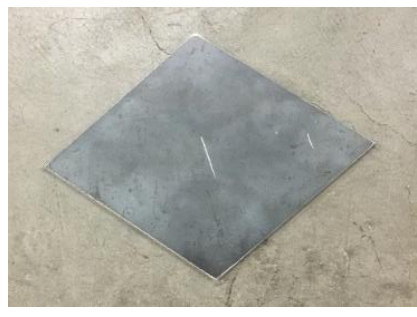

(b)

Figure C. 1 Loading plates utilized while testing for confinement

(a) 11" diameter plate (b) $40 \mathrm{in}^{2}$ surface area plate 


\section{C.1.1 Confinement Test Procedures}

Infill specimens of AASHTO \#57 Aggregate, sand, and SM-soil (Figure C.2) were placed within the Instron System and filled with each material. Two displacement limits were set regarding the different infill materials. A limit of 0.75 " was used for the interior of the TDGC-S and TDGC whereas a limit of 0.50 " applied to geoweb testing. A minimum of four tests were conducted on each reinforcement specimen per infill material. The final base/sub base modulus value from testing was taken and used for comparison.

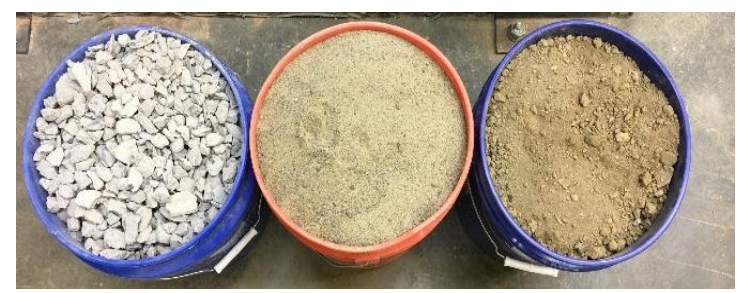

Figure C. 2 Infill Materials (AASHTO \#57 Aggregate, sand, SM-soil) for filling TDGCs and geowebs for confinement tests

\section{C.1.2 Confinement Testing Data}

Various testing was performed in regards to confinement reinforcement specimens and Figure C. 3 displays some of the testing scenarios that were examined.

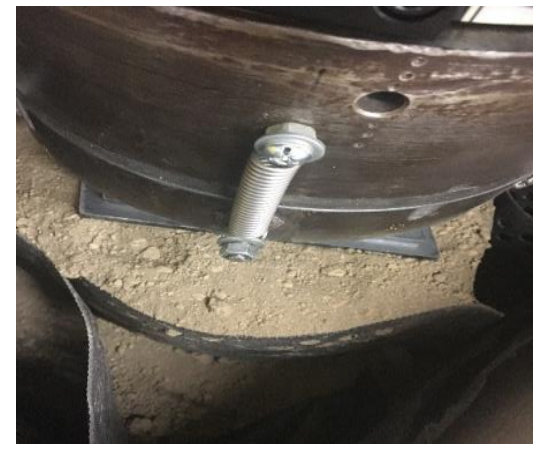

(a)

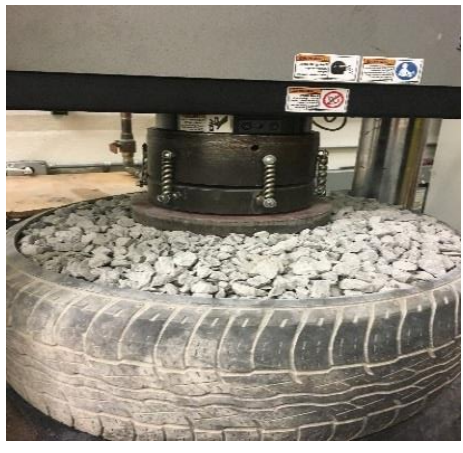

(b)

Figure C. 3 Confinement testing (a) 8" geoweb single cell filled with SM-soil

(b) TDGC filled with AASHTO \#57 aggregate 
The data reflects how well the TDGCs and the geowebs performed when vertical forces induced lateral stresses. Data pertaining to the 0.75 " and 0.50 " displacement limits are shown in Figures C.4 and C.5. The opening sizes for a single cell in 8" and 6" geoweb was identically 12.6"x11.3". The inner diameters of the TDGC and TDGC-S are 16" and 24", respectively.

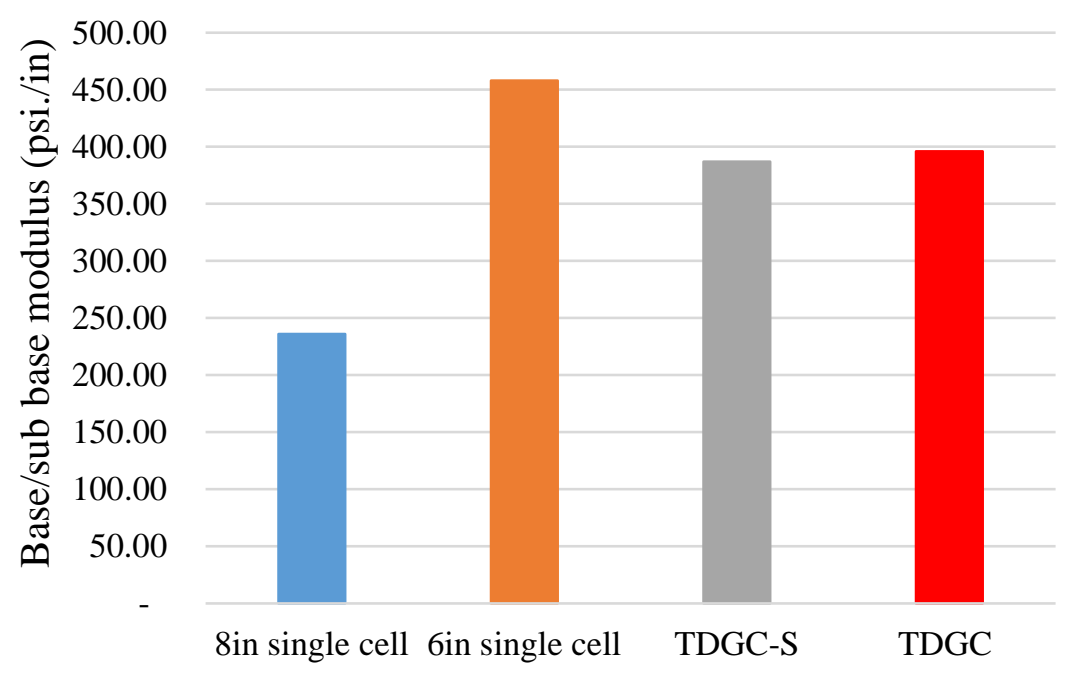

Figure C. 4 AASHTO \#57 confinement tests for single cells of geowebs and TDGCs

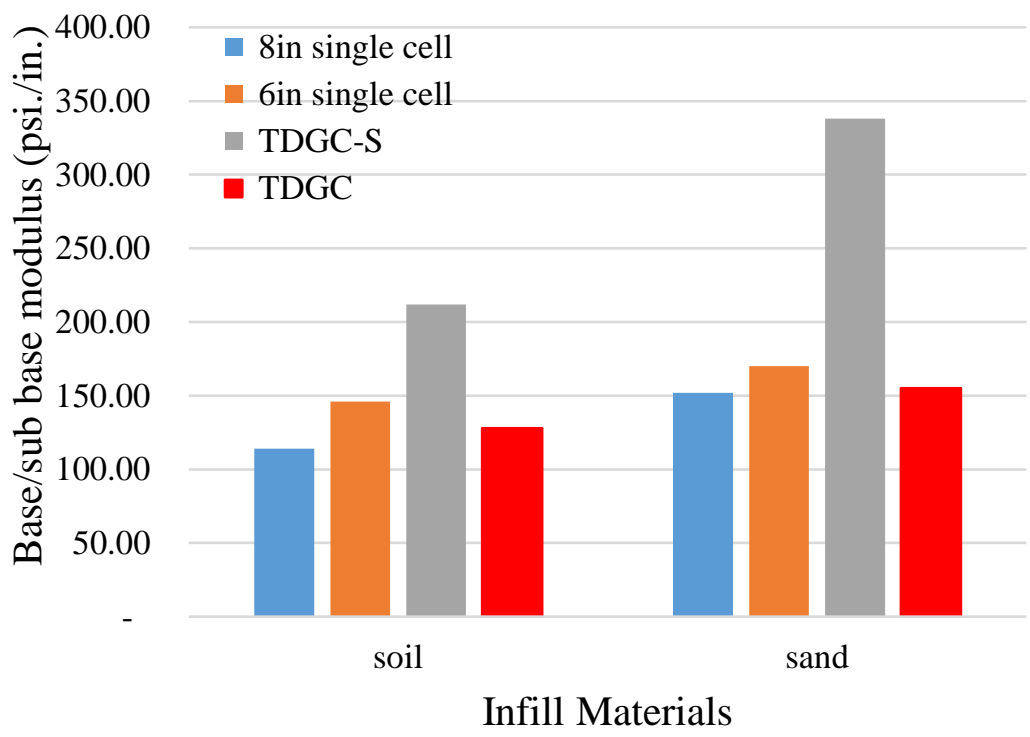

Figure C. 5 SM-soil and sand confinement tests

The data shows that the TDGCs and geowebs provide confinement effects in Figure C.4. The data in Figure C.5 shows the confined soil and sand base/sub base moduli from the geowebs, 
TDGC-S, and TDGC. The TDGC-S performed more efficiently when filled with soil and sand. It is well understood that the confinement effects are inversely proportional to the diameter of the confining cylinder and higher confinement is observed with the smaller diameter TDGC-S (16" diameter) as compared to the TDGC (24" diameter). The geowebs performed relatively about the same; however, the 6" geoweb with smaller heights showed slightly better values than the 8"high geowebs. The TDGC performed nearly identical when exposed to the SM-soil and sand.

\section{C.1.3 Bearing Capacity from Confinement}

Calculations have been performed for the bearing capacity of a base/sub base material (i.e. AASHTO \#57 aggregate) following the installation of TDGCs. This section aims to provide potential bearing capacities by using the bearing capacity formula for geo-polymers in relation to the TDGC. The referenced equation and example discuss the bearing capacity for 8 " geowebs (Koerner, 2005).

(Equation C.1) Bearing Capacity Formula for installed geo-polymer mattress (Koerner, 2005)

$$
\rho=2 \tau+\mathrm{cN}_{\mathrm{C}} \zeta_{\mathrm{C}}+\mathrm{qN}_{\mathrm{q}} \zeta_{\mathrm{q}}+0.5 \gamma \mathrm{BN}_{\gamma} \zeta_{\gamma}
$$

$\rho=$ maximum bearing capacity

$\tau=$ shear strength between material and cell $\left(=\sigma_{\mathrm{h}} \tan \delta\right)$

$\sigma_{\mathrm{h}}=$ average horizontal force within cell $\left(=\mathrm{p} \mathrm{K} \mathrm{K}_{\mathrm{a}}\right)$

$\mathrm{p}=$ applied vertical force

$K_{a}=$ coefficient of active earth pressure, Rankine Theory $\left(K_{a}=\tan ^{2}(45-\Phi / 2)\right.$

$\delta=$ angle of shearing resistance between infill material and cell wall

$\mathrm{c}=$ cohesion (zero for granular soil such as sand)

$\mathrm{N}_{\mathrm{c}}=$ bearing factors which are a function of $\Phi$ (or friction angle)

$\zeta_{\mathrm{c}}=$ shape factors

$\mathrm{q}=$ surcharge load $\left(=\gamma_{\mathrm{q}} \mathrm{D}_{\mathrm{q}}\right)$

$\gamma_{\mathrm{q}}=$ unit weight of material inside cell

$\mathrm{D}_{\mathrm{q}}=$ depth of cell

$\mathrm{N}_{\mathrm{q}}=$ bearing factors which are a function of $\Phi$ (or friction angle)

$\zeta_{\mathrm{q}}=$ shape factors

$\gamma=$ unit weight of material in failure zone

$\mathrm{B}=$ width of applied pressure system

$\mathrm{N}_{\gamma}=$ bearing factors which are a function of $\Phi$ (or friction angle)

$\zeta_{\gamma}=$ shape factors 
(Equation C.2) Expanding the formula above:

$$
\rho=\left(2 \mathrm{p} \tan ^{2}\left(45-\frac{\Phi}{2}\right) \tan \delta\right)+\left(\mathrm{cN}_{\mathrm{C}} \zeta_{\mathrm{C}}\right)+\left(\gamma_{q} D_{q} \mathrm{~N}_{\mathrm{q}} \zeta_{\mathrm{q}}\right)+\left(0.5 \gamma \mathrm{BN} \mathrm{N}_{\gamma} \zeta_{\gamma}\right)
$$

The components of the equation were solved the summed. Assumptions are provided below regarding the data placed in this formula. Bearing capacity values are calculated in Table C.1.

The following data is in regards to computations performed by Koerner to provide potential values in regards to bearing capacities for TDGCs which contains AASHTO \#57 aggregate fill. Values are suggested based on reasonable computation. Actual data may slightly differ in some regards. Assumptions for the bearing capacity calculation are as follows:

Maximum load from TDGC testing was 28,000 lbs. over a cylindrical surface area of $95 \mathrm{in}^{2}$.

$>$ As per the USDOT-FHWA (2013), the Mohr-Coulomb Dry friction angle is $52^{\circ}$.

$>$ As per the USDOTFHWA (2015), the minimum unit weight of AASHTO \#57 is 95.4 pcf (pounds per cubic foot) or 0.055 pci (pounds per cubic inch).

$>$ Depth of the TDGC is approximated at 8 inches.

$>$ Bearing factors $(\mathrm{N})$ were utilized from the Bowles (1988).

$>$ Nominal aggregate size was determined from Laurel Aggregates and determined to be $25 \mathrm{~mm}$ (or $\sim 1$ inch)

The shape factor is assumed to be 0.5 which assumed based on examination of literature. (Janoo, 1998; Little, 2003)

$>$ Cohesion (c) is assumed to be zero. 


\begin{tabular}{|c|c|c|c|c|c|c|c|c|c|c|c|c|c|c|c|c|c|c|c|}
\hline & & 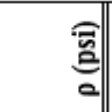 & 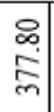 & $\begin{array}{l}\hat{n} \\
\hat{m}\end{array}$ & ०. & 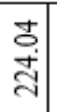 & 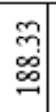 & $\begin{array}{l}\text { สี } \\
\text { 이 }\end{array}$ & 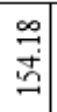 & $\begin{array}{l}\text { 으 } \\
\text { 守 } \\
\text { - }\end{array}$ & 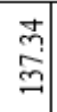 & 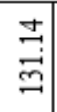 & \begin{tabular}{l|} 
\\
0 \\
0 \\
0 \\
-
\end{tabular} & 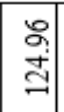 & 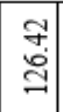 & 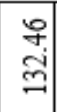 & 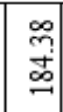 & $\begin{array}{l}\text { g } \\
\text { cि }\end{array}$ & \\
\hline & & 紊 & 잉 & $\stackrel{9}{0}$ & 웡 & $\begin{array}{l}\infty \\
\stackrel{2}{0} \\
0\end{array}$ & 욤 & $\overrightarrow{\text { p. }}$ & $\begin{array}{l} \pm \\
+\end{array}$ & ?ֶ. & ง & $\begin{array}{l}8 \\
\\
\end{array}$ & 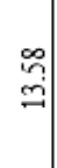 & $\left|\begin{array}{l}\vec{b} \\
\stackrel{0}{a}\end{array}\right|$ & 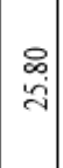 & స్టి & $\mid \begin{array}{l}\mid \\
\vdots \\
0 \\
0 \\
\infty\end{array}$ & 8 & \\
\hline & & 5 & 유. & 융 & 융 & 융 & 융 & 유. & 유. & $\begin{array}{l}\text { 잉 } \\
\text { : }\end{array}$ & 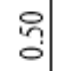 & 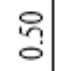 & $\begin{array}{l}0 \\
0 \\
0\end{array}$ & 유. & $\mid \begin{array}{l}0 \\
0 \\
0\end{array}$ & $\begin{array}{l}0 \\
0 \\
0\end{array}$ & 융 & E & \\
\hline & & 玄 & ㅇ. & 웅 & త్రి & $\stackrel{\circ}{\circ}$ & 움 & 응 & 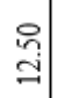 & 잉 & $\begin{array}{l}\stackrel{ }{1} \\
\text { in }\end{array}$ & స్లి & $\begin{array}{l}8 \\
\dot{y}\end{array}$ & ิㅗㅇ & $\begin{array}{c}\stackrel{2}{\circ} \\
\stackrel{1}{1}\end{array}$ & $\begin{array}{l}0 \\
0 \\
\text { à }\end{array}$ & 忿 & ल) & \\
\hline & & 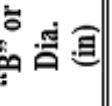 & $\begin{array}{l}8 \\
\text { ¿ } \\
\dot{1}\end{array}$ & $\begin{array}{l}\text { 8े } \\
\text { ㄱ. }\end{array}$ & 임 & $\begin{array}{l}8 \\
\text { ํ. }\end{array}$ & $\begin{array}{l}8 \\
\text { ¿े }\end{array}$ & $\begin{array}{l}8 \\
\stackrel{1}{0}\end{array}$ & $\begin{array}{l}8 \\
\stackrel{1}{+} \\
\end{array}$ & $\begin{array}{l}8 \\
\text { ㅇ. }\end{array}$ & $\begin{array}{l}8 \\
\text { ㅁ. }\end{array}$ & $\begin{array}{l}8 \\
\text { ¿. } \\
\dot{j}\end{array}$ & $\begin{array}{l}8 \\
\text { 에 }\end{array}$ & $\begin{array}{l}8 \\
\text { 어 }\end{array}$ & 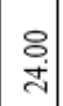 & $\begin{array}{l}8 \\
\dot{1} \\
\text { 1 }\end{array}$ & $\begin{array}{l}8 \\
\text { in }\end{array}$ & $\stackrel{8}{£}$ & \\
\hline & & $=-$ 跑 & 잉. & ㅇ. & 잉 & : & 웅. & 웅. & 웅. & 임. & 잉. & 잉. & 잉. & 号 & : & 임 & : & है & \\
\hline 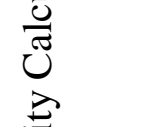 & & 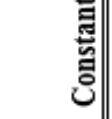 & 융 & 융 & 융 & ำ & 융 & 융 & 윰 & 응 & 융 & 융 & 응 & 员: & $\begin{array}{l}0 \\
\text { : } \\
\end{array}$ & 응 & 응 & 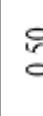 & \\
\hline 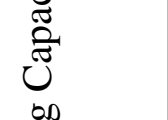 & & 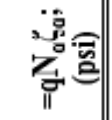 & ปี & ติ & ถู่ & 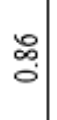 & 导 & 익 & $\begin{array}{l}\overrightarrow{0} \\
ن\end{array}$ & ปે & $\begin{array}{l}\circ \\
\text { 임 }\end{array}$ & \begin{tabular}{c}
$?$ \\
\hdashline \\
\end{tabular} & 黾 & స్ & $\begin{array}{l}0 \\
0 \\
0\end{array}$ & ? & 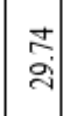 & હૈ & \\
\hline$=$ & & 2 & 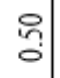 & ํํㅇ & ํํㅇ & ํํㅇ & ํํㅇ & ํำ & 응 & ํํㅇ & 유 & 용. & ㅇํㅇ & 号 & $\mid \begin{array}{l}0 \\
0 \\
0\end{array}$ & $\begin{array}{l}0 \\
0 \\
0\end{array}$ & $\mid \begin{array}{l}0 \\
0 \\
0\end{array}$ & 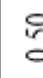 & \\
\hline & & $z^{0}$ & $\stackrel{8}{-}$ & 여- & ㅇํ & 일 & 웅. & $\begin{array}{l}\text { 잉 } \\
\stackrel{0}{0}\end{array}$ & $\stackrel{\infty}{=}$ & $\begin{array}{l}\stackrel{8}{ \pm} \\
\pm\end{array}$ & $\begin{array}{l}\text { 오․ } \\
\stackrel{0}{a}\end{array}$ & సి & $\begin{array}{l}\text { ㅇ․ } \\
\text { aे }\end{array}$ & 일 & $\begin{array}{c}\text { \& } \\
\text { o } \\
\text { o }\end{array}$ & $\begin{array}{l}\text { 임 } \\
\text { 항 }\end{array}$ & 욤 & $\frac{c}{m}$ & \\
\hline 0 & & a & $\underset{\infty}{\stackrel{0}{0}}$ & $\underset{\infty}{\stackrel{0}{0}}$ & 임 & $\underset{\infty}{\stackrel{0}{0}}$ & $\underset{\infty}{\stackrel{\infty}{0}}$ & $\underset{\infty}{8}$ & $\underset{\infty}{\stackrel{0}{0}}$ & : & : & : & \& & $\begin{array}{c}8 \\
\infty \\
\infty\end{array}$ & $\begin{array}{l}8 \\
8 \\
\infty\end{array}$ & $\begin{array}{c}8 \\
\infty \\
\infty\end{array}$ & $\begin{array}{c}8 \\
0 \\
\infty\end{array}$ & 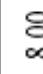 & \\
\hline & & $\sigma$ & : & : & : & : & : & 웅. & : & 웅. & 잉. & 잉. & 응 & \begin{tabular}{|l|} 
\\
\\
\end{tabular} & 号: & 웅 & : & c & \\
\hline & & 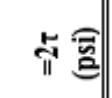 & 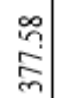 & 总 & 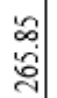 & సิ & 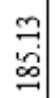 & ๙ู่ & $\begin{array}{l}\stackrel{q}{q} \\
\stackrel{g}{q}\end{array}$ & స్తి & 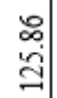 & 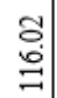 & $\begin{array}{l}a \\
\vdots \\
\vdots \\
o\end{array}$ & $\begin{array}{l}m \\
\vdots \\
\vdots \\
\vdots\end{array}$ & \begin{tabular}{l|}
$\widetilde{a}$ \\
$\infty$ \\
$\infty$
\end{tabular} & $\begin{array}{l}\text { 영 } \\
\text { in }\end{array}$ & $\mid$\begin{tabular}{l}
$\infty$ \\
\multirow{1}{0}{} \\
\end{tabular} & है & \\
\hline & & : & 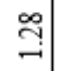 & $\stackrel{\sim}{-}$ & 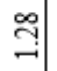 & 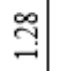 & 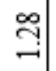 & 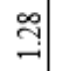 & 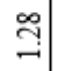 & 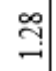 & 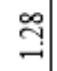 & 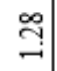 & 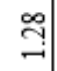 & 吕 & 足 & 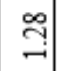 & $\stackrel{\infty}{-1}$ & g & \\
\hline & & $\infty \subsetneq$ & 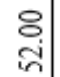 & 옴. & 옴 & ㅇ. & 움. & 옴. & 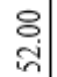 & 옴 & 오․ & 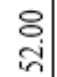 & 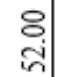 & $\begin{array}{c}8 \\
8 \\
\text { in }\end{array}$ & $\begin{array}{c}8 \\
\text { ․ } \\
\text { in }\end{array}$ & 어․ & 오․ & 8 & \\
\hline 5 & & $\mathfrak{q}$ & $\underset{-}{8}$ & $\begin{array}{l}\mathbf{D} \\
\stackrel{0}{0}\end{array}$ & $\begin{array}{l}\text { 융 } \\
\text { : }\end{array}$ & م્م & 守 & 守 & ్ㅣㅇ & ) & m. & $\vec{m}$ & ণి & ํㅗㅇ & ît & สิ & 7 & $\frac{9}{c}$ & \\
\hline & $\overrightarrow{0}^{*}$ & ๑ฮ & 8 & 8 & 웅 & 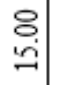 & 움. & $\begin{array}{l}8 \\
\text { ¿ุे. }\end{array}$ & 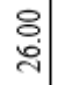 & $\begin{array}{l}8 \\
8 \\
\text { ¿े. }\end{array}$ & 유. & $\begin{array}{l}8 \\
\text { ते } \\
\text { r. }\end{array}$ & $\begin{array}{l}8 \\
\dot{0} \\
\dot{m}\end{array}$ & $\left|\begin{array}{l}8 \\
8 \\
0 \\
\end{array}\right|$ & $\begin{array}{c}8 \\
8 \\
0 \\
j\end{array}$ & $\begin{array}{l}8 \\
\text { o. }\end{array}$ & $\begin{array}{c}8 \\
\\
4 \\
\end{array}$ & 8 & \\
\hline & & a & $\begin{array}{l}8 \\
6 \\
\stackrel{2}{a}\end{array}$ & 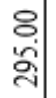 & 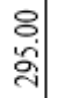 & 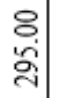 & $\begin{array}{c}8 \\
\text {. } \\
\text { à }\end{array}$ & 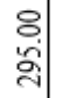 & 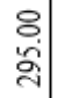 & $\begin{array}{l}8 \\
\text { : } \\
\text { ¿ें }\end{array}$ & $\begin{array}{l}8 \\
\text { : } \\
\text { ते }\end{array}$ & $\begin{array}{l}8 \\
\text {. } \\
\text { ลे. }\end{array}$ & $\begin{array}{l}8 \\
\text { : } \\
\text { ลे. }\end{array}$ & 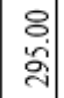 & $\begin{array}{l}8 \\
8 \\
\text { à } \\
\end{array}$ & 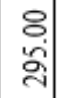 & $\begin{array}{l}8 \\
0 \\
6 \\
\text { à }\end{array}$ & $\begin{array}{l}8 \\
\text { co }\end{array}$ & \\
\hline
\end{tabular}




\section{C.1.4 Conclusion to TDGC and Geo-polymer Confinement Testing}

Based on the confinement testing carried out in this research, base/sub base moduli were observed in increase for AASHTO \#57 aggregate, SM-soil, or sand when they are confined. Cellular confinement is expected to increase the mechanical and physical properties of infill material, and this results in higher lateral stresses and resistance on the cell walls. This behavior is noted in other research (Kief, 2008). Data suggests that these confinement technologies have the potential to decrease soil punching, rutting, and increase the bearing capacity.

\section{C.2 Confinement Testing of Instrumented TDGC-S to Establish Poisson's Ratio}

This section examines confinement for the composite system consisting of thin-walled recycled tire-derived geo-cylinders (TDGC) and the AASHTO \#57 aggregate, also known as Mechanical Concrete®.

\section{C.2.1 Confinement Testing Procedure for Instrumented TDGC-S}

A TDGC-S with three different types of infill material were tested similar to ASTM C469/C469M-14, Standard Test Method for Obtaining Modulus of Elasticity and Poisson's Ratio of Concrete in Compression. Strains were measured in the X-direction (hoop) and Z-direction (axial). The strain in the X-direction (hoop) was measured using three dial gauges around the circumference of the TDGC-S, and the strain in the Z-direction (axial) was measured via a LVDT resting on a load plate. Displacements were assumed to be all positive values. It is important to note that the hoop strains are tensile and the axial (vertical) strains are compressive. Load was applied through an 11" diameter load plate (previously referenced in Section 8.1) resting on top of the infill material in the center of the TDGC-S. StrainSmart Software and an Instron Testing System were used to apply load at a rate $0.1 \mathrm{in} / \mathrm{min}$ and record data. Load was measured with a 50 kip load cell. A typical test set-up is shown in Figure C.6. 

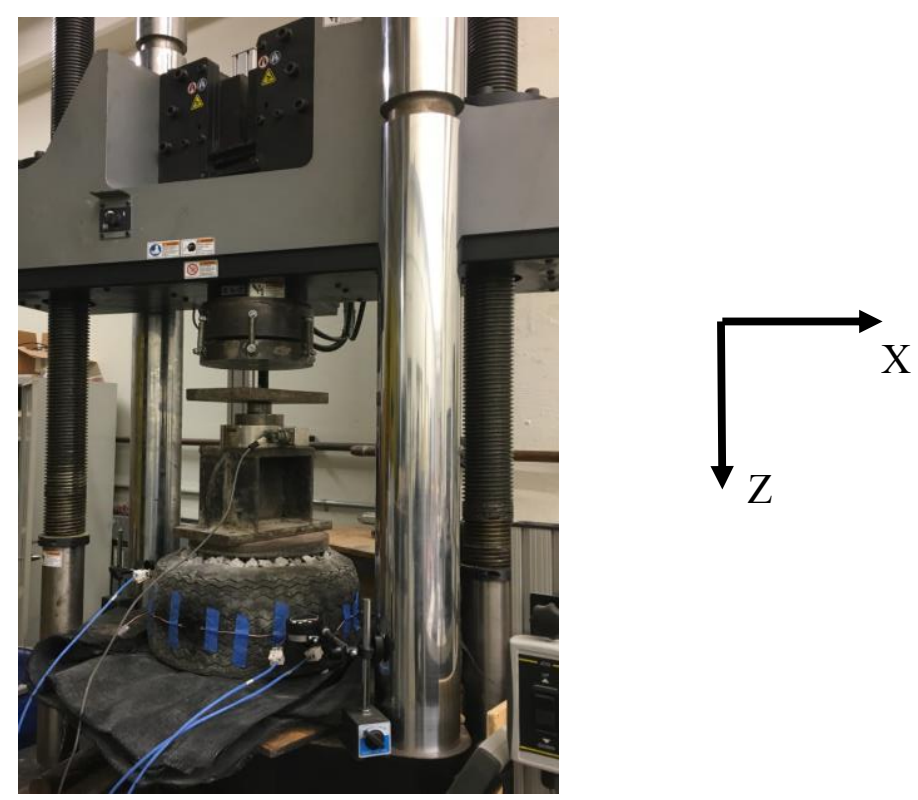

Figure C. 6 Confinement testing of instrumented TDGC-S

\section{C.2.2 Confinement Test Data for Instrumented TDGC-S}

This data is representative of three infill materials (AASHTO \#57 aggregate, sand, and SM-soil) within a TDGC-S of 16" diameter and a depth of 8 inches (Figure C.7).

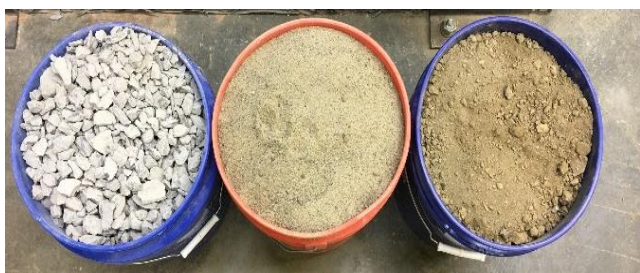

(a)

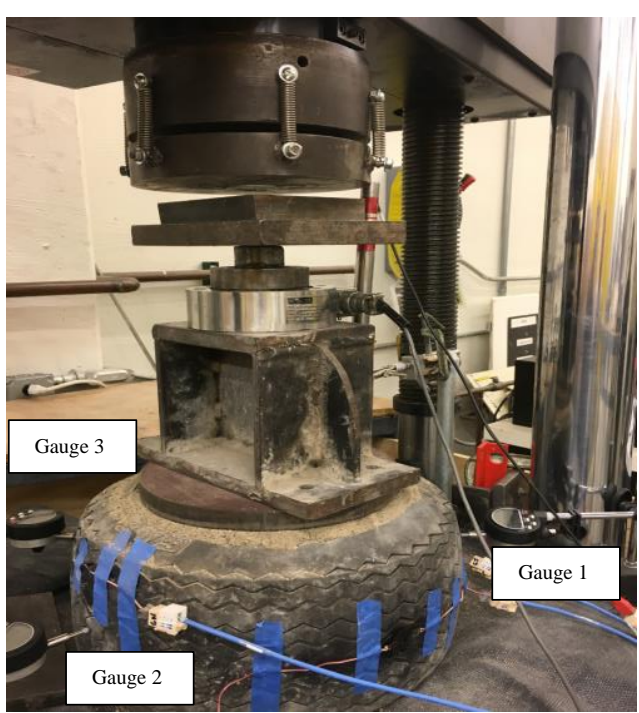

(b)

Figure C. 7 Confinement data acquisition (a) tested infill materials (AASHTO \#57 aggregate, sand, SM-soil) (b) set-up to obtain micro-confinement data 
Loads were applied vertically on the instrumented TDGC with different infill materials. Three dial gauges were placed around the circumference to measure the lateral displacement.

The data discussed in the following section corresponds to the displacement values obtained at peak load conditions for each material and they are as follows: AASHTO \#57 aggregate (20 kip), sand (15 kip), and SM-soil (10 kip). Diameter of the TDGC-S is 16" with a vertical depth of 8 ".

\section{$\underline{\text { AASHTO \#57 Aggregate }}$}

Displacements fo AASHTO \#57 aggregate were recorded in three independent load cycles. Tables C. 2 thru C. 4 reflect lateral and vertical displacement values recorded at a $20 \mathrm{kip}$ load. Strain in the X-direction (hoop) $\left(\varepsilon_{\mathrm{x}}\right)$ was calculated by multiplying the averaged horizontal displacement per cycle by 2 to account for uniform average expansion of the TDGC-S, and then divided by the initial diameter of the TDGC-S (16 inches). Strain in the Z-direction $\left(\varepsilon_{\mathrm{z}}\right)$ was calculated by dividing the vertical displacement by the itnitial depth of the TDGC-S, 8 inches. Three cycles of loading were conducted independently. Note, with each load cycle, small residual displacements were noted.

Table C. 2 Horizontal displacement of the TDGC-S when filled with (AASHTO \#57) coarse aggregate

\begin{tabular}{|c|c|c|c|}
\hline \multicolumn{4}{|c|}{ X-direction (hoop) } \\
\hline \multirow{3}{*}{$\begin{array}{c}\text { Gauge } \\
\text { Number }\end{array}$} & $\begin{array}{c}\text { Load } \\
\text { Cycle }\end{array}$ & $\begin{array}{c}\text { Infill } \\
\text { Material }\end{array}$ & $\begin{array}{c}\text { Horizontal } \\
\text { Displacement (in) }\end{array}$ \\
\hline \multirow{4}{*}{1} & 1 & Aggregate & 0.434 \\
\cline { 2 - 4 } & 2 & Aggregate & 0.235 \\
\cline { 2 - 4 } & 3 & Aggregate & 0.179 \\
\hline \multirow{3}{*}{2} & 1 & Aggregate & 0.441 \\
\cline { 2 - 4 } & 2 & Aggregate & 0.262 \\
\cline { 2 - 4 } & 3 & Aggregate & 0.203 \\
\hline \multirow{3}{*}{3} & 1 & Aggregate & 0.381 \\
\cline { 2 - 4 } & 2 & Aggregate & 0.351 \\
\cline { 2 - 4 } & 3 & Aggregate & 0.200 \\
\hline
\end{tabular}


Table C. 3 Strain calculation in the X-direction (hoop) from vertically applied loads to the aggregate within the TDGC-S

\begin{tabular}{|c|c|c|c|c|}
\hline $\begin{array}{c}\text { Load } \\
\text { Cycle }\end{array}$ & $\begin{array}{c}\text { Average Horizontal } \\
\text { Displacement (in) }\end{array}$ & $\begin{array}{c}\text { TDGC } \\
\text { Displacement (in) }\end{array}$ & $\begin{array}{c}\text { Initial } \\
\text { Diameter (in) }\end{array}$ & $\boldsymbol{\varepsilon}_{\mathbf{x}}$ \\
\hline 1 & 0.419 & 0.837 & 16 & 0.0523 \\
\hline 2 & 0.283 & 0.565 & 16 & 0.0353 \\
\hline 3 & 0.194 & 0.388 & 16 & 0.0243 \\
\hline
\end{tabular}

Table C. 4 Calculation for strain observed in the Z-direction (axial) with aggregate infill for a TDGC-S

\begin{tabular}{|c|c|c|c|}
\hline \multicolumn{4}{|c|}{ Z-direction (axial) } \\
\hline $\begin{array}{c}\text { Load } \\
\text { Cycle }\end{array}$ & $\begin{array}{c}\text { Vertical } \\
\text { Displacement (in) }\end{array}$ & $\begin{array}{c}\text { Depth of } \\
\text { Cell (in) }\end{array}$ & $\boldsymbol{\varepsilon}_{\mathbf{z}}$ \\
\hline 1 & 1.641 & 8 & 0.205 \\
\hline 2 & 1.1522 & 8 & 0.144 \\
\hline 3 & 0.826 & 8 & 0.103 \\
\hline
\end{tabular}

$\underline{\text { Sand }}$

Displacement for sand infill was recorded in three independent load cycles. Tables C.5 thru C.7 reflect displacement values recorded at $15 \mathrm{kip}$ in reference to lateral and vertical displacement. The same approach was used to measure strains in the X-direction and Y-direction. Two cycles of loading the sand were conducted for this specimen as it compacted more significantly during the load application. Note, with each load cycle, small residual displacements were noted. 
Table C. 5 Horizontal displacement of the TDGC-S when filled with sand

\begin{tabular}{|c|c|c|c|}
\hline \multicolumn{4}{|c|}{ X-direction (hoop) } \\
\hline \multirow{2}{*}{$\begin{array}{c}\text { Gauge } \\
\text { Number }\end{array}$} & $\begin{array}{c}\text { Load } \\
\text { Cycle }\end{array}$ & $\begin{array}{c}\text { Infill } \\
\text { Material }\end{array}$ & $\begin{array}{c}\text { Horizontal } \\
\text { Displacement (in) }\end{array}$ \\
\hline \multirow{2}{*}{1} & 1 & Sand & 0.372 \\
\cline { 2 - 4 } & 2 & Sand & 0.128 \\
\hline \multirow{2}{*}{2} & 1 & Sand & 0.342 \\
\cline { 2 - 4 } & 2 & Sand & 0.123 \\
\hline \multirow{2}{*}{3} & 1 & Sand & 0.310 \\
\cline { 2 - 4 } & 2 & Sand & 0.181 \\
\hline
\end{tabular}

Table C. 6 Strain calculation in the X-direction (hoop) from vertically applied loads to the sand within the TDGC-S

\begin{tabular}{|c|c|c|c|c|}
\hline $\begin{array}{c}\text { Load } \\
\text { Cycle }\end{array}$ & $\begin{array}{c}\text { Average Horizontal } \\
\text { Displacement (in) }\end{array}$ & $\begin{array}{c}\text { TDGC } \\
\text { Displacement (in) }\end{array}$ & $\begin{array}{c}\text { Initial } \\
\text { Diameter (in) }\end{array}$ & $\boldsymbol{\varepsilon}_{\mathbf{x}}$ \\
\hline 1 & 0.341 & 0.683 & 16 & 0.0427 \\
\hline 2 & 0.144 & 0.288 & 16 & 0.0180 \\
\hline
\end{tabular}

Table C. 7 Calculation for strain observed in the Z-direction (axial) with sand infill for a TDGC-S

\begin{tabular}{|c|c|c|c|}
\hline \multicolumn{4}{|c|}{ Z-direction (axial) } \\
\hline $\begin{array}{c}\text { Load } \\
\text { Cycle }\end{array}$ & $\begin{array}{c}\text { Vertical } \\
\text { Displacement (in) }\end{array}$ & $\begin{array}{c}\text { Depth of } \\
\text { Cell (in) }\end{array}$ & $\boldsymbol{\varepsilon}_{\boldsymbol{z}}$ \\
\hline 1 & 1.616 & 8 & 0.202 \\
\hline 2 & 0.760 & 8 & 0.095 \\
\hline
\end{tabular}


$\underline{\text { SM-Soil }}$

Tables C.8 thru C.10 reflect values recorded at 10 kip in reference to lateral and vertical displacement. Two cycles of loading were conducted, just just similar to sand.

Significant confinement of the SM-soil was observed during testing. Note, with each load cycle, small residual displacements were noted.

Table C. 8 Horizontal displacement of the TDGC-S when filled with SM-soil

\begin{tabular}{|c|c|c|c|}
\hline \multicolumn{4}{|c|}{ X-direction (hoop) } \\
\hline \multirow{2}{*}{$\begin{array}{c}\text { Gauge } \\
\text { Number }\end{array}$} & $\begin{array}{c}\text { Load } \\
\text { Cycle }\end{array}$ & Specimen & $\begin{array}{c}\text { Horizontal } \\
\text { Displacement (in) }\end{array}$ \\
\hline \multirow{2}{*}{1} & 1 & SM-Soil & 0.300 \\
\cline { 2 - 4 } & 2 & SM-Soil & 0.0324 \\
\hline \multirow{2}{*}{2} & 1 & SM-Soil & 0.262 \\
\cline { 2 - 4 } & 2 & SM-Soil & 0.014 \\
\hline \multirow{2}{*}{3} & 1 & SM-Soil & 0.184 \\
\cline { 2 - 4 } & 2 & SM-Soil & 0.038 \\
\hline
\end{tabular}

Table C. 9 Strain calculation in the X-direction (hoop) from vertically applied loads to the SMsoil within the TDGC-S

\begin{tabular}{|c|c|c|c|c|}
\hline $\begin{array}{c}\text { Load } \\
\text { Cycle }\end{array}$ & $\begin{array}{c}\text { Average Horizontal } \\
\text { Displacement (in) }\end{array}$ & $\begin{array}{c}\text { TDGC } \\
\text { Displacement (in) }\end{array}$ & $\begin{array}{c}\text { Initial } \\
\text { Diameter (in) }\end{array}$ & $\boldsymbol{\varepsilon}_{\mathbf{x}}$ \\
\hline 1 & 0.249 & 0.497 & 16 & 0.0311 \\
\hline 2 & 0.028 & 0.056 & 16 & 0.0035 \\
\hline
\end{tabular}

Table C. 10 Calculation for strain observed in the Z-direction (axial) with SM-soil infill for a TDGC-S

\begin{tabular}{|c|c|c|c|}
\hline \multicolumn{4}{|c|}{ Z-direction (axial) } \\
\hline $\begin{array}{l}\text { Load } \\
\text { Cycle }\end{array}$ & $\begin{array}{c}\text { Vertical } \\
\text { Displacement (in) }\end{array}$ & $\begin{array}{c}\text { Depth of } \\
\text { Cell (in) }\end{array}$ & $\boldsymbol{\varepsilon}_{\mathbf{z}}$ \\
\hline 1 & 2.290 & 8 & 0.286 \\
\hline 2 & 0.300 & 8 & 0.038 \\
\hline
\end{tabular}


Summary of Poisson's Ratio Calulations for AASHTO \#57 aggregate, sand, and SM-soil infill

The summary table provided below displays the poisson's ratios for each infill material per cycle. The poisson's ratio values have been averaged (Avg.) per each independent cycle.

Table C. 11 Summary of Poisson's ratios for AASHTO \#57 aggregate, sand, and soil confined by a TDGC-S

\begin{tabular}{|c|c|c|c|c|c|c|c|c|c|}
\cline { 2 - 10 } \multicolumn{1}{c|}{} & \multicolumn{3}{c|}{$\begin{array}{c}\text { AASHTO \#57 } \\
\text { Aggregate }\end{array}$} & \multicolumn{4}{c|}{ Sand } & \multicolumn{3}{c|}{ SM-soil } \\
\hline $\begin{array}{c}\text { Load } \\
\text { Cycle }\end{array}$ & $\boldsymbol{\varepsilon}_{\mathbf{x}}$ & $\boldsymbol{\varepsilon}_{\mathbf{z}}$ & $\begin{array}{l}\text { Poisson's } \\
\text { Ratio (v) }\end{array}$ & $\boldsymbol{\varepsilon}_{\mathbf{x}}$ & $\boldsymbol{\varepsilon}_{\mathbf{z}}$ & $\begin{array}{l}\text { Poisson's } \\
\text { Ratio (v) }\end{array}$ & $\boldsymbol{\varepsilon}_{\mathbf{x}}$ & $\boldsymbol{\varepsilon}_{\mathbf{z}}$ & $\begin{array}{c}\text { Poisson's } \\
\text { Ratio (v) }\end{array}$ \\
\hline 1 & 0.052 & 0.205 & 0.255 & 0.043 & 0.202 & 0.211 & 0.031 & 0.286 & 0.109 \\
\hline 2 & 0.035 & 0.144 & 0.245 & 0.018 & 0.095 & 0.189 & 0.004 & 0.038 & 0.094 \\
\hline 3 & 0.024 & 0.103 & 0.235 & - & - & - & - & - & - \\
\hline Avg. & & & $\mathbf{0 . 2 4 5}$ & & & $\mathbf{0 . 2 0 0}$ & & & $\mathbf{0 . 1 0 1}$ \\
\hline $\begin{array}{c}\text { Noted } \\
\text { Values }\end{array}$ & & & $\begin{array}{c}\mathbf{0 . 3 0} \\
\text { (Tang,2011) }\end{array}$ & & & $\begin{array}{c}\mathbf{0 . 3 0 - 0 . 3 5} \\
\text { (Maher,2008 }\end{array}$ & & & $\begin{array}{c}\mathbf{0 . 3 0} \\
\text { (Maher,2008) }\end{array}$ \\
\hline
\end{tabular}

\section{C.2.3 Vertical and Horizontal Displacement Comparisons for AASHTO \#57 Aggregate, Sand, and SM-soil}

Examining the vertical and horizontal displacements at specific load levels, comparisons can be made for effectiveness of confinement with AASHTO \#57 aggregate, sand, and SM-soil specimens. The final load cycle for each infill material was utilized for comparisons of displacement at loads of $10 \mathrm{kip}$ and 15 kip. Figure C.8 shows the vertical and horizontal displacements at 10 kips for AASHTO \#57 aggregates, sand, and SM-soil. 


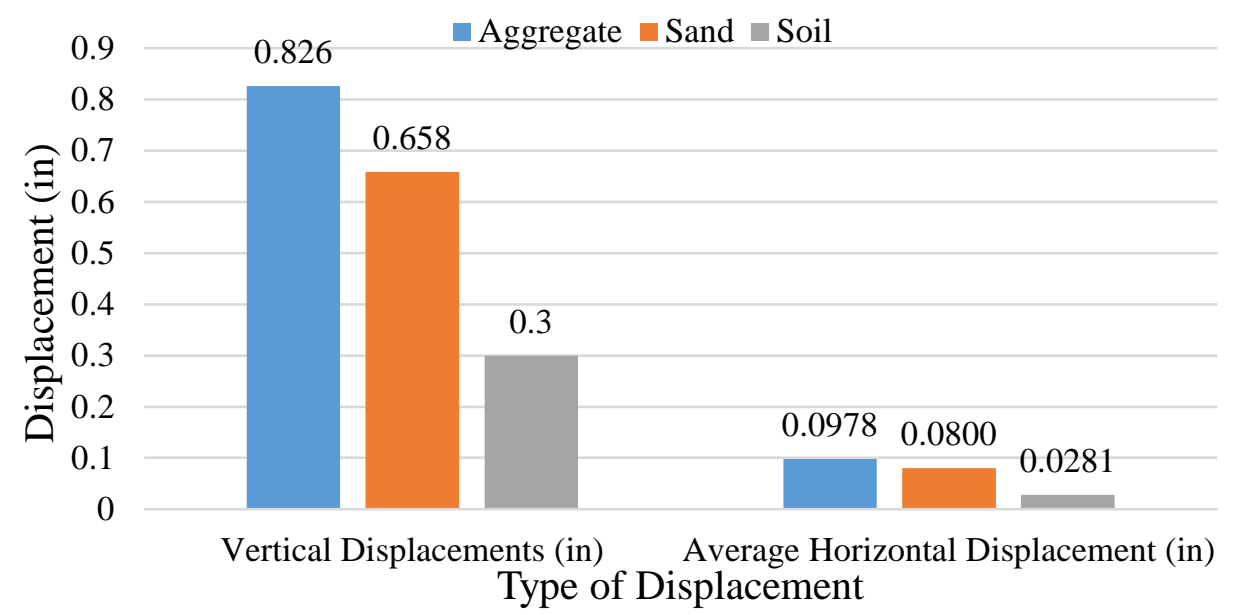

Figure C. 8 Vertical and horizontal displacements in the final load cycle for each infill material at 10 kips of load

By examining the data, it was observed that the average ratios of vertical displacement to horizontal displacement was very similar for each material as shown in Table C.12. Displacement was higher in the vertical and lateral direction for AASHTO \#57 aggregate which suggests even at 10 kips of load the specimen had not reached a critical compaction level such as that of the SMsoil; however, it should be noted that the aggregates are surrounded outside of the TDGC in the real field application, and the compaction that can be achieved is significantly less. The SM-soil displaced less vertically and horizontally after two cycles of 10 kip loading. The dissipation of displacements for the SM-soil suggests that it was well compacted within the TDGC. Figure C.9 shows the confinement effects of the TDGC-S on the SM-soil specimen. The figure shows how the soil was confined after experiencing 10 kips of load after two cycles of loading. The TDGC was tilted to facilitate the removal of the SM-soil specimen. The SM-soil was tightly compacted after displacing 2.290 inches (refer to Table C.10) and the removal was very difficult. The soil's ability to adhere to the confining walls of the TDGC-S made the SM-soil strong and achieve a higher degree of compaction which leads to improved load bearing capacity. 


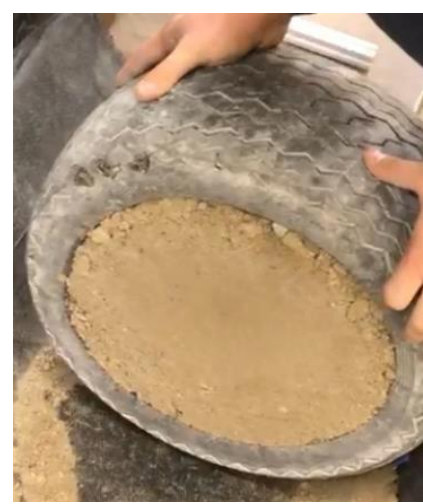

(a)

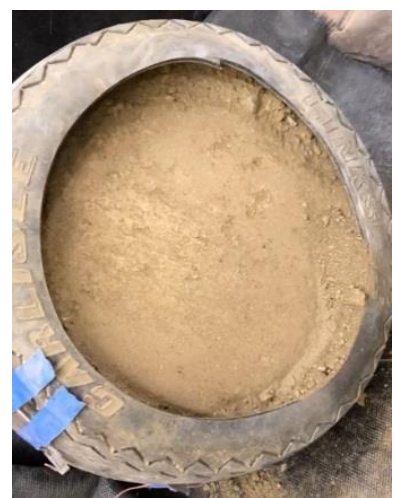

(b)

Figure C. 9 SM-soil compacted following $10 \mathrm{kip} \mathrm{load} \mathrm{(a)} \mathrm{TDGC-S} \mathrm{tilted} \mathrm{vertically} \mathrm{following}$ two cycles of 10 kips (b) displays the displacement within the TDGC-S

Table C. 12 Vertical to horizontal displacement ratios at 10 kip

\begin{tabular}{|c|c|c|c|}
\hline $\begin{array}{c}\text { Infill } \\
\text { Material }\end{array}$ & $\begin{array}{c}\text { Vertical (axial) } \\
\text { Displacement (in) }\end{array}$ & $\begin{array}{c}\text { Average Horizontal } \\
\text { (hoop) } \\
\text { Displacement (in) }\end{array}$ & Ratio \\
\hline $\begin{array}{c}\text { AASHTO \#57 } \\
\text { Aggregate }\end{array}$ & 0.826 & 0.0978 & 0.118 \\
\hline Sand & 0.658 & 0.0800 & 0.122 \\
\hline SM-Soil & 0.300 & 0.0281 & 0.094 \\
\hline \multicolumn{2}{|r|}{} & Average & $\mathbf{0 . 1 1 1}$ \\
\cline { 3 - 4 }
\end{tabular}

To further support congruency in vertical to horizontal displacement, data was obtained for the AASHTO \#57 aggregate and the sand at a load of 15 kips in each specimen's final cycle. Data is provided in Figure C.10.

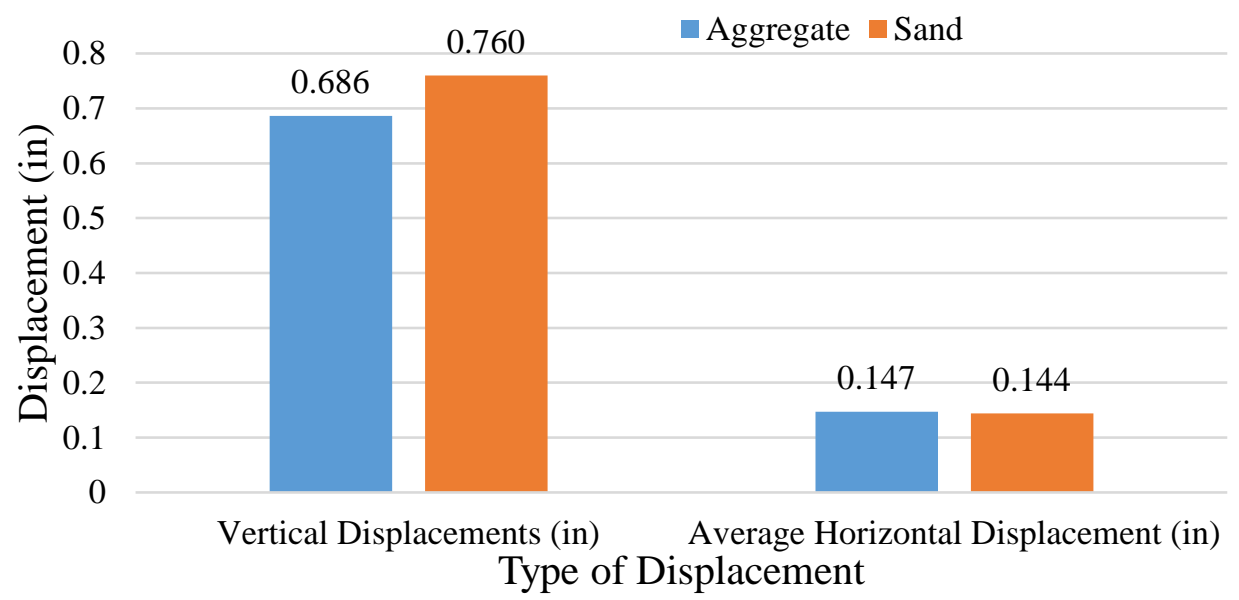

Figure C. 10 Vertical and horizontal displacements in the final trial for each specimen at 10 kips of load 
The displacement trend for each infill material at 15 kips of load was very similar even though the sand had a slightly larger vertical displacement when compared to that of the AASHTO \#57 aggregate. Table C.13 provides data obtained from the final load cycle for each specimen at 15 kips of load. Soil is not listed as it was loaded to 10 kips.

Table C. 13 Vertical to horizontal displacement ratios at 15 kip

\begin{tabular}{|c|c|c|c|}
\hline $\begin{array}{c}\text { Infill } \\
\text { Material }\end{array}$ & $\begin{array}{c}\text { Vertical } \\
\text { Displacement (in) }\end{array}$ & $\begin{array}{c}\text { Average Horizontal } \\
\text { Displacement (in) }\end{array}$ & Ratio \\
\hline $\begin{array}{c}\text { AASHTO \#57 } \\
\text { Aggregate }\end{array}$ & 0.686 & 0.147 & 0.214 \\
\hline Sand & 0.76 & 0.1440 & 0.189 \\
\hline SM- Soil & - & - & - \\
\hline \multicolumn{2}{|r}{} & Average & $\mathbf{0 . 2 0 2}$ \\
\cline { 2 - 4 }
\end{tabular}

\section{C.2.4 Instrumented Confinement Test Conclusions}

Applying vertical load within the TDGC-S similar displacement values were obtained pertaining to each infill material (AASHTO \#57 Aggregate, sand, and soil). By analyzing the displacements in the X-direction (hoop) and Z-direction (axial), a relationship for Poisson's ratio was determined for each infill material. Values were averaged for each load cycle, and the Poisson's ratios of 0.245 (AASHTO \#57 aggregate), 0.200 (sand), and 0.101 (SM-soil) were calculated. Poisson's ratios for some of the common materials include 0.15 (concrete), 0.35 (hotmix asphalt), cement-treated granular fills (0.15), lime-fly-ash mixtures (0.15), dense sand (0.35), AASHTO \#57 aggregate (Tang, 2011), and silty sand/ loose sand (0.30) (Maher, 2008). The average values of Poisson's ratio for each of the confined infill materials is much lower than the typical ranges found for the unconfined infill materials. The data also suggests that during field installation, some compaction measures may be helpful. However, this aspect needs to be further investigated because the field installation will have multiple geowebs or TDGCs that are covered with infill material outside of their material walls and higher levels of confinement effects may be present than those evaluated in this study. The Poisson's ratio for unconfined and TDGC confined AASHTO \#57 aggregate, sand, and SM-soil (silty sand) are (0.30 vs. 0.245), (0.30-0.35 vs. 0.20), and $(0.30$ vs 0.101$)$, respectively. The reduced Poisson's ratio shows the effectiveness of confinement by the TDGC. 